\title{
LOD DOCUMANACION DE SEFMICIOS
}

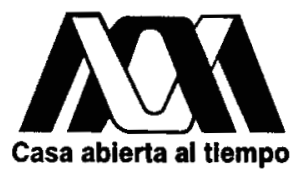

\section{1}

\section{UNIVERSIDAD AUTONOMA METROPOLITANA UNIDAD IZTAPALAPA \\ DIVISION DE CIENCIAS SOCIALES Y HUMANIDADES \\ DEPARTAMENTO DE ANTROPOLOGIA}

\section{RITMO y ESTRUCTURA DEL CICLO RITUAL YAQUI}

María Eugenia Olavarría Patiño

Tesis de Doctorado en Ciencias Antropológicas

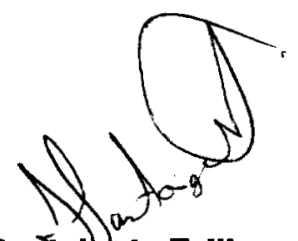

Director: Dr. Juan Castaingts Teillery Asesor: Dr. Gilberto Giménez Montiel Asesor: Adrián S.Gimate - Welsh H.

México, D.F. 
Dios emchi ouhtesia

A Martín y Angélica

Ingrid, Eleno, Odile, Alejandro

In memoriam 


\section{RITMO y ESTRUCTURA DEL CICLO RITUAL YAQUI}

Introducción

4

\section{Preguntas y Paradigmas}

Cinco modelos antropológicos....................... 11

Los tres vértices del triángulo........................ 29

\section{La construcción de una etnia}

El territorio. Signo metonímico de la identidad........... 42

Primer momento $1525-1767 \ldots \ldots \ldots \ldots \ldots . .48$

Segundo momento $1767-1936 \ldots \ldots \ldots \ldots . . .52$

Tercer momento 1936-1997................ 55

Símbolos de la identidad.............................. 65

Una frontera viviente............................... 76

\section{La unidad espacio temporal del ciclo}

Sintaxis de la dimensión espacio temporal............. 81

Límites simbólicos....................... 83

Tebat, iglesia y altar..................... 94

¿Qué es un pahko?................................ 99 


\section{Etnografía de un año ritual}

Principios sintácticos del ciclo............................. 108

Tiempo ordinario.................................. 117

Wasuktia. Ritos del santoral..................... 118

Ciclo de lluvias............................ 118

Fiestas patronales....................... 123

Fiestas de carácter doméstico............. 130

Ritos de paso..................................... 131

Ciclo de vida................................... 133

Confirmaciones.............................. 134

Cuaresma............................................ 139

Miércoles de Ceniza y Viernes de Cuaresma..... 139

Tinieblah...................................... 148

Última Cena y la correteada del viejito........... 152

Viemes Santo.................................. 156

Sábado de Gloria y Domingo de Resurrección.... 159

Transposiciones estacionales: incesto imaginario............ 165

\section{Sistema cosmológico}

Principios narrativos del ciclo ritual....................... 182

Estructura sintáctica................................... 195

Incesto simbólico: los eclipses .......................... 205

\section{Sistema de los actores rituales}

Parentesco, parentesco ritual y rituales laicos............... 216

Etnografía de los ya'uram .................................... 228

Sintaxis de las relaciones rituales......................... 232

Cruces y flores ...................................... 239

Conclusión ............................................... $\quad 248$

Bibliografía................................................. 256 


\section{INTRODUCCIÓN}

La interpretación del ciclo ritual yaqui, y la especificidad del sistema cultural que de él se deriva, es el principal propósito de este trabajo. Para alcanzar este fin, la investigación se despliega hacia dos direcciones, una de ellas, la reconstrucción de una cosmología con base en el registro etnográfico; la otra, hacia los dispositivos teóricos que permiten su comprensión.

En cuanto a la perspectiva etnográfica, parto del reconocimiento de la sociedad yaqui contemporánea como una confluencia de poderosas corrientes de distinta profundidad histórica: el legado tradicional anterior al contacto colonial, la intensa huella originada por el catolicismo jesuita de los siglos XVII y XVIII, sumados a una convivencia atribulada, desigual y violenta de cinco siglos de persistencia con las poblaciones criollas y mestizas y sus respectivos gobernantes. La cultura yaqui es, en cuanto cultura, un metasistema y en cuanto construcción históricamente determinada, el resultado de un proceso de comunicación -interacción-de varias tradiciones y visiones del mundo que, al entrecruzarse, generan un campo de coincidencias e intersticios que constituyen el objeto de mi interés.

En este sentido, mi investigación propone dar cuenta de la especificidad y originalidad del sistema cultural yaqui, en virtud de que las respuestas encontradas en la literatura sobre esta etnia plantean la necesidad de asumir ese reto. Sin pretender negar los avances etnográficos e interpretativos que en esta materia han alcanzado los estudios sobre los yoremes, las conclusiones a que arriban parecen oscilar entre dos polos, uno de ellos representado por las caracterizaciones como grupo étnico persistente y de estilo apolíneo (Spicer 1994, Figueroa 1994) y aquellas afirmaciones que enfatizan su capacidad creativa y más bien adaptable (Gouy-Gilbert 1983). Ambos tipos de afirmaciones son ciertos pero parciales; mi perspectiva se funda en una convicción de totalidad basada en la reconstrucción etnográfica, del que concibo como uno de los códigos dominantes de esta cultura, su ciclo anual de actividad ritual.

Las bases para el conocimiento sobre la vida ritual cíclica anual en las comunidades yaquis las proporcionan, por un lado, mis estudios sobre la mitología de los pueblos indigenas del Noroeste de México y de los yaquis, 
que llevé a cabo desde 1984', los cuales constituyeron la base para realizar dos investigaciones de campo más, entre 1988 y 1989, en los poblados de Pótam, Vícam Estación, Vícam Pueblo, Tórim, Loma de Guamúchil, Las Guásimas y Aguacaliente; el primero individualmente (mayo - julio 1988) y el segundo (de octubre de 1988 a febrero de 1989) coordinando un equipo de cinco estudiantes del Departamento de Antroplogía de la UAM - Iztapalapa.

El libro de carácter etnográfico publicado en $1992^{2}$ así como las síntesis monográficas de $1995^{3}$, pueden considerarse productos de esas investigaciones. Paralelamente, he desarrollado una investigación teórica cuyos resultados son varios artículos publicados entre 1989 y $1997^{4}$.

A partir de 1995, reanudé el trabajo de campo con varias estancias en las comunidades de Vícam Pueblo, Las Guásimas y Loma de Guamúchil hasta

${ }^{1}$ Cuyos resultados son los artículos: "La mitología cosmogónica del Occidente de México" y "La mitología cosmogónica del Noroeste" publicados en Jesús Monjarás-Ruiz coordinador, Mitos cosmogónicos del México indigena, Instituto Nacional de Antropología e Historia, Colección Biblioteca México, 1987, págs. 209-305 (primera reimpresión 1989); y el libro Análisis estructural de la mitologia yaqui, Instituto Nacional de Antropología e Historia - Universidad Autónoma Metropolitana, Colección científica, México, 1989, (primera reimpresión 1990).

2 María Eugenia Olavarría, Simbolos del desierto, Universidad Autónoma Metropolitana, Colección Texto y Contexto núm.10, México, 1992

3 En inglés: "Yaqui", Encyclopedia of World Cultures, vol. VIII Middle America and the Caribbean, G.K. Hall \& Co., Boston, Massachusetts, 1995, págs. 305-308. En español "Los yaquis", Etnografia Contemporánea de México, Volumen I Región Noroeste, Instituto Nacional Indigenista, México, 1995 págs. $531-573$ y Yaquis, Colección Pueblos Indígenas de México, Instituto Nacional Indigenista, México, 1995, 22 p.

4 "Lo numinoso: mito y terror", Alteridades. Anuario de Antropologia, UAM, México, 1989, págs. 113-121; "Mito, magia, religión" en Ricardo Avila Palafox comp., Jornadas de antropología, Universidad de Guadalajara, México, 1989, págs. 143-157; "Ruidos en el bosque", Galeras, Fondo de Cultura Económica, México, 1991; "La noche diurna. mitologia de los eclipses" en Jesús Jáuregui, María Eugenia Olavarría y Víctor Franco coords., Cultura y comunicación. Edmund Leach in memoriam, UAM-CIESAS , 1996, págs. 273-287; "Origen y destino en el discurso mítico", Discursos y mitos. Algunas aproximaciones, Departamento de Filosofia, UAM, 1996; y "El pensamiento salvaje y la importancia de ser imperfecto", Alteridades. Símbolos, experiencias, rituales, UAM, año 7 , núm. 13, 1997, págs. 33-38. 
1997, de manera que esta tesis se basa en los registros de ambos períodos y presenta etnografia inédita en lo referente a la reconstrucción, fecha por fecha del calendario ritual, el sistema de parentesco y parentesco ritual, sobre los registros vestimentarios e iconográficos y en los aspectos contemporáneos relevantes.

En términos generales, esta tesis se apoya en los estudios previos mencionados, pero en algunos casos los completa y, en otros, los corrige. El estudio de la mitología que representó mi punto de atención primario fue desplazado hacia los ritos, en la medida en que observé cómo mitos recopilados en la primera mitad del siglo por etnógrafos como Alfonso Fabila, gracias a su difusión a través del sistema educativo bilingüe indigena o por conocimiento directo, habian llegado, de nueva cuenta, a formar parte del acervo familiar. La "Leyenda yaqui de las predicciones" (Fabila 1978) se narra hoy día frente al televisor, pero no como mensaje proveniente de la cadena tradicional oral, sino como un aprendizaje más que, sobre todo los más jóvenes, han retomado de un medio escrito, y lo mismo ocurre con otros relatos.

Frente a esto, la vida ritual no ha perdido su fuerza. Con ello no quiero decir que no se haya modificado; sin embargo, el tiempo y energía que dedican a la actividad ritual son relevantes en todo sentido, hecho reconocido por la mayoría de los antropólogos, lo que convierte a los pobladores de los ocho pueblos yaquis en un ejemplo privilegiado de lo que Mary Douglas definió como código restricto o ritualismo: alta clasificación, control fuerte, creencia en que las relaciones personales deben subordinarse al esquema público de roles, sociedad diferenciada en roles externos e internos y ensalzada por encima del yo (Douglas 1978:99).

Entendido así, como un código o cuadrícula, el ciclo ritual articula distintos órdenes de la actividad humana y provee un marco clasificatorio para el grupo. De manera que descubrir los principios de dicha taxonomía ha sido uno de los primeros pasos que me permitió, en un momento dado, la identificación de los ciclos vitales, estacionales y todos aquellos campos relativos a su propia interpretación cultural e ideológica intrínseca a los procesos y actores sociales.

Los ritos que se describen son, a fin de cuentas, actividades que involucran a comunidades enteras diferenciadas internamente con sistemas y jerarquías establecidas de antemano, impregnadas de un conocimiento que los justifica y les da sentido. 
No resulta sencilla así, la reconstrucción de este conocimiento, puesto que, aunque en ella consiste justamente la tarea del intérprete antropólogo, ese saber no siempre está presente de manera explícita entre los mismos actores, y raras veces se encuentra en su totalidad en los individuos que conforman el universo cultural. De manera que el camino que lleva a tal reconocimiento parte de la identificación de una lógica basada preferentemente en signos. En efecto, se trata de un conjunto particular de lógicas en cuya especificidad radica un efecto de significación que la interpretación tiene por meta identificar. Paradójicamente, cuanto más se acerca esta mirada alejada de las representaciones originarias, más se aleja de la práctica del bricolage. $\mathrm{El}$ ejercicio de la interpretación etnológica, en la medida en que respeta la lógica de lo concreto, fabrica otra, ya no basada en signos, sino en conceptos, que no deja de expresarse semióticamente. Esta nueva lógica que consiste en el sistema de categorizaciones y nociones de los antropólogos, posee también una dimensión de objeto simbólico pero de un nuevo orden, en tanto que "cuando se confrontan dos sistemas simbólicos, éstos comienzan a formar un todo aún en razón de su oposición" (Douglas 1978:60)

Visto de esta manera, la respuesta a mi planteamiento no puede ser sino un desarrollo dirigido hacia la articulación, en un nuevo conjunto, del mito, el rito, el parentesco y los registros espaciales y plásticos. Dichos lenguajes se presentan así, como distintas expresiones de un principio más general, la articulación en torno a la repetición y la narratividad, base del discurso mítico (Leroi-Gourhan 1971).

En este sentido, mi perspectiva interpretativa se sitúa también en un punto intersticial, las nociones de ritmo (movimiento en un tiempo y espacio determinados) y estructura (la forma vista desde dentro) combinan dos visiones a menudo concebidas como separadas. La noción de ritmo está más del lado del ethos de la cultura, es afin a las dimensiones estilísticas; por su parte, el concepto de estructura apela a principios cognitivos ordenadores propios de la visión del mundo. Ambas dimensiones son, más que otra cosa, producto del énfasis puesto por el observador (Ortner 1993:14).

El abanico de autores en cuyo trabajo teórico me apoyo, deja sentir su peso diferencial en cada uno de los capítulos que conforman esta tesis. El primer capítulo está dedicado a la exposición de lo que constituye, desde mi punto de vista, un momento crítico de la discusión contemporánea alrededor de la interpretación de los procesos simbólicos. Hago referencia a los autores 
clásicos y a otros cuya lectura inspiró la formulación de las nuevas preguntas que conforman, en conjunto, mi punto de vista teórico y metodológico.

El segundo capítulo tiene por objeto delinear la identidad del grupo yaqui como un proceso de construcción que abarca dos dimensiones: la primera de ellas se refiere a los mecanismos históricos con base en los cuales se construyó el signo metonímico por excelencia: el territorio. La segunda dimensión mantiene una perspectiva sincrónica y está centrada en el reconocimiento de las diferentes representaciones, metafóricas, de la identidad. Veo este proceso en lo fundamental, como un ejemplo de lo que Bourdieu (1984) designa como la lucha por las clasificaciones, es decir, de qué manera la sociedad yaqui ha llegado a ocupar un espacio, tanto físico como expresivo, en el contexto de la realidad nacional contemporánea.

El tercer capítulo está dedicado a la definición del objeto de análisis: la unidad espacio - temporal constituida por la fiesta. Intento demostrar cómo, al unir un conjunto de categorías espaciales mediante un movimiento realizado en el tiempo, el rito es indicativo de un principio estilístico. En primer término, el análisis del paisaje así concebido se basa en la metodología de Leroi-Gourhan (1971) y Galarza (1979), así como en los desarrollos de la geografia cultural (Bouchard 1994). La segunda parte del capítulo tercero es la descripción de una fiesta representativa y la identificación de sus componentes, el cual sirve como puente para su ulterior presentación en una ordenación sucesiva y cíclica.

Este ordenamiento coincide con el objeto del capítulo cuarto, el cual contiene la reconstrucción, fecha a fecha, del calendario ritual. La perspectiva unitaria que lo rige permite dar cuenta, con una mayor economía, de la naturaleza de los dos períodos estacionales: la cuaresma y el tiempo ordinario, y de los dos tipos de conjuntos rituales emparentados, los ritos de paso (individuales) y la conmemoración (colectiva) de los mismos.

Este conocimiento me permite proponer, en el capítulo quinto, un modelo cosmológico resultado del análisis narrativo (Grupo de Entrevernes 1982); y en el sexto, cómo este esquema es coherente para los actores rituales y cómo opera mediante categorías que atañen a la clasificación primaria del grupo social y del individuo: aquélla que divide a los parientes en prohibidos y permitidos (Durkhéim y Mauss 1963).

Como colofón de cada uno de los capítulos cuarto, quinto y sexto, presento una reflexión en torno a las intersecciones lógicas de cada nivel, para finalizar 
en la respuesta què el registro vestimentario, verdadero soporte de iconos y principios cromáticos, proporciona frente a la pregunta ¿por qué y cómo en el sistema yaqui se unen las flores y las cruces? 
PREGUNTAS Y PARADIGMAS 


\section{CINCO MODELOS ANTROPOLÓGICOS}

¿Cuáles son las respuestas de una comunidad, en la que conviven diversas tradiciones, sobre la organización de su mundo? ¿De qué manera el devenir espacio - temporal de un pueblo se encuentra inscrito en sus textos? ¿Qué tipo de relación mantienen los textos tradicionales y los no tradicionales? ¿A qué naturaleza de discurso remite la vida ritual? La respuesta a estas preguntas depende, a su vez, de otras, de naturaleza teórica ¿Cuál es la especificidad del conocimiento científico frente a las formas de conocimiento mítico, mágico, o no domesticado? ¿Es posible delinear los límites entre ciencia, mito y arte, en una formación cultural?

La presentación y discusión de los modelos formulados desde el discurso de los paradigmas antropológicos corresponde, por lo general, a un recuento crítico de la teoría o a una relación de autores agrupados en torno a un criterio clasificatorio (Sahlins 1987). El criterio cronológico, que aparece frecuentemente en este tipo de revisiones, presupone que las distintas aproximaciones se van superponiendo unas a otras, o bien su mutua refutación les permite alcanzar el estado en la que 'una' de ellas, se erige como, al menos, la 'más acabada' y obviamente será entonces la elegida por el investigador. El presupuesto implícito en esta perspectiva es que la "ciencia avanza", irremediablemente, hacia una sola dirección. No obstante, el mismo criterio cronológico, visto desde otro ángulo, permite la reconstrucción de un proceso complejo en el que mediante aproximaciones sucesivas y parciales se va desenvolviendo una trama de conceptos, metáforas, creencias y prejuicios que envuelve el paradigma o la episteme de un período (Foucault 1983).

La elección de un criterio conceptual presenta mayores ventajas, si se reconoce que la selección de uno u otro concepto particular representa en sí mismo una disección hasta cierto punto arbitraria. En este trabajo, no intento identificar un sólo concepto, sino la relación que los diversos paradigmas establecen entre dos cuerpos de conocimientos.

Estos paradigmas no se circunscriben a un autor, sino que consisten en modelos o esquemas comunes a conjuntos, en ocasiones pertenecientes a distintas tendencias o corrientes históricas del pensamiento antropológico. Los 
esquemas que se discuten aquí construyen su discurso en torno a la relación entre dos cuerpos de conocimiento: el cuerpo de conocimiento nombrado como 'científico, occidental, positivo, domesticado' y por otro lado, el denominado 'mentalidad primitiva, pensamiento prelógico, falsa conciencia, pensamiento mágico-religioso, mito, bricolage'.

E1 planteamiento de esta problemática es permanente, ya sea de manera explícita en el terreno de la discusión teórica y en la formulación de planteamientos de carácter general, o bien de manera tácita en las investigaciones etnográficas y etnológicas.

Dos autores - Tambiah (1990) y Schweder (1991) - podrían ilustrar paradigmáticamente cómo en trabajos recientes se plantean y discuten las posibilidades de la disciplina frente a cuestiones como la racionalidad, la inteligibilidad y la explicación de las culturas.

Para Stanley J. Tambiah la relación entre magia, religión y ciencia debe ser examinada en un marco histórico, en el que procesos como el judaísmo, la filosofía renacentista, la reforma protestante y la revolución industrial imprimen una huella determinante en el legado del discurso antropológico. Lo anterior le permite considerar las implicaciones y consecuencias sobre tres aproximaciones interpretativas: las teorías intelectualistas y evolutivas de Tylor (1903) y Frazer (1964), el funcionalismo malinowskiano y la distinción entre mentalidad lógica y mentalidad mística establecida por Lévy-Bruhl. Este acercamiento diacrónico no impide a Tambiah teorizar, desde un punto de vista sincrónico, sobre las derivaciones de cada una en lo que respecta a la conmesurabilidad, el relativismo y la traducción de las culturas.

Frente a esta percepción, hasta cierto punto determinista, Schweder propone una mirada relativista en la que -en términos del autor- el dominio del conocimiento de las culturas estaría en disputa por las bandas universalistas y evolutivistas del iluminismo frente a las de la rebelión romántica. Mientras las primeras atacan con las armas de la lógica, la estadística y la ciencia experimental; los románticos usan como escudo la expresividad, el simbolismo o la semiótica. Sobre el motivo de su enfrentamiento, este autor aclara que mientras los últimos se interesan primordialmente en las ideas noracionales (presupuestos, definiciones culturales, declaraciones, clasificaciones arbitrarias) y en sus modos verbales y no verbales de 
expresión, el iluminismo prefiere lo racional, las estructuras de conocimiento científicas y cuasi - científicas y los procesos intelectuales subyacentes.

Con esta perspectiva dicotómica, en mi opinión, se corre el riesgo de sucumbir ante el vértigo reduccionista, puesto que más de un autor puede resbalar en una zanja que no fue abierta para él. El mismo Schweder tambalea entre los dos cuerpos por él definidos como insolubles: primero, postula un enunciado iluminista como la distinción entre tres casos generales: lo irracional, lo racional y lo no - racional; enseguida se adentra en el postulado romántico de desarrollar una matriz de las interpretaciones lógicamente posibles de la diversidad cultural. A fin de cuentas, la clasificación universalista de Schweder no responde satisfactoriamente a su inquietud romántica.

Sin embargo, dado que mi interés corresponde al cómo, en el terreno de una cultura particular, se entrelazan lo racional, lo irracional y lo no - racional, debiera no sólo marcar la distancia frente a estos dos autores confrontados, sino también reconocer el valor interpretativo de sus propuestas.

En este sentido, si la imagen histórica provista por Tambiah permite reconocer la integración solidaria entre, por ejemplo, los intereses científico tecnológicos y el protestantismo - no sólo en la Inglaterra del siglo XVII sino en otros tiempos y lugares (Tambiah 1990:13) - luego es pertinente preguntarse, no sólo por los eventos extradisciplinarios que impresionan a la visión del mundo antropológico contemporáneo, sino igualmente por el carácter de largo alcance que algunas de estas visiones del mundo pueden tener. En Schweder está presente la intuición legítima de distinguir dos agrupamientos: el universalista y el romántico pero que, desde mi perspectiva, más que compartimentos, constituyen los dos polos entre los que oscila una variedad de posturas.

Mi propuesta intenta, en un sentido, recuperar la calidad histórica de largo alcance de los paradigmas, al tiempo que reconoce cinco modelos ubicados en un espectro, los cuales brindan respuestas en torno a la naturaleza de la relación entre los dos cuerpos de conocimiento referidos al inicio.

Los cinco esquemas corresponden a los tipos de relación construida en torno a las siguientes nociones: sucesión, heterogeneidad, insuficiencia, racionalidad y analogía. Estos esquemas ponen énfasis preferentemente en una de las 
nociones y a veces en otra, de manera complementaria. El presupuesto común a los cuatro primeros es el reconocimiento de la diferencia fundamental entre el 'pensamiento occidental' y el 'salvaje'.

El esquema que tiene como noción central la sucesión se apoya en dos enunciados en apariencia contradictorios; por un lado, confirma la humanidad de las poblaciones, en su tiempo calificadas como primitivas o ágrafas, al postular la unidad del espiritu humano (Morgan 1980). No obstante, al mismo tiempo, el evolucionismo enfatiza su desigualdad al segmentar a la misma humanidad - haciendo abstracción de tiempo y espacio - entre aquellas sociedades dominadas por el pensamiento mágico fetichista (periodo étnico del salvajismo) y por ello, consideradas inferiores respecto de los periodos étnicos superiores asociados a las religiones politeístas y monoteístas.

En la perspectiva del evolucionismo del XIX, el desarrollo de la humanidad está marcado por el progreso hacia un estadio 'positivo': magia y religión ocupan respectivamente las etapas anteriores e inferiores a la ciencia y su superación es la condición necesaria para el avance del conocimiento. Si bien al interior de esta concepción está considerada la posibilidad de involución, al menos por Frazer (1964), ésta se convierte en el inverso necesario a la fuerza del progreso. El esquema dominado por la idea de sucesión no sólo está presente en los etnólogos del XIX; algunas lecturas materialistas apuntan hacia esa dirección cuando afirman que la superación de la ideología será alcanzada en un tiempo en que las condiciones objetivas impongan a la ciencia como el único conocimiento cierto y verdadero. La finalidad implícita de predominio de los sistemas científicos sobre otras formas de conocimiento derivada de este esquema - se materializa en las transformaciones que traen consigo los procesos de occidentalización en el nivel intercultural, así como mediante la difusión de tecnologías.

Tal postura actúa en pos de la erradicación de los mitos, pero esconden otros tantos que interesa desvelar. Existe un conjunto de creencias en el sentido de que el papel de la ciencia consiste, entre otras cosas, en combatir las supersticiones. Lo que en parte coincide con lo que algunos científicos consideran que debe ser su función como difusores del conocimiento. 
En esta concepción, la ciencia se define por su antagonismo frente al pensamiento mágico, y la diferencia fundamental entre ambos sistemas estriba en que, en términos de capacidad predictiva, el primero es el acertado. La estrategia real y efectiva que sigue la ciencia permanece oculta para la mayoría del público, sin embargo, queda claro que la creencia en la magia es producto de la carencia o cuando menos de pobreza de cultura científica. Se deriva de esta postura: 1) que la creencia en la magia se remedia con una dosis de discurso científico; 2) que, a manera de fluidos, a mayor cantidad de la primera el segundo disminuye y a la inversa; 3) ambos sistemas pueden tener propiedades absolutas, como es la capacidad predictiva; y en consecuencia 4) la validez de ambos depende de su inserción en un sistema de creencias.

Es decir, en lugar de reconocer el error subsumido en el acto mágico real, se comete un acto mágico virtual análogo al triple "error" del hechicero de Leach: confunde símbolo metafórico (magia como metáfora de ignorancia 0 error) por signo metonímico $($ magia $=$ error), procede a tratar el signo imputado como si fuera un indicador natural (si se combate la magia se reduce el error), y finalmente interpreta el supuesto indicador natural como una señal capaz de desencadenar consecuencias automáticas a distancia "si combato la magia fortalece a la ciencia" (Leach 1976:42). No intento sugerir que las conferencias de difusión científica sean actos mágicos, sólo aplico la teoría antropológica tradicional de la magia a un fenómeno que, en su intención, es técnico y puede ser técnico en sus consecuencias, pero que en su forma real de acción resulta expresivo (ibidem).

Como contraparte, el caso de los afectados por el calificativo de ignorantes o científicos fallidos reproduce un juego análogo de lenguaje: al apresurarse a negar todo matiz supersticioso o fetichista a sus creencias y procurar demostrar por todos los medios que la suya es "la ciencia verdadera", basándose en una semejanza superficial frente a algunas ideas científicas occidentales, los magos perjuros reconocen implícitamente los presupuestos de sus detractores. El triple error invierte aquí sus términos: 1) la ciencia es metáfora de verdad (confunde símbolo metafórico), 2) la ciencia es la verdad (con signo metonímico), 3) estar fuera de la ciencia es estar contra la verdad (trata al signo como si fuera indicador natural), 4) si me asemejo a la ciencia me acerco a la verdad (y lo interpreta como una señal capaz de desencadenar consecuencias a distancia). 
Al evitar enfrentarse a los sistemas complejos y gramaticalizados como los rigurosamente científicos y optar por dialogar frente a otro muy distinto como el de las creencias generalizadas alrededor de la ciencia, esta nueva era de la magia se sitúa, también ella, dentro de los límites de las tradiciones populares.

La relación que intento establecer entre el esquema de sucesión y los actos mágico - expresivos descritos no es en absoluto de identidad, con ello ilustro los dos polos de significación que abarca el enunciado /ciencia superior a magia/.

II

El segundo esquema corresponde a la heterogeneidad total que Lucien LévyBruhl (1978) encuentra entre lo que él denomina el pensamiento prelógico y el pensamiento occidental. En virtud de hallarse regidos por reglas diferentes, este autor excluye la posibilidad de relacionar los dos tipos de pensamiento. Así, el pensamiento occidental se enfrenta a la imposibilidad de comprender la mentalidad primitiva, por estar esta última regida por la 'ley de participación' - que se refiere a la propiedad del pensamiento de penetrar en la naturaleza a través de una 'experiencia mística'- la cual no tiene correlato en la 'explicación' de tipo científico.

Frente al esquema de sucesión, que privilegia la dimensión temporal y diacrónica, el esquema de Lévy-Bruhl anula la brecha temporal pero profundiza la diferencia de contenido. Para el evolucionismo la distancia entre magia, religión y ciencia es mera cuestión de tiempo: las sociedades tradicionales tendrán que superar algún día sus estadios fetichistas, politeístas o de falsa conciencia y lo lograrán gracias a la uniformidad de fondo del género humano: la unidad de su espíritu. El esquema que se apoya en la noción de heterogeneidad levanta un muro infranqueable entre el occidental y el otro, y aún si ambas mentalidades coexisten, lo mismo da, puesto que no podrán establecer comunicación. La unidad morganiana del espíritu humano, a que apelará más tarde el estructuralismo, queda sin efecto en el esquema heterogéneo, para afirmar que existe, por lo menos una regla que no es común a todos los hombres y que los hace esencialmente diferentes. 
Como "padre fundador del romanticismo" en los términos de Schweder, LévyBruhl se mostró renuente a aceptar la concepción de Tylor y Frazer en el sentido de que "el primitivo" era un científico en ciernes, aunque confundido:

"Lévy-Bruhl aseguraba que los cánones que gobiernan el pensamiento de los así llamados primitivos no son deductivos, ni inductivos, ni causales. El primitivo, decía, no es un mal científico; es un buen místico" (Schweder 1991:91).

Al adjetivar a una cultura completa como "prelógica", Lévy-Bruhl llega al extremo de afirmar que una cultura puede sobrevivir en completa ausencia de lógica. Sin embargo, este esquema tiene a su favor la preocupación por la especificidad del pensamiento no occidental frente al occidental y el interés por el estudio de sus mecanismos internos. Este último, si no logró con LévyBruhl llegar a sus últimas consecuencias, sentó las bases a partir de las cuales Marcel Mauss y otros autores avanzaron significativamente.

El postulado de que existen muchos puntos en una estructura de conocimiento más allá del alcance de los estándares universales de la lógica y la ciencia, es recuperado más tarde por la antropología cognitiva y la etnociencia. Cuestiones como verdad y falsedad, error y validez, no vienen al caso en este esquema, al cuestionarse sobre los criterios que gobiernan los sistemas clasificatorios.

$\mathrm{Al}$ adentrarse en el reino de la arbitrariedad, no hay regla de lógica ni ley de la naturaleza que dicte lo que es apropiado o necesario que creamos. En estos intersticios de los sistemas, de apariencia ilógica, es donde la antropología cognitiva ha mejorado nuestra comprensión del tipo de ideas que subyace a la acción no racional, y ha llegado a ser cada vez más evidente que el lenguaje, el pensamiento y la sociedad se construyen sobre ideas que caen más allá del territorio de la evaluación lógica o científica, ideas para las que no hay criterios normativos universalmente vinculantes (Bateson 1990).

La idea de la diversidad cultural como cambio de marco es clásica dentro de la antropología cognitiva: aprender una lengua es aprender cuáles clasificaciones se imponen al mundo objeto. Lógicamente, cualquier clasificación es posible, ninguna es mejor o peor, excepto para algún propósito humano en especial. Las definiciones tipológicas a priori son para esta escuela absolutamente 
inservibles en la práctica, la obligación del antropólogo es realizar una descripción en términos que sean congruenteś, tanto con el fenómeno analizado como con las conceptualizaciones nativas. La etnografia se convierte así, no en una técnica, sino en un fin científico en sí mismo (Reynoso 1986:23).

En este sentido, si los criterios componenciales reflejan directamente la realidad psicológica, bastará reunir un número suficiente de descripciones, aprehenderlas y seguir su curso para poder comportarse como, o pasar por, un nativo. Sin embargo esta postura debe reconocer que el universo nativo alberga muchas más cosas que las que pueden encontrarse en las relaciones taxonómicas, y que la simetría en la articulación conceptual de un dominio no guarda proporción alguna con su relevancia cultural. Al final, tanto la etnociencia como la antropología cognitiva —en sus distintas versiones- han tenido que diluir las fronteras de sus propias dicotomías para reconocerse ya no como emic, ni etnográficas, ni cualitativas; por el contrario, tuvieron que devenir etic, etnológicas y cuantificadoras, y hasta han tenido que aventurarse en nuevos espacios epistemológicos ${ }^{1}$.

$\mathrm{Si}$ en los estudios sobre modelos folk de clasificación se percibe que los esquemas clasificatorios reales de los distintos pueblos tienden a confundirse con los que el analista fabrica, sobre la base de distinciones que él mismo suscita, el reto del investigador consiste no sólo en alcanzar una profundización adicional que garantice que una taxonomía folk no sea un constructo del etnógrafo: hay que garantizar que las distinciones identificadas sean pertinentes en la vida cotidiana y social, o bien disponer de un método capaz de confirmar que las distinciones pertenecen de antemano al universo estilístico y categorial de discriminaciones propio del pensamiento nativo ${ }^{2}$.

${ }^{1}$ Pyke define el concepto emic como el conjunto de los sistemas lógico-empíricos cuyas distinciones están basadas en contrastes y discriminaciones que los actores consideran significativos; como etic el corpus de predicciones que dependen de las distinciones consideradas significativas por la comunidad de observadores científicos (Pyke 1993:5).

${ }^{2 "} \mathrm{El}$ análisis componencial sostiene argumentos que son esencialmente descriptivos y que no sirven para reducir la complejidad de los sistemas a analizarse. El análisis transformacional, por el contrario, apunta al corazón de los sistemas, produciendo reglas simples capaces de generar todo el material que encuentra el analista de componentes, además del que podría llegar a encontrar. El análisis componencial es análogo a la 
El tercer esquema surge de una reflexión como la siguiente: si los trobriandeses no están a la distancia de dos o tres "períodos étnicos" sino "aquí y ahora", y su modo de pensar no es sustancialmente distinto, sino inteligible para el observador, entonces el problema no radica en la sucesión ni en la heterogeneidad entre dos cuerpos de pensamiento: el problema está en otro lugar. Para el funcionalismo de Bronislaw Malinowski no se trata de clasificar el conocimiento de los trobriandeses en un modelo de diacronía, sino en esclarecer sincrónicamente cómo frente a un problema técnico de naturaleza análoga a los que se presentan en sociedades dominadas por la ciencia, su respuesta 'se desvía' hacia la magia. Tanto la ciencia como la magia, dice Malinowski, están orientadas a la satisfacción en última instancia de necesidades de orden material, pero si, la pesca en alta mar - por ejemplose enfrenta a imponderables que el nivel técnico alcanzado por los trobriandeses no permite controlar, la inseguridad resultante es compensada mediante el recurso de la magia. Así, ante el escaso manejo de la ciencia por parte de los isleños, la magia intenta prefigurarla pero sin alcanzarla jamás: por más que los principios técnicos en que ambas se sustentan sean similares, llegará el punto en que los trobriandeses "yerren" y vuelvan irremediablemente la mirada hacia el corpus de conjuros mágicos de la comunidad. Estamos frente a una explicación en términos de anxiety reduction or compensatory action (Malinowski 1977).

Malinowski dibuja una clara separación entre ciencia y magia; la primera, profana, mientras la segunda, junto con la religión, pertenece al terreno de lo sagrado. Esta demarcación se opone básicamente al esquema de Tylor y Frazer, quienes agrupan a la magia como "pseudociencia", pero su caracterización de ciencia es tanto simplista como generosa: generosa, al

descripción morfológica de un organismo; el transformacional equivale a su descripción ontogenética. Aquél describe estados finales, de extraordinaria complejidad; éste demuestra que los estados complejos no son más que el resultado de la aplicación repetitiva o recursiva de ciertas reglas sobre estructuras nucleares o fundamentales. Un análisis componencial está en la misma escala que el fenómeno que toma por objeto, por lo que resulta en un modelo mecánico; un análisis transformacional está en una escala distinta que la del fenómeno, por lo que conforma un modelo estadístico (Reynoso 1986:61)" 
designar a los trobriandeses como poseedores de conocimiento científico y simplista, si la ciencia es definida en los términos de los filósofos e historiadores de la ciencia contemporáneos como un proceso reflexivo, autoconsciente y siempre abierto de construcción de conocimiento.

Si bien Malinowski no avanza mucho con esta demarcación entre ciencia y magia, lo que resulta interesante es su atención, en los límites de una sociedad particular o cultura, sobre las actividades simbólicas - rito y magia - ligadas e interactuantes con aquéllas de carácter pragmático. Es decir, este autor se cuestiona sobre los siguientes aspectos: 1) cómo entender la participación humana en, al menos, dos modos de realidad; 2) la capacidad del hombre de pasar de un contexto al otro y 3 ) cómo ambos contextos entran en una relación de complementariedad.

Por su parte, Malinowski define la religión por su función, primariamente psicológica y después sociológica, y por su distinción en términos de medios instrumentales y fines trascendentes. La acción religiosa no es como la mágica: un medio para alcanzar un fin, la religión es un fin en sí mismo y se consagra a valores últimos, tales como la providencia y la inmortalidad. Los actos religiosos son, en este contexto, actos de fe: en los ritos religiosos, medios y fines son una sola cosa. Los ritos de iniciación y matrimonio no pretenden provocar el fin en cuestión, son en sí mismos la transformación. En este sentido Malinoswki anticipa la noción austiniana de acto performativo, saying is doing, siempre y cuando personas acreditadas, bajo condiciones convenientes, realicen los actos adecuados (Tambiah 1990:69).

De ahi la importancia que presta Malinowski al estudio de los conjuros y la dimensión fática del lenguaje, cuyo resultado a largo plazo es el análisis de los mensajes mágicos y su efecto en el lenguaje (Jakobson 1980). En otro contexto, Barthes (1968 y 1971) se refiere al efecto mítico del lenguaje y pensamiento modernos y admite que es virtualmente imposible evadirlos: el grado cero en la escritura produce sus propios efectos mágicos ${ }^{3}$, al tiempo que Ellul (1968) refiere un proceso similar en la propaganda. El antecedente de estas interpretaciones se encuentra en las afirmaciones de Marcel Mauss en el sentido de que las asociaciones entre palabras presentes en los sistemas primitivos de clasificación - relaciones simpáticas-subyacen al lenguaje

${ }^{3}$ Si bien otros autores, como Paul Ricoeur, cuestionan el grado cero. 
(Durkhéim y Mauss 1963). Cazeneuve (1970) demuestra por su parte, que los efectos de la magia simpática son intrínsecos a toda lengua, y que tales procesos asociativos crecen de manera tangencial en la historia de la civilización, pero únicamente determinadas prácticas del mundo moderno vuelven a colocarlos en el escenario: la propaganda, la publicidad y los movimientos milenaristas, entre otros, recargan sus baterías con asociaciones lingüisticas simpáticas. La publicidad y la propaganda no sólo reaniman lazos simpáticos, sino que construyen nuevas asociaciones mágicas al interior del lenguaje, las cuales, al ser confirmadas y perpetuadas por los medios de comunicación masiva son naturalizadas hasta el punto de hacernos creer que sus contradicciones son naturales (O'Keefe 1982:477). En este nuevo mundo, un evento real no existe hasta que está certificado por un pseudoevento (por ejemplo, la conversión de una tragedia humana en la historia del día por la prensa electrónica).

Si bien Malinowski no es un teórico de la religión, en sus análisis de la magia trobriand efectúa un importante avance, al separar los hilos de actividad práctica y mágica que forman la trama o doble hélice de la vida isleña. En Coral Gardens and Their Magic asevera que las secuencias rituales y técnicas son paralelas, y sus etnografias más coloridas muestran cómo los ritos mágicos penetran casi todos los aspectos de la vida trobriand.

Es un hecho que existen ritos que tienen un carácter definido y que se ejecutan a manera de representaciones especiales ajenas a los eventos de la vida cotidiana. Estas representaciones son analizables en términos del esquema tripartita de van Gennep (1909) — separación, liminalidad, agregaciónesquema que Turner (1974) explotó brillantemente. Pero, simultáneamente, se llevan a cabo toda clase de ritos, cíclicos o intermitentes, que se entrelazan efectivamente con actividades meramente prácticas tales como la agricultura, la pesca y otras. Ambos tipos de actividad, la técnica y la mágico - religiosa, constituyen amalgamas que, aunque a menudo se distinguen internamente, ocupan el mismo tiempo y el mismo espacio, lo que hace imposible una desagregación de sus aspectos en técnicos y expresivos ${ }^{4}$.

${ }^{4}$ Esto explica el avance en los estudios que proporcionan la base documental que sitúa a la magia como el origen de muchas artes y oficios. Cerámica, metalurgia, fabricación de armas, fueron desarrolladas durante siglos por hermandades de magos que mantenían las fórmulas en secreto (Tambiah 1990) 
En esta perspectiva, al contrario del evolucionismo que sugiere "esperar" a que las sociedades tradicionales abandonen la magia y la religión, aquí el avance de la ciencia satisfará la necesidad de control técnico que la magia es incapaz de proveer. El esquema de la insuficiencia se traslada entonces, en ámbitos no étnicos o contemporáneos, a algunas interpretaciones que definen el pensamiento mágico como insuficiente y equivocado - ciencia abortiva 0 errada - o bien equivalente de la 'ignorancia' ${ }^{5}$.

\section{IV}

Evans-Pritchard retorna a la discusión en el punto en que Lévy-Bruhl la abandona, para afirmar que no se trata de cuestionar el llamado pensamiento primitivo en su calidad de poseedor o carente de lógica, ya que en su estudio de la magia azande da por hecho que cuenta con una. Así, transporta su pregunta al problema de la racionalidad. En oposición al etnólogo francés, Evans-Pritchard (1976) reprueba la idea de que la comprensión científica de causas y efectos, que lleva al occidental a rechazar ideas mágicas, sea evidencia de una inteligencia o de un tipo de pensamiento superior. Señala, por su parte, que este acercamiento científico es una función, antes que nada, de la propia cultura. De esta manera, el autor británico abre una serie de cuestionamientos, al ir más lejos en esta dirección que la mayoría de sus predecesores, al tratar de dar cuenta del sentido de las instituciones de las que se ocupa, tal y como se les presentan a los mismos sujetos, en este caso, los azande.

Elegir la noción de la racionalidad para asomarse a una cultura, equivale a preguntarse cómo un sistema de "creencias erróneas y de prácticas ineficaces" puede mantenerse a sí mismo frente a objeciones al parecer obvias. Sin embargo, al caracterizar lo científico en términos del discurso que concuerda con una realidad objetiva; el autor británico concluye que únicamente la

5 "In everyone of us there is a scientist who is asleep, and who will not wake up until social and cultural conditions are pushed aside." (Latour 1987:185) 
concepción científica tiene esa facultad.

La discusión contemporánea sobre la racionalidad, inspirada en parte por las dudas de Evans-Pritchard, es sintetizada en la crítica de Winch (1991) en el sentido de que tanto la distinción entre lo real (objetivo) y lo irreal, como el concepto de concordancia con la realidad, sólo pertenecen a nuestro lenguaje. Por tanto, la pregunta pertinente es cómo, con referencia a qué universo de discurso establecido, debe explicarse el uso de determinadas expresiones. Esta argumentación parte del rechazo de Wittgenstein (1988) a la idea de que debe haber una forma general de proposiciones. Este filósofo llama la atención sobre el número indefinido de usos diferentes que puede tener el lenguaje y trató de mostrar como el 'acuerdo o desacuerdo con la realidad' toma tantas formas diferentes como usos diferentes del lenguaje hay ${ }^{6}$.

La noción de 'juego de lenguaje' se impone entonces como una posibilidad de diluir la dicotomía entre los dos cuerpos de conocimiento: las nociones presentes en las clasificaciones tradicionales sólo pueden ser interpretadas en el contexto de las formas de vida de esos pueblos. Esta idea, que concluye en una propuesta de definición de las 'formas alternativas de discurso' -propia de algunos trabajos que pueden agruparse alrededor de la 'antropología posmoderna' - desemboca en la exigencia de reformular la investigación sobre el terreno: si nosotros, como occidentales, no tenemos ni remotamente una clasificación que se parezca a la categoría zande de magia, por ejemplo, tenemos la obligación de ampliar nuestro modo de comprender, de tal manera que le abramos un espacio a la categoría zande de magia, en lugar de insistir en verla en términos de nuestra propia distinción preestablecida entre ciencia y no-ciencia.

${ }^{6}$ Este razonamiento puede resumirse de la siguiente manera: en virtud de que la experiencia no es fuente de conocimiento, ésta debe ser formulada idealmente a priori, por lo que sólo el trasfondo (contexto cultural) determina lo real y lo no real. Todo lo representado es un mito y la verdad de las representaciones empíricas se deriva de un sistema de referencia compuesto por un conjunto de proposiciones ligadas entre si por relaciones necesarias. Así, al desaparecer las categorías a priori, desaparece el método tradicional de la antropología (que busca definir parentesco, economía, etcétera) y se perfila la búsqueda de un campo intersticial entre la exégesis y la explicación. 
Este esfuerzo es válido en tanto que propone adentrarse en las categorías de los lenguajes y sistemas clasificatorios nativos, pero al dotarlos de una 'racionalidad' esencialmente distinta de la nuestra, se enfrenta al problema de su inteligibilidad.

La discusión se dirige entonces hacia la imposibilidad de 'entender', con las categorías propias de nuestro lenguaje, esos discursos alternativos, se trata de la adquisición de nuevas competencias ideológicas y lingüísticas entendidas como sistemas de ideas. Lo que conlleva hacia otro problema: la definición de trabajo del antropólogo debe optar por 'comprender', 'interpretar' o 'traducir' el conocimiento nativo. Este punto es, a nuestro parecer, en el cual el esquema basado en la noción de racionalidad se topa con dificultades: si es consecuente con él mismo, no deberá privilegiar el uso de herramienta alguna para el análisis, puesto que la naturaleza de los enunciados no debe presuponerse. Las recomendaciones en el sentido de realizar una 'descripción densa' de los fenómenos estudiados (Geertz 1987), o de 'aprender la cultura como un niño lo hace con la lengua materna' (MacIntyre 1988) no pretenden ser orientaciones de método, puesto que la existencia misma de un método traicionaría la base filosófica sobre la que se sustentan.

De cualquier manera, este esquema sigue proclamando la heterogeneidad aunque trasladada al nivel de los usos del lenguaje - entre los dos cuerpos de conocimiento, por lo que podemos afirmar que en lugar de disolver la dicotomía, la transporta hacia otro terreno. De manera análoga, al intentar resolver este punto, Jack Goody (1985) hace una crítica de los modelos bipolares occidental / no occidental, sustituyéndolos por otro en que los polos se estructuran alrededor de lo 'oral' y lo 'escrito'.

En este punto, la pregunta sigue siendo cómo trazar la línea que secciona la actividad cognitiva humana en dos cuerpos de conocimiento diferencialmente definidos. Cabe señalar que la respuesta debería considerar el elemento que queda implícitamente fuera de cuestionamiento: el proceso de conocimiento científico.

En el esfuerzo por construir modelos bipartitas o tripartitas, el elemento común -el pensamiento científico- es el que presenta un menor número de problemas para su definición. Visto como cuerpo de proposiciones con una existencia relativamente reciente, y desarrollado en un tiempo y espacio más o 
menos delimitado, la ciencia no puede ser más que única. Frente a ésta, el resto del conocimiento humano, que en términos de extensión es infinitamente superior al primero, se presenta como diverso, complejo, arbitrario, amorfo.

Con base en la investigación sobre el desarrollo de la actividad tecno científica, Latour (1987) desarrolla una serie de conceptos que le permiten desmontar la noción de racionalidad y dar cuenta del problema desde la perspectiva alterna. Aborda la polémica fundada por Evans-Pritchard en torno a la racionalidad o irracionalidad de las lógicas azande e inglesa en Science in action, a partir de ejemplos tan familiares para el occidental como los oráculos para los azande?

Las certitudes de los millones de personas del mundo occidental que opinan sobre el clima, evocadas por Evans-Pritchard (1976) se convierten en meras opiniones, puesto que la esencia del clima es definida por unos cuantos meteorólogos. Obedeciendo las mismas reglas que Evans-Pritchard, un hipotético antropólogo zande enjuiciaría a los no meteorólogos ingleses por sostener creencias irracionales.

En este momento, se traza la línea que divide por un lado las creencias sobre el clima, y por el otro el conocimiento sobre el mismo. Esta caracterización corresponde a la que se hacen los científicos insertos en una poderosa red sobre lo que ocurre al exterior. En opinión de Latour, las creencias se definen

${ }^{7}$ Todos los días millones de personas hablan sobre el clima, hacen predicciones, citan proverbios, observan el cielo. Entre ellos, una gran proporción escucha los reportes o mira las imágenes de satélite, la gente bromea sobre las equivocaciones de los meteorólogos y algunos rigen actividades como plantar, volar aviones o ir de picnic por el contenido de los reportes. En las estaciones, pocos miles de meteorólogos trabajan intentando definir lo que el clima es, ha sido y será, apoyados por el manejo de enormes bases de datos alimentados vía satélite, informes de otros centros meteorológicos del planeta así como modelos computarizados. A la pregunta ¿cómo estará mañana? responden por un lado, millones de comentarios dispersos y por el otro, juicios de la Asociación Meteorológica Internacional. ¿Ambos grupos de comentarios poseen una base en común? No, en efecto, porque millones de bromas, proverbios, evaluaciones, e intuiciones se pierden entre los juicios de meteorólogos, quienes son los únicos capaces de definir lo que el clima es y sólo sus opiniones cuentan realmente cuando se trata de obtener fondos necesarios para hacer uso de computadoras, instrumentos, satélites, sondas, que proporcionan los datos necesarios. 
por su subjetividad: dicen más sobre quien las sostiene que sobre el tema en sí; el conocimiento, por el contrario, es objetivo, o al menos tiende a serlo y se refiere al objeto y no al tipo de personas que son los meteorólogos. Aún en los casos en que las creencias llegan a coincidir con el saber, se trata, desde esta perspectiva, de un mero accidente que no les resta subjetividad. Para aquéllos al interior de las redes de conocimiento, la única manera de saber acerca de los climas y su evolución consiste en aprender lo que los científicos han descubierto. Se instituye entonces una di-visión entre aquéllos que tienen acceso a la naturaleza de los fenómenos y aquéllos que, por no haber aprendido lo suficiente, sólo tienen acceso a imágenes distorsionadas de los mismos (Bourdieu 1984).

La línea recta que indica el camino de la ciencia — por la que se debe caminar - es definida como lo racional; la desviación que desafortunada y efectivamente mucha gente sigue es lo irracional. Estos dos adjetivos, presentes en el discurso, sólo tienen sentido emitidos desde el marco que proporcionan las redes científicas; es decir, sólo tienen sentido si se acepta de antemano la distinción entre creencia y saber.

La larga distancia entre hechos duros y suaves se extrapola a las culturas que 'creen' en cosas y por el otro, una cultura - la nuestra - que 'sabe' cosas o las sabrá. Supone la falacia de un conocimiento o saber inmerso en la sociedad y de otro, el científico, independiente de ella. Estas argumentaciones no se ocupan por el contenido del conocimiento, sino por las condiciones que llevan a, o ayudan a conseguir, dicho contenido, lo que da pie a una explicación asimétrica.

Una manera de evitar la asimetría sería considerar a la creencia o conducta irracional como resultado de una acusación. Para ilustrar dicha estrategia, Latour explica como para los azande la aplicación simultánea de dos reglas opuestas no produce contradicción alguna: 1) la acusación de brujería se extiende al clan, 2) si un miembro del clan es acusado de ser brujo, esto no significa que el resto de sus miembros lo sea. En lugar de verlo como una contradicción y combatirla, a los azande simplemente parece tenerlos sin cuidado. Tal indistinción garantiza la acusación de irracionalidad, pero el mismo Evans-Pritchard saldría en su defensa puesto que, según él, los azande prefieren comportarse irracionalmente para proteger la estabilidad de su sociedad. 
¿Cómo se puede ignorar una distinción entre creencias y actos racionales e irracionales que es tan definida y tan borrosa al mismo tiempo? ${ }^{8}$ Lo que ocurre es que los azande nunca incluyen la posibilidad de contaminar el clan entero en la definición de transmisión de la brujería. Por lo que el "error" no está del lado de los azande por no entender la lógica, sino en Evans-Pritchard por no considerar el campo semántico de la definición zande de brujería.

Por la otra cara de la moneda, frente al cargo de irracionalidad, el relativismo arguye que todo depende del punto de vista y ofrece una nueva perspectiva en la que todo juicio parece correcto. Se trata de una explicación simétrica que toma en cuenta los factores sociales para 'explicar' el desvío del camino recto. Aparece como más equilibrada, pero persiste, igual a su contraria, en evadir la definición de la actividad tecno - científica.

El punto de interés lo constituye el cruce de caminos, la intersección de dos taxonomía en conflicto, a una se califica como etnotaxonomía sólo porque es particular a un grupo; mientras que la otra es llamada simplemente taxonomía, porque es particular a los estudiosos naturalistas. ${ }^{9}$. Lo que parece estar en disputa son determinadas 'estructuras del lenguaje', 'taxonomías', 'culturas', 'paradigmas' o 'clasificaciones' que sintetizan el conjunto de elementos que sirven para definir al otro, y cuyas fronteras se restablecen cada vez que un conjunto de elementos tiene que ser modificado, al transformarse una

${ }^{8}$ La hipótesis del antropólogo zande revierte la acusación de irracionalidad hacia la cultura occidental. Al suponer que el juicio "matar gente es asesinato" incluye implícitamente la situación de guerra, el antropólogo argumenta triunfantemente que se trata de una muestra de irracionalidad. Pero resulta que la noción de asesinato nunca ha implicado la situación de guerra (excepto en casos extremos) y no es culpa de la gente si el antropólogo no entiende el significado de la palabra "asesinato" y si no está familiarizado con su defínición occidental. Lo que está equivocado no es nuestra "creencia desviada" sino, por el contrario, la relación trazada por el antropólogo zande.

- La geografía implícita del nativo es hecha explícita por los geógrafos, el conocimiento local se convierte en el conocimiento universal de los cartógrafos, las creencias borrosas, aproximativas y $\sin$ bases de los locales se vuelven conocimiento preciso, cierto y justificado. Pasar de la etnogeografía a la geografía es como pasar del salvajismo a la civilización. 
asociación o porque se funda una nueva.

Con el propósito de fortalecer su taxonomía la gente trata de hacer que sus juicios aparezcan más creibles que los de los otros, y al hacerlo delinean cadenas de asociaciones - de naturaleza impredecible y heterogénea- que construyen su propia socio-lógica ${ }^{10}$.

En otras palabras, el conocimiento no puede explicarse en sí mismo o por oposición a 'ignorancia' o 'creencia', puede ser considerado, como lo hace Latour, como un ciclo completo de acumulación que le permite convertirse, en determinado momento, en el punto central de un proceso que actúa sobre muchos otros puntos situados a distintas distancias de él.

La línea entre creencia y saber, magia y ciencia, prelógico y lógico, salvaje y civilizada, está presente en estos esquemas debido a su interés en la delimitación, en el establecimiento de la diferencia, de mutua exclusión ya sea en términos de sucesión y ruptura entre magia, religión y ciencia en la tradición positivista; de heterogeneidad total entre formas lógicas y prelógicas en Lévy-Bruhl; de la insuficiencia del pensamiento mágico frente al científico en Malinowski; o la ausencia de objetividad del conocimiento azande que encuentra Evans-Pritchard.

No obstante, en la aceptación de su diferencia, nuestras preguntas privilegian la interdependencia, la complementariedad y por qué no, la necesidad de coexistencia de varios tipos de conocimiento que apelan ya sea a una o a varias lógicas simultáneas, al empleo de operadores lógicos abstractos o concretos, o a sus condiciones de producción.

${ }^{10}$ Ejemplo de un sistema clasificatorio intersectado es el funcionamiento de la astrología. Como visión del mundo basada en una clasificación totémica: 1) propone analogías que son iconos, mitogramas, mitemas; 2) establece un campo amplio de interpretación; 3) la referencia continua a un esquema de clasificación trae consigo su uso, por ende su norma, y su aceptación; 4) fortalece el esquema clasificatorio y se refuncionaliza de acuerdo al contexto. 


\section{LOS TRES VÉRTICES DEL TRIÁNGULO}

La constante en la demarcación de dos grandes cuerpos, o en última instancia, la gran línea creer/saber, parece a simple vista reproducirse en el modelo de Lévi-Strauss, quien define por un lado a la ciencia y por el otro un conjunto de lógicas de lo concreto. O bien, un esquema tripartito en el que un tercer elemento - el arte-media entre los pares opuestos.

El alcance de la propuesta de El pensamiento salvaje no obstante, va más allá, al situarse como un esquema construido, no a partir de los elementos, sino en torno a la relación entre dos conjuntos de conocimiento: el nombrado como 'científico, occidental, positivo, domesticado' y por otro lado, el denominado 'mentalidad primitiva, prelógico, falsa conciencia, mágico - religioso, mito, bricolage'.

Al afirmar que el segundo tipo de conocimiento está igualmente reglamentado, el carácter inconsciente de sus reglas y su registro heteróclito, Lévi-Strauss establece una ruptura epistemológica frente al resto de los esquemas, al colocar en posición de analogía formal ambos tipos de conocimiento:

"...existen dos modos distintos de pensamiento científico, que tanto el uno como el otro son función, no de etapas desiguales de desarrollo del espíritu humano, sino de los dos niveles estratégicos en que la naturaleza se deja atacar por el conocimiento científico: uno de ellos aproximativamente ajustado al de la percepción y la imaginación y el otro desplazado..." (Lévi-Strauss 1984:33, cursivas mías)

En cierto sentido, el pensamiento salvaje alcanza una magnitud sin proporciones si se compara con el relativamente reducido ámbito del pensamiento científico. No obstante, en el esquema levistrosiano el primero queda reducido al segundo, al ser considerado como un tipo de conocimiento científico. Desde luego, el reconocimiento de la existencia de dos tipos de conocimiento científico tiene como uno de sus propósitos disolver las creencias en torno a la calidad inferior de uno de ellos. Al mismo tiempo que desmonta paso a paso dicha creencia, da lugar a su proposición de la existencia de una lógica de lo concreto, con leyes y operadores particulares, 
que no son los de la ciencia, pero sí análogos a ella.

No se trata de oponer el pensamiento 'en su estado salvaje' al 'pensamiento domesticado', pero propone una nueva relación de exclusión entre 'dos tipos de conocimiento científico', en la que uno está bien delimitado - la cienciamientras que el otro se define vagamente y por oposición al primero. Sin embargo, las propuestas orientadas hacia definir los mecanismos específicos mediante los cuales opera la 'lógica de lo concreto' apuntan efectivamente hacia un paisaje de varias tonalidades.

El modelo de Lévi-Strauss establece, a diferencia de otros esquemas, no uno, sino un conjunto de elementos de conjunción y disyunción entre ciencia y ciencia de lo concreto. A su analogía formal, producto de la misma clase de operaciones mentales que exigen, se opone los resultados teóricos y prácticos que obtienen. Las clases de fenómenos a los que se aplican tienen más que ver que la actitud mental, la curiosidad y el gusto por el conocimiento presente en ambos. El determinismo global e integral de la ciencia de lo concreto contrasta con los niveles diferenciales que la ciencia reconoce: es más una interrelación específica del signo y el concepto, el acontecimiento y la estructura, el rito y el juego, la humanidad y la realidad, que un deslinde y una exclusión.

Si efectivamente lo que se había considerado como un conjunto homogéneo de 'pensamiento en estado salvaje' es a su vez, un conjunto heteróclito de lógicas - preferentemente de carácter concreto- en constante relación con otro conjunto de operadores preferentemente de carácter abstracto; entonces el trabajo interpretativo consistirá no sólo en aislar los fenómenos en dos grandes campos de conocimiento (ciencia/ no - ciencia o ciencia/ciencia de lo concreto) sino en identificar lo que en cada uno de ellos existe de 'concreto' o de 'abstracto' y de esta manera deslindar y clarificar el polo que se presenta como más nebuloso: el de las lógicas de lo concreto. En este sentido, este modelo supera efectivamente la dicotomía fundamental, al mismo tiempo que plantea nuevas preguntas.

Desde el punto de vista de su valor heurístico, la respuesta levistrosiana significa un auténtico replanteamiento de la problemática. A lo largo de tres décadas, su influencia ha sido determinante en la naturaleza de las preguntas que los sistemas conceptuales se plantean al respecto. Las diferentes lecturas que se hacen de su obra abarcan un amplio espectro del discurso antropológico 
moderno, a saber: cognitivismo, interaccionismo simbólico, estructuralfuncionalismo, desconstructivismo y antropología posmoderna, presentan alternativas que apuntan en direcciones divergentes pero que, sin embargo, evocan el núcleo de la cuestión ${ }^{11}$.

Otro de los vértices del triángulo, la relación entre ciencia de lo concreto $\mathrm{y}$ arte, no ha sido contemplada más que tangencialmente. No obstante, para dar cuenta de sistemas de representaciones, ya sea en el registro plástico o en el literario, la noción de arte se instituye como mediadora entre los dos tipos de conocimiento científico, manteniendo relaciones tanto metonímicas como metafóricas con ambos.

En mi opinión, el carácter de modelo gráfico de este sistema triangular de relaciones, establece la necesidad de descubrir el contenido particular que cada cultura le confiere en un campo de conocimiento determinado. Los límites establecidos por Lévi-Strauss, y que corresponden a ciertos contenidos propios de la cultura occidental, pueden ser redefinidos en cuanto a sus contenidos específicos en una formación cultural étnica o interétnica. La posición de la noción de arte (si existe como tal) en una formación cultural particular debe contemplar las fronteras del triángulo a partir del análisis del contenido particular que en cada situación étnica adquiere este concepto ${ }^{12}$.

11 A 34 años de la aparición de El pensamiento salvaje, la referencia a esta obra cuyos alcances etnológicos, estéticos y filosóficos exigen el reconocimiento de que la trascendencia del pensamiento levistrosiano superó todas las expectativas generadas en su tiempo. En 1981 una encuesta realizada por la revista Lire mostró que Lévi-Strauss era entonces el pensador más influyente en los medios intelectuales franceses. Seis años más tarde, Iván Zavala afirmó que "es muy probable que si esa encuesta se repitiera hoy, el resultado sería el mismo" (Jáuregui y Gourio eds. 1986:261). En la actualidad su influencia se deja sentir desde el campo del psicoanálisis y la crítica literaria hasta el de la música pop (vgr. El grupo de rock inglés "Fine young cannibals" tituló a su segundo álbum The Raw And The Cooked 1988, FFRR, Records Ltd., La composición operística basada en las Mitológicas y el filme suizo El Trasatlántico). En 1998, como festejo de su nonagésimo aniversario, Lévi-Strauss (1998) respondió a Delacampagne y Traimond (1997) la revisión que estos autores hicieran de su histórica polémica frente a Sartre, la respuesta del maestro no sólo refleja su propia vitalidad sino también la vigencia de su argumentación.

${ }^{12}$ Por ejemplo, en náhuatl, no existe un término equivalente a nuestro concepto de arte. La expresión "flor y canto" in xochitl in cuicatl no incluye las mismas categorías que el concepto de arte posee en el contexto de un sistema cultural distinto. Una expresión, 
De esta manera, las lógicas que aparecen bien delimitadas en el modelo propuesto por el autor, (ciencia, ciencia de lo concreto y arte) de hecho se encuentran entrelazadas en el terreno de la cosmología, de la concepción del tiempo y del espacio y del conocimiento de las poblaciones Étnicas que conviven de una u otra manera con la sociedad mayor que se confiesa heredera de una tradición positiva.

Tomando como base la discusión que antecede, el punto de vista que me interesa desarrollar en esta tesis, parte del prespuesto de que es en los vértices del triángulo donde se sitúa la relación específica entre las lógicas entrelazadas, en una combinación sui generis para cada cultura, lo que conforma una clasificación o taxonomía cosmológicas.

La lectura de dicha clasificación reconoce que todo registro - arquitectural, vestimentario, musical o de cualquier otro tipo- evoca una cosmología por estar presente lo que es el fondo del mito: la ordenación lineal y la repetición, la narratividad articulada en torno a formas y ritmos. La clasificación constituye la cultura y lo que instaura las diferencias entre las etnias. La particularidad del comportamiento estético, inaccesible a la clasificación verbal - más cercano a la noción de mitograma- es un estilo que posee su valor propio y que baña la totalidad cultural del grupo. Dicho estilo está comprendido en la noción de cultura entendida como la memoria no hereditaria, el conjunto de información que recoge, conserva y transmite la sociedad humana, expresada en un determinado sistema de obligaciones y prescripciones (Lotman y la Escuela de Tartu 1979:21) (3) $^{13}$

común en nuestro medio, como la de 'arte prehispánico' no tiene sentido más que violentando la categoría de arte al incluir en ella, por ejemplo, a la escultura monumental mexica. Con base en las características de su contexto significativo, las esculturas monumentales se sitúan en el campo semántico de las obras de infraestructura llevadas a cabo por el aparato estatal, a mismo título que las represas y los caminos desbrozados. En un mismo movimiento, este tipo de acercamiento arroja luz sobre nuestras categorías: la expresión 'arte prehispánico' no es un concepto, puesto que no hay unicidad; cuando la usamos, hacemos una metáfora. 1979: 22)

13 "La historia de las sociedades es la historia de la lucha por la memoria" (Lotman 
La ordenación y repetición en torno a formas y ritmos sostiene la necesidad de someter los términos, surgidos en el desorden, a una disciplina gramatical: significar no es otra cosa que establecer una relación entre términos, esto es, fundar una asociación.

Así, el principal reto que se presenta al intentar reconstruir una cosmología, como sistema de asociaciones heterogéneas, consiste en no hacer ninguna asunción adicional sobre cuál criterio lo rige. Lo que realmente interesa sobre estas taxonomía es hacia dónde se dirigen, pero no, si son o no correctas, si son o no racionales.

Lo pertinente, entonces, de una taxonomía es la significación y no la corrección, por lo que conviene preguntarse de qué manera una formación cultural específica establece sus fronteras. La gran línea entre ciencia y mito parece desdibujarse al observar de cerca la intersección entre las lógicas abstractas y las concretas (incestos lógicos).

Los vértices posibles entre ciencia, mito y arte vuelven entonces a dibujarse siguiendo un contorno distinto en la situación de diálogo entre culturas interétnicas contemporáneas, auténtico laboratorio de intersecciones $\mathrm{y}$ transposiciones de campos semánticos. En este sentido, considero al campo de la cosmología como un dominio privilegiado en situaciones de convivencia entre dos o más sistemas clasificatorios lingüísticos y culturales, que se invaden constituyendo una intersección significativa desde la visión del mundo y estructuración de las unidades culturales pertinentes ${ }^{14}$.

Elegir esta perspectiva, equivale a reconocer que los sistemas culturales se encuentran en un proceso permanente de formación de metalenguajes, al asociar nuevos significados a significantes ya conocidos o a la inversa. Sin embargo no se asocia todo con todo: en el terreno de la cultura las opciones son discretas, por estar presente el presupuesto de un conjunto de reglas, es

${ }^{14}$ En náhuatl sólo los nombres de seres animados (personas y animales) pueden ser pluralizados, ya que los nombres de cosas y de plantas no admiten esta forma. Sin embargo, los lingüistas reconocen que debido probablemente a una personificación mitológica, los sustantivos tepetl "montaña", plural teteptl y citlalin "estrella", plural cicitlaltin sí aceptan una forma plural. 
decir, una gramática ${ }^{15}$.

Dicho código establece para cada cultura su opción de asociación y determina de qué manera una misma unidad cultural puede entrar a formar parte de campos semánticos diferentes que, a su vez, se deshacen y reestructuran en nuevos campos (Eco 1991:131). En virtud de esta propiedad de los lenguajes naturales, a diferencia de las entidades formalmente unívocas de los lenguajes artificiales, los signos pueden considerarse como unidades culturales cercanas a lo que la lógica llama hoy 'fuzzy concepts' o conjuntos borrosos (Lakoff 1975 y 1986).

Según esta perspectiva, todo en el universo está bien dentro, o bien fuera, de una categoría. Este concepto de categoría, que proviene de la teoría de conjuntos, supone que las cosas que están dentro de la categoría son aquéllas que poseen todas las propiedades inherentes requeridas, y cualquier cosa que carece de una o más de las propiedades inherentes cae fuera de ella. Sin embargo, para los seres humanos la categorización (clasificación) es un medio de comprender el mundo y debe servir a ese propósito de manera flexible, en virtud de lo cual los modificadores denominados hedges - barrera lingüística que limita la borrosidad de una categoría ${ }^{16}$ - identifican el prototipo de una categoría y definen diferentes tipos de relaciones con él.

De manera que si cada signo o elemento, en lugar de estar definido de una vez y para siempre dentro de un campo semántico, establece distintas relaciones con el prototipo, su definición no es en absoluto unívoca, sino que deriva en una suerte de árbol compuesto por el conjunto discreto de posibilidades semióticas que cada cultura le adjudica. Así, a las preguntas que planteo a un texto cultural sobre cómo se formó el mundo, o por qué se produce un eclipse, de inmediato se producirá una respuesta inscrita, ya sea dentro de la cosmovisión Étnica tradicional, occidental o sincrética, y si es sincrética con

15 "Si consideramos la filiación, resulta que no existen más que seis posibilidades lógicas de modos elementales, por combinación de cuatro unidades: hombre y mujer, en posición de padre y de hijo; y de las seis, al menos dos no aparecen casi nunca." (HéritierAugé 1974:40) Conviene mencionar aquí la pertinencia de la distinción entre los sistemas abiertos como el léxico y los sistemas cerrados, como la fonología y la sintaxis. punto/.

${ }^{16}$ Algunos ejemplos son /por excelencia/, /estrictamente hablando/, /hasta cierto 
respecto a qué cuerpo de conocimiento; o bien, se abrirá la posibilidad a respuestas científicas o populares.

Por lo anterior, conviene no sólo identificar la significación que implica la función semiótica: significante, lo que corresponde a la narratividad formal, significado

Sino también ubicar las posiciones connotativas y denotativas, así como el contexto y la circunstancia - tiempo y espacio culturales- en que tiene lugar la producción de signos.

La cultura así concebida aparece como un sistema de lenguajes cuyas manifestaciones concretas son textos de naturaleza plurilingüe. De acuerdo con la tipología de las culturas de Lotman -auténtica intersección de la semiótica y la antropología - por lo menos tres tipos de lenguajes entran en juego: naturales, artificiales y secundarios ${ }^{17}$. Sólo uno de ellos, el artificial, excluye la sinonimia o la capacidad de transmitir un mismo contenido en varios modos equivalentes, por lo que se acerca a la fórmula de entropía cero.

En virtud de que una cultura no es un sistema lingüístico único, Lotman plantea el problema de su transmisión y enseñanza como criterio definitorio de su tipología. Algunas culturas se consideran a sí mismas como una suma de precedentes, de modos de uso, de textos; otras, en cambio, como un conjunto de normas y reglas:

"Las primeras son el resultado de la enseñanza de un determinado comportamiento en que predomina el ejemplo. Fundan la cultura en cuanto suma de textos. Son culturas textualizadas que se orientan sobre la expresión. Las segundas fundan la cultura en cuanto metatextos. Se orientan sobre el contenido. Predomina la ley. Son culturas gramaticalizadas" (Lotman y la Escuela de Tartu 1979:27)

${ }^{17}$ Los lenguajes secundarios son llamados por el grupo de Tartu, sistemas de modelización secundarios. Término acuñado por B.A. Uspenskij, quien afirma que el lenguaje no sólo sirve para comunicar sino que modeliza, crea modelos. Los sms se sirven de la lengua natural como modelo, a partir de las lenguas naturales se conforman los sistemas culturales (Lozano en Lotman y la Escuela de Tartu 1979: 24) 
Ambos tipos coinciden con la distinción de Eco entre culturas hiper e hipocodificadas:

"La cultura gramaticalizada define las propias reglas de producción con metalenguaje explícito y reconocido por una comunidad discursiva entera -, mientras que en la cultura textualizada la gramática, si existe, sería investigada y reconstruida entre las logotécnicas que diversos sujetos colectivos tratan de imponer" (ibidem).

Las zonas del código que se entrecruzan constituyen la zona que se moldea, se somete al mestizaje o se reestructura. Se pueden dar casos en que los códigos culturales existentes se destruyan entre sí y casos en que la mezcla da lugar a un nuevo sistema más complejo: los procesos de pidginización y criollización que permiten la comprensión del plurilingüismo. Así se explican los cambios en el estado de la norma de una determinada lengua, así como el nacimiento de nuevas 'lenguas' producto de contactos culturales.

Esta visión de los textos culturales abre una variedad de caminos, al final de los cuales, sólo queda el que lleva de la lectura a la interpretación. La lectura, como primer paso, identifica los signos necesarios para la elaboración de un diccionario. Para ello es imperativo la identificación precisa de los elementos, su descomposición en componentes y la identificación de las reglas que proporcionan los sentidos, las rutas de interpretación. Una vez comprendidas éstas, su lectura provee las bases para la reconstrucción de una enciclopedia sobre la cultura.

Bajo esta nueva luz, transporto hacia otro terreno la división entre lógicas concretas y abstractas, puesto que mi interés radica en el punto donde confluye, en una cultura determinada, la multiplicidad de interpretaciones cosmológicas. Mi objeto de atención es justamente, la intersección de hipo e hipercódigos, los metalenguajes o campos intersticiales plurilingües.

Este acercamiento, que pretendo desarrollar en los capítulos sucesivos orientado a la cultura yaqui, es coherente con una categoría de mito en la que éste no se restringe al sentido de sobrevivencia en un mundo dominado por explicaciones científicas. Por el contrario, en la cultura contemporánea, la ciencia ha llegado a desbordar de tal manera la imaginación del profano, para quien permanece oculto el sistema gramatical vigente, que: "El pensamiento 
mítico se convierte en un intercesor, en el único medio de comunicación entre fisicos y no especialistas." (Lévi-Strauss 1992:25)

En nuestra sociedad, las proposiciones científicas en el lenguaje ordinario tienen para el profano el carácter de palabras vacuas, que no se corresponden con nada concreto acerca de lo cual pueda formarse una idea. Así, afirma el autor de Historia de Lince:

"El Big Bang, el Universo en Expansión, etc., tienen todo el carácter de mitos; hasta el punto de que, como he mostrado para éstos, el pensamiento sumido en una de estas construcciones engendra prontamente su inverso." (1992:25-26).

"De igual manera, los fenómenos que se desarrollan a escala cuántica, tal como se intenta describirlos con palabras del lenguaje ordinario, chocan tan ampliamente con el sentido común como las más extravagantes invenciones míticas" (1992:27).

Tenemos entonces, de nuevo para el hombre profano, es decir, aproximadamente la humanidad en su conjunto, un mundo sobrenatural que al igual que el de los mitos, ofrece las mismas propiedades: todo en él está fuera de su alcance y todo ocurre de manera distinta - generalmente al revés- a como ocurren las cosas en el mundo ordinario.

Se presencia de hecho, la sustitución por un 'mito científico' de los innumerables mitos religiosos que expresan el problema de los orígenes humanos; en su búsqueda por definir cómo los hombres se ven a sí mismos en su relación con el mundo, la explicación científica no elimina las versiones mítico - religiosas precedentes, sólo rechaza sus borrosidades ${ }^{18}$. No obstante el

${ }^{18}$ Desde otra perspectiva, Balandier parece arribar a conclusiones semejantes: "Hay ahí dos usos de la razón, dos lógicas, en la actualidad más reconocidas porque están más separadas. Los grandes mitos de las sociedades de la tradición dan una explicación total, afirman, dicen lo que es y lo que debe ser. La ciencia actual ya no intenta llegar a una visión del mundo totalmente explicativa, la visión que produce es parcial y provisoria. Se enfrenta con una realidad incierta, con fronteras imprecisas o móviles, estudia "el juego de los posibles", explora lo complejo, lo imprevisible y lo inédito. Ya no tiene la obsesión de la armonía, le da un gran lugar a la entropía y al desorden, y su argumentación, si bien enriquecida con conceptos y metáforas nuevos, descubre progresivamente sus propias limitaciones." (1997:10) 
efecto de sustitución permanece entre los científicos, quienes reflexionan ¿cómo alguien puede todavía creer en eso? ¿Cómo alguien se tardó tanto en darse cuenta de su error? El resto de las versiones - cuyo único defecto consiste en estar 'escritas' en otro lenguaje- se convierten en juicios ilegítimos:

"antes de que existiera la ciencia, la gente vivía en la penumbra, balbuceando verdades a medias sobre las cosas, creyendo en toda clase de mitos absurdos mezclados, afortunadamente, con muy pocas recetas prácticas" (Latour 1987)

Este tratamiento asimétrico no es exclusivo de los científicos, pues su efecto se revierte hacia la población mayoritaria al consumarse el proceso unidireccional de enseñanza, dirigido desde el interior de las redes de conocimiento hacia el público (universidades, museos, medios de difusión). Deseo relatar la siguiente imagen, con el fin de ilustrar la manera en que el público no científico hace suya esta clasificación de la actividad cognitiva.

En ocasión del reciente nacimiento de la nieta de una de mis informantes yaquis, me llamó la atención la recomendación que hacía a su hija en el sentido de tener cuidado con la culebra 'lechosa' o 'sapera' que se alimenta de la leche materna, esta culebra, prosiguió, se mete por las noches a la casa de la mujer que está amamantando, la 'duerme' e introduce la cola en la boca del lactante para evitar que llore, así, puede alimentarse de la leche de la madre. Algunas versiones de esta creencia que al parecer rebasa no sólo los límites comunitarios, sino incluso los regionales, señalan que este animal no sólo se presenta en las noches, sino en ausencia del marido (Aguirre Beltrán 1985) ${ }^{19}$ Semanas más tarde, asistí a una exposición sobre reptiles mexicanos instalada en el museo Universum en la que, para mi sorpresa, al lado de la urna habitada por una víbora de cascabel, el texto explicativo prevenía al público de rechazar la misma creencia, aduciendo que los ofidios carecen de órganos necesarios para la succión.

19 Otra creencia citada por este autor, en un contexto étnico muy distinto, refiere que "la mujer que no tiene hijos cuando muere cría víboras en el cielo, da chichi a las culebras" 
Frente a este escenario, pude reconocer el argumento de Latour en el sentido de que las preguntas sobre las causas no merecen respuesta si la existencia del efecto no se ha probado primero; o bien "equivale a preguntarse porqué un colega no te devuelve tu libro cuando de hecho no le has prestado nada!".

Con esta viñeta quiero dar pie a la afirmación de que los sistemas de explicación del mundo pertenecen a la vez a un conjunto de lenguajes, y que si en ocasiones aparecen como rivales, es porque expresan, en diferentes planos, la misma facultad de simbolización. Esta facultad general, atribuida arbitrariamente en exclusiva al comportamiento mágico, opera igualmente en el comportamiento científico, dado que uno toma posesión de los fenómenos mediante las palabras y sólo en esa medida es posible actuar sobre ellos, a partir de una imagen simbólica construida (Leroi-Gourhan 1971:321).

Así, la relación entre lógicas concretas y abstractas, lenguajes textualizados y gramaticalizados puede visualizarse en un diagrama, como los dos puntos en una espiral cuya distancia entre sí sólo es variable en cuanto al ángulo, la dirección, el movimiento y la escala en la que se sitúa el observador.

El pensamiento estructural hoy día exige un tratamiento como sistema, si se nos presenta como un discurso perfecto, la mirada estructuralista sobre él mismo debe reconocer, por el contrario, que se trata de un sistema cuyos límites son, como ya se ha mostrado para otros casos, extremadamente difusos, esto es, se trata de un sistema borroso; por ejemplo, el sistema triangular mito/ciencia/arte.

En el campo de las ciencias "duras", ciertas imperfecciones pertenecen "a la naturaleza de las cosas", cualidad a que hace referencia el principio de incertidumbre de Heisenberg. Hasta en matemáticas, las imperfecciones de naturaleza calculatoria o lógica imponen, o revelan, determinadas limitaciones o prohibiciones. Tal parece ser el caso de los llamados enunciados indecibles: la frase autoalusiva "yo miento" está en contradicción consigo misma: si miento al pronunciar la frase, entonces digo la verdad... y no miento. No podemos decidir si es verdadera o falsa, y si la ciencia consiste, como parece ser, en poder demostrar todo cuanto es verdadero en los objetos estudiados, se sabe desde 1931 por los trabajos de Godel, que tenemos prohibida esa esperanza. 
En el lenguaje ordinario no sólo tales incoherencias son comunes sino que, al parecer, dicho sistema las consiente y ello no impide la comunicación. En este sentido, si ser perfecto significa ser tan claro y unívoco como para poder ser reemplazado por una computadora, desde su inicio en el estudio de los mitos Lévi-Strauss desistió de emprender el análisis mítico con esa herramienta, al intuir, tal vez la calidad indecible de su sentencia: "los mitos se piensan en los hombres sin que ellos lo noten".

$\mathrm{Y}$ así como la evolución hubiera sido imposible sin los "errores" de replicación del $\mathrm{ADN}$, y que permiten una adaptación mejor a un entorno en transformación, los "errores" del estructuralismo que le permitirán una adaptación mejor a un nuevo entorno serán, desde mi punto de vista, el reconocimiento de la ruptura de la simetría, las oposiciones no siempre son simétricas, y por lo mismo revisten un interés superior. La aceptación de la inestabilidad permitirá la formulación del oxímoro: evolución y estructura. Reconstruir un modelo lógicamente posible con base etnográfica, tarea del etnólogo, debe tomar en cuenta que un sistema imperfecto no es un sistema contaminado, sino un sistema nuevo. 


\section{EL TERRITORIO: SIGNO METONÍMICO DE LA IDENTIDAD}

La reconstrucción del sistema ritual y simbólico de la comunidad yaqui que presentaré, inicia con la descripción del registro espacial. Dicha descripción avanza a lo largo de dos ejes: el primero consiste en el proceso de conformación histórica del territorio en el que se asienta el pueblo yaqui. Este proceso es visto aquí bajo la perspectiva de una fabricación del territorio, en el sentido de que éste no es únicamente un dato preexistente en la historia yaqui sino más bien un producto, es decir, el resultado de un esfuerzo consciente por obtener y conservar el referente identitario más importante de esta etnia. En este sentido, la disputa por la tierra reviste una importancia central en la medida en que este núcleo identitario de los pueblos yaquis, tal como lo prueban investigaciones etnohistóricas y etnológicas idóneas, es el permanente estado de contienda en lo concerniente a la posesión y delimitación de su territorio (Deeds 1994; Figueroa 1985; Hu-Dehart 1984; Spicer 1994; Voss 1982).

El segundo eje está constituido por un examen sincrónico que tiene por objeto identificar los principios de la sintaxis del espacio donde se desarrolla la vida cotidiana y la ritual. Considero que el territorio así evocado y como producto de fuerzas que aún operan, está lejos de ser un espacio virgen, indiferenciado o neutral, sólo útil como escenario para la acción social o como contenedor de la vida social y cultural. Por el contrario, se trata siempre de un espacio valorizado, sea instrumentalmente - desde el punto de vista ecológico, económico o geopolítico- o bien, bajo la perspectiva cultural que me interesa conocer: el ángulo simbólico - expresivo del espacio.

Me apoyo en la afirmación de que el territorio no es sólo uno de los elementos constitutivos del estado - nación, sino que también es el signo metonímico por antonomasia de la comunidad, de donde deriva su carácter sagrado y su inviolabilidad - so pena de sacrilegio - por parte de cualquier invasor. La referencia sobre el primer encuentro entre yaquis y españoles, basada en la crónica de Pérez de Ribas, es ahora, por la reiteración de que ha sido objeto y el tono en que se cita, una figura mítica en las palabras del etnógrafo: 
"El español pasa el Río Mayo el martes 30 de septiembre (de 1533) en busca de El Yaqui y el 4 de octubre llega a su margen izquierda y el 5 la cruza, arribando a un pueblo deshabitado cuyo nombre se desconoce; de aquí sigue el curso del río, aguas abajo y descubre un grupo de yaquis que le sale al encuentro arrojando al viento puñados de tierra, templando los arcos y haciendo señas para que se devuelvan. Son guerreros. En la vanguardia de los indios va su jefe ataviado con fastuoso penacho de plumas multicolores y concha perla; en la espalda lleva una piel de zorra también con plumas, en la cintura un taparrabo de tela de algodón y en los pies huaraches. Frente a frente los dos ejércitos, se adelanta el capitán indio en actitud arrogante y con su arco traza una línea larga en el suelo, hinca luego las rodillas y besa reverente la tierra de sus mayores; después se yergue en forma altiva y con el brazo derecho extendido invita a los castellanos a que se regresen por el camino por donde vinieron, porque de no hacerlo y si cruzan la raya, esto significa la invasión de su patria y la guerra, por lo que serán muertos sin piedad." (Fabila 1978:89-90, cursivas mías)

Esta evocación de manera alguna ha perdido su fuerza, tras siglos de conflicto armado, genocidio y diáspora, el alejamiento del lugar de origen no ha significado para los yaquis desterrados y esclavizados pérdida cultural ni 'desterritorialización' de su cultura. Por el contrario, el testimonio de hijos de yaquis enviados como esclavos a las plantaciones henequeneras de Yucatán durante el porfiriato, confirma que el viaje de retorno no es más que un periplo:

"Yo nací en Yucatán pero me quise venir a la tierra. Como no tenía dinero me vine a pie. Toda la gente que conocí en el camino me ayudó, me daban de comer y hasta para algunos pasajes. Todos me trataron bien, hasta que llegué a Sonora, aquí ya nadie me ayudó, cuando les decía que era de la tribu (yaqui), me hacían mala cara." ${ }^{11}$

$\mathrm{Y}$ así como los migrantes llevan a cabo en su lugar de destino una reterritorialización simbólica de la cultura de origen y hacen un esfuerzo por recuperar $\mathrm{y}$ reconstruir in situ los geosímbolos de la tierra natal; al

\footnotetext{
${ }^{1}$ Testimonio recogido en Las Guásimas en agosto de 1988.
} 
reencontrarse con su territorio, los yaquis procedieron en sentido inverso: reconstruyeron en su territorio ancestral los nuevos barrios, geosímbolos de su destierro, tal como lo recuerdan los barrios "Merideños" y "Tlaxcala" en Pótam.

Así, la reconstrucción del proceso que tiene como objeto el primero de los ejes de análisis propuestos, reposa en el hecho de que los trabajos de carácter etnohistórico sobre los yaquis han alcanzado tal magnitud y relevancia que permiten proveer de un marco propio y retomar los trazos más relevantes que definen ese aspecto (Figueroa 1985; Hu de Hart 1981; Spicer 1962 y Voss 1982). De manera que mi perspectiva concéntrica parte de la índole más general, la región del noroeste de México, pasando por la propiedad comunal yaqui, hasta alcanzar el nivel del poblado en el que se desarrolló la investigación de campo.

Tal como ya existe en buena medida para Mesoamérica y el Gran Suroeste 2 , no se ha construido un concepto aceptable y bien establecido que comprenda el noroeste de México. Su situación geográfica intermedia -una superárea que abarca del valle de San Miguel Culiacán hasta el área conocida como la cultura Trincheras al norte- determina en gran medida la perspectiva que se tiene de la zona como también, culturalmente intermedia. La presencia tanto de aspectos mesoamericanos como de la región septentrional entre los grupos nativos de este extenso territorio, ha planteado a los investigadores no pocos problemas que desembocan, en la mayoría de los casos, en la apreciación de sólo una de las caras de la moneda: la definición de la frontera norte de Mesoamérica (Broda 1991:xiv). Por su parte, la comparación con los pueblos indígenas septentrionales, sobre todo los pueblo y navajo del suroeste y los indios de las llanuras, no se ha retomado desde los importantes intentos llevados a cabo hace ya más de cincuenta años por Parsons (1939).

Frente a este orden, quedan pendientes varias cuestiones que deberán ser resueltas por la investigación etnográfica, arqueológica y filológica de los grupos de las familias lingüísticas que prevalecen en la región: la yutonahua o

2 Generalmente descrita por investigadores de habla inglesa como The Southwest o Greater Southwest, se trata de un área con bases culturales y medioambientales definida por su población de cazadores - recolectores y agricultores de las tradiciones pueblo y Sonora-Gila-Yuma (Villalpando 1991:33) 
utoazteca y la pimana, considerando su especificidad cultural y reconociendo que su pertenencia a una u otra área se define a posteriori.

Parto del hecho de que las etnias que componen la familia lingüistica utoazteca ocupan al menos dos áreas, la mesoamericana y la oasisamericana. Áreas cuyas fronteras no son impermeables y cuyo establecimiento se debe a un intento de Kirchhoff (1967) por sistematizar la concurrencia de determinados rasgos, más que a fundar una tipología. $Y$ en este sentido es obligatorio considerar la vecindad de estos grupos en ambas direcciones: entre el "Gran Suroeste" y la superárea mesoamericana.

Por su parte, el concepto de tradición religiosa mesoamericana acuñado por López Austin alude a la congruencia global inferida de fuentes antiguas y actuales que corresponde a una misma corriente histórica ubicada en la dimensión de la larga duración: religión mesoamericana y religiones coloniales. No se trata de un mismo conjunto de formas de pensamiento o cosmovisiones, no obstante, afirma este autor: "en los estudios del mito es prioritaria la reconstrucción del contexto de las creencias mitológicas. Éste debe tratar de reconstruirse a partir de las fuentes más explícitas, y hoy lo son, precisamente, las fuentes documentales que se refieren a los pueblos nahuas del Altiplano Central" (López Austin 1989:93).

Este procedimiento ya ha sido probado con validez en las investigaciones relativas a los petroglifos del Norte de México y de los sistemas astronómicos del suroeste de Estados Unidos ${ }^{3}$. La conexión mesoamericana se afirma sobre el conocimiento que se tiene de los grupos de la Meseta Central, lo que ha permitido la identificación de las peculiaridades del Gran Suroeste como un conjunto de sistemas con ausencia de: a) calendarios escritos b) sistemas numéricos de cuenta larga c) "años" de 260 días y d) año bisiesto; todo ello asociado a una mayor indefinición entre las temporadas de secas y lluvias (Zeilik 1991:545).

Como se observa, la definición negativa o por ausencia parece ser la constante en lo referente a las observaciones sobre el Noroeste, no obstante, con base en

${ }^{3}$ Verbigracia los sitios de El Zape en Durango, y La Proveedora y Calera, Sonora (Broda, et.al. 1991) 
los estudios de la lingüística histórica, Hill (1992) reconstruye un sistema ritual propio de los pueblos de lengua utoazteca creado a partir del concepto de flor, dicho sistema es identificado por la autora aún en antiguas fases de desarrollo de la comunidad de habla, lo que le permite proponer un patrón común de representación del mundo entre los grupos nativos aludidos.

Este complejo cromático identificado como el mundo $f l o r^{4}$, dada su significación y distribución entre los utoaztecas, sugiere un origen septentrional y además de estar presente entre las lenguas utoaztecas sureñas, se encuentra en el hopi; las lenguas numic manifiestan algunos aspectos del complejo, y en menor número, las lenguas takic. Si esta conexión se ha probado en el nivel lingüístico, el punto de vista histórico confirma las distintas formas como tuvo lugar la conformación de la identidad de las comunidades indias del noroeste y de los yaquis en particular.

Este proceso acumulativo y de crítica sobre el cual se ha construido el conocimiento sobre el pueblo yaqui es producto del proceso histórico de reconocimiento de la relación entre este pueblo y los textos que las sociedades novohispana y mexicana produjeron como resultado de su interacción histórica. Parto del principio de que dichos textos representan procesos sociales y políticos, pero también una cosmología, aquélla que los ampara ${ }^{5}$.

Identifico tres momentos de este proceso: el primero (1525-1767), producto de los primeros encuentros frente a las expediciones militares y la permanencia de la misión jesuita, termina justamente el año del extrañamiento que Carlos III decretara a la Compañía de Jesús. En este periodo tiene lugar el proceso fundador de la misión y del agrupamiento alrededor de los ocho pueblos.

4 Las características de este complejo son, entre otras, la evocación cantada, no narrada; la representación de la tierra y del aspecto espiritual del pueblo, animales y objetos; presencia del símbolo del corazón humano y la sangre; la asociación con el fuego, la fuerza y espiritualidad masculinas, y en menor medida con la femineidad.

5 Esta investigación se basa en un registro de 303 títulos sobre yaquis de Sonora y Arizona que comprende libros, tesis, artículos, ensayos, reportes o notas periodísticas relevantes; escritos y editados entre 1525 y 1990, publicada en María Eugenia Olavarría, Símbolos del desierto, Colección Texto y Contexto núm. 10, UAM Iztapalapa, 1992. 
El hito representado por esta fecha marca el segundo momento (1767-1936) que abarca, desde la presencia de la orden franciscana y el inicio de la Guerra del Yaqui, hasta la publicación de los decretos presidenciales que restituyen parte de su territorio tradicional al pueblo yaqui. Este período es de importancia crucial en la conformación del espíritu identitario y marca los rasgos más importantes de su carácter.

El tercer momento (1936-1997) corresponde a la etapa de estabilidad alcanzada a partir de la reocupación del territorio, reintegración de los ocho pueblos y el restablecimiento de una organización social y ritual. El conocimiento sobre este período, del cual sienta las bases la obra de Lumholtz, se ve fortalecido por la actividad de investigadores mexicanos, franceses, alemanes y estadounidenses, entre quienes se distinguen Ralph Beals y Edward H. Spicer. La publicación en 1980 de la sintesis del trabajo que Spicer dirigió a lo largo de cincuenta años The Yaquis: A Cultural History y la abundante producción que se ha realizado en las últimas dos décadas, definen la situación contemporánea. 
Sobre este periodo existe una crónica jesuítica de valor extraordinario: la Historia de los triunfos de nuestra Santa Fe entre gentes las más barbaras y fieras del nuevo orbe (1645). Su autor, el padre Andrés Pérez de Ribas ingresó a la Compañía de Jesús en 1602 y en 1604 pasó a México y luego a Sinaloa, iniciándose entonces su acción evangélica en las misiones entre los ríos Fuerte y Yaqui, las que hubo de abandonar a fines de 1619 ó 1620. Su obra abarca sucesos entre 1591 y 1644, divididos en doce libros dedicados tanto a la descripción de los grupos étnicos de Sinaloa como a la acción misional así como a la crónica de la rebelión de los tepehuanes en 1616. El libro quinto está dedicado a la evangelización de los yaquis y en el séptimo se justifica y defiende esa labor misionera. Describe los grupos indígenas, sus fuentes de alimentación, su vestido y su vivienda, sus métodos de cacería y pesca o sus faenas agrícolas, sus costumbres guerreras, su religión y hechicería, sus chamanes y caciques. En el capitulo final de su Crónica, Pérez de Ribas esboza la ulterior historia de la evangelización jesuítica hasta 1654. Mas tarde, tomaría en sus manos este mismo asunto corrigiéndolo y completándolo el padre Francisco Xavier Alegre en 1754.

A este periodo también corresponden el no menos valioso libro del padre Ignaz Pfefferkorn Descripción de la provincia de Sonora, (1794-1795) así como la obra de un anónimo que se supone sea el padre Juan Nentvig, el Rudo ensayo, que data de 1763.

Estas fuentes reflejan el hecho de que, a su llegada al norte de México, prevalecía desde el punto de vista externo, una confusión entre unidades lingüisticas y culturales y entre la adscripción local o parental y étnica. Los misioneros crearon o adoptaron un número de categorías específicas para etiquetar a los distintos grupos indios locales; no generaron nuevas categorías étnicas sino que incorporaron las identidades tribales a un esquema de clasificación étnica preexistente, derivado de su experiencia en el siglo precedente. Este esquema clasificatorio poseía una dimensión práctica que contribuyó a su persistencia e inflexibilidad (Deeds 1990; Radding 1979). 
En el reconocimiento de las identidades étnicas del noroeste de México, proceso que perduró hasta los siglos XVIII y XIX, algunos grupos desaparecieron y otros sobrevivieron, en muchos casos no se han identificado las causas de estos procesos culturales y étnicos tan disímbolos, dado que no se trata únicamente de una simple dicotomía entre la incorporación y la sobrevivencia, sino de procesos complejos de resistencia, apropiación, subversión y reinvención.

Bajo tales circunstancias, la información sobre el pasado prehispánico yaqui no permite hacerse una idea objetiva y completa de la vida de ese pueblo antes de la llegada de los españoles. La arqueología ha proporcionado sólo elementos que confirman las informaciones de los cronistas, los cuales se limitan a señalar la hipótesis en torno al arribo tardío de los yaquis a los valles fluviales y que se trataba de agricultores seminómadas que complementaban su actividad con caza, pesca, recolección y la guerra contra sus vecinos.

De manera que durante el período histórico del contacto y la situación colonial tuvieron efecto tres procesos: 1) transformaciones en los esquemas de clasificación étnica de indios y españoles 2) reducción en el número de identidades indias y 3) asociación de identidades surgidas a lo largo de la Colonia con distintas áreas geográficas. Como producto de la interacción entre las perspectivas interna y externa, la identidad es un problema clasificatorio que cambia cuando lo hacen las circunstancias individuales y grupales, estudios etnohistóricos muestran cómo las etnias subordinadas llegaron a negociar y renegociar sus contratos y vínculos con la clase dominante y hasta llegar a la manipulación de la identidad social mediante el cruce de categorías étnicas. Si se toma en cuenta que la población número llegó a su punto más bajo alrededor de 1650 debido, entre otras causas, al contacto colonial temprano y continuo, la alta mortandad en sus rebeliones y epidemias y la inhumana explotación que sufrieron durante su concentración en minas; el aumento en el número de residentes de las misiones era debido mayormente a la incorporación de mestizos, mulatos y migrantes mayos provenientes de la costa de Sinaloa.

Para fines del XVII la población número de estas áreas había declinado en un $90 \%$ respecto del nivel prehispánico, tal descenso demográfico volvió a recuperarse muy tardiamente, ya que muchos indios se integraron 
eventualmente en la sociedad mestiza en la regiones más colonizadas. En la segunda mitad del XVIII, la población número se contrajo en comparación al resto de la población y las comunidades "indígenas" eran étnicamente mezcladas, es en este momento que emergen categorias más inclusivas de etnicidad, tomando la lengua como el principal criterio de adscripción, lo que trajo como consecuencia la reducción en el número de grupos indios documentados entre los siglos XVII y XVIII.

Esta reducción del número de distinciones étnicas refleja el hecho de que los misioneros entendieron mejor el carácter de las agrupaciones étnicas y estaban mejor capacitados para reconocer las similitudes culturales y lingüísticas entre ellos. Aunado al hecho de que las identidades indias no dependían por completo de estructuras y fuerzas externas para su persistencia, por el contrario, se reproducían siempre hasta cierto punto intencionalmente, por los propios indios en la búsqueda de sus metas e intereses.

Los pueblos indígenas de Sonora constituyeron aldeas y rancherías pobladas por diferentes grupos étnicos con una larga tradición agrícola, principalmente los ópatas, eudeves y pimas. En el noroccidente el tributo y la distribución forzosa de bienes no figuraron en las relaciones entre indios y españoles; en cambio, el trabajo asalariado y la movilidad espacial entre pueblos, minas y estancias dieron pie al proceso de mestizaje y al conflicto. La forma característica de asentamiento en Sonora, las rancherías esparcidas, constituyó una forma eficaz de huida de las misiones y de resistencia contra el control militar de los españoles. Al competir españoles e indios por los recursos cada vez más escasos de tierra, agua, monte bajo y pasturas, se les hizo más dificil a las comunidades mantener su economía comunal agraria. Esta nueva definición de la propiedad, aunada a la división de los indígenas entre "ciudadanos" y "los de campana", dio lugar a largo plazo al conflicto que marcaría la tónica de la relación entre "vecinos" e "indios" (Radding 1979 y 1992).

Las características de la población número determinaron en gran medida la manera en que se desarrollaron los primeros enfrentamientos entre indios y españoles, puesto que al no poder ser establecida una institución como la encomienda, el exterminio se perfiló como la alternativa para los blancos ansiosos de apropiarse de ese territorio feraz. Durante este período se llevó a 
cabo la 'reducción' de los yaquis a los ocho pueblos tradicionales con éxito tal que esta organización territorial fue considerada sagrada y es impensable, hasta la fecha, la fundación de un nuevo pueblo cabecera así como la desaparición de uno de los mismos. La instrucción religiosa también fue realizada eficazmente, prueba de ello es la institución del temastian, cargo que se conserva hasta nuestros días. A partir de entonces se introdujeron, junto con la ganadería, cultivos europeos como el trigo y legumbres, con los cambios tecnológicos correspondientes.

En las misiones el trabajo estaba reglamentado: tres días se trabajaba en los bienes de la misión y tres días en las propias tierras, el séptimo día se dedicaba al culto cristiano. Bajo este régimen y presionados por los blancos para apoderarse de ese territorio y para usar a los indígenas como mano de obra barata, los yaquis se sublevaron. En 1741 se produce un levantamiento encabezado por Ignacio Muni, Calixto, Baltasar y Esteban que terminó con la firma de un tratado en que se reconocía el derecho de los yaquis a conservar sus costumbres y gobierno, que no debía ser ejercido más que por individuos de su grupo, la posesión total de sus tierras y el derecho a conservar sus armas. Estas rebeliones de "primera generación" eran intentos milenarios de restaurar una cosmología balanceada en el sentido número y fueron dirigidos por líderes militares y chamanes. 
Al poco tiempo, la expulsión de los jesuitas en 1767 concluyó con este período de paz relativa; sus obras fueron casi todas escritas en el destierro y publicadas en el extranjero. Con la fundación de misiones franciscanas entre 1769 y 1823 se intentó mantener el control de la liturgia, pero sin el éxito de sus antecesores $\mathrm{y}$, en cambio, se ejerció menor influencia en el ámbito económico, introduciendo a los yaquis en una de las problemáticas principales de su historia: la pérdida de su territorio a manos de colonos.

En este período se editó en 1787, la Historia de la vida y apostólicas tareas del venerable padre fray Junipero Serra... por fray Francisco Palou, donde las noticias etnohistóricas son escasas y abundantes las referentes a la evangelización. De gran importancia, en cambio, es la Crónica seráfica y apostólica del Colegio de Propaganda Fide de la Santa Cruz de Querétaro (1792) de fray Juan Domingo Arricivita en la que hay datos etnográficos sobre los indios de California, Sonora - Arizona, Chihuahua y Nuevo México, Coahuila y Texas, y sobre grupos del sur como los lacandones. Continuó Francisco Xavier Alegre con su Historia de la Compañia de Jesus en Nueva España (1841-1842).

Con el fin de la tutela jesuita y en el marco de las guerras de Independencia, y en medio del desorden político que como consecuencia imperaba en Sonora, los yaquis presenciaron indiferentes la insurgencia y para 1825 se inician las rebeliones que de ahi en adelante marcarán la tónica de las relaciones con los regímenes que se sucedieron en la República Mexicana hasta una fecha tan tardía como 1936. Este período es ubicado por otros autores como el conjunto de acontecimientos bélicos ocurridos a lo largo de 400 años en ambas márgenes del río Yaqui y en sus inmediaciones, desde Guaymas hasta la desembocadura del Mayo. Si se toma en cuenta que en 1533 ocurrió el primer encuentro entre los yaquis y los yoris, y no habrian de cesar los antagonismos sino hasta 1937, cuando Lázaro Cárdenas dictó el Acuerdo para Resolver el Problema Agrario de la Región del Yaqui, por el cual fueron reconocidas 500 mil hectáreas, 20 mil de ellas de riego; estas rebeliones constituyen la más larga historia particular de la lucha armada de un pueblo por mantener su territorio. 
Este período reportado por Francisco P. Troncoso en Las guerras con las tribus yaqui y mayo (1977 c.1905) constituyó para este grupo un proceso de merma demográfica, pérdida de su territorio y desajustes políticos que fue aprovechado por la oligarquía para continuar con la colonización del Valle mediante el deslinde y repartición de las tierras; pero fue también, sin embargo, la etapa en que se conformaron rasgos que determinaron la aún presente corporatividad del grupo frente a los embates de la sociedad mayor ${ }^{6}$.

La primera de estas rebeliones fue encabezada por Ignacio Jusacamea, alias Juan Banderas, quien proclamó en 1825 la independencia de la "Confederación India de Sonora" e imitando al cura Hidalgo, tomó como insignia la Virgen de Guadalupe. Pero fue procesado en 1832 al igual que los jefes ópatas Virgen y Dolores Gutiérrez después de la derrota de los indios a orillas del río Buenavista. En estas guerras los nativos usaron por primera vez las armas europeas.

Otra insurrección de importantes dimensiones, esta vez con la participación de los pimas, tuvo lugar veintisiete años después, y no fue sofocada sino hasta el exterminio casi total de yaquis y mayos en 1868. Esta situación predominó hasta 1875 con la campaña de José María Leyva Cajeme que terminó después de una dura ofensiva. En 1887 este líder fue capturado y ejecutado. No obstante los yaquis mantuvieron la lucha guerrillera con un nuevo jefe, Juan Maldonado Tetabiate que continuó hasta 1897 , año en que se llega al acuerdo de paz, mismo que no fue respetado por las autoridades. Se inician nuevos brotes de violencia que rápidamente son sofocados por un ejército muy superior a las fuerzas yaquis. Muerto Tetabiate en 1901 le suceden los jefes Luis Bule, Ignacio Mori, Luis Espinoza y Luis Matus.

${ }^{6}$ En la primera obra importante sobre los yaquis, Andrés Pérez de Ribas anota una población de 30,000 indios, y desde esta fecha --alrededor de 1533-- a 1830 esa cifra descendió a 12,000 habitantes. Después de 1830, período que corresponde a las Guerras del Yaqui, el fenómeno es todavía más cruel puesto que en poco menos de 60 años - 1830 a 1887-- sólo quedaron 4,000 yaquis en el Valle. Hasta fines del siglo XIX continuó la diseminación de hombres en todo Sonora y los Estados Unidos, situación que no disminuyó sino hasta 1905 en que se registran 18,000 habitantes. Un nuevo descenso tuvo lugar con las deportaciones masivas y las guerras revolucionarias y para 1930 sólo había 8,500 habitantes. 
Durante el Porfiriato se intensificó la ofensiva genocida y miles de yaquis fueron deportados a Yucatán, Quintana Roo y Tlaxcala y vendidos como esclavos. Los que lograban huir se refugiaron en Arizona, Estados Unidos, donde hasta la fecha residen sus descendientes en los poblados de Pascua, Guadalupe y Barrio Libre.

Durante la revolución, los yaquis, cuya unidad estaba amenazada por la represión, pudieron afirmar su presencia en el momento en que su fuerza guerrera fue solicitada. Es conocida la participación de los yaquis en el conflicto revolucionario, su intervención fue definitiva en la lucha constitucionalista cuyo jefe había prometido la restitución de su territorio al final de la guerra. Sin embargo, al no cumplirse la promesa por parte de Alvaro Obregón, se desata un nuevo levantamiento que se prolonga hasta fines de 1929, cuando Emilio Portes Gil firma un convenio de paz con el grupo. De esta fecha data la incorporación al servicio militar de manera obligatoria y su confinación al ribazo norte donde vivieron bajo la vigilancia del ejército hasta 1936. La división entre militaristas o colaboradores con el ejército constitucionalista y civilistas o broncos permitió a estos últimos dar a conocer sus reivindicaciones y también aparecer como obstáculo a la lógica económica, según la cual las tierras del Valle del Yaqui debían ser explotadas en forma masiva con los métodos modernos. Durante los conflictos armados la agricultura sólo era practicada por los indios pacificados, mientras los "broncos" alternaban su actividad guerrera con trabajo como peones en las haciendas.

Con la política de Cárdenas se puso fin a los enfrentamientos armados y comenzó una nueva etapa de reintegración, cuyos primeros efectos fueron el retorno de cientos de yaquis a su territorio. A partir del decreto presidencial de Lázaro Cárdenas, el 27 de octubre de 1937, la tribu fue dotada de 485,236 has., las cuales adquirieron la forma de propiedad comunal. Alrededor de 100,000 has. susceptibles de cultivo, aunque sólo se habilitaron cerca de 33,000 has. para tal fin. Sin embargo, también como parte de los acuerdos de 1937, sufrieron la pérdida de dos poblados tradicionales que quedaron en manos de población mestiza, Cócorit y Bácum, restableciéndose los ocho con la fundación de Loma de Guamdchil y Loma de Bácum. 
Tercer Momento (1937-1997)

En este período tiene lugar uno de los procesos definitorios para el grupo, que consistió en la restitución parcial de su territorio y la firma de los tratados de paz con el gobierno federal. Este acontecimiento impuso una tónica totalmente inédita a la vida comunal y posibilitó el acercamiento de investigadores profesionales por temporadas de estudio más prolongadas en la zona.

Tomando como antecedente las investigaciones de Carl Lumholtz (1984 c.1904), los estudios sistemáticos en la zona inician en la década de los treinta con los trabajos de los norteamericanos Ralph Beals (1932) y E.C. Parsons (1939). De 1934-35 data la descripción del rito de Semana Santa por el poeta yaqui Refugio Savala ${ }^{7}$, y hacia 1940 Edward H. Spicer hace la etnografia de las comunidades yaquis de Arizona. Ese mismo año Carlos Basauri y Alfonso Favila publican trabajos monográficos sobre las comunidades sonorenses. Bajo la formación de Beals y Spicer en la década de los cuarenta salen a la luz estudios sobre aspectos específicos de la sociedad y cultura yaquis como el de Wilder, C.S., (1940) sobre la danza del venado y el de Ruth Warner Giddings (1942-43) sobre literatura oral; así como el del propio Spicer sobre el territorio yaqui (1945).

En los cincuenta la tendencia hacia los estudios monográficos y temáticos se fortalece con las publicaciones de Muriel Th. Painter (1950), Edward H. Spicer (1954) y Ruth W. Giddings (1959). La corriente de estudios sobre la historia de los pueblos indios o historia cultural sienta sus bases con la aparición en 1962 de Cycles of Conquest: The Impact of Spain, Mexico, and the United States on the Indians of the Southwest, 1533-1960 de Edward Spicer, cuya obra culmina con la publicación en 1980 de The Yaquis: A Cultural History.

En este período se ve incrementada la aportación en cantidad y calidad al conocimiento de sistemas como el musical y dancístico (Varela 1982; Larry Evers y Felipe S. Molina 1987; Snyder 1989; Olmos 1998), el de la identidad

7 Reproducido en el artículo de Spicer y Beals con leves cambios de puntuación y sintaxis (Spicer, Rosamond B. y Dorothy Beals en Crumrine y Spicer en prensa). 
étnica (Figueroa 1985,1994; McGuire 1986), el simbolismo y la mitología (Muriel Th. Painter 1986; Olavarría 1989,1992; Schechner 1988) o bien la dimensión histórica y etnohistórica (Camou 1985; Gouy-Gilbert 1983).

No obstante, nuevos problemas surgieron a partir de la creación, en 1940, del distrito de riego núm. 18 Colonias Yaquis; actualmente esta zona pertenece administrativamente al Distrito de Desarrollo Rural núm. 148 Cajeme: las diferentes instituciones oficiales comenzaron a llevar a la práctica planes de desarrollo agrícola, se fundan las sociedades de crédito y se aleja a los yaquis de la toma de decisiones sobre la producción. Con la construcción de la presa de la Angostura (1941) y la del Oviachic (1945) se acabaron las inundaciones periódicas que los pobladores nativos aprovechaban para cultivar, desde antes de la llegada de los españoles y también se perdió el río como recurso indispensable para su producción. Hasta los años cincuenta los yaquis se vieron obligados a abandonar sus tierras de cultivo y buscar empleo en la construcción de la presa o migrar hacia los centros urbanos de la entidad. Esta situación empeoró con el alemanismo, pero más tarde, con la construcción de canales se recuperó el líquido y se repoblaron los ocho pueblos tradicionales. La modernización imperante de este período se vió reflejada en la relación de jornalerismo en su propia tierra que generó la intervención del Banco de Crédito Ejidal, provocando que la situación económica se deteriorara a fines de los cincuenta ${ }^{8}$. Como alternativa se fundaron las cooperativas pesquera y ganadera con sede en Guásimas y el rancho Aguacaliente, respectivamente.

La dependiente situación económica así generada contrasta con la autonomía política, que ya para la fecha habían ganado los yaquis; a pesar de la continua presión ejercida por los productores no indígenas de la margen izquierda del río y la tensión que se produjo en los setenta con motivo de la invasión de sus linderos, esta etnia cuenta con un gobierno tradicional efectivo que no duda en reclamar sus demandas ante el gobierno estatal y federal.

Los conflictos territoriales no han dejado de ocurrir, actualmente, la lucha de los yaquis se ha centrado en la definición de la frontera sur de su territorio y

B A principios de la década de los ochenta había en el territorio yaqui 225 sociedades de crédito que trabajaban con el Banco Nacional de Crédito Rural, el $60 \%$ de las familias pertenecían a alguna de ellas y tenían una parcela como dotación. 
sobre el control de los recursos marinos. Este proceso alcanzó un momento álgido en los eventos de la década de los setenta, cuando la tribu yaqui, los campesinos organizados en torno al partido oficial y la élite terrateniente de Ciudad Obregón, protagonizaron la lucha por la obtención y posesión de tierras. El saldo de esta movilización resultó negativo para los yaquis, mientras que los campesinos tutelados por el PRI fueron favorecidos con la expropiación.

La intención de socavar la autonomía política y la integridad del patrimonio ancestral de los yaquis no ha cesado por parte del gobierno, con la fundación en 1973 de un Centro Coordinador Indigenista en Cárdenas, Río Yaqui, el cual se trasladó posteriormente a Vícam Estación, bajo la doctrina indigenista entendida como función asistencial, y llevó a cabo los programas que normalmente ofrece a los grupos indígenas; sin embargo, en virtud de las características de la tribu yaqui que no acepta políticas paternalistas y al cabo, autoritarias, los yaquis solicitaron el cierre del mismo en septiembre de 1990.

En 1983 el pueblo yaqui, a través de sus autoridades y organizaciones, decide, después de hacer un balance socioeconómico y de identificar como un problema la "modernización", formular un plan de desarrollo propio conocido como "Plan Integral de Desarrollo de la Tribu Yaqui" PIDTY. Después de un proceso de negociación, en 1985 el gobierno federal y estatal reconocen el PIDTY y destinan recursos financieros para apoyarlo. Con la creación de los Consejos Sectoriales de Producción, Servicios y Bienestar Social bajo la supervisión de las Autoridades Tradicionales, la tribu yaqui establece un esquema organizativo que le permite tomar decisiones conscientes $y$, hasta cierto punto, autogestivas, situación sui generis en el ámbito de las relaciones interétnicas en México.

El impulso que este programa ha traído consigo, se refleja en un conjunto de organizaciones que operan de manera coordinada con las formas de gobierno tradicional, entre otras, el Fideicomiso para el Desarrollo de la Tribu Yaqui, el Centro de Informática de la Tribu Yaqui, el Programa de Organización y Capacitación, Archivo y Cultura, Jóvenes Yaquis y el Programa de Fomento al Deporte.

La estrategia gubernamental hacia las comunidades yaquis para esa fecha se 
centró en la puesta en marcha del Programa de Asistencia Técnica Integral para la Comunidades Yaquis (PATICY). Este programa no es otra cosa que la entrega de sustantivo apoyo presupuestario federal y estatal, pero que por carecer de mecanismos idóneos de reparto, seguimiento y evaluación, derivó en detonador del divisionismo y origen de gran parte de la violencia que afectó a la zona durante la presente década.

Lo que en teoría debía ser decidido conjuntamente por los gobernadores de los Ocho Pueblos, la Secretaría de la Contraloría del Estado, SEDESOL y el Gobierno de Sonora derivó, cuatro años más tarde, en un conflicto que llevó al gobernador de Pótam a un hospital de Ciudad Obregón con heridas de bala, después de acusar a varios profesores de haberse enriquecido con fondos del PATICY quienes, aseguró el denunciante, contaban con el apoyo del gobernador Manlio Fabio Beltrones. Posteriormente a la balacera en la que participaron beneficiarios del PATICY y resultó herido el gobernador yaqui, autoridades municipales y estatales decidieron que un grupo de 30 agentes de la Policía Judicial Estatal debía vigilar el acceso a Pótam.

Las nuevas técnicas del gobierno priísta, que no se diferencian de las utilizadas en otras regiones indígenas del país, parecen estar obteniendo lo que cuatrocientos años de conflicto armado no lograron, el resquebrajamiento de la unidad interna, la pérdida de la confianza en las autoridades tradicionales y el avance de la corrupción. No en vano el Frente Mexicano Pro Derechos Humanos denunció ante la Secretaría de Gobernación que Beltrones "para confundir a la opinión pública dio el nombre de guardias tradicionales de la tribu yaqui a fuerzas criminales que atacan a los pueblos yaquis y que también creó un instrumento de pillaje y saqueo denominado PATICY que en realidad nada beneficia a la etnia".

Aunado a esta situación, se rumora la presencia de narcotraficantes en la zona y de plantíos en Llano Prieto, Boca Abierta y Belem, así como en el otrora mítico Cerro Omteme. Se cuenta que, cuando en 1990 cayó una avioneta en el poblado pesquero de Las Guásimas, ésta duró abandonada varios días, hasta que algunos curiosos encontraron paquetes con cocaína, los cuales, dicen, fueron canjeados por instrumentos de labranza. Pero es posible que no se trate únicamente de rumores, es un hecho que el clima de tranquilidad que reinaba se ha perdido, tanto que en noviembre de 1996 el Consejo Tradicional de los 
Pueblos Indios tuvo que firmar un convenio con el gobierno estatal para hacer frente al narco.

Frente a este panorama, la defensa contra los abusos del gobierno ha tomado otra dirección, se han hecho más frecuentes las tomas de predios, la obstaculización de la carretera federal y los bloqueos a obras. Con pleno sentido de la justicia, los yaquis consideraron incongruente que por su territorio se construyera una obra con el objeto de conducir agua para los turistas de Guaymas y San Carlos, cuando ellos carecen del líquido para sus requerimientos básicos. Hay pueblos como Belem que carecen de agua desde hace 20 años y la obtienen de charcos y pozos. En Guasimitas, Huírivis, Rahum, Tetabiate, Compuertas, Lencho, Cárdenas, Chumampaco y Puerto Lobos sus habitantes beben y usan agua contaminada con agroquímicos que se vierten en los canales de riego. Ante esta situación, en julio de 1993 rechazaron los ofrecimientos presentados por SEDESOL y decidieron continuar el bloqueo de las obras del acueducto Yaqui-Guaymas, dejando sin líquido a las ciudades de Empalme y Guaymas.

Cabe señalar que tales medidas se toman como un recurso extremo, dado que sus relaciones con el gobierno se resumen en el dicho caita confianza o sea, "no hay confianza" puesto que tan sólo reclaman el cumplimiento de un convenio firmado desde 1990, en que se había establecido el compromiso, entre otros, de satisfacer la introducción de agua potable para $40 \mathrm{mil}$ habitantes. En este tenor, en agosto de 1995, 200 pescadores yaquis tomaron las oficinas de la SEMARNAP en Guaymas en demanda de la autorización de salir a pescar camarón antes que los barcos particulares, quienes sólo dejan a los cooperativistas yaquis las migajas de la pesca en su propio territorio marítimo.

Frente a este panorama y ante la nueva presencia que los pueblos indios adquirieron en el contexto nacional a partir de 1994, el 11 de enero de 1997 el presidente Ernesto Zedillo ordenó "descongelar" la expropiación de tierras decretada desde 1937 por Lázaro Cárdenas. Según el decreto, serían $485 \mathrm{mil}$ hectáreas las que debían entregarse pero finalmente fueron $452 \mathrm{mil}$, por el resto, o sea por 33 mil hectáreas, los yaquis recibieron una indemnización equivalente a 40 millones de pesos. Obviamente este monto, del que la tribu yaqui era acreedora, se les retribuyó en forma de inversión federal en 
beneficio de la tribu y el gobernador Beltrones apareció como promotor de un Programa Especial de Salud, Agua Potable e Inversiones de Alianza para el Campo.

No todos los yaquis reconocieron como justa esta resolución. Según el Consejo de Autoridades Tradicionales de Pueblos Indios, organismo que agrupa a las etnias sonorenses dirigido por el yaqui Lorenzo García, el área reclamada era originalmente de 512 mil hectáreas, ya que este acuerdo no contempla 20 mil has. en la sierra del Bacatete actualmente ocupadas por pequeños propietarios y ejidatarios y otras tantas en el ejido Las Guásimas.

A un año de haber aceptado el acuerdo, en enero de 1998 los yaquis tomaron posesión del dren colector para evitar que los barcos particulares continúen aprovechándose de sus recursos; asimismo demandaron la restitución de los terrenos de La Cuchilla e Isleta. En febrero, un grupo de yaquis desalojó a los policías municipales de Vícam, bajo el argumento de que "ellos pueden vigilarse solos", la autoridad municipal de Guaymas pidió de inmediato la intervención del gobierno estatal en lo que calificó una situación de riesgo porque "los yaquis se han dedicado a amedrentar a los policias, a exigir cobro de impuestos que corresponden al Ayuntamiento y a sostener un clima de tensión."

La solicitud de intervención estatal para restablecer el orden en Vícam dió pie a la intervención de la Policía Judicial Estatal y del ejército en la zona, presencia que fue aprovechada para decomisar armas propiedad de la Guardia Tradicional. Así, la estrategia del gobierno ha surtido tal efecto que los conflictos internos que se venían gestando desde los ochentas ahora se presentan como ingobernabilidad, y se justifica la intervención del ejército cuando las propias las autoridades tradicionales afirman que son los grupos paramilitares protegidos por el gobierno estatal los que ocasionan la división interna: el conflicto entre los bajecas y los paticys ha llegado a un punto tal que el Congreso Estatal se declara incompetente para auditar el PATICY.

Lo que verdaderamente se discute no son los resultados prácticos de la autonomía que desde hace más de medio siglo consiguieron los yaquis, tras luchar por ella a sangre y fuego, sino el supuesto de que la autonomía número - tal y como la demanda el EZLN - es contraria a la "unidad nacional". En el 
nivel del discurso, queda de manifiesto una incompatibilidad entre las demandas de autonomía de los pueblos indigenas y la integridad nacional. La relativa autonomía y capacidad autogestiva yaquis no han puesto, para nada, en peligro la unidad nacional mexicana a pesar de que una parte de la comunidad yaqui se encuentra al otro lado de la frontera.

El gran potencial económico que representa el territorio de los yoremes es considerado como un recurso desaprovechado por los empresarios agrícolas de la región. En efecto, la situación económica de la familias yaquis desde el punto de vista productivo es desfavorable en todos sentidos. A pesar de que su aparente bienestar contrasta con la pobreza extrema imperante en la mayoría de las regiones indígenas del país.

A diferencia de la mayoría de los grupos indígenas del país, la actividad agricola se desarrolla de manera intensiva, completamente integrada a las economías regional y nacional. Durante los últimos quince años, esta actividad se ha sustentado en un patrón basado en los cultivos de trigo, ajonjolí, cártamo y soya , sólo en años recientes el cultivo de maíz ha recobrado importancia.

Hasta hace unos años, obtenían financiamiento de dos fuentes principales: BANRURAL y Solidaridad; sin embargo en el mismo PIDTY se destaca como principal problema el rentismo. Reportan que, en ciclos recientes, cerca del $50 \%$ de la superficie sembrada (7,000 has.) había sido arrendada a productores del valle (citado por Valencia y Wong 1995:38). Para el ciclo otoño - invierno 1994 señalan el $70 \%$ como superficie agrícola rentada y para el primavera - verano, el $95 \%$ de la superficie total. "El rentista paga la renta y se responsabiliza de todas las labores y se lleva la cosecha; el dueño de la parcela tramita el permiso del agua sin percibir ningún crédito ni ganancia adicional."

Las autoridades tradicionales tienen derecho a retirarle el usufructo de un terreno a quien ellas dictaminen. En virtud de que no hay propiedad privada, los terrenos, que van desde las 4 hasta las 100 has., son entregados por las autoridades para usufructo del solicitante, pero pueden ser retiradas y entregadas a otra persona. 
A esta situación de rezago agrícola se suma el hecho de que actualmente tienen invadidas 60,000 has., de las cuales el $95 \%$ es de agostadero y el $5 \%$ de uso agricola. Los almacenes de ANDSA están en liquidación y la cooperativa MAZOCOBA está embargada. A pesar de que la actividad agrícola sigue siendo la rama productiva más importante, no satisface íntegramente las necesidades de las familias.

Los resultados de la investigación mencionada, mostraron que los ingresos de las familias yaquis son insuficientes para cubrir satisfactoriamente los costos de la canasta normativa de alimentos. Las mayores concentraciones del gasto tuvieron lugar dentro del nivel de la llamada "línea de pobreza extrema" en una proporción muy cercana al 70\% de las familias. El $21 \%$ se localizó en el rango de "línea de pobreza moderada" y sólo el $9 \%$ obtuvo ingresos que permiten acceder a un gasto más diversificado.

El estudio del Centro de Investigación en Alimentación y Desarrollo (1995) demuestra que la disponibilidad potencial de los requerimientos de energía y proteína, es decir, existencia de una oferta alimentaria, no es condición suficiente para la seguridad alimentaria de una población. En promedio, los precios registrados para las comunidades yaquis resultaron ser superiores, con excepción de un solo producto, la leche, a los de los centros urbanos aledaños. En ese sentido, la explicación de los problemas de desnutrición habría que buscarla a partir de las posibilidades reales de acceso a alimentos por familia así como por las condiciones prevalecientes en el entorno ambiental que inciden sobre la situación nutricia de las mismas, tales como la infraestructura y servicios básicos y de salud (Valencia y Wong 1995:49).

El patrón de consumo es relativamente poco diversificado y no se incluyen en la dieta productos importantes como son la carne, las frutas y las verduras, por lo que existen serios problemas de deficiencia de vitamina A. Por otra parte, a diferencia de las dietas indígenas y rurales de otras partes del país, el suficiente abasto de trigo y frijol proporciona seguridad alimentaria y es congruente con la relativamente baja desnutrición proteico energética observada.

Si bien las transacciones monetarias constituyen el medio de acceso más importante a la oferta de bienes alimenticios, prueba de su condición de 
extrema pobreza han desarrollado un buen número de medios alternativos de obtención de alimentos, tales como la recolección, la pepena, el autoconsumo $\mathrm{y}$ formas de abastecimiento menores como la pesca marginal, de mar, canal o laguna, así como el regalo intrafamiliar, la donación de despensas del DIF y PRONASOL, de pollos de las granjas vecinas, bolo en las fiestas, rezaga, huerto familiar, el pillaje y la visita al compadre.

Una de las conclusiones más generales parece dirigirse hacia el hecho de que los altos grados de integración al mercado y la adopción de prácticas productivas asociadas a la "revolución verde" parecen haber causado impactos negativos sobre las formas tradicionales de acceso a alimentos de la Tribu (Valencia y Wong 1995:138)

Cotidianamente, además de la lucha por la tierra descrita en los capítulos previos, la lucha es por el agua. Desde que en 1935 se formó la Comisión de Irrigación de El Yaqui que limpió el canal Marcos Carrillo que llevó agua a pequeñas fracciones de tierra número, el proceso de lucha por el líquido no ha cesado. Incluso la carretera internacional que cruza el territorio yaqui de este a noroeste, desde su construcción en la década de los cincuenta, ha traído aparejados nuevos conflictos ya que, irónicamente, para no pagar peaje en su propio territorio, los yaquis deben certificar su identidad cada vez que pasan. Al mismo tiempo, han tenido que luchar para que, por lo menos, los dividendos de una de las gasolineras que da servicio en su tierra, sean manejados en su beneficio.

La segunda rama de actividad económica es la ganadera, a partir de tres modalidades: la sociedad cooperativa, la familiar o de particulares yaquis y particulares arrendadores. En 1992 se registró la cantidad de 18, 693 bovinos y 15,074 caprinos, en una superficie de 75,000 has.

La pesca se realiza en un litoral de aproximadamente $60 \mathrm{Km}$ de extensión pero carente de una infraestructura pesquera adecuada. El principal producto es el camarón, actividad organizada por la Sociedad Cooperativa de Producción Pesquera de Ribera "Comunidades Yaquis", S.C.L. Exportan su producto a través de la filial de Productos Pesqueros Mexicanos "Ocean Garden Products Inc.". La pesca de escama y molusco se efectúa individualmente. 
Existe además, en el Bacatete, una mina de carbón explotada a través de una cooperativa, sin embargo ésta constituye una extracción mínima de los recursos del subsuelo de la sierra, ya que no cuentan con recursos técnicos que les permitan sacar provecho de estas riquezas. Recientemente se ha instalado una chapopotera, explotada por un "particular" quien a cambio de una cantidad mensual hace uso de la concesión. En las costas yaquis aún se trabajan las grandes salinas que están sujetas a explotación desde los tiempos de los jesuitas. En cuanto a la explotación forestal, existen aproximadamente 21,000 has. de monte alto y en 1993 se obtuvo una producción de más de $25,000 \mathrm{~kg}$. de miel.

Más del $40 \%$ tiene que recurrir a oficios complementarios y la mayoría se emplea de manera eventual, por lo que la migración temporal hacia Guaymas, San Carlos, Empalme y Ciudad Obregón es una opción para desempeñar oficios relacionados con la pesca, agricultura y la construcción. Otros se emplean en las industrias maquiladoras en Hermosillo, Nogales, Navojoa, Tijuana y Mexicali. 


\section{SÍMBOLOS DE LA IDENTIDAD}

En este apartado presento un acercamiento a los procesos de identificación y autoidentificación de los yaquis. En las páginas precedentes, intenté delinear el proceso de su construcción histórica como etnia, a partir de su signo metonímico- definitorio, la tierra. Mi perspectiva aquí, intenta alejarse de una definición inmanente y absoluta de la identidad, para alcanzar, con base en un punto de vista relacional y multireferenciado, el punto de equilibrio en el que confluyen las distintas relaciones - metafóricas - que constituyen la etnoantropología de los yoremes.

Cómo se definen a sí mismos, ser yoreme; cómo lo hacen en su relación con los otros, ser yaqui; y cómo los han visto los yoris, ser cahíta; constituye en principio, una nomenclatura, una clasificación que proporciona las bases para su autoidentificación. Mi planteamiento es que el nombre de la etnia no es sólo significante, puedo afirmar que, como significado, el empleo de determinado signo responde igualmente a determinados momentos relativos al proceso de reconocimiento y autoreconocimiento del grupo.

Así, la literatura etnográfica reconoce a este grupo como yaqui, desde que en 1645 Fray Andrés Pérez de Ribas escribió que la gente le decía: "¿No ves que soy yaqui?" $\mathrm{Y}$ explica "y decíanlo porque esa palabra y nombre significa el que habla a gritos" (Pérez de Ribas 1944:65). No obstante ellos mismos se identifican y se nombran como yoremes. El término yoreme significa propiamente persona, hombre, y también se aplica a los mayos y en determinadas ocasiones a otros grupos indígenas.

Yaqui y yoreme no son sinónimos puesto que, mientras el primero hace referencia a una categoría política - jurídica, el segundo es un etnómino. Yoreme es el nombre que se recuerda cuando en 1533 se encontraron con las tropas de Diego de Guzmán. Ellos eran los yoremes (personas), los españoles los yoris (blancos). De qué manera los yoremes se convirtieron en yaquis no queda muy claro, pero ciertamente tal apelación fue producto de los primeros contactos entre europeos y nativos y corresponde al proceso de categorización anteriormente descrito (Primer momento 1525-1767). 
Contemporáneamente, Evers expone la teoría etimológica sobre la palabra yaqui formulada por el poeta yoreme Ambrosio Castro:

"...el nombre yaqui se originó cuando los españoles, después de haber sometido a los vecinos de los yaquis - los mayos, los ópatas, los pápagos, $\mathrm{y}$ otros- volvieron a intentar vencer a los yaquis. Cuando de nuevo fallaron, los españoles decidieron que era hora de volverse amigos. De esta manera pudieron entrar en el territorio yaqui. Y así sucedió que un día un yaqui iba caminando por el desierto cerca de Tórim, comiendo el fruto de una cactácea, cuando de repente apareció un español. El español comenzó a hacerle preguntas al yaqui ¿Cómo te llamas? ¿Quién eres? El yaqui no entendió al español pero pensando que el español le preguntaba ¿Qué estas comiendo? El yaqui respondió aakim. $A k i$ es el nombre de la cactácea y su fruto, akim la forma plural. (...) Entonces el español sacó papel y lápiz, diciendo: $\mathrm{Ah}$, ah, te llamas yaqui y escribió las letras y-a-q-u-i. (Evers 1987:43, traducción mía)

Esta historia refleja también la manera en que los yoremes ironizan sus relaciones equívocas con los yoris, pues no son raras las bromas en torno a los malentendidos de lenguaje entre yoremes y yoris. Jean B. Johnson reproduce un relato que tiene como objeto la homofonía del término yaqui para dulce: kaka y el chiste en el que un soldado mexicano, al oír el grito "mea, mea" ("muerte, muerte" en yaqui) suplica "mátenme, pero por favor no me meen" (Johnson 1962).

Los misioneros europeos, al oír las semejanzas entre el idioma yaqui y el de los pueblos vecinos del Noroeste de México - mayos, tehuecos, zuaques y sinaloas- eligieron el término nativo cahita para describir ese lenguaje común. Lingüistas y antropólogos emplean hoy día ese término: el yaqui pertenece al sub - grupo cahíta, grupo taracahita de la rama sonorense de la familia utoazteca. El sistema lingüístico cahíta comprende el tehueco, el zuaque, el sinaloa, el mayo y el yaqui. Los tres primeros están extintos, el yaqui y mayo actuales son mutuamente inteligibles y entre ellos existen notables semejanzas en la gramática y el vocabulario. El vocablo cahita significa en español "nada, no hay", y se ha utilizado a partir del siglo XVIII para dar cuenta de la realidad social y cultural entre yaquis y mayos, quienes no requieren de la lengua nacional para comunicarse, lo que constituye un caso único en el noroeste del país. Sin embargo, para los propios hablantes, el 
término cahita como designativo de su idioma y de ellos mismos, no tiene referencia social o étnica alguna; simplemente significa que para ellos, los estudiosos del cahíta, los toman por nada.

Sin embargo, el uso del vocablo cahíta dentro de los estudios lingüísticos ya es ampliamente aceptado y sí tiene una referencia efectiva para los académicos: pertenece al grupo lingüístico utoazteca que abarca, en la República Mexicana, el tarahumar, el guarijío, el pima, el tepehuán, el huichol, el cora y el nahua. A pesar del total bilingüismo, el idioma conocido como cahíta es hablado como lengua materna en los ocho pueblos, rancherías y poblados de la sierra y la costa del territorio yaqui. Presenta numerosos préstamos del español y del náhuatl y se habla corrientemente al seno de la familia, el trabajo, en situaciones rituales y políticas.

Otros autores afirman que el término 'yaqui' era empleado por los nativos para designar al río de mayor tamaño que atravesaba su tierra, y entonces llamaron así a su gente. No obstante que la palabra yaqui ha sido preferentemente empleada por los blancos hacia los yoremes, también estos últimos la han retomado como propia y la aplican a sí mismos en determinadas ocasiones, pero prefiriendo el término yoreme cuando se trata de reafirmar su diferencia.

Para ellos mismos resulta más fácil identificarse como yoremes. Un yoreme lo es por nacimiento, por ocupar una posición en un sistema de parentesco, pero un yaqui adquiere ese estatus por residencia y por un acuerdo jurídico-político a través del cual contraerá derechos y obligaciones con respecto al resto de la comunidad desde el punto de vista económico, político y jurídico. De ahí que pueda decirse que todos los yaquis son yoremes pero no todos los yoremes son yaquis.

"Dice la leyenda que dos venadillos se encontraban en la sierra y por primera vez vieron a un hombre, armado con arco y flechas, y lo llamaron yebuku yoleme... Y ese hombre, comprendiendo el lenguaje del venado, supo que lo llamaron yebuku yoleme. Así como ahora la gente se llama de la misma manera. Yoreme es una persona. (Painter 1986:301, traducción mía)"

Actualmente los yaquis se encuentran atados, como ya se mencionó, a un sistema de agricultura comercial dominado por agentes externos que controlan 
- con excepción de la tierra - los factores esenciales de la producción y distribución; sin embargo, desde el punto de vista cultural, los yaquis son reconocidos, sin excepción, como inflexiblemente persistentes: su complejo calendario ritual devora grandes cantidades de energía, tiempo y dinero. "Los yaquis son tan políticamente autónomos como económicamente dependientes" (McGuire 1986:2). Y esta autonomía, aunque no siempre eficaz, los convierte en un auténtico grupo étnico con una existencia corporada, y no sólo en una población étnica.

Los derechos que se adquieren a través de la membresía a la tribu yaqui consisten en el acceso a la tierra de cultivo, a construir un hogar en la zona y hacer uso de los recursos naturales. También incluye el derecho a participar en las cooperativas pesquera y ganadera, así como en las sociedades de crédito agrícola.

El proceso de identificación étnica de cada individuo yaqui está basado en un criterio de adscripción, no únicamente en su actuación o desempeño, si bien la participación ritual la confirma. Con raras excepciones, la pertenencia individual al grupo no está fundada en una relación genealógica. Los niños se adscriben a 'la tribu' por ser hijos consanguíneos o adoptados de padres yaquis y este estatus se gana a través del lenguaje del parentesco. La genealogía sirve pues, como el atributo pivote en la definición del estatus étnico, así como el elemento principal en la asignación de los derechos y los deberes correspondientes.

El criterio parental a veces se entrelaza con el criterio de residencia, permitiendo una flexibilidad en la que, si un sujeto carece de un progenitor yaqui, pero ha vivido la mayor parte de su vida en un pueblo yaqui y ha sido socializado entre parientes yaquis, es incuestionablemente yaqui. Tal como lo muestra la siguiente genealogía: 


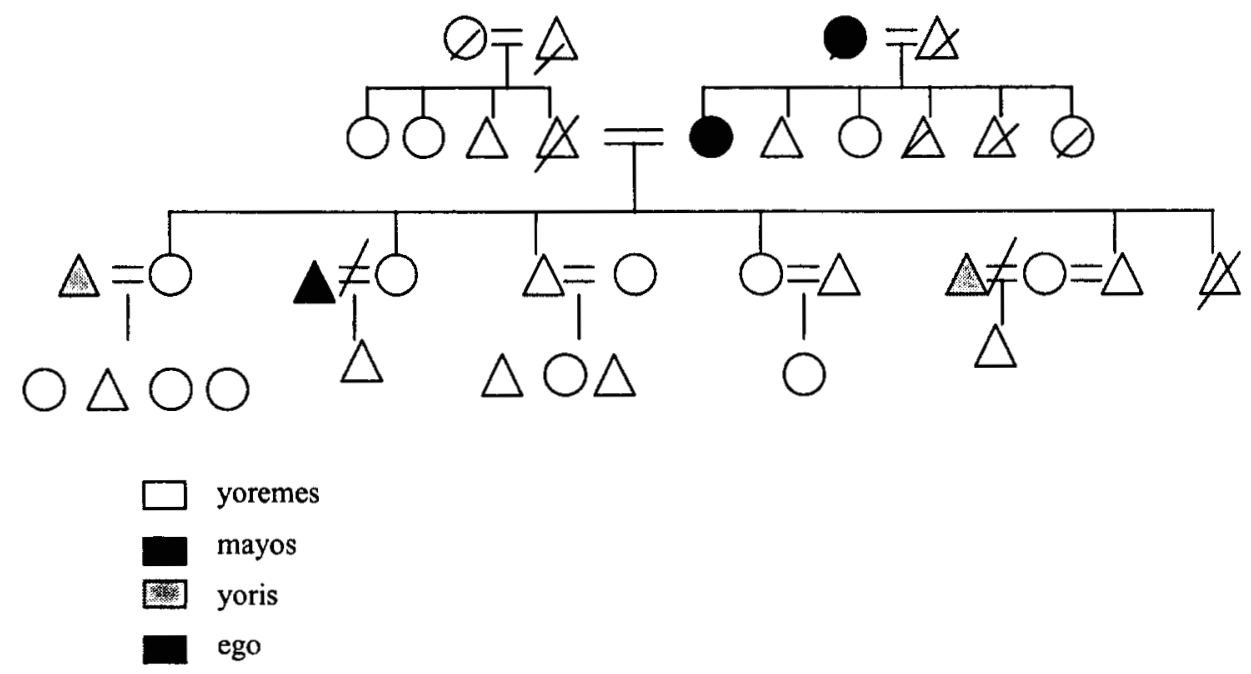

Otro conjunto de atributos secundarios, que no se pueden tomar por el núcleo de la identidad yaqui, son la lengua, el vestido, la participación en organizaciones rituales y políticas distintivas y el haber compartido determinadas experiencias históricas. La categoría parental sería así, el nivel de inclusión más amplio que asegura que un individuo -a partir de la referencia genealógica- pertenece o no a un grupo determinado. Su papel es importante porque determina los derechos y obligaciones de cada uno, al igual que sus relaciones sociales. La regla social colectiva se encarna en el individuo y le confiere su identidad al asignarle un lugar, un nombre y un papel que debe ser suyo debido a su situación genealógica: nace o no como yoreme, adquiere o no la pertenencia a "la Tribu". La identidad individual yaqui no existe sin el referente social y genealógico, el término yoreme sintetiza una multiplicidad de relaciones en un solo lugar.

En suma, es fácil ser un yaqui y cumplir con los derechos y deberes de ese estatus, pero al mismo tiempo, a falta del criterio parental, es virtualmente imposible volverse yaqui. El estatus yaqui puede hacerse válido a través de la participación ritual, pero tal participación no vuelve yaquis a los no yaquis. Y es por esta razón que los yaquis se definen a sí mismos en relación con su propio grupo en términos genealógicos; en relación con el exterior, es la 
sociedad mestiza quien ha tratado continuamente de definirlos, pero ellos no reclaman para sí estas denominaciones.

El cómo se ven a sí mismos queda sintetizado en la siguiente viñeta del Consejo Tribal de Pascua:

"Los yaquis somos notables en tres aspectos: 1) somos el último grupo indígena de América considerado por los blancos como una amenaza importante desde el punto de vista militar; 2) somos uno de los grupos indígenas americanos más ampliamente diseminados terrritorialmente hablando; y 3) hemos sido capaces de conservar nuestra especificidad étnica tanto en México como en los Estados Unidos". (Valencia y Molina en Schechner, s.f., p. 7, traducción mía)

En este contexto, la identidad no es un "problema" para ellos, Ésta se resuelve a través de un elemento preeminentemente clasificatorio: los individuos aparecen como miembros de un grupo. $\mathrm{Y}$ en este sentido el grupo que se presenta como el "otro" inmediato, son los pobladores mexicanos de la zonas aledañas con quienes cotidianamente se enfrentan en sus relaciones jurídico políticas, económicas y sociales. El término que los designa es el de vecinos, los vecinos son aquellos contiguos a los yaquis y cuya cercanía entraña la presencia más sentida y por lo mismo, más cargada de emotividad y prejuicio. No es gratuito que entre los insultos más fuertes que un yoreme puede lanzar a otro es yori sankora, blanco ebrio; sólo equiparables a la ofensa dirigida a la persona misma, al hacer alusión a su descuido en el arreglo personal o al gesto de arrojar el sombrero del ofendido por tierra, en todos los casos la única respuesta posible son los golpes.

Es más fácil ser aceptado como guacho o como de la otra república, es decir, mexicano no sonorense, que como vecino. $\mathrm{Y}$ lo mismo sucede en sentido inverso, se dice que a los sonorenses no indígenas, cuando se encuentran fuera de la entidad, les gusta ser identificados como yaquis, debido sobre todo al estereotipo bravío e indomable con que se les representa. Pero otra cosa ocurre al interior del estado, donde el contacto interétnico es efectivo y si no continuo, por lo menos intermitente, prueba de ello es que uno de los insultos de la población mestiza es "pareces india yaqui". 
Podría argumentarse que la imagen de los yaquis en los centros urbanos aledaños es positiva, desde el momento en que el icono del danzante de venado ocupa gran número de marquesinas, muros y anuncios comerciales de Ciudad Obregón, y que la figura pétrea de los líderes militares Cajeme y Tetabiate corona los extremos norte y sur de dicha localidad; no obstante, tales símbolos son tan sólo imágenes fantasmales de una realidad perdida. Esos yaquis son los "indios muertos" que el imaginario nacional acostumbra glorificar.

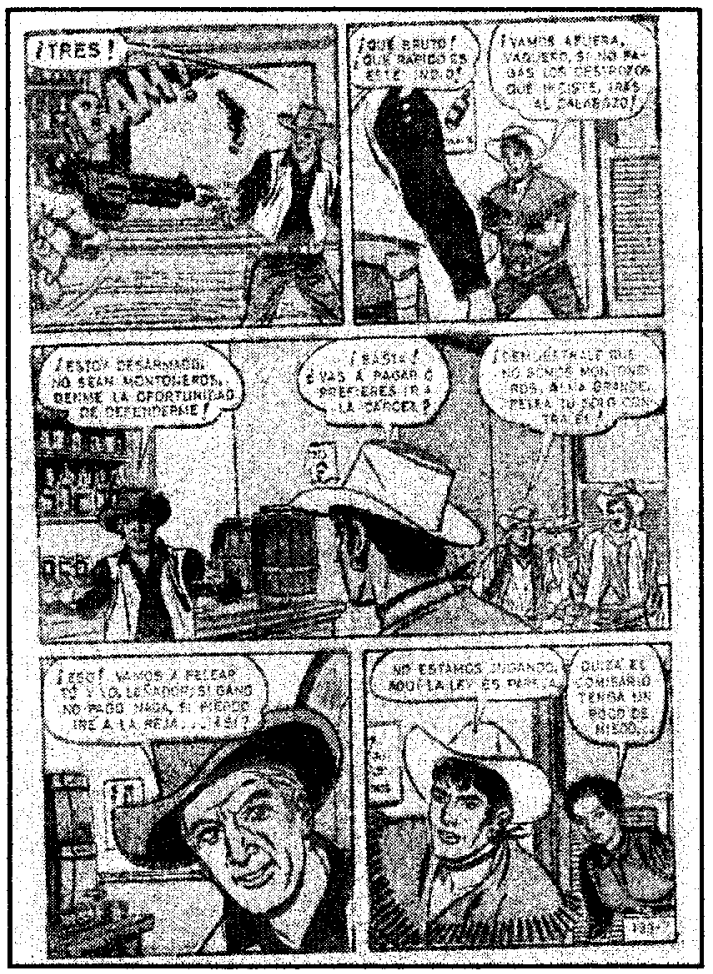

En este sentido, los yaquis ocupan un lugar privilegiado entre las fantasías que la sociedad mestiza fabrica en torno a los héroes indígenas. Desde 1926, diez años antes de la firma del acuerdo de paz entre yaquis y mexicanos, la industria filmica nacional ya estaba dispuesta a invertir fondos en la producción dirigida y protagonizada por Guillermo Calles "El indio yaqui", inaugurando con ella el estereotipo del

indio estoico, áspero, pero con buenos sentimientos.

Filmes posteriores no han hecho sino alimentar dicha estampa, y para hacerla más asimilable hacia el público, fue necesario asemejarla lo más posible a la del héroe vaquero, no es casualidad que en los años sesenta recobrara fuerza la figura del romántico rebelde. 
En esa década, la historieta homónima de Angel J. Mora fue llevada al cine tres ocasiones en México e incluso tiene una versión hollywoodense ${ }^{1}$ que narra la historia de un sheriff americano que se une a la revuelta de los yaquis contra sus opresores mexicanos y en la que Raquel Welch interpreta el papel de la heroína indígena ${ }^{2}$.

La otra cara de la moneda corresponde a la impronta del yaqui pacífico, esotérico y sabio derivada en gran medida de la obra de Carlos Castaneda ${ }^{3}$ : la búsqueda de don Juan Matus o de cualquier otro individuo yaqui con características similares, se convirtió por años en motivo de visitas al territorio yaqui por parte de jóvenes estadounidenses y europeos en mayor medida, pero también mexicanos y latinoamericanos. Todavía en 1989, un yoreme de apellido Matus, por lo demás, nombre bastante frecuente en la región, se quejaba con una estudiante de la insistencia con que fue asediado durante años por ese motivo. No obstante, vale la pena aclarar, sin profundizar en el carácter de la obra de Castaneda, lo que este autor mencionó respecto de la filiación étnica de don Juan Matus:

"... it is impossible for me at this point to determine with certainty his cultural provenience, except in a guessing manner. However, the subtitle of my book is "A Yaqui Way of Knowledge". This is another mistake in which I became involved due to my lack of experience in matters of publications. The Editorial Committee of the University of California Press suggested upon accepting my manuscript for publication, that the word Yaqui should be included in the title in order to place the book ethnographically. They had not read the manuscript buy they concluded that I had said that don Juan was a Yaqui, which was true, but L had never meant that don Juan was a product of Yaqui culture..." (Carta de Carlos Castaneda dirigida a R. Gordon Wasson,

1 "Alma Grande. El Yaqui Justiciero" de 1965, "Alma Grande en el desierto" de 1966 y "El Yaqui" de 1968 (Viñas 1992)

2 El título de este film es 100 Rifles y fue dirigida por Tom Gries (Haliwell 1971)

3 Entre sus libros más importantes se encuentran: Las enseñanzas de Don Juan: una forma yaqui de conocimiento, (traducción de Juan Tovar), México, Fondo de Cultura Económica, 1971; Una realidad aparte: nuevas conversaciones con Don Juan (traducción de Juan Tovar), México, Fondo de Cultura Económica, 1974; Viaje a Ixtlán: las lecciones de Don Juan (traducción de Juan Tovar), México, Fondo de Cultura Económica, 1975; Relatos de poder (traducción de Juan Tovar), México, Fondo de Cultura Económica, 1976 
fechada el 6 de septiembre de 1968, publicada en Magical Blend, octubre 1993, subrayado mío)

Así que una cosa es tener un progenitor yaqui y otra, muy distinta, es haber sido criado como miembro de una cultura y considerarse producto de ella. Eso lo saben Don Juan y Castaneda, pero no lo sabe el gran público de este autor y, al parecer, tampoco los autores de la entrada "Yaquis" de la Enciclopedia de México quienes tomaron literalmente la sugerencia de los editores de la Universidad de California:

"Investigaciones recientes (Castaneda 1971 a 1974) han revelado que para ellos (los yaquis) el conocimiento consiste en obtener con claridad la totalidad de expresiones de la naturaleza y de uno mismo, para llegar a descifrar, en el estadio más alto del saber, lo que cada fuerza natural y personal significa, distinguiendo entre las que son aliadas y las que son enemigas de la existencia. Quien acumula el mayor conocimiento es el chamán: a ello se debe que pueda ayudar a los demás, aun para mantener la salud fisica" (tomo XIV, pág. 8127).

De manera que, cualquiera que desee saber acerca de esta etnia y consulte esta fuente bibliográfica ve en ella la confirmación de una impostura que ya hace tiempo quedó desmontada, pero que persiste, involuntariamente, como una más de las representaciones interétnicas cuyo ámbito intento describir (Leach 1996: 563-566).

Pero no sólo es desde el exterior que se percibe su fuerza, a veces caricaturizada como ya se vio, también en su reconocimiento como yoremes subyace una relación muy importante: la que establecen con los otros grupos indígenas. En este sentido, los yaquis se colocan en una posición, si no de superioridad, al menos de distancia ${ }^{4}$. Basta recordar que varios mitos aluden a un pasado en el que todos los indios estaban hermanados:

4 Debo mencionar que en algunos casos ésta adquiere tintes etnocentristas mas marcados. Ilustro el caso con el relato de un funcionario indigenista en el sentido que algunos yoremes se habían negado a ser atendidos por una médica del Centro Coordinador Indigenista entonces vigente, ya que en su opinión "parecía oaxaquita" (testimonio recopilado en 1989 en Vícam Estación). 
"El yaqui reinaba sobre sus hermanos de las naciones apache, euleve, mayo, ópata, pápago, pima y seri" (Fabila 1978, subrayado mío). "Todos los indios, fueron creados por ella, por Yomumuli" (Giddings 1959, traducción mía).

La especificidad de los yaquis es instaurada así, a partir de la conquista. Es decir, en el tiempo mítico, los otros pueblos indigenas eran como sus hermanos (menores), puesto que proceden de la misma madre Yomumuli, y al parecer ese sigue siendo el caso, pues al referirse a sus vecinos los mayos siempre lo hacen con el diminutivo:

"Yo pienso que si los yaquis nos dejamos quitar la tierra vamos a estar como los mayitos, que ya no tienen nada, están peor que nosotros" (entrevista con don Luis López, rancho Aguacaliente 1988).

La situación marginal de los mayos concuerda con el significado del gentilicio, los mayos son "los de la orilla o rivera" (de mayo' a, orilla, en Lionnet 1977:30).

Pero no sólo en el pensamiento mítico los yaquis aparecen como protectores de otras etnias, su persistencia y cumplimiento en el ritual, por ejemplo, ha llevado a algunos danzantes de pascola y venado yaquis a convertirse en una especie de participantes rituales profesionales, cuando esta actividad les es requerida en fiestas de otros grupos indígenas sonorenses que ya no cuentan con este recurso simbólico, tales como los o'odham (Aguilar Zéleny 1998). O bien su etnómino se convierte en emblema de lucha en el proceso de definición de las fronteras simbólicas al otorgar "en concesión" el término yoreme. En un estudio sobre el proceso de conformación de las identidades étnicas, William Merrill ${ }^{5}$ describe cómo se pasó de la identificación de los pobladores originales de las barrancas chihuahuenses como tarahumaras a su autodenominación como rarámuri. Una vez que este último término fue masivamente adoptado y asimilado por la sociedad mayor, fue necesario redefinir desde el interior del grupo las nuevas fronteras y optar por una estrategia definitoria alternativa. Ésta ha consistido, en la actualidad, en el uso por parte de líderes y representantes indígenas de las barrancas chihuahuenses, del término yaqui yoreme. 
De manera que, si el ejemplo tarahumara - rarámuri - yoreme es interesante, lo es en el sentido que confirma una pertenencia común, la co-referencia mítica que los unifica frente al otro. Pero esta unión (indeferenciación) sólo existe en el mito: si antes de la llegada de los blancos todos los indios eran hermanos, lo eran en tanto yoremes; en cuanto los blancos hacen acto de presencia, surgen entonces los yaquis, los mayos, los eudeves...

Así, se completa el periplo y se retorna al problema de la autodefinición: cuando el observador se coloca desde la perspectiva etnocéntrica (en el sentido amplio) su mirada se dirige hacia el etnómino yoreme; al término yaqui si lo que se enfoca es la relación; o bien, se vuelve la cabeza hacia la nada, cahita, cuando la mirada es unilateral y etnocéntrica (en el sentido restringido).

En efecto, las tres expresiones coexisten como símbolos de relaciones sociales que se constituyen como objeto de continua definición, no sólo en el nivel del lenguaje sino también en el de los tiempos y los espacios. 


\section{UNA FRONTERA VIVIENTE}

La vida cotidiana en las comunidades yaquis tiene un ritmo semanal. Los domingos es el día de la comunila, las autoridades civiles, los cobanaos de los ocho pueblos, dan audiencia y dedican ese día a resolver problemas, demandas o solicitudes de los residentes, ya sean yoremes o "vecinos". No siempre el gobernador está dispuesto a recibir a cualquiera, cuando mucho se logra hablar con su secretario y para lograr comunicación con la más alta jerarquía hay que terer paciencia (a menudo estar dispuesto a hacer acto de presencia dos o tres domingos seguidos). Esperar bajo el rayo del sol de mediodía hasta que el tampaleo inicia los llamados y se hace la ceremonia en que las varas de mando se reúnen en el montículo, es la condición para ser escuchado. El planteamiento de un problema de mayor magnitud que requiera de la decisión de uno o los dos cobanaos de los dos pueblos más importantes -Vícam y Pótam - puede tomar un lapso de tiempo indefinido. La urgencia no es una característica de la vida yaqui. Según uno de mis informantes, ex cobanao de Loma de Guamúchil, los yoremes tienen el compromiso de reunirse dos veces al año con el presidente de la República. No tiene caso reunirse con el gobernador estatal, a quien consideran responsable de desvío de fondos federales destinados en principio a sus comunidades; al menos en 1996, ellos manifestaron su necesidad de tener una reunión con el ejecutivo y expresaron la falta de recursos para cubrir los gastos del viaje. Esperaron el autobús que fue enviado por ellos y después de los dos días de viaje por carretera, llegaron a Los Pinos con un día de retraso a la cita convenida. "La cita era un jueves, pero llegamos hasta el viernes" expresando así su desilusión por no haber sido recibidos, "si sólo llegamos un día después".

Esta anécdota refleja la incomunicación que reina con las autoridades gubernamentales y refleja también un momento en que al interior de las comunidades yaquis no se cuestiona la eficacia de las formas de gobierno tradicional, sino la actitud que "los jefes" deben tener en su relación hacia el exterior. Identifico, sin que el objeto primario de mi investigación sea éste, al menos tres posturas: la línea más tradicionalista y mayoritaria representada por el gobierno de Vícam Pueblo, la disidente focalizada en los pobladores de Vícam Estación "del otro lado de las vías" que en los años ochenta se conocía como "los Ripaldos", y la que denomino aquí como "modernizadora", que 
aboga por una relación menos rígida con la sociedad circundante mantenida por jóvenes profesionistas de los pueblos sureños. Su asociación con partidos políticos no es automática, aunque el PRD tiene un cuerpo de asesores técnicos -agrónomos, economistas y administradores - conformado por la primera generación de yaquis que ha tenido acceso a la educación universitaria y el PRI auspició en 1990 los uniformes del equipo de béisbol.

Por lo menos dos de los ocho pueblos se encuentran en un proceso de continua definición, tanto por su origen, como por constituir la frontera viviente frente al amenazante crecimiento del núcleo urbano mestizo constituido por Ciudad Obregón. La Loma de Guamúchil y la Loma de Bácum fueron fundadas a raiz de la pérdida de los pueblos tradicionales de Cócorit y Bácum respectivamente, con la intención de restituir a ocho el número de pueblos. Así, la elección de la población yoreme y de las autoridades tradicionales de Cócorit de no "vivir con los yoris", llevó a sus habitantes a fundar la Loma en el extremo sur del territorio yaqui, a $16 \mathrm{Km}$ de Ciudad Obregón y sobre la carretera internacional. Esta particularidad se refleja en el ritmo acelerado de cambios que se cristalizan en los últimos siete años. Esta comunidad de 494 mujeres y 469 hombres (Valencia y Wong 1995:21) cuenta con Telesecundaria, un puente peatonal sobre la carretera de cuatro carriles, tanque elevado, servicio de caseta telefónica a ambos lados de la carretera, centro de salud y un pronunciado crecimiento habitacional hacia el lado este de la carretera. Pero no tiene calles pavimentadas, agua potable, ni drenaje. Si se tomara la vestimenta femenina como distintivo de asimilación, seguramente la Loma ocupaba el sitio de honor, ya que a diferencia de las mujeres de los pueblos más septentrionales que visten faldilla, refajo y rebozo, muchas de las jóvenes de esta comunidad usan pantalones, mallas ajustadas y botas de minero. Las alianzas matrimoniales entre yoris y yaquis son cada vez más comunes así como la pérdida de la lengua materna entre las generaciones más jóvenes.

Así, frente a las otras comunidades yaquis, la Loma se presenta como una de las más amestizadas pero, al mismo tiempo, la que sirve de "muro de contención" del avance yori. A pesar de que muchos de sus habitantes tienen distintos oficios, en la construcción, la docencia, ganadería y pesca, la actividad fundamental sigue siendo la agricultura. 
Desde luego que no se trata de la agricultura de subsistencia sino de aquélla supeditada a las instituciones de crédito oficiales, que los ha convertido en agentes pasivos de fuerzas económicas externas ${ }^{1}$. La actividad directa en los predios agrícolas, la negociación de los créditos, la compra de insumos y la colocación en el mercado de sus cosechas, son las ocupaciones que consumen la mayor parte del tiempo de los varones yaquis. Estacionalmente, su fuerza de trabajo es requerida en la zafra del camarón, por lo que migran cortas distancias a los poblados costeños ${ }^{2}$. El corte de madera -mezquite y carrizo- es una actividad relativamente importante para cuya ejecución únicamente es necesario contar con la autorización especial de las autoridades tradicionales.

No obstante que el trabajo agrícola es fundamentalmente masculino, las mujeres yaquis colaboran en algunas actividades en los períodos que requieren de mayor participación. Si bien se considera parte de su labor salir a vender nopales o productos marinos y tortillas de harina, cada vez más, las mujeres jóvenes obtienen empleo como trabajadoras domésticas, maestras y promotoras sociales. Los niños pepenan, recolectan, acarrean agua, pastorean chivas, hacen mandados, ayudan en la pesca y cuidan a sus hermanos menores. Como se ve, el trabajo del padre no es el único sostén que garantiza la subsistencia familiar.

La configuración del poblado es muy homogénea, a diferencia de la que prevalecía desde principios de los años setenta descrita por Nolasco (1974) en

${ }^{1}$ Entre 1950-52 se agrupó a los agricultores de subsistencia en sociedades de crédito con aproximadamente 30 miembros cada una. Las parcelas individuales se unieron para formar superficies comunes y fue obligatorio sembrar las superficies irrigadas con dos cultivos comerciales: trigo y algodón.

2 En 1958 se inició la cooperativa con 150 socios de Pótam y Belem que se trasladaron al nuevo pueblo de Las Guásimas. Hoy día los pescadores yaquis están organizados en grupos de trabajo de 15 hombres, con frecuencia emparentados, que dependen del consejo de administración de la cooperativa, formado por miembros elegidos anualmente. La pesca más importante es la de camarón, que se practica desde agosto hasta fines de octubre, y además se obtiene corvina, lisa, pulpo y ostión. El producto diario de la actividad de cada pescador se sitúa entre los 15 y 20 kilos. Los miembros de la cooperativa que no viven en Las Guásimas se instalan en Bahía de Lobos o en la playa de Los Algodones durante el período de pesca. 
los pueblos más grandes como Pótam, en la que señala la existencia de estratos económicos diferenciados, en la Loma las diferencias de ingreso no son significativas. No obstante, salta a la vista y ellos mismos comentan, que los yoremes residentes en Arizona, Estados Unidos, que visitan en ocasiones rituales a su parentela sonorense tienen más recursos; lo cual es motivo de reproche frente a los yoris la falta de reconocimiento a su lealtad, ya que algunos yoremes consideran que estarían en mejores condiciones económicas si habitaran en las reservaciones del "otro lado" o bien, se podrían beneficiar de los subsidios que por su origen étnico el gobierno de Estados Unidos podría proporcionarles. Asimismo, comentan que su lealtad con México no es correspondida, puesto que a menudo rechazan propuestas de empresarios japoneses y estadounidenses, principalmente, para explotar sus recursos marinos y mineros. 
III

LA UNIDAD ESPACIO TEMPORAL DEL CICLO 
Este capítulo está dedicado a la identificación, presentación y análisis de las regularidades significativas de la dimensión territorial y espacial de las comunidades yaquis. Asimismo, me interesa mostrar cómo tales regularidades, al entrar en combinación con los movimientos propios del rito - también regulares y repetitivos- constituyen un texto, que además de mostrar una determinada ocupación del espacio, establece patrones rítmicos particulares a esta cultura. Retomo la noción de ritmo de la obra de LeroiGourhan (1971:307) para quien este principio, junto con los sistemas de formas y valores, es definitorio de un estilo étnico.

El acercamiento al polo espacial está compuesto por la lectura de los marcadores espaciales donde tiene lugar la vida comunitaria - modelada por la actividad ritual- constituidos concéntricamente por el territorio, los ocho pueblos, el pueblo, el tebat o patio, la iglesia, el altar y el hogar; así como las nociones asociadas, siendo la más importante este - oeste (arriba/abajo) seguida de aquélla que distingue el centro de la periferia (adentro/afuera).

Los ritos ubicados en el espacio así conformado - que constituyen en sí mismos el objeto de mi estudio y cuya descripción sintagmática y etnográfica llevo a cabo en el capítulo IV - muestran el paisaje en su dimensión semiótica a partir de una ocupación sincrónica del mismo. Dicha ocupación, que se consuma a través del movimiento de los actores rituales, no es en absoluto continua, se trata por el contrario, como intento mostrar, de un pronunciamiento - en el sentido pragmático- que marca el principio y el fin de cada acontecimiento sagrado. La repetición pautada del movimiento, característica del rito, concierta así, el ritmo singular del texto cultural que nos ocupa.

Tal linealidad del enunciado, basada en los dos principios de mito, la narratividad y la repetición; muestra la temporalidad del proceso cuya expresión ordenada acontece en el marco de un calendario litúrgico que abarca un ciclo ritual anual, en el lapso de un año solar. 
En este sentido, considero que la distinción entre la dimensión espacial y la temporal es puramente técnica y está concebida aquí como una relación bipolar representativa de un principio rítmico particular.

Tal como espero mostrar al cabo de este trabajo, la identificación de los actos rituales (movimientos) en espacios y tiempos existen en calidad de enunciados que pueden ser leídos y situados en un contexto pertinente, que da la base para su interpretación. De manera que, a fin de dar cuenta de este transcurso indivisible, intento seccionarlo con la ilusión de reintegrarlo al cabo de mi argumentación. 


\section{LÍMITES SIMBÓLICOS}

Por ahora, la lectura de la dimensión espacial se desarrolla en un plano horizontal, cuya información - tal como espero mostrar - se encuentra codificada a partir de un conjunto discreto de reglas. Tal como opera el estudio de las orientaciones de sitios arqueológicos, donde la arquitectura y la coordinación de ésta con el ambiente natural constituye un sistema de códigos que se plasma en el paisaje: los edificios aislados, los conjuntos de edificios y planos de asentamiento, su coordinación con puntos del paisaje -cerros, valles o marcadores artificiales- son los signos que conforman un mensaje a partir de su posición relativa en el sistema.

Tradicionalmente el grupo yaqui ocupaba una larga faja costera y de valle al sudeste del actual estado de Sonora, que abarcaba desde la rivera sur del río Yaqui hasta el cerro Tetakawi, al norte de la actual ciudad de Guaymas. Con la sedentarización del grupo bajo el control de las misiones jesuitas, la población se concentró en ocho poblados situados de sudeste a noroeste a lo largo del Valle del Yaqui, los cuales han constituido la base organizativa y territorial del grupo.

En tanto que todo límite, geográfico o no, posee una dimensión simbólica de representación objetal, lo que me interesa identificar aquí es, sobre todo, cuáles son los marcadores que operan como señalizaciones, como fronteras del ya en sí mismo, signo metonímico de la etnia: su territorio tribal (Bourdieu 1984:138).

En este sentido, el conjunto del territorio aparece compuesto por tres zonas diferenciadas, las cuales, a su vez, tienen como soporte características geofisicas particulares: un área serrana - la sierra del Bacatete-, una zona costera que comprende poblados pesqueros como Las Guásimas, Bahía de Lobos y Los Algodones y el Valle, en donde se localizan las tierras irrigadas, los ocho pueblos cabecera y más de cincuenta rancherías. 


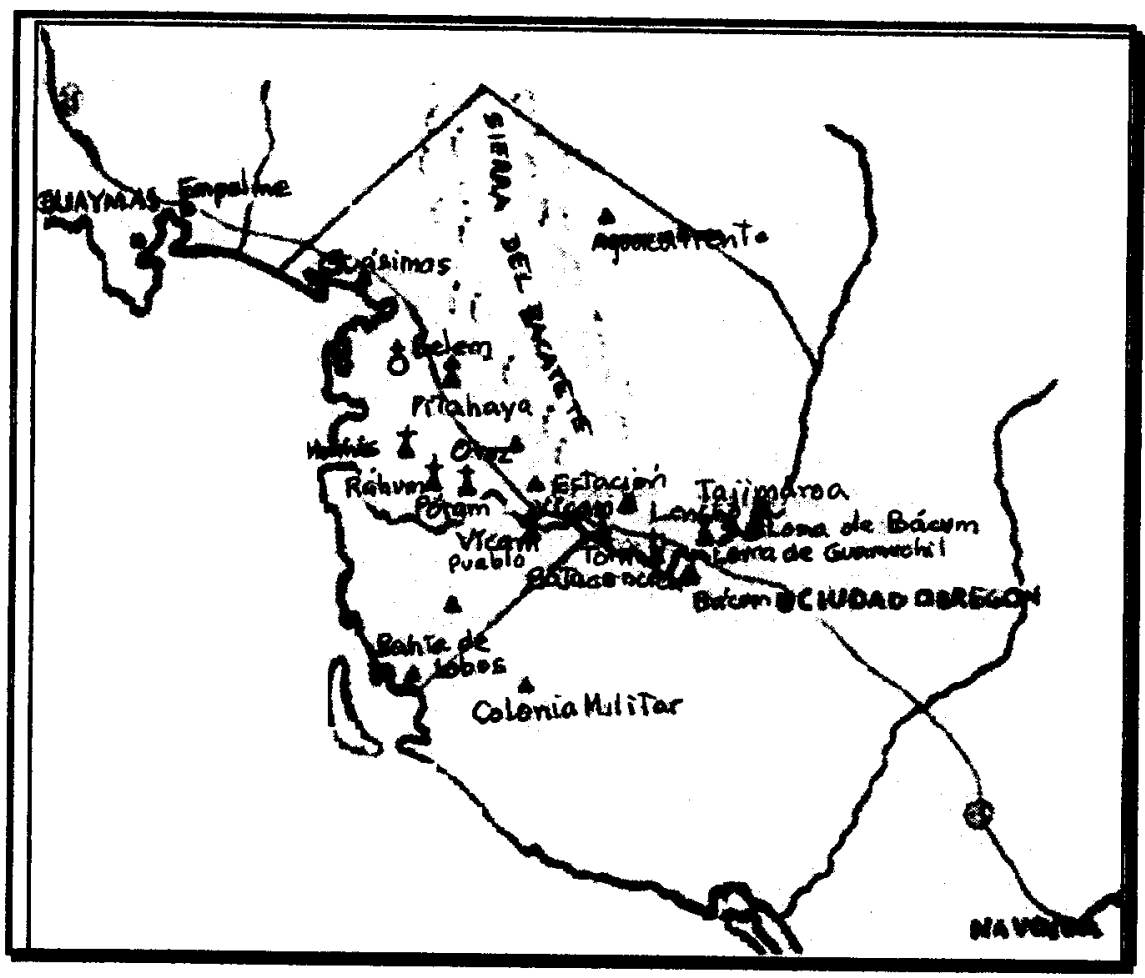


Cada uno de estos marcadores geográficos está rodeado por campos de significados que encontramos en los mitos y en las referencias del lenguaje situacional y vestimentario presente en los rituales. Procedo a describir cada una de las tres zonas diferenciadas para, posteriormente, analizar su relación y en consecuencia, el sentido que de ella se deriva.

La sierra kawi o, como también se le llama en el lenguaje coloquial, júuya, está asociada al concepto más complejo de pocho'oria, el cual se traduce literalmente como el monte. Esta región comprende la sierra del Bacatete, llamada también por los mestizos como sierra del Yaqui o del Pico de Guaymas, que pasó a formar parte del los títulos legales de la tierra por la que lucharon durante siglos, a partir de los decretos presidenciales de 1937.

La sierra del Bacatete, en cuyas laderas se encuentran varios ranchos como el Papalote y Aguacaliente, es la sede de la cooperativa ganadera y delimita la frontera este. Constituye una cadena montañosa aislada y de poca altura $(1,300$ metros de elevación máxima) que corre a lo largo de $64 \mathrm{Km}$ paralelamente al Pacífico, a una distancia de 20 a $30 \mathrm{~km}$. Su etimología refleja en gran medida su carácter: "donde está la gente" e históricamente constituyó el refugio y base de operaciones de los rebeldes yaquis, así como el escenario de algunos de los episodios más cruentos de la guerra. Se cuenta que el mayor Agustín de Vildósola logró organizar la resistencia española y consiguió derrotar tres veces sucesivas a los yaquis en las famosas batallas de Tecoripa, cerro del Tambor y Otancahui. De la magnitud de estos combates da testimonio este último locativo cuya etimología es "cerro de los huesos", por la cantidad de esqueletos que ahí quedaron. Debido a éste y otros testimonios, la sierra constituye el soporte del discurso mítico sobre el territorio y sobre la guerra misma; aún hoy, se identifica como hogar de los yaquis broncos, por oposición a los mansos, habitantes de los pueplum.

Si la porción oriental del territorio, donde comienza la subida a la sierra a un costado de la localidad de Lencho, frente al pueblo cabecera de Loma de Bácum, se diluye en la sierra de Chihuahua, entonces debe entenderse que las fronteras no son líneas de demarcación absoluta, sino que son objeto de continua definición. Al poniente ocurre algo similar, el océano, báawe no es el fin del territorio yaqui, de alguna manera también les pertenece, ya que en él habitan, según los mitos, una parte de aquellos antepasados diminutos de los yaquis, los surem, que no quisieron resignarse al destino de evangelización 
que les pronosticara el árbol parlante, al contrario, huyeron de él y tomaron la forma de ballenas y animales marinos que aún pueblan el Mar de Cortés, otros se convirtieron principalmente en hormigas y en los animalitos del monte: ciempiés, alacrán, lagartija (Olavarría 1989).

El punto que conecta estos dos ámbitos (júuya), es el pueblo de Bácum, por ser, como ya se mencionó, el pueblo cabecera más cercano al camino de terracería que comunica con la sierra y al mismo tiempo, por la laguna que le da su nombre, la conexión con el mundo marino. Bácum, del yaqui bajkom significa literalmente "hasta donde llega el agua" y ahí se encuentra la laguna del mismo nombre, hogar mítico de los héroes culturales yaquis como Bóbok, el sapo. Desde 1937, tanto el pueblo de Bácum como la laguna dejaron de ser tierra yaqui, lo que dio pie a la fundación de Loma de Bácum, sede de la festividad más importante de todo el año, la Virgen del Camino. Desde su fundación en 1617 por los jesuitas, Bácum ha sido considerado un centro sagrado, allí nació Cajeme y ahí fueron asesinados, en la iglesia consagrada a Santa Rosalía, 120 prisioneros que habían ido a solicitar la paz el 18 de febrero de 1868. El edificio de la iglesia fue incendiado con los cadáveres adentro.

Entre la sierra y la costa, el este y el oeste, se sitúan los ocho pueblos tradicionales yaquis. Y si, como veremos más adelante, el este es "de donde todo viene" y el oeste se asocia con la muerte, entonces lo que ocurre entre una cosa y otra es la vida en los pueblos, pueplum.

Los ocho pueblos tradicionales son, de sudeste a noroeste, Loma de Bácum, Loma de Guamúchil, Tórim, Vícam, Pótam, Ráhum, Huirivis y Belem. La población actual no sólo comprende a los habitantes de los ocho pueblos y rancherías aledañas, quienes se adscriben para fines políticos, religiosos y rituales a uno de los ocho pueblos tradicionales. En seis de las localidades habita el $72 \%$ de la población, cuatro de ellas corresponden a pueblos tradicionales.

Hay colonias yaquis en las reservaciones de Guadalupe, Pascua y Scattel en Arizona; en las ciudades sonorenses de Magdalena, Caborca, Nogales, Hermosillo y Obregón; y en Tijuana y Mexicali en Baja California. Otros viven en Veracruz, Yucatán y Jalisco, siendo los descendientes de los deportados en años anteriores por motivos de guerra y en La Paz, Baja 
California Sur, quedan aún descendientes de aquéllos que fueron enviados a trabajar en las minas. Los propios yaquis estiman que la tribu entera, en ambos lados de la frontera, comprenderá unos 40 mil individuos.

De acuerdo con estimaciones del INI basadas en el XI Censo General de Población y Vivienda, 1990, el mayor número de hablantes de yaqui habitan los municipios de Bácum, Guaymas, Cajeme, Empalme y Hermosillo alcanzando un total en el estado de Sonora de 10,081, frente a 27,410 hablantes de mayo. No obstante, un censo de 1992 (Valencia y Wong 1995:19) llevado a cabo por el Magisterio de la Tribu proporciona el número de 23,719 yoremes agrupados en más de 2,000 familias establecidas en 61 comunidades.

Así, los ocho pueblos mantienen, cada uno, una organización espacial que varía únicamente en función de la densidad de la población y de la proporción de habitantes mestizos avecindados. Los ocho pueblos se ubican del lado oeste respecto de la carretera internacional que hoy día divide longitudinalmente el territorio yaqui, quedando por consiguiente los ocho poblados con los mismos límites: al oeste el mar, al este la carretera y más allá de ella kawi, la sierra; al sur de Loma de Guamúchil y al norte de Huírivis, el circundante universo mestizo.

Al mismo tiempo, para la mayoría de los yaquis, el espacio territorial se representa dividido en dos bloques, al sudeste Tórim, Loma de Guamúchil y Loma de Bácum de alguna manera encabezados por Vícam; al norte Ráhum, Huirivis y Belem por Pótam.

Vícam Pueblo se ha constituido en el centro político del grupo y en el lugar de encuentro de las autoridades tradicionales de los ocho pueblos. Como un ejemplo más en el proceso de lucha por las clasificaciones, los yoremes decidieron desprender la sede de su gobierno tradicional de Vícam Estación hacia Vícam Pueblo (sólo a $5 \mathrm{Km}$ de distancia), en virtud de que desde los años veinte, con el paso de la línea férrea, en esta ultima población habitan más yoris que yaquis. Vícam Estación es el lugar de mercado, el centro administrativo y sede del ejército, la policía, los bancos, servicios sociales, médicos $\mathrm{y}$, en general, es la sede para las comunicaciones: base de la línea de transportes suburbanos, la caseta telefónica y telegráfica, así como un hotel propiedad de una ciudadana estadounidense. Contrasta con la economía de 
recursos de Vícam Pueblo, cuyo tebat contiene únicamente la iglesia con sus cruces y el sencillo recinto de la guardia tradicional.

La expresión gráfica de esta perspectiva permite identificar así, las fronteras del territorio que, en un momento dado, coinciden con las de la etnia. En el continuo proceso de definición del que son objeto, se distinguen dos polos, aquél que se refiere al lindero externo a la etnia, la línea frente a los vecinos, los mexicanos o miembros de la otra república. Se trata de una frontera interétnica que corresponde preferentemente al norte y sur de la región, que como ya se mencionó en el capítulo segundo, ha sido objeto de lucha no sólo en el plano de las clasificaciones - preferentemente expresivo - sino en un proceso efectivo de carácter instrumental, que se transporta al terreno de lo jurídico - político. Lo anterior no implica que el mar y sus recursos, así como los terrenos serranos, no hayan sido objeto de batalla legal y política, por el contrario, el acceso exclusivo a los recursos pesqueros no se obtuvo sino hasta la década de los setenta.

Por su lado, los márgenes internos, los que delimitan al valle frente a la sierra y la costa, el centro frente al este (arriba) y oeste (abajo); son también los que separan a los yoremes de sus antepasados históricos - los broncos de la sierra- y de sus antepasados míticos - los surem-. Estos lindes son igualmente borrosos pero menos negociables, para comunicarse con los pobladores del monte y del país de los surem, es necesario un esfuerzo expresivo, un ritual. Cabe señalar que la extraterritorialidad de los yoremes que viven en Arizona se desvanece exclusivamente en ocasión de las fiestas. 


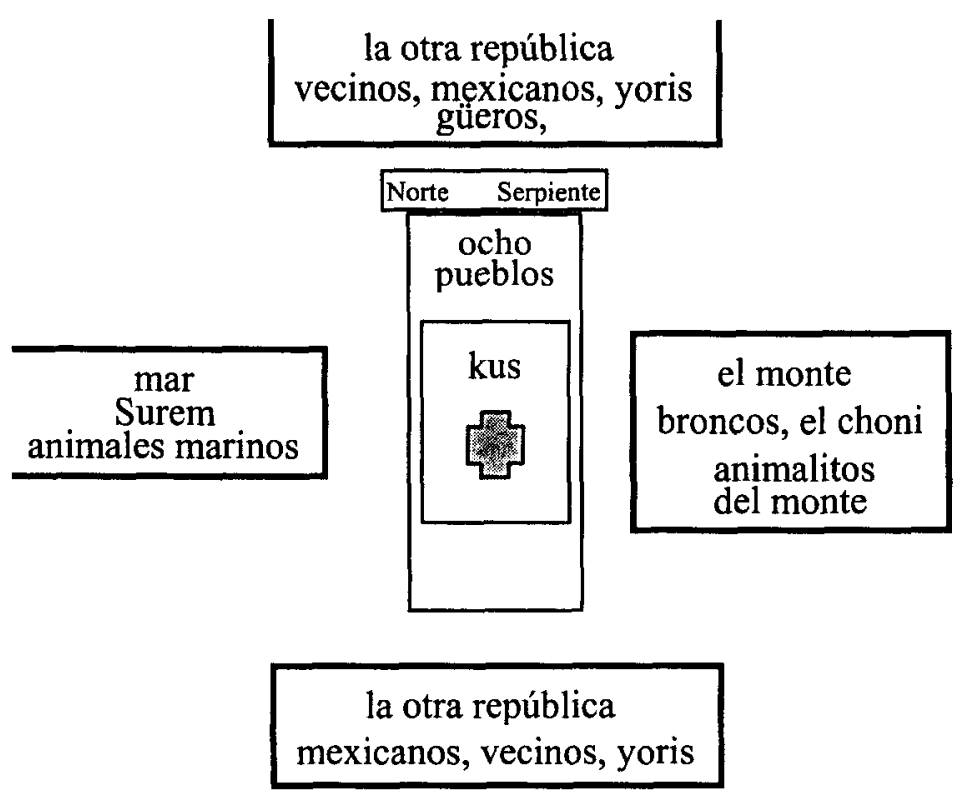

En este ejemplo, los registros arquitectónicos en combinación con los marcadores naturales no sólo tienen relevancia como contexto sincrónico de la vida ritual, igualmente refieren una historia por demás pertinente: la de la sedentarización, urbanización y conversión de la población amerindia de la región a manos de los misioneros jesuitas. A su arribo, los yaquis vivían en rancherías irregularmente distribuidas a lo largo del cauce del Río Yaqui. Tales asentamientos consistían en conjuntos de casas en forma de domo, cubiertas de bajareque. Los misioneros transformaron este patrón al congregar a los nativos alrededor de ocho pueblos. La percepción de Spicer es contundente:

"Cuando los jesuitas con tanto éxito impulsaron la construcción de pueblos, estaban introduciendo no sólo una nueva base material de la vida, sino también los cimientos de una nueva concepción del universo. Huya aniya pasó a ser una parte especializada de un todo mayor, en lugar del todo mismo. Sin embargo, huya aniya no fue reemplazado, 
como sin duda habrían deseado los jesuitas; se convirtió en el otro mundo, el mundo salvaje que circundaba los pueblos. Las casas estaban construidas en ordenamientos más o menos armoniosos en torno a la nueva y única iglesia y sus edificios anexos, como la vivienda y los corrales del misionero. Había mucho menos fusión con el ambiente" (Spicer 1994:77).

En esta perspectiva, la continuidad ordenada e ideal entre la actividad humana y el mundo natural, propia del universo precristiano de los yoremes, adquirió su primer lindero significativo con la instalación del nuevo umbral entre el monte y los pueblos, el huya aniya y los pueplum. Frente al pasado continuo asegurado exclusivamente por el movimiento del cielo, único referente en la determinación de los puntos cardinales, o de cualquiera otra referencia considerada como fija, el pueblo se estableció de inmediato como el nuevo centro del mundo y su asignación fue, en cierto modo, la garantía de rotación del universo alrededor de él. "La propiedad fundamental de las ciudades es dar una imagen ordenada del universo" (Leroi-Gourhan 1971:320).

De acuerdo con los estudios etnohistóricos de Spicer, en el siglo XIX estaba difundida la creencia en la existencia de un documento perdido, pero que en algún momento debía aparecer, que los yaquis presentaron ante los mexicanos que se negaban a reconocer sus límites. Esta leyenda secular, el Canto de la Frontera (Spicer 1994: 216), relatada también en el siglo XX, evolucionó hasta convertirse en mito, sufrió una sacralización estrechamente relacionada con la necesidad de defender la tierra contra las intrusiones de los mexicanos. Según esta nueva mitología del XX, una vez definida la frontera sagrada - hecho que los yaquis ubican mucho antes de la llegada de los españoles - los profetas yaquis volvieron su atención a la fundación de los ocho pueblos: "Estos fueron fundados de este a oeste con los mismos nombres que tenían en el siglo XIX; en cada fundación un profeta yaqui realizó trabajo ceremonial tekipanoa en el sitio del pueblo, designando así el lugar como sagrado" (ibidem).

Según se cuenta, el nombre de cada lugar ya se conocía, pero en varios casos el sitio es comparado con un lugar de referencia bíblica y se indica un patrono o una patrona del pueblo o de la iglesia. Así, para tomarlos en el orden del mito de la Fundación de los Pueblos, Cócorit fue designado por José Ignacio Vailutey; Bácum por un profeta del Canto de la Frontera, Andrés Cusmes, quien nombró patrona a Santa Rosalía e identificó el pueblo con el Edén, 
Tórim por Patricio Huilocolli, quien nombró patrono a San Ignacio; Vícam por Justo Liozo; Pótam por Juan José Sealey; Ráhum por Couguama que nombró patrono a San Manuel; Huírivis por Simon Yomomoli, y Belem por Cosme Ta'ajinkoi, quien nombró patrono a San Pedro (Giddings 1959: 45).

Lo que tenemos aquí es la sanción sagrada de la ubicación de los Ocho Pueblos en un mito, que no sólo choca con los hechos históricos que conocemos, sino que los invierte. La Fundación de los ocho pueblos, igual que el Canto de la Frontera, se ubica antes de la llegada de los misioneros, o de cualquier otro español, y se atribuye en cada caso a un profeta yaqui. La evidencia histórica indica que no había pueblo alguno antes de la llegada de los jesuitas y que todos los que se fundaron, fueron resultado del esfuerzo de los religiosos por persuadir a los yaquis de que concentraran sus viviendas en ocho lugares. Al afirmar que los fundadores fueron yaquis, y que este evento fue anterior a la intervención foránea, el mito indica claramente una tendencia, propia del momento vivido entre los siglos XVIII y XIX, a la intensificación de la conciencia étnica. Es decir, los yaquis rechazan la idea de que los europeos hayan desempeñado un papel en la formación de las instituciones bajo las cuales ya se acostumbraron a vivir.

De manera que los Ocho Pueblos son yaquis no sólo en el presente sino también en sus orígenes: fueron fundados por profetas yaquis y con ello obtuvieron la sanción divina para su creación, exactamente igual que para el territorio tribal. El uso de nombres cristianos para todos los profetas, junto con apellidos yaquis no sugiere contradicción alguna, puesto que se rigen por una lógica propia.

Así, cada formación montañosa recibe su sanción: su nombre y carácter sagrado, a partir del mito. Los sobrenaturales fueron el origen de la delimitación de las fronteras, al atravesar todo el territorio de sureste a noroeste cantando himnos cristianos; algún tiempo después, los profetas yaquis, que se habrian reunido con los sobrenaturales, tuvieron visiones en ocho lugares diferentes: "Uno de ellos vio el jardín del Edén, ordenó fundar Pótam, otro vio a Santa Rosalía, lo que dio origen a Bácum, y fue igual para los ocho pueblos" (Giddings 1959:45)!

1 Este mito "La inundación y los profetas" (Giddings 1959:45-46) forma parte de mi análisis publicado en 1989 . 
Como puede observarse, el recorrido en dirección sur a norte a través del territorio es una de las constantes de estos mitos, y como espero comprobar más adelante, este gesto, que los matachines yaquis repiten cada año en la fiesta de la Virgen del Camino, pero en dirección contraria, constituye en sí mismo un texto, entendido como una multiplicidad de códigos de naturaleza diversa, una especie de proclama dictada en lenguaje situacional, a la vez que un acto efectivo de toma de posesión.

El último relato de esta geografia sagrada es el que Fabila tituló "Leyenda yaqui de las predicciones". En uno de sus registros, en mi estudio antes citado, defino su mensaje como el origen de los propios yaquis y no tan sólo como el origen de las elevaciones y montañas del Bacatete, que como resultado de una lectura superficial se podría suponer. Considero aún válida tal afirmación, pero al mismo tiempo, retomo nuevas perspectivas. La leyenda citada, de cuyas diferentes versiones publicadas me permito presentar un resumen, refiere que:

"En tiempos de los surem el suelo estaba siendo asolado por una enorme serpiente que apareció desde el norte. Los yaquis se prepararon militarmente para atacarla, pero sus flechas no hacían mella en el caparazón escamoso del animal y fueron vencidos. En esta situación, los jefes yaquis, encabezados por uno de nombre Vía Láctea decidieron pedir auxilio al mago Chapulín Guóchimea, designando como mensajera a Golondrina. Mientras los guerreros esperaban a la golondrina, el mago llegó de un solo salto hasta donde se encontraban los generales nombrados como Vía Láctea, Nieve y el Chiquihuite; después de un baño vegetal, se sentó arriba de un árbol a esperar el paso de la serpiente. Al paso del reptil gigante, el saltamontes la decapita con sus espolones hasta que la cabeza, ya desprendida del cuerpo, llega rodando al punto conocido como Boca Abierta, donde habla con el jefe Yazicue: "yo no pude exterminar al yaqui, porque fui vencido por el mago chapulín, mi propósito era reinar entre las tribus de Sonora, pero como me derrotaron, te advierto e invito a que se cuiden mucho, porque pasando los años vendrán del Oriente y del Sur unos hombres blancos que vomitan fuego. Si quieren salir avante en la lucha, quítenles sus propios medios ofensivos y combátanlos sin miedo y descanso; de lo contrario serán esclavizados, despojándolos de su territorio". (Fabila 1978:253) 
El recorrido de la profecía, en dirección norte sur, va marcando los cerros del Bacatete: Yazicue, Omteme, Cúbuae, Corasepe, Akimore, Re'epecame y Guochimea. Este último, que corresponde al cuerpo de la serpiente convertido en cerro lleva, en lo que parecería una contradicción, el nombre de su verdugo, el saltamontes. El detalle con que se narra el recorrido de la profecía, de un punto a otro, recuerda el gesto (ritual) que proclama la propiedad sobre un símbolo. ${ }^{2}$

Este carácter ambiguo de la serpiente está presente en lo más profundo del pensamiento yaqui. A la vez amenazante, puesto que asolaba el territorio, y protectora, puesto que los previene de los blancos, la serpiente gigantesca aparece como centro de un campo de significados que sólo queda de manifiesto a partir del análisis que prosigue, el cual se desenvuelve en los aspectos del ritual, la cosmología y la mitología y que presento en los capítulos que siguen.

2 En efecto, la identidad como recorrido, simultaneidad metafórica y metonímica de categorias culturales que se actualizan en la apropiación espacial, el espacio vivido. 
Una de las constantes que salta a la vista, al mirar el paisaje de los ocho pueblos, es la manera en que cada uno de ellos construye su espacio sagrado con base en un número discreto de elementos. No quiero decir que sean idénticos, tan sólo que la disposición de los componentes más significativos, lo que constituye el centro del poblado, compuesto por un espacio abierto nombrado tebat, presenta regularidades que me permiten considerar como base de mi presentación el análisis de uno de ellos, el de la Loma de Guamúchil.

Dejo de lado, así, las diferencias evidentes entre los poblados en lo que se refiere a la densidad de población y tipos de asentamiento, para centrar mi descripción en los espacios que están sujetos a prohibiciones, los que se constituyen como sagrados. En este sentido, la perspectiva concéntrica parece dominar no sólo en las localidades sonorenses, sino también en las de más reciente fundación en Arizona, Estados Unidos'.

El pueplo se distingue por el 'centro', tebat o patio, delimitado por cuatro cruces. Una de ellas, la central, es la cruz del perdón. En este espacio se sitúan, sin excepción, la iglesia y el cementerio - al oeste- y enramadas que varían en número de acuerdo a la época del año que se trate: por lo menos dos permanentes, destinadas a las reuniones de los gobernadores y miembros del grupo militar (cuya etnografia presento en el capítulo VI) y otras dos enramadas de carrizo fresco - una al oeste, frente a la iglesia y la otra al este - que se construyen exprofeso para cada fiesta. Esta organización corresponde al tipo centro-ceremonial (Gimate-Welsh 1999).

A su vez, el tebat está circunscrito por un camino de tierra que circunda la iglesia y sigue por la periferia externa de la plaza, se trata del conti vo'o, el camino de la cruz, el cual está marcado por catorce cruces de madera que permanecen ahí todo el año y que pueden asociarse a las estaciones del viacrucis. La séptima, que recibe el nombre de calvario, se distingue por las tres cruces que ahí se levantan.

1 Ver el análisis de Schechner en Crumrine y Spicer en prensa. 


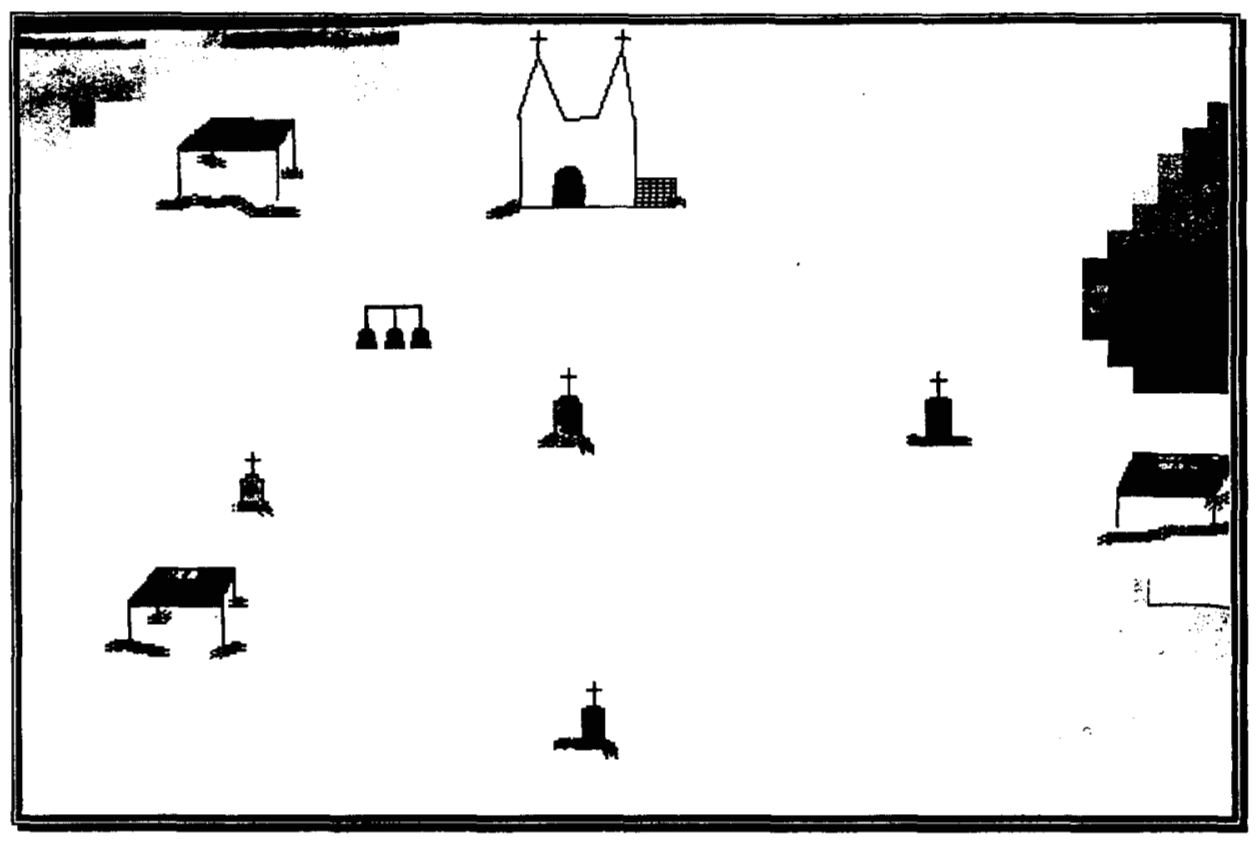

El espacio circundado por el conti vo'o también se considera el sitio privilegiado de la actividad social y política, pues la gente se detiene para saludarse y "visitar a la cruz"; y dado que alberga las enramadas de la comunila y de la guardia, es también el punto donde confluye la autoridad. Esta cualidad de escenario en las reuniones de "los jefes", contrasta con su destino en Semana Mayor, cuando sentados en la cruz del perdón, los enmascarados reciben ahí la limosna. En este sentido, el tebat de Vícam Pueblo merece una mención aparte, en virtud de ser la sede del Cuartel General de la Tribu Yaqui, esto es, el punto de reunión de los ocho cobanaos, representantes del gobierno tradicional.

Los marcadores del espacio sagrado, en todos los casos, son las cruces. Todas las ceremonias y procesiones en el tebat están presididas por una, igualmente, se levanta una cruz en el umbral del solar doméstico recién ocupado y, como presentaré más adelante, las cruces, kusim, ocupan un sitio privilegiado en la parafernalia e igualmente como arma frente a la envidia y la hechicería. 
Según el testimonio de un maestro litúrgico, "la cruz puede mirar en cualquier dirección, pero nunca viendo al oeste; es mejor al este". Mi observación es que las cruces siempre se orientan hacia la sierra, hacia donde sale el sol y que corresponde al este.

De manera que si la cruz está al centro, lo que está más allá es el pueblo; si el pueblo es el centro, lo que está más allá es la sierra, el mar, el mundo yori y el desierto; más aún, si el mundo humano corresponde a los pueplum, lo que está fuera del universo sagrado cultural yoreme es el huya aniya, el monte, el universo sagrado natural, habitado por los surem, el choni, la serpiente kurues $y$ los animalitos del monte.

En el centro de este centro está la iglesia, el teopo. Las iglesias yaquis son construcciones que, aunque varían significativamente en cuanto a su antigüedad, repiten en lo esencial, la estructura románica: macizo axial y dos torres. Lo que resulta en una planta en forma una cruz cuyas torres están coronadas, a su vez, por cruces. Por dentro, carecen del mobiliario que caracteriza a los templos católicos mestizos y las imágenes religiosas se reducen a las dispuestas en el altar principal y los dos secundarios.

La posición de las figuras sagradas de los altares sigue reglas explícitas: mientras las figuras masculinas, Itom Achai, el Cristo crucificado, que solo puede ser tocado por el maestro y los temastianes ocupa el centro y la derecha del altar; las advocaciones de la Virgen ocupan el lado izquierdo, las imágenes de María son transportadas y cuidadas por las kiyohteis, asistidas por otras mujeres del teopo ya'ura, cofradía que agrupa a todos aquellos que cumplen una promesa.

Unicamente la Virgen de Guadalupe, siendo una figura femenina, puede colocarse a la derecha, costado reservado a las figuras masculinas, por ser patrona de la guardia militar, ámbito de autoridad compuesto exclusivamente por varones. 
IGLESIA

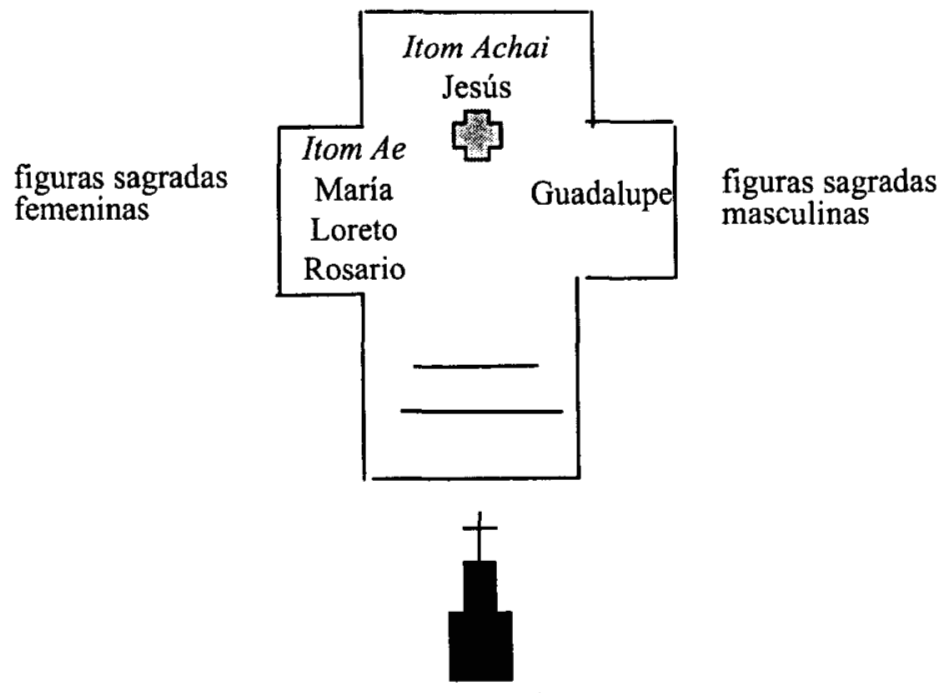

Varios mitos sancionan esta distinción, uno de ellos relata cómo Jesús, un hitebi o curandero yaqui que recorría los pueblos haciendo su trabajo tekia, en un tiempo en el que sus habitantes ya eran cristianos, ocupa el sitio de héroe cultural al ser responsable del origen de las danzas de pascola, venado y coyote. Por su parte, María es la patrona de los Matachines, quienes se autonombran Itom Ae sontaom, los soldados de la Virgen.

Los espacios centrales y sagrados así construidos son lugares donde se despliega el ritual público y además, donde se pone de manifiesto la tensión inherente a este sistema bipolar. Este sistema, articulado en torno a categorías propias a una diversidad de lenguajes como el posicional y el mítico, tales como izquierda y derecha, Jesús y María, Itom Achai e Itom Ae, baña prácticamente la totalidad de las expresiones culturales de este pueblo.

Sin embargo, dicha tensión tiene que ser resuelta de una u otra manera, mi hipótesis es que el espacio - tiempo de la fiesta, mediante las palabras y los gestos, revive en un plano expresivo el drama étnico que constituye el nudo en 
la vida de los habitantes de los ocho pueblos. Es en el ritual donde se resuelven, en otro idioma, las distinciones materializadas en los registros descritos. 


\section{¿QUÉ ES UN PAHKO?}

El espacio así descrito cobra sentido no sólo como escenario del rito -auténtica unidad espacio-temporal-, sino como uno más de los actores del mismo. Dicha unidad está fijada por los movimientos, que consisten en gestos, recorridos y danzas principalmente, a partir de los cuales se cumple un ritmo definitorio.

La etnografía de una fiesta particular permite, desde esta perspectiva, dar cuenta no sólo de un determinado "uso" del espacio y del tiempo, sino cómo ambas categorías representan, en el marco del rito, los dos polos de un mismo principio.

Parto de la descripción de una fiesta particular, que considero representativa, como la que tiene lugar del 14 al 16 de julio de cada año, cuando los pescadores de Las Guásimas celebran el día de su patrona, la Virgen del Carmen. La fiesta o pahko son los nombres que se emplean, a mismo término, para designar la unidad del ciclo ritual y se distingue de otros ritos que se acercan más al carácter profano y que se definen como los bailes. Por lo general, fiesta y baile son excluyentes y sólo en algunas ocasiones ocurren simultáneamente, como en algunas fiestas patronales, jamás durante la cuaresma. Se trata de eventos completamente distintos y aún en el caso de ser simultáneos en el tiempo, nunca lo son en el espacio: el tebat se consagra a la fiesta sagrada. El baile, que puede realizarse con motivo de un cumpleaños, una graduación o una despedida se distingue por llevarse a cabo en los solares domésticos o en terrenos periféricos del poblado, acompañado siempre por música comercial ejecutada en vivo o grabada, dura una sola noche $\mathrm{y}$, por lo general, termina con un pleito o conato de pelea.

La fiesta o pahko es en definitiva un evento de carácter sagrado, y no obstante su diversidad, pueden identificarse en todas ellas tres elementos constantes: la víspera, la misa y el conti.

La proximidad de una fiesta, en cualquier poblado, se adivina por la presencia de un grupo de varones que trabaja en equipo construyendo la enramada con carrizo fresco; otro grupo que se encarga de adquirir una o más reses para el consumo durante los días de fiesta y el grupo de las mujeres que se 
compromete a colaborar con las labores en la cocina y en la iglesia, todos ellos coordinados por los fiesteros o pahkome.

Las vísperas, hipsa, tienen lugar siempre que hay una fiesta y al igual que la mayoría de los ritos, son conducidas por el maestro, las cantoras y el temastian. En ocasiones, las vísperas se transfieren al sábado o domingo más cercano y también tienen lugar en las fechas móviles como Trinidad y Corpus. Las misas son conducidas por el maehto, con la ayuda de las cantoras y el temastian, y tienen en común con la misa católica únicamente la parte del servicio que puede conducir un laico.

Cada fiesta se inicia al atardecer, y aunque aparentemente éstas transcurren a lo largo de tres días solares, en realidad se trata de dos días rituales: la víspera y el día de fiesta propiamente dicho. Los cohetes de trueno lanzados por los danzantes de pascola y las llamadas a golpes de tambor son los marcadores temporales de las secuencias de la fiesta.

Del lado de la Iglesia y al pie de una cruz se instala bajo su enramada la tropa de Matachines, los Soldados de la Virgen, junto con los músicos respectivos, el grupo de cantoras y el temastian. Al frente, del lado este y también bajo su enramada el moro y sus danzantes, pascola y venado con sus músicos y el grupo de cocineras.

Los responsables del desempeño de la celebración son los dos grupos de fiesteros, el pahkome, divididos en el bando rojo y el bando azul, cuatro hombres y cuatro mujeres en cada uno. Esta disposición espacial de la fiesta marca las series izquierda y derecha, este y oeste, valle y sierra, situándose el propio tebat y la fiesta misma como el centro. Esta disposición está señalada por un rito negativo: la prohibición expresa de atravesar este espacio por el centro. Durante la fiesta, todos aquéllos que deseen pasar de una a otra enramada deberán rodear el espacio delimitado por las cruces.

La tensión así reflejada se resuelve únicamente en dos ocasiones: 1) cuando los fiesteros transportan los alimentos de una enramada a la otra, actividad que está mediada por ritos específicos y 2 ) en el momento culminante de la fiesta, el conti o procesión final. 


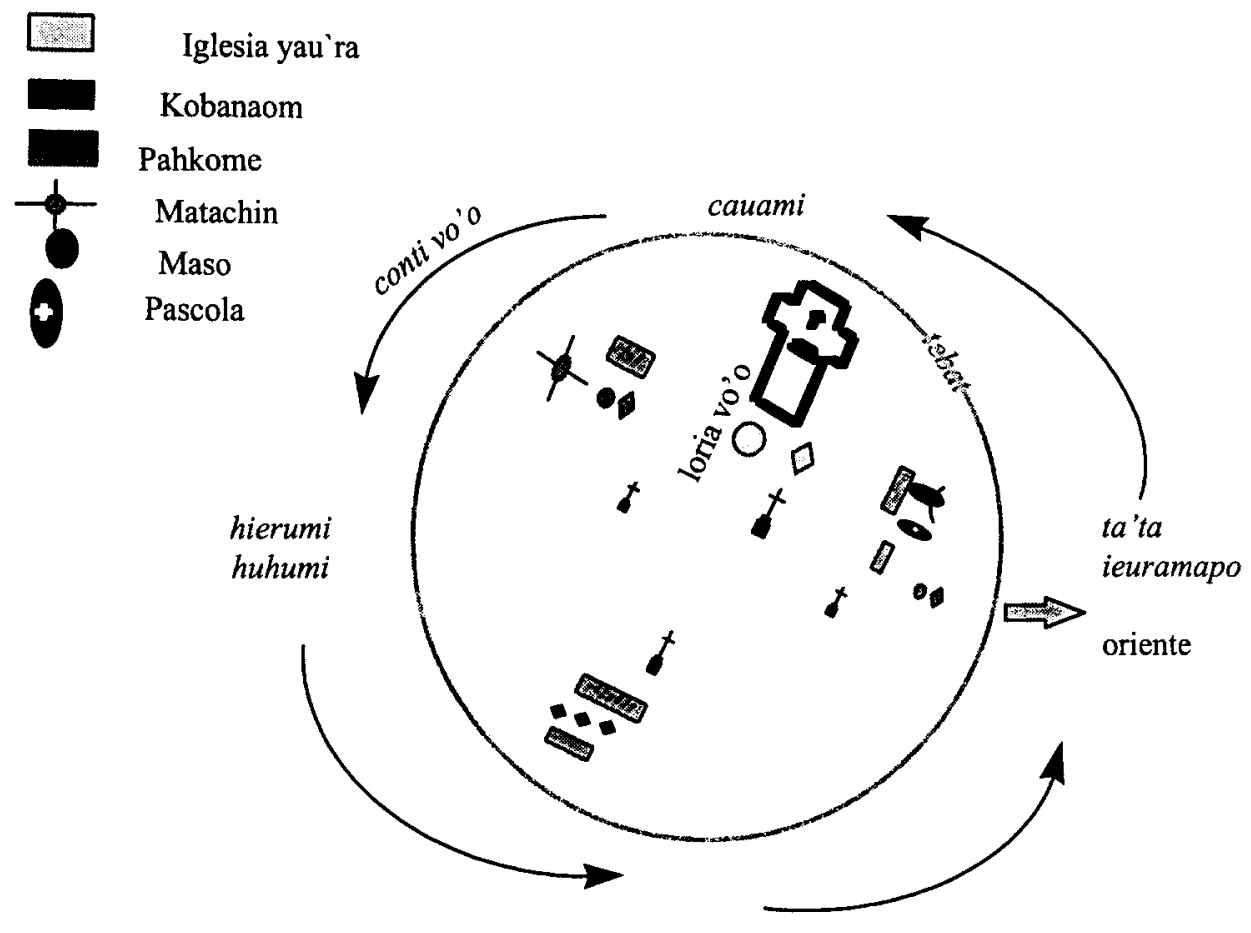

tenami

Así dispuestos, los términos de este encuentro se definen no sólo por su ubicación espacial; venado y pascola, al este, toman cervezas y fuman constantemente en lo que constituye una prescripción que acompaña su conducta irreverente y el lenguaje procaz que emplea el pascola, oponiéndose a la estricta prohibición que en este sentido recae sobre los Matachines, quienes no sólo no pueden beber alcohol sino que deben guardar abstinencia sexual, discreción en el lenguaje y en la conducta, mientras llevan "puesto el traje de la Virgen". Por su parte, los Matachines, junto con el maestro litúrgico y las cantoras forman parte del grupo de la Iglesia, mientras que su contraparte no está organizada en una compañía; el maso y sus coyotes o, venado y pascolas, actúan individualmente, invitados por el moro, mientras que los Matachines asisten al llamado de su monaha, el monarca de los matachines, para hacer su trabajo, tekipanoa, es decir, orar para ganar indulgencia. 
Así, la danza de Matachines quedará asociada con la Virgen, representante del mundo sagrado cultural, conocido como sewa, flor, gracia, indulgencia. Los pascolas y el venado se identifican con la vivencia sagrada natural, del yoania, noción que alude a la relación con el mundo de la surem, a través de las hormigas, las lagartijas, las serpientes y el chivato (los animalitos del monte presentes en su parafernalia y en la letra de los sones). Al momento de realizar su danza grupal, los Matachines son acompañados de alabanzas sin canto ejecutadas por músicos de violín y guitarra; las cantoras cantan alabanzas $\sin$ acompañamiento, mientras que el Maestro litúrgico, ora verbalmente. Frente a ellos, pascola y venado bailan sones, el venado acompañado por tambor de agua, raspadores y canto, el pascola sin canto pero acompañado alternadamente por violín y arpa, o por tambor y flauta.

\begin{tabular}{|c|c|}
\hline Oeste & Este \\
\hline Soldados de la Virgen & Asociados al yo'chivato \\
\hline Pertenecen a un ya'uram & No pertenecen a un ya'uram \\
\hline Iniciación formal & Iniciación esotérica \\
\hline $\begin{array}{c}\text { Comunican con el mundo } \\
\text { sagrado cultural sewa }\end{array}$ & $\begin{array}{c}\text { Comunican con el mundo } \\
\text { sagrado natural yo'ania }\end{array}$ \\
\hline Música y danza & Música, canto y danza \\
\hline Conjunto de cuerdas & Tambor y flauta \\
\hline Oran en silencio & Divierten hablando \\
\hline Baile grupal simultáneo & Baile individual sucesivo \\
\hline Actitud de recogimiento & Actitud de esparcimiento \\
\hline Abstinencia de alcohol & Prescripción de alcohol \\
\hline Abstinencia sexual & Lenguaje con referencias sexuales \\
\hline
\end{tabular}

Aunque la iniciación de ambas clases de danzantes se caracteriza por el intercambio de dones y favores que caracteriza las mandas o promesas; el Matachín descubre su vocación mediante sueños asociados a la Virgen o ancianos benefactores, mientras el Pascola descubrirá su pertenencia al yoania al evocar mediante sueños o, por el contrario, la vigilia prolongada en sitios apartados de la sierra, a los animalitos del monte. 
Si en la primera secuencia que corresponde a la víspera, se suceden ininterrumpidamente las danzas, la secuencia posterior está definida por la alternancia de contis y misa. La procesión o conti significa literalmente "ir alrededor de" o como los propios yoremes traducen "salir a caminar". El conti inicia cuando ingresan a la Iglesia los pascolas, venado y moro junto con el tampaleo, quienes se colocan en medio de las dos filas de matachines. El maestro, las cantoras y kiyohteis se ubican en la parte norte de la Iglesia con la imagen de la Virgen del Carmen, al salir de la Iglesia, cada grupo; pascola, venado y matachines ejecutan su propia música simultáneamente, al tiempo que el maestro y las cantoras cantan y rezan. Conforme avanza la procesión, en sentido antihorario, los pascolas hacen movimientos hacia adelante enfrentando la imagen y retrocediendo, cada vez que lo hacen las tenanchis - jóvenes solteras iniciadas en el teopo ya'ura- agitan las banderas rojas y azules haciendo la señal de la cruz.

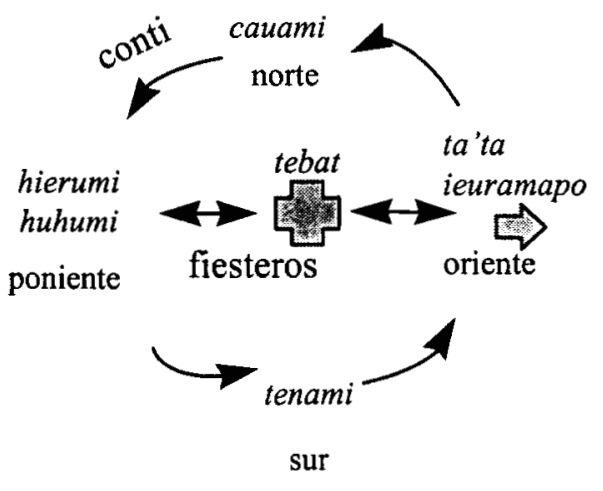

La procesión continúa hasta detenerse fuera de la Iglesia, a la altura de la cruz del perdón, donde permanece mientras se lanzan cohetes y se quema un castillo en honor a la Virgen. Al finalizar la quema del castillo el grupo se dirige hasta el altar que está en la enramada de los pascolas, donde se coloca la imagen de la Virgen y finaliza el conti. 


\section{ENRAMADA}

$\mathrm{E}$

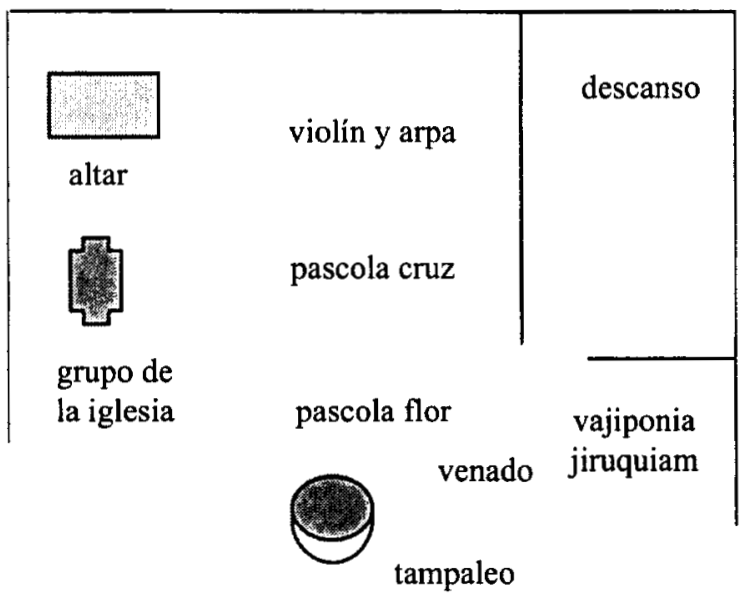

Ahí permanecerán orando toda la noche las cantoras y el maestro, al tiempo que los danzantes ejecutan sus danzas. Al amanecer, los matachines celebran una danza especial en honor a la Virgen llamada trenzado. Al mediodía se lleva a cabo la misa. Al caer la tarde se realiza el último conti, en el cual los participantes se ubican en el mismo orden que en la primera procesión, solo que esta vez portarán dos imágenes, una de la Virgen de Rosario, patrona de los Matachines y otra de la Virgen del Carmen, la procesión avanza hacia el oeste, hace tres estaciones frente a las cruces y una cuarta frente a la Iglesia.

Este gesto lo repiten las jóvenes bantelo al agitar las banderas tres veces hacia las cuatro direcciones, en nombre de la Trinidad Bahi Diosta, Dios Achai, Dios u'usi, Dios Espítu Santo. Con este movimiento se sacraliza el espacio y "se ahuyenta al diablo de las fiestas". También las imágenes se elevan en dirección a los cuatro puntos cardinales hasta que la procesión ingresa finalmente a la Iglesia dando por terminada la fiesta. 
Es en la etapa de agregación de la fiesta, marcada justamente por las últimas danzas y la procesión conti, que se restablece la unidad ideal del universo simbólico y cultural. Esta secuencia postliminar requiere de la restauración del orden anterior a la fiesta, para lo cual se borrarán las oposiciones que fueron resaltadas en las fases anteriores del ritual. Así, para el pensamiento yaqui, la fiesta restituye el ritmo social y cosmológico propio de la sociedad, al considerarse a sí mismos como producto de una relación original e inextricable entre la visión aborigen del mundo y la doctrina católica, los yaquis se representan como la procesión misma donde se reúnen, por única vez, el Matachin y el Pascola, la música de tambor y flauta con la de violín y arpa, el grupo de la iglesia y los laicos, la sierra y el valle, la izquierda y la derecha, Jesús y María.

La combinación de dos tipos de movimiento, el oscilatorio este/oeste entre los bandos de las dos enramadas y el elíptico de la procesión, definen un espacio, y en esa medida materializan las marcas y las direcciones significativas en términos de sus valores.

El rito se presenta de esta manera como el lugar donde corresponden una percepción del mundo, materializada en el registro espacial (estático) del tebat, que sirve como base del recorrido (dinámico) oscilatorio y circundante de los participantes, hacia determinadas direcciones - verdaderos punto de conexión con el mundo- dando lugar así a una representación, un mito, en el que se representa cíclicamente un drama étnico.

Con base en este planteamiento, que resumo gráficamente a continuación, procederé a describir el polo temporal de este modelo, que corresponde a la etnografía de la actividad ritual que se desarrolla en los ocho pueblos, en el lapso de un año solar. 


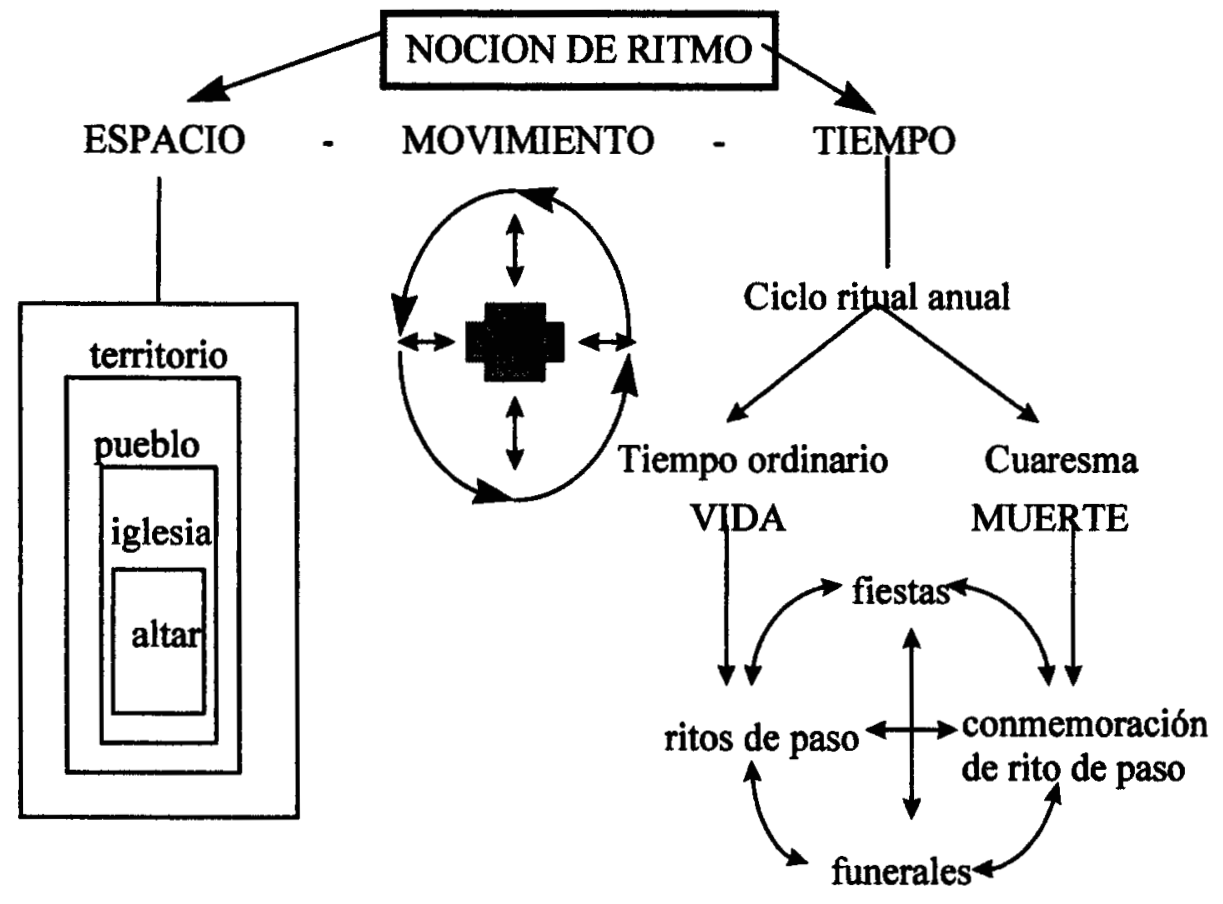


ETNOGRAFÍA DE UN AÑO RITUAL 


\section{PRINCIPIOS SINTÁCTICOS DEL CICLO}

La dimensión preferentemente temporal de esta proposición -que corresponde al ciclo ritual anual - es, desde el punto de vista de su sintaxis, un rito único que se desarrolla a lo largo de un año solar. Con base en la información etnográfica considerada, parto de que el calendario ritual y festivo, la organización temporal y espacial de las fiestas y la orientación de las construcciones rituales entre otros aspectos, tienen un carácter derivado de su posición necesaria al interior del sistema.

Como conjunto heterogéneo de tradiciones, cuerpos de conocimiento y restos y sobras provenientes del conocimiento tradicional indígena, el occidental, la tradición judeocristiana y la medieval, su carácter necesario está dado por la estructura de relaciones que lo sustenta. De manera que el mosaico del conocimiento tradicional sobre la naturaleza del tiempo, reconstruido sobre la base de la información disponible, permitirá, en su momento, proceder a la interpretación de la cosmología como sistema de proposiciones (capítulo V).

La reconstrucción etnográfica del ciclo ritual parte de que se desconoce prácticamente todo, o de que la información con que se cuenta es tan fragmentaria o está dispersa a tal punto en la etnografia, que es necesario partir de cero. Sobre esta base, considerar al registro etnográfico como valioso en sí mismo, ha facilitado la reconstrucción del calendario ritual yaqui a partir de la observación directa de las festividades que tienen lugar en los ocho pueblos y otras localidades, así como de la información etnográfica recopilada entre la población.

El primer paso ha sido la reconstrucción sintagmática del calendario completo, considerando como criterio unificador la participación de individuos yaquis, ya sea en el nivel doméstico, gremial, local, étnico e interétnico en el ritual conocido como pahko o fiesta, cuyas secuencias identifiqué en el capítulo tercero. 
El cuadro a continuación representa el resumen de un año de observación de las fiestas en las comunidades yaquis. Cada fecha significativa ha sido ordenada sucesivamente de acuerdo a la cuenta solar, considerando que el inicio del año litdrgico para los yoremes lo marca el día de la Santa Cruz o Kusim Taewa.

La observación atenta de este cuadro permite identificar el calendario ritual como un sistema clasificatorio original, en el que se relacionan, si se observa cada columna como un conjunto:

a) una serie calendárica de fechas asociada ya sea a un principio solar, lunar o semanal

b) un conjunto de conceptos religiosos ligados a nombres de santos, vírgenes y eventos relacionados con la vida, muerte y resurrección como un bebé de Jesús ${ }^{1}$

c) un conjunto de puntos localizados en la geografía y geografia sagrada; y finalmente

d) un conjunto de eventos rituales específicos asociados a la participación de los yoremes en las sociedades ceremoniales que rigen la vida política, civil y religiosa.

Además de proporcionar un itinerario temporal en el que cada fecha representa un hito en el dominio de la sucesión, el calendario en sí mismo refiere una cosmología. Al relacionar por lo menos cuatro órdenes de la actividad colectiva, el ciclo ritual así presentado suministra un principio clasificatorio para el mundo yaqui, si se atiende al carácter estacional o no de una fecha, su significado mítico religioso, o bien la naturaleza doméstica, comunitaria o interétnica del rito.

1 El concepto de Jesús es el de un hitebi o curandero yaqui que recorría la tierra sagrada, aún antes del arribo de los misioneros. 

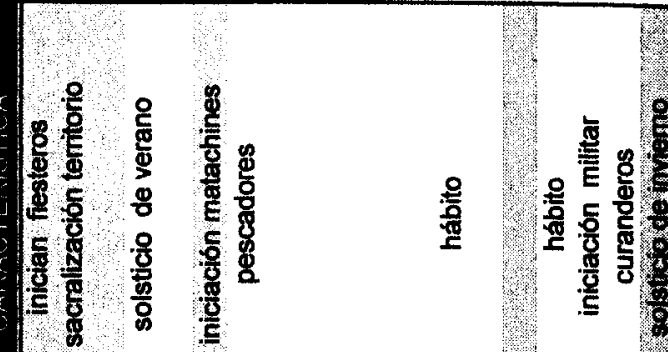

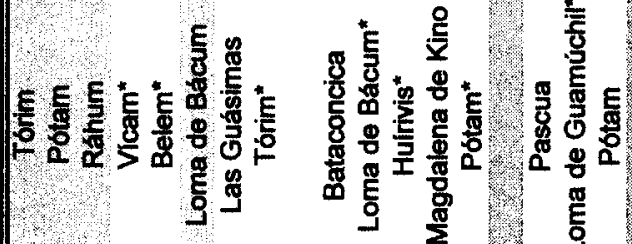

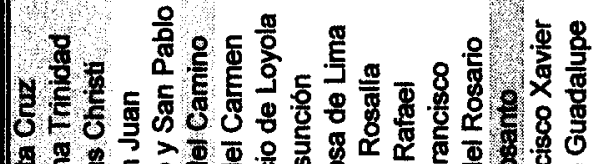

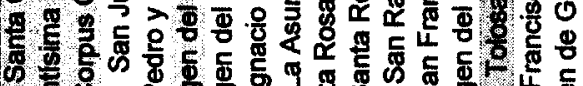

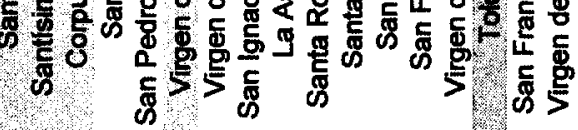

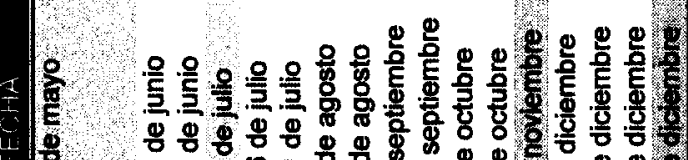

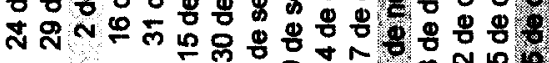
ำ 
El inicio del año litúrgico lo marca el día de la Santa Cruz, el 3 de mayo, seguido por dos fechas móviles, Trinidad y Corpus. La primera corresponde al octavo domingo después de Pascua y la segunda, al jueves que sigue a Trinidad. Estas datas congregan a yoremes de los ocho pueblos y se agrupan en una colección de cuatro fiestas de carácter regional, que culmina el 2 de julio con la víspera de la Virgen del Camino.

La primera fiesta patronal se sitúa un poco antes, el 24 de junio, y es de relevancia mayor, debido en parte a la dimensión urbana de Vícam, su sede, y a que inaugura el ciclo de fiestas patronales. Este ciclo de fiestas de carácter comunitario se sucede en todos los meses siguientes, hasta el lapso que va del primero al 6 de enero, día de la Epifanía, data consagrada al cambio de autoridades civiles. Esta gran temporada dedicada a los santos patrones apenas se ve interrumpida por ritos de índole doméstica como Tolosanto y Navidad.

La Candelaria, última fecha del santoral católico que no puede caer en Cuaresma, es la despedida de los Matachines sewam, flores, y sirve de dique para el tiempo sagrado por excelencia, la waehma.

En este tenor, se distinguen a simple vista los dos grandes bloques temporales que se festejan en el nivel de cada poblado, el primero que inicia en San Juan y finaliza el 12 de diciembre con la Virgen de Guadalupe, con un intermedio preparatorio de la siguiente temporada. A partir de Nochebuena se consagra la actividad ritual al culto del Niño Jesús, para que desde el dos de febrero inicie formalmente la prohibición, el sacrificio, el tiempo de solemnidad a partir del Miércoles de Ceniza increscendo hasta Viernes Santo.

Con el Sábado de Gloria se abandona la atmósfera sacrificial para dar lugar a una irrupción del espíritu carnavalesco, el lapso comprendido entre el Domingo de Pascua ${ }^{2}$ y el 3 de mayo tiene una cualidad sui generis, la cual se definirá a lo largo del análisis.

Así vemos que los dos grandes períodos: el de fiestas patronales (amarillo) y el de Cuaresma - Semana Santa (morado) son anunciados cada uno por breves

${ }^{2}$ Domingo de Pascua puede celebrarse desde el 22 de marzo, su clave anterior, hasta el 25 de abril, la última fecha posible o clave posterior. 
ciclos festivos, de lluvias y dedicado a las tres vírgenes (azul) - Virgen del Camino- el primero, y de Natividad y Epifanía dedicado al Niño Jesús (blanco), el segundo.

Cabe señalar que estos dos breves ciclos preparatorios de las temporadas mayores coinciden con las también breves lluvias que se presentan en la región, en junio las de verano y en enero, las equipatas.

En resumen, la gran línea que separa waehma del resto del año es, en el terreno de las prohibiciones, la de realizar cualquier rito de paso durante los cuarenta días; y en el terreno de la prescripción, el dominio del kohtumbre ya'ura.

Esta perspectiva me permite establecer un diálogo con Spicer (1994) cuya afirmación, en el sentido de que el ciclo ritual yaqui sigue en lo general al calendario litúrgico católico, se ha adoptado casi de manera acrítica por los autores que componen la literatura etnográfica sobre la etnia. Desde mi punto de vista, esta aseveración es evidente "en lo general", no obstante, es posible identificar, a partir de esta reconstrucción etnográfica, una serie de similitudes, pero también de diferencias, entre los calendarios occidental y yaqui.

En primer término, el calendario gregoriano distingue dos conteos, uno "propio de los santos" o santoral y otro "propio del tiempo" o temporal, el cual comprende a su vez los dos ciclos de Adviento y Pascua. Si se toma en cuenta que el inicio del año litúrgico está fijado por el ciclo de Adviento $^{3}$, la importancia de este ciclo en el contexto occidental contrasta con la escasa relevancia que el mismo adquiere entre los yoremes. Si bien la Epifanía tiene significación comunitaria, no es compartida por la totalidad de los pueblos cabecera y el carácter doméstico de la Natividad, la ausencia de celebración el día de la víspera, determina su intrascendencia.

Por su parte, el año litúrgico yaqui inicia el tres de mayo, lo que instaura dos períodos ininterrumpidos, a diferencia de los dos ciclos del temporal montados sobre el santoral en el esquema católico.

${ }^{3}$ Ferrer, León, "El contexto calendárico del Ciclo de Pascua" en Alteridades, año 7 , núm. 13,1997 , págs. $85-88$ 
En ambos calendarios el momento culminante del año litúrgico lo constituye la Semana Santa, independientemente de la significación diferencial de la misma en cada uno de los contextos. En este sentido, la matriz básica de ambos es solar, pero el Ciclo de Pascua tiene una base lunar, ya que la Pascua se define en función de las fases del satélite. El Domingo de Pascua se fija mediante un marcador estacional, que es la primera luna llena posterior al equinoccio de primavera, que corresponde a la temporada de sequía y se consagra preferentemente al culto a la figura de Jesús. Estas dos características corresponden fielmente al calendario yaqui, que distingue entre la Cuaresma Waehma y el tiempo ordinario, la primera está claramente delimitada por el conjunto de prescripciones y prohibiciones impuestas a toda la población, y por marcar un cambio radical en la estructura organizativa de cada uno de los ocho pueblos, con la aparición del kohtumbre ya'ura que asume la autoridad desde el Miércoles de Ceniza hasta el Sábado de Gloria.

Puede decirse que en el calendario católico la Navidad es el eje, el predominio de la cuenta solar sobre la cuenta lunar, aunque el Domingo de Pascua sea la fecha central del calendario. En el calendario yaqui, tiende a predominar la cuenta lunar, tal como lo muestra la excepcional dedicación con que se celebra la Pascua y a que algunas de las fiestas más importantes del tiempo ordinario caen en aquellas datas que no se confrontan jamás con las celebraciones del temporal, tales como el primero y el seis de enero y la Candelaria, el dos de febrero.

Puede entonces sugerirse la hipótesis en el sentido de que la calidad bipartita del calendario yaqui tiene como uno de sus antecedentes la dependencia -anterior al contacto de los pueblos yaquis con el mundo judeocristiano- de las temporadas de lluvias y secas que determinaban el flujo del río y por ende, el establecimiento de las aldeas agrícolas estacionales, este movimiento de oscilación entre lluvia y secas, vida y muerte, tiene su expresión religiosa, como espero probar, en la dicotomía entre tiempo ordinario y Cuaresma.

La distinción del tiempo ordinario y de la waehma tiene una profunda base estacional en la que el imperante tiempo colectivo, sucesivo, continuo, infinito, de oscilación perenne del río queda alterado por la sedenterización forzada en ocho poblados en torno a la misión. Este conflicto, inscrito en la 
memoria de este pueblo, se reproduce en diversos lenguajes cuyo código remite en uno de sus ejes, al carácter estacional del ciclo agrícola.

Esta particularidad obliga a tomar en cuenta el ciclo en su conjunto como una totalidad, puesto que se ha privilegiado la atención hacia los rituales de Cuaresma y Semana Santa (Spicer:1969 y Painter:1950) pero sin abarcar el ciclo completo. Las dos consecuencias metodológicas derivadas de la perspectiva de dichos autores son: la primera, el supuesto de que la actividad ritual se ubica casi exclusivamente en la waehma y la segunda, priva al período regular de un carácter ritual propio con sintaxis y semántica específicas.

La reconstrucción etnográfica de la actividad ritual de un año completo en los ocho pueplum y las localidades yaquis, me permite afirmar que el ciclo comprende un año solar completo y que, sólo al identificar la relación entre el período regular y la waehma, adquiere sentido la expresión temporal del ciclo ritual como un texto único.

Ya que la Cuaresma yaqui se ha convertido en el ritual más estudiado por los etnógrafos de esta sociedad, la interpretación de la waehma oscila entre aquellos autores que privilegian su continuidad respecto de la situación prehispánica y otros que hacen subsidiara a la religión yaqui de las enseñanzas jesuitas. Frente a este estado del conocimiento, lo que refleja la etnografía es la existencia de un sistema original, diferente a las dos tradiciones antecesoras, basado en una creatividad que pone de manifiesto un proceso mucho más complejo que la interrelación de creencias.

Con base en la reconstrucción, fecha a fecha, del calendario, es posible proponer es siguiente esquema explicativo para el ciclo ritual anual yaqui: 


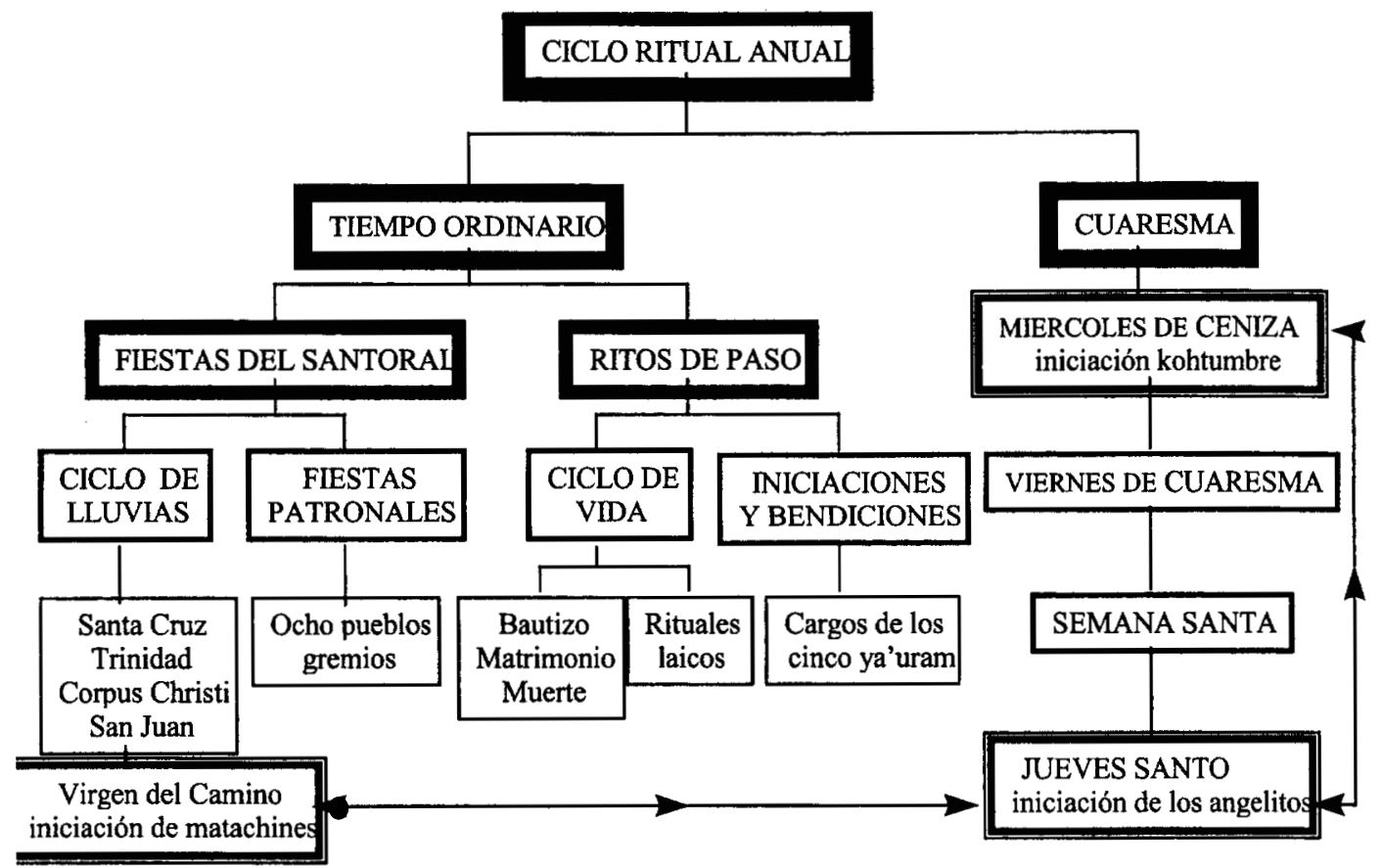

Este esquema concentra todos los ritos y provee un principio clasificatorio idóneo. La división entre el tiempo ordinario de la Cuaresma es básica. El período Cuaresmal inicia propiamente el Miércoles de Ceniza cuando los nuevos miembros del kohtumbre se persignan, ya sea como chapayekas o fariseos; continúa cada viernes de Cuaresma y culmina la Semana Santa cuando el Sábado de Gloria, al cabo de tres glorias, los ángeles vencen al kohtumbre con las flores sewam.

Al tiempo ordinario corresponden las fiestas propias del santoral y todos los ritos de paso que están prohibidos en Cuaresma. Este lapso del santoral, que nombramos así por convención, comprende por un lado, el ciclo de lluvias compuesto por fiestas de carácter regional y por el otro, las fiestas patronales propiamente dichas, que parten de la celebración de San Juan Bautista en Vícam. La fecha más importante de este conjunto es la víspera de la Virgen del Camino, cuando tiene lugar la iniciación de los matachines. 
Como se aprecia en el esquema, al menos tres fechas importantes del ciclo anual están relacionadas con ritos de paso: las iniciaciones del kohtumbre, de la tropa de matachines y de los angelitos. Esta característica nos lleva a pensar que, en general, los ritos de paso individuales juegan un papel importante en el ciclo anual colectivo y vital individual.

A partir del significado y secuencia de cada ritual en el contexto del ciclo anual, se distinguen tres conjuntos:

a) los ritos de paso, en los que intervienen las autoridades religiosas asociados a crisis vitales como el bautizo, alianza y muerte

b) los ritos de paso relacionados con la progresión escolar: graduaciones, quince años, acción de gracias, y son dirigidos por laicos con la presencia de danzantes

c) los que marcan la promesa de un yoreme como autoridad en uno de los cinco ámbitos o ya'uram: fiestero, chapayeka, matachín, maehto, capitán, gobernador o cobanao, dirigidas en su totalidad por el grupo de la iglesia, maehto, cantoras, temastian.

En esta categoría se encuentran también las iniciaciones propias de lo que se conoce como el monte (pascola, venado, tampaleo) cuya expresión se realiza en condiciones esotéricas, después de que les ha sido revelado su destino mediante sueños o bien mediante su contrario, la vigilia prolongada. Aquellos sueños del tenku ania son la revelación onírica del pascola y el venado. Siguen un patrón cultural análogo al del yoania. Mdsicos y danzantes de pascola, venado y coyote son iniciados, después de experimentar un sueño asociado con el arquetipo y de hacer la promesa en una ceremonia formal de carácter privado, fuera de los pueplum y de preferencia en las inmediaciones de los ranchos en la sierra del Bacatete.

En las páginas que siguen, procederé a la descripción de cada uno de los conjuntos rituales en el orden que establece el calendario litúrgico. Para comprender su secuencia y significado más amplio describiré una fiesta representativa de cada conjunto ritual. 


\section{TIEMPO ORDINARIO}

A lo largo de este período o wasuktia tienen lugar dos tipos de conjuntos festivos: por un lado las fiestas del santoral relativas a las fiestas patronales, de gremios y cofradías, y por el otro, los ritos de paso asociados a la vida individual que no pueden tener lugar en la waehma, debido a la prohibición que impera al respecto.

Ambos conjuntos están relacionados en lo que se refiere a su carácter de marcadores temporales, el primero de la actividad comunitaria y colectiva; el segundo, de la vida individual. No obstante, esta distinción no deja de ser formal y por servir al examen, en tanto que es justamente el colectivo quien reconoce la transformación ontólogica realizada en la iniciación, y precisamente en el marco de tales fiestas comunitarias es que tiene verificativo.

Así, en el terreno de los ritos que celebran pasos comunitarios, se distingue el ciclo conocido como de lluvias, no sólo por la cercanía temporal con el meteoro, sino por la naturaleza de los símbolos que ahí se manejan, y por el otro lado, las fiestas patronales cuya marca se reconoce por el patrón secuencial que presentan. La celebración de ambos conjuntos coincide con datas significativas del santoral cristiano.

Entre los ritos de paso que marcan la temporalidad de los individuos se reconocen aquéllos que, por estar asociados al ciclo vital de toda persona se aplican a la totalidad: bautizo, matrimonio, muerte y ritos asociados a la progresión escolar o de edad. Mientras que otro conjunto atañe a una elección individual o familiar, expresada en "la promesa" de formar parte de alguno de los ámbitos de autoridad tradicional o ya'uram, como músico o danzante, a través de las iniciaciones y bendiciones.

Como se observa, el tiempo fuera de la Cuaresma no constituye el "sobrante" del año solar que le sobrevive, sino que se trata de un período con una intensa actividad ritual, comprendido en un lapso establecido de manera expresa, que va del 3 de mayo al 2 de febrero, de cada ciclo. Marcado por la cercanía de las lluvias y bajo el predominio del culto a la figura femenina de María la Virgen, este periodo se sitúa a caballo sobre dos años solares. 


\section{WASUKTIA : RITOS DEL SANTORAL}

\section{Ciclo de lluvias}

En el lapso comprendido del 3 de mayo al 4 de julio tiene lugar el período de festividades más activo del año después de la waehma, el cuarteto constituido por la Santa Cruz y la Virgen del Camino en los pueblos sureños de Tórim y Bácum; Corpus y Trinidad en los norteños de Ráhum y Pótam, indica que al cabo de la primera cosecha se presenta una participación tan amplia como la requerida en ocasión de la waehma.

También relacionado con el ritmo estacional, ya que a finales de mayo los agricultores yoremes empiezan a recoger el trigo de sus campos, este breve ciclo cae justo al inicio del wasuktia, marcado por el tres de mayo con la fiesta de la Santa Cruz en la Loma de Avascaure en el pueblo de Tórim, que corresponde al término del gran periodo de secas en el que caen Cuaresma y Semana santa.

Estas cuatro fechas preparan el evento ritual que congrega a prácticamente la población yaqui en su totalidad, la Virgen del Camino, cuya víspera, el 2 de julio, tiene como sede la Loma de Bácum, el poblado más meridional del territorio y en el que significativamente se ha puesto en juego el conflicto por linderos más álgido y persistente de las últimas décadas.

El día de kusim taewa o de la Santa Cruz en Tórim, marca el inicio del año yaqui. El 3 de mayo es el comienzo del ciclo ritual o del wasuktia ya que en esa fecha o más bien desde la víspera, se lleva a cabo el Levantamiento de la Santa Cruz. La waehma no ha terminado oficialmente para ese día, así que se trata del último día de vida del kohtumbre y el primero del tiempo ordinario. La primera fiesta del año, en la iglesia de Tórim con su gemela en ruinas, es la sede de los yoremes de los ocho pueblos, y declara el debut de los matachines en la escena ritual que durará hasta el día de la Candelaria, despedida de los Soldados de la Virgen. Se espera que después de Pascua los matachines participen en todas las fiestas, pero también que el kohtumbre realice su rezo dancístico en este día de la Santa Cruz. Asimismo, el pahkome o grupo de los fiesteros, hace su promesa este día, en el que los fiesteros de cada uno de los 
ocho pueblos y de las localidades yaquis se persigna para iniciar su trabajo tekipanoa.

Las flores, que el día de Gloria vencieron a los chapayekas, vuelven en esta ocasión, pero ahora para decorar la imagen de la Kusim Taewa y el traje de los matachines. Los matachines portan el traje de la Virgen, ya que se visten de sewa, esto es, de flores nacidas de las gotas de la sangre de Jesús, las cuales cayeron como rosarios kusim.

Entiendo que el concepto de kus sea el invocado para esta ocasión festiva, ya que cumple la función de gozne y entrada a los conjuntos de ritos que componen el wasuktia. La kus, plural kusim, se encuentra presente como unidad de significación, tanto en el discurso como en la parafernalia, el registro arquitectónico y los lenguajes cinético, gestual y mítico.

"El maestro dice que hace mucho tiempo, cuando crucificaron a Nuestro Señor en la cruz y le clavaron la lanza, su sangre cayó en la cruz y ahi se quedó hasta el día de Pascua. Cuando la hallaron, ya eran puras flores. Todo eso lo dice en la víspera de Itom Ae Santísima"

Kus y sewa forman parte de un campo asociado de significaciones que se despliega a lo largo de los 365 soles, o días, en que transcurre la propuesta ritual de los yoremes.

El tercer domingo después de Pascua se celebra Tinidad en Pótam, con el mismo carácter intercomunitario que Kusim Taewa. La Santísima Tinidad: Bahi Diosta, Dios Achai, Dios U'usi, Dios Ephitu Santo.

$\mathrm{Y}$ así como la cruz encarna en rosarios, monumentos, marcas, iconos y manejo del cuerpo y de los cadáveres; la Santísima Trinidad lo hace en banderas. Las bantelo se ondean tres veces en el nombre de la Trinidad desde el centro hacia las cuatro direcciones, y con ello se consigue sacralizar un territorio, un patio o una casa. Gracias a las banderas se evitan los males y se circunscribe un buiata te'ochia, un lugar consagrado.

La siguiente fecha de actividad ritual comunitaria es Corpus Christi, Cohpus en el pueblo tradicional de Ráhum el primer jueves después de Trinidad. 
Mientras que en el calendario occidental Corpus Christi es la contraparte festiva de Jueves Santo, por su posición en el calendario yaqui, Cohpus ocupa el tercer turno de un breve ciclo festivo de cuatro fechas, que culmina con el evento ritual de mayor importancia en cuanto a participación intercomunitaria y profundidad expresiva: la víspera de la Virgen del Camino, el dos de julio.

Esta es la única ocasión del año en que se juntan todos los matachines de todos los pueblos, la suma de aquellos iniciados, activos y retirados por vejez, así como los que se van a persignar ese año en cumplimiento de una promesa expresada de forma personal o por sus padres, o bien heredada de ellos. Ya sea como monaha, malinche o tropa, cada uno de los neófitos se presenta acompañado por sus padrinos para recibir de su compadre, quien le conferirá el mismo cargo, la bendición e insignias correspondientes. La tónica de este rito es el reconocimiento de la tierra sacérrima, el cual se realiza en la procesión que las más altas autoridades yaquis consuman al recorrer por las honduras del suroeste de la Sierra del Bacatete hasta las cuevas de Buatachive.

La fiesta de la Virgen del Camino representa el cenit de un proceso de integración entre los pueblos tradicionales yaquis, que tiene en los matachines el nivel más alto. La mayoría de los iniciados en el teopo ya'ura, cantoras y danzantes de venado y pascola, cubren con su actividad ceremonial un territorio determinado a lo largo del año. El radio de intercambio ceremonial de los matachines es el más amplio de todos desde el punto de vista geográfico, y solamente ellos, entre todas las cofradías de danzantes, participan al unísono todos los años en la celebración de un mismo personaje sagrado en un solo sitio sagrado (cf. "Intercambio ceremonial entre los ocho pueblos" en Spicer 1994).

La preparación para la fiesta anual en Bácum, que impulsa a los matachines de los otros siete pueblos a atravesar todo el territorio yaqui es, literalmente, la sacralización del territorio: "cubrir de flores". Un grupo de matachines de Huírivis por ejemplo, puede iniciar su trabajo ceremonial tekipanoa un mes antes de la fiesta en Bácum y pasar todo el tiempo del recorrido "trabajando" en pahkos domésticos de diversos pueblos. Cada grupo es recibido por el jefe de familia al pie de una cruz alzada de manera temporal en el patio de la casa. Después de depositar la imagen de la Virgen en el altar de la enramada construida exprofeso, obtienen alimento y un albergue transitorio a cambio de 
danzar por lo menos toda la noche en cada una de las visitas ceremoniales que realizan.

Así, todos los matachines avanzan hacia el sur mientras realizan sus tareas ceremoniales y con ello preparan el territorio -en un plano horizontal- que simultáneamente es reconocido por los cobanaos en su marcha hacia las cuevas de la sierra, en dirección abajo - arriba, sede de las imágenes de las tres virgencitas que hacen su visita anual a la iglesia de Bácum.

Si se considera que cada tropa de matachines está formada, al menos, por un monaha, dos o más malinches, un tambor - quien marca los límites entre los pueblos y casas - y entre veinte y cuarenta sontaom o soldados; todos ellos acompañados por las kiyohteim que atienden a la patrona, la Virgen, se espera que la víspera del 2 de julio, en lo que Spicer reconoció como una especie de "devoción nacional", la cifra de danzantes alcance las quince decenas.

Segdn este mismo autor, la Virgen del Camino, nombre que los yaquis dan a Santa Isabel, no es otra que la patrona de Bácum. La leyenda refiere:

"Esta advocación de la Virgen tenía su residencia permanente no en la iglesia de Bácum, cuya patrona era Santa Rosa, sino en un cañón inaccesible de la Sierra del Bacatete, en algdn punto al norte de Buatachive. Cada año era traída en secreto de las montañas, de acuerdo con la tradición, por un grupo especialmente dedicado de Bácum que la colocaba en la iglesia del pueblo." (Spicer 1994:176)

En 1996, la víspera de esta celebración inició desde el 27 de junio para concluir el 3 de julio. Se considera una fecha tan temprana porque ese día comienza la "subida a la sierra" por parte de las autoridades yaquis. Este episodio es de carácter privado y de acuerdo a mis informantes, "los jefes van a traer las tres virgencitas, la mamá de San Martín de Porres, Santa Rosa y la Virgen del Camino que es Santa Isabel". Las tres imágenes son "iguales" y sólo se distinguen por sus atributos: corona, ropaje.

El día de la víspera cayó el primero de julio y dio inicio con la quema de los castillos y la "promesa" de la mayoría de los presentes, entre quienes se encontraban yoremes de Tucson e indígenas de otras partes de México. Su 
término el 3 de julio, también marcado por la quema de castillos, tiene lugar cuando las imágenes de las tres vírgenes son retiradas por los "jefes", para ser transportadas nuevamente a su recinto en las cuevas del Buatachive.

Puede afirmarse que se trata de la única fiesta que tiene por escenario el territorio yaqui en su conjunto, puesto que "todos los matachines se van persignando pueblo por pueblo" ocupándolo en dirección norte - sur. En cada uno de los ocho pueblos, los cobanaos reciben formalmente a cada una de las tropas de matachines que representan a su pueblo y la despiden con un ritual elaborado. De esta manera, durante los tres días de celebración, tiene lugar el punto máximo de actividad ritual, más de cien matachines danzando al unísono, cada grupo con sus músicos durante dos noches.

Cabe recordar aquí, que tal como se identificó en el análisis del registro espacial, la Loma de Bácum representa el punto más alto, en tanto que más oriental, y punto de subida a la sierra, además de intersección con el elemento acuático. Ello explica su elección como ambiente para la recreación del episodio mítico de la marcha de los profetas y de los sobrenaturales yaquis en el origen de la tierra.

En términos de enunciado, el recorrido de los matachines hacia el punto más meridional representa un eje cosmológico en el plano horizontal del seataka o mundo flor. El recorrido que los iniciados realizan hacia lo más alto- la sierra- - para llegar a una cueva en la que están ocultas tres vírgenes, que permanecen ocultas hasta esta fecha y ven la luz sólo durante los días sagrados de la fiesta, representa su contraparte en el plano de la verticalidad. 


\section{Fiestas Patronales}

De los cinco ámbitos de autoridad que actúan en cada pueblo yaqui, cuya descripción a profundidad es el objeto del capítulo VI, es el pahkome o fiesteros quien se encarga de la relación entre el pueblo y los santos patronos. El pahkome se constituye en dos grupos rivales para celebrar el día del santo, en el tebat o plaza central del pueblo, uno al oriente o río arriba y otro al poniente, río abajo.

Spicer afirma que en el siglo XIX se celebraban dos fiestas simultáneas: una en honor del santo patrono de la iglesia y otra en honor del patrono del pueblo (1994:238). A partir de este siglo, este autor observa que en algunos poblados se dio una fusión de santos, o bien no queda claro si se celebra al santo patrono del pueblo o de la iglesia. El siguiente cuadro muestra los cambios en la devoción al santo de la iglesia o al de la fiesta, junto con la designación actual: 


\begin{tabular}{|c|c|c|c|c|}
\hline POBL AD)( ) & $\begin{array}{l}\text { SANTO) } \\
\text { I(iL.ESIA }\end{array}$ & $\begin{array}{l}\text { FIFSTA } \\
\text { 194() }\end{array}$ & $\begin{array}{l}\text { FIISTA } \\
\text { ACTUAL. }\end{array}$ & FHC $H A$ \\
\hline $\begin{array}{c}\text { Vícam } \\
\text { Belem } \\
\text { (Pitahava) }\end{array}$ & $\begin{array}{l}\text { Natividad } \\
\text { San Miguel }\end{array}$ & San Juan & $\begin{array}{c}\text { San Juan } \\
\text { San Pedro y San } \\
\text { Pablo }\end{array}$ & $\begin{array}{l}24 \text { de junio } \\
29 \text { de junio }\end{array}$ \\
\hline Bataconcica & Santa Rosa & Santa Isabel & $\begin{array}{l}\text { Virgen del } \\
\text { Carmen }\end{array}$ & 16 de julio \\
\hline Las Guásimas & & & $\begin{array}{l}\text { Virgen del } \\
\text { Carmen }\end{array}$ & 16 de julio \\
\hline Pascua & & & San Ignacio & 31 de julio \\
\hline Loma & San Ignacio & San Ignacio & $\begin{array}{l}\text { San Ignacio } \\
\text { Santa Rosalía }\end{array}$ & $\begin{array}{l}31 \text { de julio } \\
4 \text { de }\end{array}$ \\
\hline $\begin{array}{l}\text { de Bacum } \\
\text { Magdalena* }\end{array}$ & & & San Francisco & $\begin{array}{l}\text { septiembre } \\
4 \text { de octubre }\end{array}$ \\
\hline Huírivis & Santa & Bárbara & San Rafael & $\begin{array}{c}29 \mathrm{de} \\
\text { septiembre }\end{array}$ \\
\hline Pótam & & Trinidad & $\begin{array}{l}\text { Virgen del } \\
\text { Rosario }\end{array}$ & 7 de octubre \\
\hline $\begin{array}{l}\text { Loma } \\
\text { de Guamúchil }\end{array}$ & & & $\begin{array}{l}\text { Virgen de } \\
\text { Guadalupe }\end{array}$ & $\begin{array}{c}12 \mathrm{de} \\
\text { diciembre }\end{array}$ \\
\hline
\end{tabular}

La secuencia del pahko es característica de los ritos fuera de la waehma: las dos secciones en que se divide la población participan igualmente a resulta de la promesa que anteriormente se ha establecido por uno o tres años. Los responsables de la organización y administración de las fiestas son dos grupos, los rojos y los azules, formado cada uno por ocho miembros: cuatro varones y sus esposas o compañeras. Este grupo ha sido elegido el día de Kusim Taewa y asistido por parientes y parientes rituales se encarga de la comida, cohetes y efectos necesarios. La fiesta dual es propia tanto de la fiesta patronal como del pahko doméstico.

Cada una de las fiestas patronales presenta una secuencia más o menos similar, cuyos rasgos generales son los siguientes. Las ocho parejas de fiesteros, cuatro del bando rojo y cuatro del bando azul, son elegidas con un año de anticipación. Una semana antes de la fecha señalada para la fiesta, los 
fiesteros vigentes amarran a quienes serán sus sucesores, a quienes se persigna y coloca un paño sobre la cabeza, de color rojo o azul según les corresponda. Durante un año los recién electos sólo se dedicarán a observar y hasta el último día recibirán formalmente su cargo y compromiso. Cada fiestero eligirá a su vez a una compañera para que lo auxilie, y de la misma manera cada fiestero y fiestera amarran cuatro moros, quienes cooperarán con trabajo y provisiones para la fiesta. A lo largo del año los fiesteros preparan con tiempo suficiente los platos y tazas de barro, petates, manteles, servilletas, cohetes, velas, dinero para la compra de una res que se sacrificará en la fiesta y una cantidad semanal destinada a la compra de juegos pirotécnicos.

Cuando se aproxima la festividad, los fiesteros azules construyen una enramada de carrizo del lado de la iglesia y los rojos al otro extremo. Aunque las enramadas varían en cuanto a tamaño y distribución, todas contienen los mismos espacios: el almacén de provisiones junto al que se ubican las hornillas y cumple la función de cocina, el altar y el recinto en que se ejecutan las danzas. Dos días antes del evento los fiesteros llegan a la enramada, para no abandonarla sino hasta un día después de terminada la fiesta. Durante este tiempo se cocina y ofrece comida a todos los asistentes.

Las secuencias correspondientes a este tipo de fiesta corresponden a las descritas en el apartado "¿Qué es un pahko?" La alteración del orden cotidiano es evidente, pues los danzantes, fiesteros, teopo ya'ura, cocineras y todos los que "hacen la promesa" abandonan sus responsabilidades en el trabajo y en el hogar para cumplir su tekipanoa. Los jóvenes pascolas y venados recién iniciados son sometidos en la víspera a una especie de prueba ante la comunidad, y en la segunda y tercera noches los danzantes experimentados se presentan.

Lo distintivo de estas celebraciones es que concluyen con el traslado de los contingentes a la iglesia para llevar a cabo la última parte del festejo: la pelea de banderas. Este juego ritual consiste en la competencia de dos niños por la posesión de una bandera, posteriormente dos niñas llevan corriendo una imagen de la Virgen y una pequeña campana y finaliza con la huida de los fiesteros azules para no ser atrapados por los rojos antes de entrar a la iglesia. Si alguno de ellos llega a ser alcanzado, sus compañeros deberán pagar como rescate, licor o efectivo. 
Este patrón se repite con pocas variantes, que dependen de imponderables como los recursos económicos y presencia de danzantes, pero que refleja una persistencia y rigidez observada por etnógrafos de varias generaciones.

Como puede verse en el cuadro que resume el calendario ritual, la mayoría de las fiestas patronales cae en las últimas semanas del verano, que corresponde al período de la primera cosecha. Las celebraciones más tardías, como la de Guadalupe en la Loma de Guamúchil, corresponden con un patrón de poblamiento moderno, ya que este poblado sustituyó al de Cócorit, originalmente fundado por los jesuitas y que les fue despojado a los yaquis al cabo de las Guerras.

La información disponible no permite establecer con precisión cómo el calendario ritual se ha transformado después de un largo desarrollo del calendario agrícola propiamente dicho. Spicer (1969) reporta que los cultivos tradicionales de maíz, frijoles, calabaza y tal vez algodón tenían dos cosechas al año y se aprovechaban las inundaciones del río con las lluvias de verano y las ligeras lluvias de invierno. Actualmente, los patrones de cultivo se han transformado, el trigo, la soya, el cártamo y el ajonjolí se cultivan con fines comerciales aprovechando la maquinaria moderna. En los meses de noviembre a enero se siembran trigo y cártamo, levantándose las primeras cosechas en los meses de abril y mayo. El maíz se cultiva dos veces: una siembra de verano y otra de invierno. En los meses de enero a mayo se presenta poca actividad por ser tiempo de secas, en ese tiempo se llevan a cabo los rituales de Cuaresma y Semana Santa que reclaman mucho tiempo y durante los cuales los habitantes de los pueblos yaquis laboran lo indispensable.

El siguiente conjunto festivo con el que da inicio la temporada de fiestas patronales coincide con el solsticio de verano, el día de San Juan, patrono de Vícam. Justo después de Corpus Christi ${ }^{4}$ y antes de la Virgen del Camino, San Juan ${ }^{5}$ es la primera fecha que celebra al santo patrón de un poblado, un

4 Si bien Corpus puede considerarse como la fiesta patronal de Ráhum y la más importante de ese poblado, se le considera parte de las fiestas preparatorias de la Virgen del Camino.

${ }^{5}$ Hay la posibilidad de que al final del ciclo, cada cien años aproximadamente, se junte Corpus con San Juan 
gremio o cofradía y cae precisamente en el pueblo cabecera donde reside el cuartel general de la tribu yaqui.

La relevancia de Vícam es equivalente a la de San Juan, a quien se le conoce como "el padrino de Jesús" puesto que fue él quien " lo llevó al río". En algunas alabanzas se menciona a "San Juan en Jesús compañía" y aparece en los relatos míticos como un acompañante de Jesús, curandero yaqui nacido en el pueblo de Belem, hoy Pitahaya:

"Cuando Jesucristo vivía, no había pascolas. Un día San Juan iba caminando y se topó con el pascola, pero entonces no se llamaba sí, sino Pascual. Entonces San Juan le preguntó que quién era. Y Pascual dijo pues Pascual. Y San Juan lo bautizó como Pascualmente. Entonces cuando la Virgen María lo llamó, le dijo a Pascual que fuera el Sábado de Gloria cerca de la cruz de la iglesia y le dijo que cuando estuvieran juntos todos los fariseos, que se pusiera a gritar cerca de la cruz. Y a la primera Gloria, cerca de la cruz, que gritara para que los fariseos, al verlo, se tardaran en llegar al cielo. Mientras Jesús salía, el pascola se puso a gritar hasta que Jesús salió de la tumba. Y así cumplió el pascola con San Juan y con la Virgen María."

Le sigue en el calendario la fiesta en honor a San Pedro y San Pablo, el 29 de junio en el poblado de Pitahaya, que sustituyó al de Belem cuando éste fue abandonado debido a la sequía. Pedro, a diferencia de Juan el compañero de Jesús, es conocido en los mitos como el que "hace todo al revés". Las máscaras sewa de los chapayekas tienen las orejas largas y puntiagudas porque representan la oreja del soldado que Pedro cortó airado y volvió a pegar al revés $^{6}$. En otras leyendas recopiladas en Arizona, Pedro y Pablo aparecen juntos acompañando a éesds en ese episodio de los evangelios resignificado por el sistema yaqui (Painter 1986:463).

En ocasiones el santo patrón de un poblado lo es a la vez de un gremio o cofradía, como es el caso de los pescadores de Las Guásimas quienes festejan

6 Una breve revisión de los mitos en los que San Pedro aparece como Pedro de Ordimales se encuentra en Olavarria, María Eugenia, Análisis estructural de la mitología yaqui, INAH-UAM, México, 1989:46 y 47. 
a la Virgen del Carmen el 16 de julio, fecha que coincide con la fiesta de Bataconcica. También, la fiesta patronal de la Loma de Guamúchil, el día de la Virgen de Guadalupe coincide con la patrona de la autoridad militar. San Ignacio es patrono de dos poblados yaquis, uno en territorio mexicano, Tórim, $y$ otro en territorio estadounidense, Pascua.

Los días de San Ignacio, Santa Rosalía y San Rafael se suceden a fines del verano en los pueblos de Tórim, Bácum y Huírivis para abrir paso a los festejos en honor a San Francisco.

Tanto para yaquis de ambos lados de la frontera y mayos, como para los o'otham de la región, es importante hacer votos a San Francisco, ya sea en San Francisquito cerca de Magdalena, Sonora el cuatro de octubre, o en la Misión pápago de San Xavier del Bac, en las cercanías de Tucson, a principios de diciembre. Aunque la imagen que se venera es la de San Francisco Javier (antiguo Rectorado sonorense), se le conoce simplemente como San Francisco y no parece haber distinción entre ambos santos.

Esta fecha presenta como particularidad su extraterritorialidad y su carácter interétnico: es celebrada por yaquis de ambos lados de la frontera, mayos, o'otham y mestizos en la antigua misión de Magdalena - actualmente en San Francisquito-, donde murió y fué enterrado el Padre Eusebio Kino ${ }^{7}$. Cada año es destino de peregrinaje, por tratarse de una excelente ocasión para hacerle al santito la promesa de hábito o de escapulario, que consiste en llevar la prenda (generalmente son los niños quienes terminan cumpliendo) hasta por tres años, a cambio de una protección o ayuda en una crisis. La presencia yaqui no se limita a su participación como fieles, cada vez más, músicos y danzantes de pascola y venado son llamados para hacer su tekipanoa y acudir a la peregrinación.

Puede decirse que con San Francisco termina el período fuerte de participación comunitaria en fiestas patronales, siguen en el transcurso del año, la Virgen del Rosario en Pótam, dedicada a honrar a la patrona de los matachines de esa localidad, la Virgen de Guadalupe en la Loma de

7 Un modelo similar de participación se presenta el día de San Francisco Javier en Pascua, Arizona, el tres de diciembre de cada año. 
Guamúchil asociada a la autoridad militar y el quince de diciembre, la fiesta de los curanderos también en Pótam.

Estas fiestas de carácter comunitario que tienen como escenario el tebat o patio sagrado - elemento distintivo de esta categoría de rituales- cesan al término del año solar, para dar lugar a pahko de carácter doméstico, patrocinadas y organizadas por las familias agrupadas en los ho'akame ${ }^{8}$.

${ }^{8}$ Este término es analizado en el capítulo VI, por el momento debe entenderse como unidad residencial de una familia extensa. 
Fiestas de carácter doméstico

Tolosanto y Natividad comparten la estructura del pahko, entendida como la participación conjunta del grupo de la iglesia y una casa o familia, en la organización y administración de la fiesta. Tanto la fiesta patronal como la doméstica comparten esta estructura, pero se distinguen por su escenario y radio de participación. En el pahko se produce la identificación de lo comunitario y lo doméstico al momento en que se comparten símbolos análogos en los registros espacio - temporal y arquitectónico.

La estructura pahko, en que se da la participación conjunta del grupo de la iglesia y una casa, u otro grupo organizado, se pone de manifiesto tanto en Tolosanto y Navidad, como en el funeral de un niño, un cabo de año, las posadas en waehma, la recepción de matachines y las bodas. El escenario es una casa particular, recinto del ho'akame, representado por una pareja, quien acuerda con el grupo de la iglesia los detalles de la ocasión. Este grupo acude desde la iglesia del pueblo, si participan Matachines lo hacen bailando, hasta la entrada de la casa en donde se encuentra la cruz. La casa "toma prestados" los símbolos del tebat: un arco de carrizo, la enramada, el altar y el área de descanso para los pascolas. La bienvenida se realiza en orden jerárquico, el maehto y el jefe de familia intercambian discursos y proceden a depositar la imagen sagrada en el altar. La comida que se reparte en un orden determinado y la sucesión de danzas, son características compartidas con las fiestas de orden comunitario. Antes de la despedida formal, al cabo de dos o tres noches según el caso, se realiza un conti o procesión hacia el patio, que culmina con el agradecimiento de ambas partes por haber permitido el cumplimiento del tekipanoa. En cada ocasión de agradecimiento, lo indicado es el muhte, término que viene de musukte que significa bajar la cabeza, y consiste en inclinarse, hincarse y persignarse frente a un altar o imagen. 


\section{RITOS DE PASO}

Así como el calendario ritual demarca el ciclo que transcurre en la vida de los ocho pueblos, los ritos de paso permiten el tránsito de una etapa a otra en la vida de sus habitantes. Ambos ciclos se encuentran relacionados no sólo por su significación más amplia sino que, en el caso del sistema ritual yaqui, el primero determina el tiempo en que se llevan a cabo los ritos de paso individuales: "Para los grupos como para los individuos vivir consiste en separarse y reconstituirse sin cesar, cambiar de estado y forma, morir y renacer" (Van Gennep 1909:272, traducción mía).

Así, el ritmo individual de la vida de los yaquis se inicia con una sucesión marcada por el bautizo, las graduaciones escolares, los quince años, el matrimonio, y la muerte. Estos cambios en la situación de los individuos no son los únicos, las relaciones entre lo profano y lo sagrado que entran en juego en las iniciaciones de los individuos como miembros de uno de los cinco ya'uram, como danzantes o músicos, también están reglamentadas en códigos especiales, a fin de que la sociedad en su conjunto regule los tránsitos. Un yoreme se persigna cuando él, ella o bien sus padres, deciden establecer el compromiso de ser matachín o cantora, por ejemplo. A partir de entonces, el iniciado no sólo recibe un rosario kusim de manos de sus padrinos, no sólo es reconocido por la cruz, sino que es persignado, es decir, sobre él se repite en tres ocasiones la señal de la cruz: las cuatro direcciones y el centro.

En este sentido, no sólo los individuos se sacralizan o desacralizan, las imágenes religiosas, el hábito, la parafernalia ritual, los espacios domésticos y en ocasiones los vehículos, son objeto de prohibiciones y prescripciones conocidos en conjunto como bendiciones.

Con el fin de sistematizar la descripción y examen reconozco tres conjuntos de ritos de paso definidos por su capacidad de transformación ontológica sobre los símbolos que son objeto del rito:

1) Los relacionados con la situación social de los individuos: nacimiento / bautizo, progresión escolar / graduaciones, alianza / bodas y muerte / funeral - cabo de año. 
2) Los que sancionan la actividad ritual: iniciación de un cargo en el kohtumbre, el teopo ya'ura, pahkome, cobanao y milicia, o bien como danzante o músico de venado maso y pascola

3) Los relativos a la sacralización de espacios, imágenes religiosas, parafernalia y objetos de uso común, conocidos como bendiciones. Éstos consisten en pahkos organizados por los propietarios de una imagen religiosa. Junto con el maehto deciden nombrar al padrino o la madrina, según se trate de una virgen y santa o santo, alguien que "lleve a la iglesia al santito" y que, a diferencia de los cuatro u ocho individuos que requieren las relaciones de parentesco ritual, sólo asista una mujer en caso de vírgenes y santas o un hombre. Los padrinos tienen la obligación de visitar al santo en su día para obsequiarle flores, velas y una oración. 
Ciclo de vida

Bautizo, matrimonio y muerte son los ritos del ciclo relacionados con la situación social de los individuos que tienen como escenario la iglesia, como actores el teopo ya'uram y la tríada padres - padrinos - ahijado. La cristalización de relaciones de parentesco y parentesco ritual, interpretada en cada una de las puestas en escena, se repite en rituales donde la iglesia es sustituida por el solar doméstico y se sanciona la progresión de edad y la instrucción escolar.

Su ubicación en el calendario ritual corresponde al periodo ordinario, fuera de la waehm, $a$ ya que a lo largo de ésta no se puede celebrar ninguno de estos ritos, "ni siquiera las piñatas" (fiestas de cumpleaños). La ocasión para bautizar a un niño se presenta en las fiestas patronales, que son cuando un sacerdote - también yoreme - acude a oficiar la misa previa al conti que pone fin a dichas celebraciones. Sin embargo, no sólo en este registro es que las fiestas comunitarias están relacionadas con la vida personal, el sentido de los símbolos propios de las fiestas patronales, su devoción y referencias en el discurso y la música, evocan al sewa ania o mundo flor, emblema del mundo sagrado cultural al que ingresan los néofitos.

La etnografia de los ritos de paso individuales se presentará en el capítulo VI, el cual está dedicado a la reconstrucción del sistema de actores como sustento de redes entre parientes rituales, a partir de la descripción de una ceremonia de bautizo, de una boda y un funeral/cabo de año, así como de una graduación y quince años. Por este motivo, sólo menciono aquí el carácter general de los ritos individuales como parte de las celebraciones comunitarias determinadas por un calendario/cosmología. 


\section{Confirmaciones}

Cabe dentro de esta categoría los ritos que se llevan a cabo para llegar a formar parte de cualquiera de los cinco ya'uram. Estos ritos constituyen la culminación de una preparación que, en algunos casos como el del maehto, llega a durar varios años.

El cuadro a continuación resume las fechas en que se llevan a cabo las confirmaciones de acuerdo al cargo y ámbito de autoridad:

\begin{tabular}{|c|c|c|c|}
\hline$(\mathrm{ARC} i \mathrm{O})$ & YA'KAM & FECIA & FIISTA \\
\hline $\begin{array}{l}\text { capitanes } \\
\text { azules o rojos } \\
\text { alawasin } \\
\text { moros }\end{array}$ & pahkome & 3 de mayo & Santa Cruz \\
\hline $\begin{array}{l}\text { maestro } \\
\text { temastian } \\
\text { cantora } \\
\text { kiyoste } \\
\text { tenanchi } \\
\text { matachin }\end{array}$ & teopo & 2 de julio & Virgen del Camino \\
\hline $\begin{array}{c}\text { capitán } \\
\text { alférez } \\
\text { teniente } \\
\text { sargento } \\
\text { cabo soldado }\end{array}$ & milicia & $\begin{array}{c}12 \mathrm{de} \\
\text { diciembre }\end{array}$ & Virgen de Guadalupe \\
\hline $\begin{array}{l}\text { cobanao } \\
\text { pueplum }\end{array}$ & civil & 1 de enero & año nuevo \\
\hline $\begin{array}{l}\text { Pilato } \\
\text { capitanes } \\
\text { oficiales } \\
\text { cabos } \\
\text { soldados } \\
\text { chapayekam }\end{array}$ & kohtumbre & $\begin{array}{c}\text { Miércoles de } \\
\text { ceniza y } \\
\text { viernes de } \\
\text { Cuaresma } \\
\text { Curm }\end{array}$ & Cuaresma \\
\hline angelitos & teopo & Yyueves santo & Cuaresma \\
\hline
\end{tabular}


De acuerdo con la afirmación más general, los ritos de paso individuales se llevan a cabo exclusivamente fuera de la waehma; sin embargo, una mirada atenta sobre el ciclo en su conjunto destaca el hecho de que se presentan las siguientes excepciones: la confirmación en el kohtumbre y de los angelitos. Llama la atención que sean justamente estas dos categorías de personajes las que transgreden la norma, puesto que el Sábado Gloria son ambos los protagonistas del combate entre los ángeles, quienes armados de flores sewam, tratan de impedir la entrada de los chapayekam a la "gloria". Este episodio tiene lugar el día concebido como el clímax de la actividad ritual en cada uno de los ocho pueblos, y reviste mayor interés porque involucra a seres de naturaleza liminar: enmascarados y niños. La etnografía de ambas confirmaciones forma parte del capítulo dedicado a la Cuaresma.

La secuencia ritual que se observa en las confirmaciones que caen fuera de la Cuaresma puede observarse mediante los ejemplos de la iniciación de un matachín y del cambio de gobernadores. El primer paso que se da en una confirmación es el establecimiento de la "promesa" por parte del padre, la madre o ambos, en el caso de niños, o bien por el propio joven. Los matachines sólo pueden ser varones, y los motivos por los cuales se ingresa a este grupo de danzantes a menudo tienen que ver con crisis originadas por enfermedades $o$ accidentes de un miembro de la familia o del mismo individuo.

Al momento de prometer a su hijo, los padres lo harán bajo cierto rango, es decir, lo pueden ofrecer como monaha, malinche o soldado. Es importante que en ese momento se establezca la identidad de los padrinos, que tienen que ocupar el cargo para el que fue prometido el neófito. La instrucción requerida en cada uno de los cargos es responsabilidad del paino y la maina, quienes deben socializar a sus aprendices mediante el ejemplo, no sólo en lo referente al aprendizaje de las diferentes coreografias sino en los valores asociados a su nueva investidura.

Llegada la fecha de la confirmación, los padrinos acompañan a su ahijado hasta que es persignado y puede comenzar a hacer su trabajo, tekipanoa. Por lo general son los niños y jóvenes recién confirmados quienes hacen su trabajo la víspera de las fiestas para dar paso, en las siguientes noches, a los más experimentados. 
La fecha de la confirmacion de un matachín, es los primeros días de julio en que se celebra la fiesta de la Virgen del Camino. Ese dia, el iniciado porta el traje de la Virgen (corona, cuello, collar, palma o sewa, rosario o kusim y ayam), este atuendo dependerá del rango que se le otorga, es decir el padrino transfiere su cargo a su ahijado, si éste es monaha o soldado, el ahijado lo será. A partir de ese momento, el matachín está asignado de por vida a su respectivo rango y puede haber sanciones pdblicas en caso de incumplimiento o puede ser expulsado de la "tropa" si la falta asi lo amerita: beber alcohol durante las fiestas o cometer adulterio.

El día que se persigna a un matachín, el resto de los danzantes ya iniciados se encuentra al interior de la iglesia y colocados en formación, mantienen en alto la palma y suenan el sistro o ayam, los padrinos le colocan la corona, un rosario y el paño. Se procede entonces a persignarlo con la imagen de la Virgen del Rosario, patrona de los matachines. Finalmente el individuo ya es miembro de la tropa y deberá danzar cuando se le convoque.

Una vez iniciados, los miembros de los grupos ceremoniales permanecerán adscritos a ellos por el resto de sus vidas, y no sólo serán reconocidos como tales en ocasiones rituales, sino que en la vida cotidiana estarán marcados por causa de su adscripción. Su funeral se distingue del resto, por los honores que el difunto recibe, correspondientes a su cargo y cofradía.

El carácter sagrado de las iniciaciones no es exclusivo del teopo ya'ura, en la milicia ocurre algo similar. Este grupo igualmente toma parte en las celebraciones religiosas y es el encargado de observar el orden y de ejecutar castigos en caso de perturbación o infracción de las reglas marcadas durante las fiestas. 

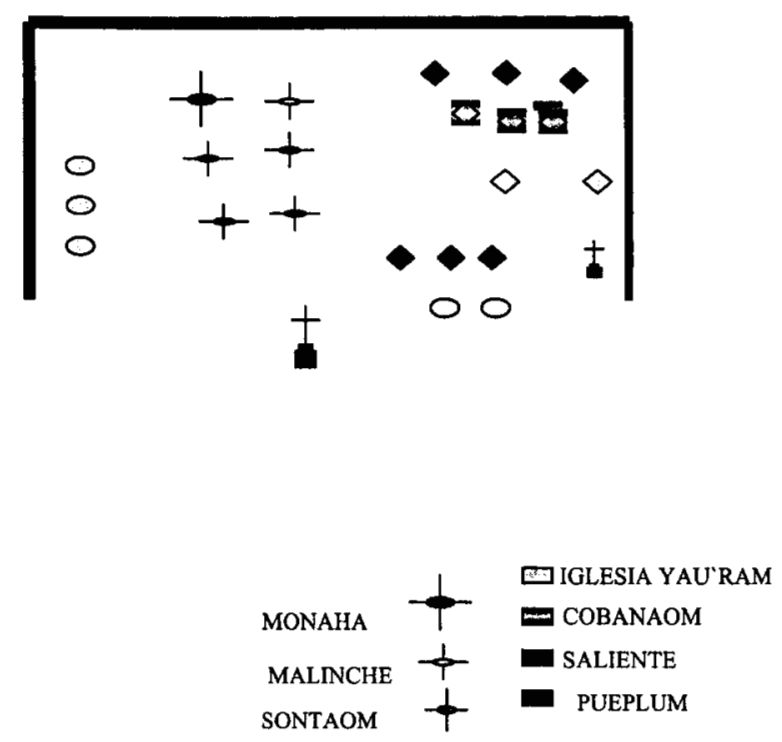

La designación de estos cargos se lleva a cabo en las asambleas del pueblo y su permanencia en el puesto depende de su cumplimiento, eficacia y honradez; no obstante, a diferencia de un ejército regular, no existe movilidad en la jerarquía interna, pues si un miembro tiene un cargo de teniente por ejemplo, asi continuará mientras permanezca en dicho grupo por haber sido persignado por un padrino con el mismo cargo. Esta cofradía tiene como patrona a la Virgen de Guadalupe, cuya fiesta se celebra el 12 de diciembre. 


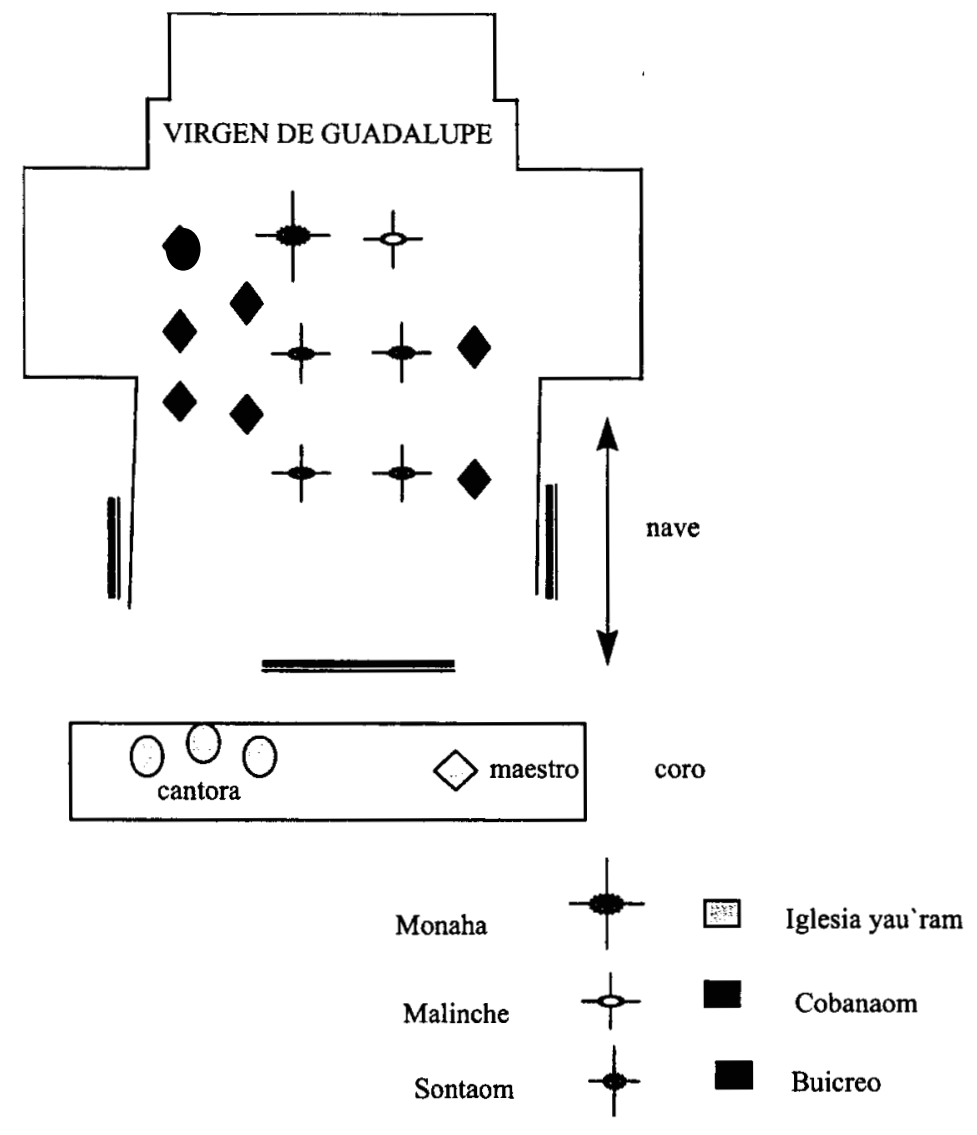




\section{CUARESMA}

Miércoles de Ceniza y Viernes de Cuaresma

Una de las principales características de la waehma yaqui, reconocida por la mayoría de los estudiosos que la han abordado, es su narratividad. En efecto, en el conjunto de ritos que conforman el período puede apreciarse, más que en ninguna otra ocasión ritual del ciclo yaqui, la secuencia de eventos entendida como la representación anual de la caída de Jesús por los Fariseos, su captura y crucifixión, la traición de los Judíos, su destrucción mientras atacan la iglesia y, finalmente, la resurrección de Jesús.

No obstante, este sintagma no puede ser entendido exclusivamente en el sentido impuesto por el credo católico, ya que por principio, como todo texto habría que reconocer su carácter polisémico y sobre todo, que se trata de un paradigma alternativo dominado por la creatividad yaqui. En este sentido, la historia de la derrota de los fariseos, la muerte y ascención de Jesús puede ser reinterpretada sólo si se reconocen sus elementos significativos y se reconstruye el sintagma que le da sentido.

Pero no sólo este episodio narrativo entra en juego a lo largo de la waehma; tal como espero mostrar al cabo del análisis, el conjunto ritual más importante del año yaqui, es también la escenificación de un drama que lleva implícito registros étnicos, estacionales y cosmológicos. En la letra del escritor yaqui Refugio Savala:

"When the trusted disciple commited treachery to his master, Peter, the loyal friend of Jesús, promised to be with him in the worst, and when the soldiers came to get the Lord, Peter drew his sword and struck one of the soldiers and struck off his right ear. Jesús prevented him from going into battle with the soldiers. The Lord took the

${ }^{1}$ Cabe señalar que en los dos períodos de Cuaresma que considero desde el punto de vista etnográfico, no estuvo presente ningún sacerdote católico. Los dos sacerdotes que realizan su labor en los ocho pueblos son hermanos, ambos yoremes, uno de ellos falleció en 1995. 
imputed ear from the ground and placed it back on the soldiers's head, but it was placed on backwards. In this moment the whole army was converted into ugly faces, long ears and noses, and all manner of horrible figures, their weapons into wooden rods, and their tongues were bound up and they could not speak. Jesús said: 'Thou shalt come to me in the last and I will render thee into pretty figures again' But the Pharisees were so angry that they proceeded upon their intentions and crucified him because they said he was a witch and by some sort of enchantment had done this" (Spicer R, y Beals E. en prensa).

La primera parte de la celebración cuaresmal, periodo que abarca el Miércoles de Ceniza, los cuatro viernes y hasta Domingo de Ramos, tiene como núcleo narrativo la búsqueda de Jesús por los hurasim. Jesús es concebido como hitebi o curandero yaqui, quien aún antes de la llegada de los jesuitas, recorría la nación yaqui realizando curas milagrosas entre los enfermos. Actualmente, este episodio se representa mediante la persecución de Jesús por parte de los hurasim y su refugio en casas yoremes mediante las ceremonias conocidas como posadas. Estas fiestas tienen lugar en los recintos domésticos donde, simbólicamente, Jesús se refugia por las noches. Siguen el patrón general de fiesta doméstica o pahko descrita en el apartado correspondiente, excepto por las prohibiciones que entran en vigor en la estación ceremonial de Cuaresma y los requerimientos especiales en lo que se refiere a la elevación de cruces en los umbrales y patios de los solares domésticos.

Preferentemente las posadas se llevan a cabo los Viernes de Cuaresma, al tiempo que tiene lugar una procesión o conti alrededor del Camino de la Cruz o conti vo'o cuyo significado es la búsqueda de las huellas de Jesús. El conti vo'o es un camino de tierra que circunda la iglesia y sigue por la periferia externa de la plaza. Está marcado por catorce cruces de madera que permanecen ahí todo el año y representan las estaciones, en la séptima o calvario, están colocadas tres cruces.

El inicio de este periodo calendárico está señalado por la aparición del kohtumbre el Miércoles de Ceniza. Este evento significa la transformación efectiva de la organización civil y ceremonial de cada uno de los ocho 
pueblos, ya que las autoridades vigentes el resto del año, como los cobanao, la milicia y el pahkome, ceden paso al kohtumbre, quien además de ser el encargado de dirigir las secuencias de la actividad ritual, observa el orden público e impone castigos en caso de infracción.

Formalmente, la vida cíclica del kohtumbre ya'ura, constituida exclusivamente por yoremes persignados, es el período que va de la última luna nueva de invierno hasta la primera luna llena después del equinoccio de primavera, que corresponde a la Pascua. Esta serie de eventos alcanza su clímax dramático la madrugada de Sábado de Gloria, cuando los fariseos se despojan de la máscara y junto con sus padrinos tratan de ingresar al cielo o teweka loria, representado por el altar de la iglesia protegido por una sábana blanca. No obstante, las funciones del kohtumbre se prolongan hasta una fecha tan tardía como Kusim Taewa o día de la Invención de la Santa Cruz, el tres de mayo. Los grupos de autoridad o cinco ya'uram, que durante el período fuera de la waehma gobiernan todos los aspectos de la vida comunitaria en los ocho pueblos yaquis, continúan siendo reconocidos, están presentes en sus respectivas guardias durante las ceremonias; sin embargo ceden el paso al kohtumbre quien decide los tiempos y espacios del ritual.

El kohtumbre está compuesto por dos grupos reconocidos como kabayum o caballeros y fariseos. En el primero, figuran varones adultos que se distinguen por usar ropa de civil, andar a caballo y cumplir la función de vigilar el orden e intervenir en las procesiones. Los caballleros o kabayum son el grupo ceremonial de más alto rango, representan a los guardianes de las imágenes sagradas, las pueplo santoram. Bajo la tutela de su patrón Cristo Niño, los kabayum se ordenan de acuerdo a la siguiente jerarquía: Capitán, cuya insignia es la espada plateada y es el encargado de llevar la limosna; Bantaleo que porta el estandarte; Teniente, Cabo y Sontaom, quienes levantan sus lanzas con puntas de metal plateado el Sábado de Gloria. Entre todos ellos se elige al yo'owe, literalmente el mayor, con base en la edad y experiencia.

E1 papel protagónico lo cumplen los fariseos. Éstos forman un grupo compacto, que permanece al costado oriente de la iglesia, formado por los 
soldados o sontaom, los chapayekam ${ }^{2}$ y los cabos, todos ellos comandados por el Pilato, custodiado por el tampaleo y el flautero. Los cabos son jóvenes solteros que al cumplir la mayoría de edad que se adquiere con el matrimonio, pasarán al grupo de los sontaom, mientras tanto deben obedecer las órdenes de sus mayores. Los tres subgrupos actúan conjuntamente en las marchas - danza consistentes en cuatro diferentes pasos que se repiten continuamente.

La vestimenta es uno de los códigos que permite identificar a los actores de este drama: los soldados o sontaom llevan sombrero vaquero negro (con adornos blancos o negros) y sobre el rostro una pañoleta negra que sólo les descubre los ojos. Encima del pantalón y camisa, portan una capa de color negro que llega a la pantorrilla y una sobrecapa hasta el antebrazo con flequillos blancos, amarillos, dorados o anaranjados. Al cuello un kusim o rosario de madera de torote con borla de estambre y, en ocasiones, una imagen de la Virgen de Guadalupe. En la mano izquierda llevan el puñal y en la derecha el machete o espada, ambos de madera con motivos florales, los jóvenes y geométricos, los adultos.

A excepción del Pilato, que calza botas negras, el resto de los soldados "anda descalzo" esto significa en sus propios términos, calzar dnicamente huaraches de tres puntadas amarrados "a la yaqui". Esta prescripción referente al calzado también opera para los neófitos en ocasión de su "confirmación", así como para los muertos en su funeral.

Los cambios en el atuendo son muy importantes y sólo cobran sentido al considerar las secuencias rituales de la waehma insertas en el ciclo ritual anual y su correlato cosmológico. El más notable de éstos, es el que tiene lugar el miércoles santo o Tinieblah, cuando los pantalones negros de los soldados se cambian por otros de color blanco en la madrugada del jueves santo. Por su parte, es sólo hasta el jueves santo que los cabitos se cubren el rostro, es decir, se ponen "el luto".

${ }^{2}$ La etimología de este término está en discusión. Una versión indica que se trata de los "de orejas largas" 
La indumentaria dominantemente oscura, en especial la capa negra que cubre el traje de pantalón y camisa contrasta, no sólo con la ropa de los otros grupos ceremoniales, sino en general, con la indumentaria que acostumbran usar los yoremes, quienes manifiestan su preferencia por los colores vivos y alegres. El paliacate que todos llevan al cuello, de color rojo, media sobre el hábito negro con fondo blanco o también negro total. La jerarquía del Pilato se refleja en su capa ornamentada con bordados de lentejuela dorada y por ser el único que no anda descalzo.

Los chapayekam tienen una jerarquía interna establecida por la edad, igualmente representada en la indumentaria: los que portan la máscara o sewa tradicional llevan tenavaris enroscados en las pantorrillas, un cobertor de lana ajustado como faldilla y máscaras orejonas; el otro grupo está compuesto por los que llevan máscaras de cuero con la imagen de cholos, payasos o apaches, calzan polainas y trajes variados. Los chapayekas no llevan espada sino bastón, curvo u ondulado, que en ocasiones menean simulando una serpiente.

La conformación del kohtumbre se realiza cada año de manera similar. Al atardecer del Miércoles de Ceniza se escuchan los tambores que llaman a todos aquellos varones yaquis que hayan hecho una promesa por sí mismos, que la hayan heredado de sus padres, o que éstos la hayan efectuado en lugar de los hijos cuando éstos eran pequeños. Deben acudir al llamado y presentarse en ese momento, ya que de lo contrario contraerán un compromiso mayor y tendrán que cumplir con los trabajos más pesados que les asignen los oficiales del kohtumbre.

A partir de este momento se establece una serie de prohibiciones y prescripciones para los integrantes del kohtumbre y la población en general, cuyo estricto cumplimiento se observa con mayor rigor los días que corresponden a la Semana Santa.

La rígida disciplina a que se someten todos sus integrantes tiene como condición la obediencia incondicional de los menores hacia los mayores, lo que convierte al kohtumbre en un importante instrumento de socialización ${ }^{3}$.

\footnotetext{
${ }^{3} \mathrm{~A}$ pesar del gran esfuerzo que requiere ser parte del kohtumbre, ello no impidió que una pareja yoreme prometiera como cabo a su hijo de ocho años de edad, 
Durante la waehma, los iniciados en el kohtumbre no pueden tener relaciones sexuales, beber alcohol, comer carne, dulce, lácteos o alimentos de fácil descomposición y a lo largo del tekipanoa o trabajo ritual, están sujetos a ser zurdos, no pueden hablar y tampoco deben alejarse de la guardia, ya que la transgresión de estas normas es castigada hincándolos sobre garbanzo y azotes en la espalda.

El resto de la población, o la "gente sin cargo" acata las prohibiciones de no ingerir ni comerciar bebidas alcohólicas, no comer carne ni lácteos y laborar lo menos posible. El viernes santo las prohibiciones se incrementan hasta alcanzar la máxima solemnidad durante el conti del atarceder, cuando no se permite llevar ningún tipo de adorno o joya, incluyendo relojes, tampoco se permite que las mujeres lleven el cabello recogido con ningún tipo de lazo.

El ambiente general, no sólo en lo que se refiere a la organización de cada poblado, sino en el tipo de actividad ritual que se realiza, es radicalmente distinto al observado en el período del wasuktia o tiempo ordinario. En la waehma tiene verificativo una transformación de los elementos significativos de las celebraciones ya que tanto los cohetes como la música melódica están prohibidos: únicamente se escucha la música rítmica ejecutada por los chapayekas con su zapateado, entrechocar de armas de madera y el cascabeleo de las pezuñas de venado que cuelgan de sus cinturones. Los cohetes y la música melódica, características de las fiestas, sólo se reanudan hasta el Sábado de Gloria con la explosión del Judas y la interpretación de "Las Mañanitas" y "Las Golondrinas" que los chapayekas dedican al monigote de paja.

El conjunto de ritos conocidos como prohibiciones y prescripciones que operan en waehma están asociadas a un campo de significación más amplio que integra, en primer término, los funerales y de manera adyacente, los ritos de iniciación. Todos ellos enmarcados en un contexto construido por

físicamente discapacitado. Por el contrario, el compromiso y la capacidad de cumplirlo, fortalecen el sentimiento de autoaceptación $y$, junto con el nombramiento de dos de sus primos de la misma edad como padrinos, asegura su participación digna en la vida comunitaria. 
mitos y creencias que serán presentados en la última parte de este capítulo.

Muchos aspectos de la conducta impuesta al kohtumbre tienen relación con el mito de origen de los chapayekas. Sin embargo, el carácter sui generis de los chapayekas no se puede discernir con base únicamente en su descripción intrínseca. Su caracterización como "diablos", "bufones" o "payasos" responde más a un intento por definirlos en sí mismos, que al resultado de un punto de vista sistémico que los ubicaría en su registro espacio temporal y cosmológico.

Mi perspectiva reconoce que la cualidad del chapayeka es precisamente la de situarse en los límites del sistema yaqui. Lo excepcional de la fecha en que tiene lugar su iniciación, en plena waehma, resulta excepcional puesto que, junto con los angelitos, son los únicos ritos de paso que se verifican en la temporada dedicada a Jesús. La prohibición expresa de celebrar ritos de paso en los cuarenta días de luto comunitario es tan extendida, que resulta casi natural que las excepciones se cumplan en el caso de los personajes liminares, y por ello, significativos del sistema: los enmascarados y los niños ${ }^{4}$.

El carácter fronterizo de estos actores rituales se reconoce, sobre todo, en la intersección de dos conjuntos clasificatorios del registro temporal que opera la fecha de su iniciación: waehma y ritos de paso. Así, la iniciación de un chapayeka, es por lo general, un evento que abarca varios años en la vida de un individuo, ya que, aún antes de su nacimiento, los padres de un niño pueden hacer una promesa a Jesús o bien heredar a su hijo la promesa hecha por ellos mismos o sus padres. Este antecedente es suficiente para que el varón prometido sea iniciado $\mathrm{y}$, desde ese momento hasta su muerte, sea reconocido por su cargo.

${ }^{4}$ Este tabú se aplica de manera estricta y no he observado excepciones, por el contrario, el 3 de abril de 1996, miércoles santo, tuvo lugar un eclipse total de luna alrededor de las 18:00 hrs. Este evento, que en condiciones normales hubiera producido actitudes especiales entre la población, pasó prácticamente desapercibido; al año siguiente, la muerte de un bebé en plena Semana Santa no fue objeto de los ritos especiales que se dedican a los angelitos. 
Cada Miércoles de Ceniza y Viernes de Cuaresma, antes de los contis o procesiones que caracterizan a la Semana Santa, los padres del iniciado nombran a un hombre y una mujer como padrinos y juntos se presentan al costado de la iglesia, en la guardia que es el sitio de reunión de los chapayekas. Los padres expresan al kapita yo'owe, capitán mayor, el deseo de prometer a su hijo como fariseo en honor a Jesucristo, para conjurar el mal o la enfermedad de los miembros de la familia.

El día de la confirmación, antes de llegar a la iglesia, los chapayekas se forman en dos filas, los padrinos se colocan al lado del iniciado, a quien persignarán con el rosario, kusim. El iniciado porta cinturón de pezuñas de venado o cerdo rijutiam, vestido de raso negro y cobija de lana, el kapita yo'owe lo persigna tres veces con una máscara o sewa (flor) perteneciente al padrino, y a partir de ese momento se le reconoce como chapayeka. Antes de salir a la iglesia tiene lugar el muhte o musukte, literalmente "bajar la cabeza", que consiste en una inclinación, genuflexión y hacer la señal de la kus frente a un altar o imagen.

Por último, se dirigen a la guardia, donde saludan de mano a todos los presentes $\mathrm{y}$, mientras esto sucede, portan la máscara que pertenece a su padrino sobre la nuca. El padre del iniciado tiene que llevar agua de horchata o cebada y capirotada para ofrecer a los fariseos, kabayum y cantoras.

La iniciación también puede ser forzada, pues si alguien está de curioso "lo agarran y lo confirman", y así, una vez efectuado el rito, el nuevo fariseo no podrá rehuir las obligaciones que tiene que cumplir con el grupo. Si, por el contrario, decide que ya no puede cumplir con la manda, debe organizar y pagar un pahko por tres años consecutivos y sólo así se dará por cumplido su compromiso. Esta solución, no obstante, es poco frecuente, dado lo elevado del gasto económico, por lo que la mayoría prefiere cumplir con la manda año tras año. Por lo general, el dltimo viernes de waehma ya no se realizan confirmaciones, y se da paso a la preparación de las cuatro jornadas de intensa actividad ritual que cubre la Semana Santa.

Domingo de Ramos, San Ramos o San Ramón marca el inicio de la semana mayor. La figura de Jesús sale en procesión, en conmemoración de su 
llegada a Jerusalén, después de un servicio en la iglesia, al cabo del cual se reparten hojas de mezquite entre la gente y se canta el Gloria Laus. La procesión señala el recorrido de la cruz, el conti vo'o, alrededor de la iglesia del poblado con las ramas de mezquite que son llevadas al centro del tebat desde ese día y que serán el escenario de la persecución y captura del "viejito" el jueves santo. 
Oficio de Tinieblas, Última Cena y Viernes Santo

\section{Tinieblah}

Al atardecer del miércoles santo, la gente de las comunidades yaquis se apresura a cumplir con los pendientes domésticos con el fin de dedicarse los días siguientes a la conmemoración de la captura, muerte y resurrección de Jesús. Ya sea que se trate de cumplir con su promesa, fungir como padrinos o colaborar en la cocina, durante estos días de culto los yoremes no trabajan y reducen al mínimo las labores cotidianas.

$\mathrm{Al}$ anochecer, las familias esperan que el maestro litúrgico reanude la conmemoración de la Semana Santa, interrumpida desde Domingo de Ramos, con el Oficio de Tinieblas o Tinieblah. Como todas las fiestas yaquis, Tinieblah comienza al morir el día. Alrededor de la once de la noche, el maehto y las kiyohteis disponen frente al altar el candelabro triangular de madera pintado de azul que sostiene cuarenta veladoras que serán encendidas a esa hora. El momento en que el total de las velas se ha consumido, es la señal que todos esperan para dar inicio.

El escenario de Tinieblah es el costado oriente del tebat, el conti vo'o y el interior de la iglesia. El altar principal está dedicado al santo patrono de cada pueblo, en el caso de la Loma de Guamúchil se trata de la Virgen de Guadalupe, del lado izquierdo la Dolorosa y a la derecha, el Nazareno ${ }^{5}$.

En los altares secundarios están dispuestas las figuras de San José, la Virgen María -en ocasiones las tres vírgenes o Marías - y las imágenes propias de la waehma, como un Ecce Homo conocido como Resurrección que encabezará las procesiones de Sábado de Gloria y Pascua. También están presentes, al igual que en la celebración de la Virgen del Camino a principios de julio, tres vírgenes o tres Marías, sólo que en esta ocasión se trata de la Dolorosa, Magdalena y Socorro. La indumentaria de estas tres imágenes, de veinte centímetros de altura, va cambiando de acuerdo al

5 Esta imagen representa a Jesús con túnica púrpura y corona de espinas, llevando la cruz, a quien se captura el jueves santo 
transcurso de las celebraciones, y junto con la kus, encabeza los contis. La cruz pintada de negro con la inscripción INRI recibe el nombre de Salvador Maehto cuando lleva a Jesús crucificado.

Al sonido de los tambores, ya reunidos al costado oriente de la iglesia, los fariseos se forman en dos filas: al frente las autoridades encabezadas por el Pilato y sus dos capitanes, de tambor y flauta. Le siguen los soldados mayores con el traje negro, después los enmascarados. La indumentaria de los chapayekas es variada y cada año se elige una diferente. Los de mayor jerarquía y conocedores de la liturgia portan el traje "clásico", que consiste en pantalón y camisa blancos parcialmente cubiertos por una cobija de lana a cuadros a manera de chaleco, cinturón de pezuñas de venado rijutiam, tenavaris con borlas rojas, $k u s$ al cuello y sewa o máscara de cuero que representa un hombre blanco de nariz recta, barbado, con grandes orejas pintadas con motivos florales y adornado con una corona o diadema. Otros llevan gabardinas o sacos de casimir y polainas con hebillas en sustitución de los tenavaris.

En 1996, los enmascarados más jovenes de la Loma de Guamúchil eligieron ataviarse como dos payasos, un pirata, un Memín pinguín, un punk con peinado al estilo taxi driver, un cholo y dos apaches. Los cabitos, por su baja jerarquía, van al final de la formación con un traje similar al de los soldados, pero con el rostro descubierto.

Se inician las actividades de tinieblah con un conti dirigido por la formación de fariseos, mientras los representantes del teopo ya'ura, maestro y cantoras, entonan alabanzas en el coro de la iglesia. A su término, el kohtumbre se alinea en dos filas a la entrada del templo para iniciar, así en el umbral, el avance de la oscuridad y la expiación sobre la luz y las flores, símbolos del trabajo ritual tekipanoa representativo de las fiestas del período ordinario.

El Oficio de Tinieblas se desarrolla en el lapso comprendido entre el conti y el momento en que se consume el total de las luces del candelabro de madera. A lo largo de estas más de dos horas, cada chapayeka, escoltado por dos soldados, debe recorrer la nave desde la entrada, donde se ubican los de mayor jerarquía, quienes le ordenan mímicamente agacharse al ras 
del suelo y aproximarse así hasta llegar al altar. En posición lateral, los enmascarados cruzan sus bastones y recorren arrastrándose a lo largo de la nave de la iglesia hasta que llegan a la luz, ahí se entrecruzan, hasta que reciben la orden de ponerse de pie. Esta actividad se repite tantos turnos como sea necesario hasta que se haya extinguido la luz de las velas. Durante esta secuencia sólo se escucha el entrechocar de las armas de madera, el tambor, el zapateado y, a la señal del Pilato, el sonido producido por los rijutiam.

Mientras permanecen formados esperando su turno, los chapayekas imitan los movimientos de un anciano o inválido y golpean levemente con su bastón los pies de los soldados, quienes reaccionan exageradamente brincando hacia atrás como si repeliesen un ataque. En determinados momentos, el Pilato ordena mímicamente alejar a los enmascarados con su espada de madera o con una serpiente de plástico que porta en la mano.

Alrededor de la 1:30 a.m., en el momento en que se extinguen las velas, también apagan la luz eléctrica de la iglesia sin bancas, y ya en completa oscuridad, la tropa de fariseos irrumpe hasta el altar para iniciar con la culminación de Tinieblah: los tres azotes en la espalda que cada uno de los presentes recibe por parte de su "padrino" es decir, por parte de una persona "de respeto", "un mayor".

Cada uno de los presentes hombres, mujeres, niños con o sin cargo, recibe tres latigazos o cintarazos en la espalda, mientras el castigado permanece hincado y el padrino hace la señal de la cruz sobre la espalda y procede a dar los golpes. Al ponerse de pie, el ahijado tiene que dar las gracias: Dios emchi ouhtesia.

Un joven chapayeka me dijo que se conmemora el sufrimiento de Cristo por los latigazos que recibió al inicio de la Pasión y su significado no es punitivo sino, en sus propios términos, una "quitada de pecados", una "purificación", esto es, una expiación.

Los fariseos son golpeados de manera particularmente fuerte, y de acuerdo con el testimonio de uno de ellos, antiguamente no sólo se propinaban tres golpes sino que el padrino continuaba golpeando hasta que el castigado 
indicara el momento en que ya no podía soportar más: "ahora los golpes son leves, antes eran de veras".

Cada miembro del kohtumbre conoce su lugar en la jerarquía y por ende quién es el indicado para ser su padrino: los soldados azotan a los enmascarados, quienes a su vez infringen los golpes a los cabitos.

Los fariseos, que forman un grupo compacto del cual sólo se separan para cumplir una orden, salen de la iglesia en su formación habitual hacia su guardia, montículo y hoguera al costado oriente de la iglesia. Antes de descansar y colocar sus armas en el montículo levantado ex profeso, las dos filas realizan cinco recorridos con cuatro cambios de paso.

Visto en conjunto, el ritual que tiene lugar en tinieblah recuerda sólo tangencialmente el modelo católico ${ }^{6}$ y la atención a sus movimientos indica, más allá de cualquier otra interpretación, un enunciado que afirma en términos espaciales, el avance de la oscuridad real e imaginaria (fariseos de negro) sobre la luz de la iglesia. Tal como ocurre el Sábado de Gloria, cuando la toma de la iglesia por el kohtumbre es contenida con las flores que arrojan los angelitos, en Tinieblas ya no hay flores ni luz, las velas se extinguen para dar paso a la expiación de la comunidad entera encabezada por los fariseos. Esta relación permite identificar a Tinieblah y Sábado de Gloria como contraparte de un mismo rito con cuatro días de duración, donde ambos se sitúan en los extremos: en tinieblah vence la oscuridad, el sábado, la luz y las sewam. El predominio del eje norte - sur con ritmo bipolar dentro - fuera es definitorio de ambas secuencias complementarias.

${ }^{6}$ Si bien es cierto que el modelo católico es reconocible en sus elementos más generales, para Muriel Painter (1986) y Rosamond Spicer la Semana Santa yaqui sigue los episodios que pueden encontrarse en cualquier misal. No obstante, habría que reconocer que están presentes de manera simultánea dos o más paradigmas alternativos. 
Última Cena y la correteada del viejito

Después de un breve descanso, las actividades del jueves santo se reanudan al amanecer con el servicio oficiado por el maestro litúrgico, al cabo del cual el kohtumbre encabeza el recorrido del conti vo'o a las seis de la mañana. Cabe señalar que la mayoría de las etnografías dedicadas a la Semana Santa yaqui confieren a las procesiones o conti, el carácter de ritos en sí mismos, como si éstas fueran el objeto privilegiado de la actividad ritual. La reconstrucción de las secuencias, me permite afirmar sin embargo, que los recorridos elípticos, si bien son importantes porque congregan a un mayor ndmero de participantes, sirven fundamentalmente como marcadores que indican el avance de la representación conmemorativa. Entre uno y otro conti se verifica un acontecimiento importante desde el punto de vista ritual.

A la mañana del jueves corresponde la secuencia conocida como el camino de mantas. Este día ya todos los fariseos, incluyendo los cabos, se colocan el luto que es un velo negro que cubre el rostro. En el centro de la iglesia permanece el Ecce $\mathrm{Homo}^{7}$ y frente a éste el patrono de los caballeros, el Santo Niño, ambas imágenes custodiadas por los Kabayum. El grupo de la iglesia - maestro, cantoras y temasti- permanece al costado oriente, mientras los fariseos forman con sus mantas un camino que va desde la entrada hasta el centro del altar.

Las ramas de álamo que adornan los altares de la iglesia son transportadas a la cruz del perdón situada al extremo del tebat, sitio que servirá de albergue al "viejito". El viejito es representado por un hombre joven de la comunidad que ha sido seleccionado desde el año anterior. La identificación del viejito con Jesús sorprende a Spicer, no obstante, de acuerdo con el testimonio recogido por los esposos Spicer en la voz del músico José María Casillas, a estas alturas de la waehma es claro que Jesús sea un anciano:

7 Imagen conocida como "Resurrección" durante el Sábado de Gloria y Domingo de Pascua. 
"Before the first Easter there were only Jews, no Yaquis or other people. The first man was born on Christmas in Belen which is up north somwhere. This first man, Jesús, was one week old when Holy Week (Lent) started; he was an angelito in his mother's arms. Each week Jesús was bigger. He could walk at three weeks; he had hair on his chest at five weeks; his hair was white at six weeks; and at seven weeks he was so old he could hardly walk and they seized him and killed him. Before Jesús was born there were no dances, no harps, no Pascolas. They were all in the ground and had to be gotten out. Jesús knew how to get them out and he did. He taught everybody these things and there have been fiestas ever since. Everyone before this time was dying, but when Jesús brought all these things and taught them, then they all lived and they came down to the Yaqui River. The Easter dances are about this time" 8

Mientras el kohtumbre permanece acampado en su guardia al costado oriental de la iglesia, los caballeros y las autoridades civiles y militares observan desde su enramada el transcurso de las ceremonias. Alrededor de las tres de la tarde el "viejito", junto con doce niños de 7 a 10 años de edad que representan a sus apóstoles, sale del templo para dirigirse a la enramada situada al oriente, en cuyo interior se encuentra colgado un cromo enmarcado de la Última Cena y una mesa con dos bancas. El viejito se sienta al centro, rodeado por sus doce apóstoles que llevan ramas de mezquite en la cabeza a la usanza romana. Desde el umbral de esta enramada y hasta la cocina, se colocan en fila quince varones adultos representantes de los kabayum y autoridades civiles y militares quienes son los encargados de transportar, de mano en mano, los doce diferentes platillos que se ofrecen a Jesús y sus apóstoles.

Los doce apóstoles comen hasta hartarse, mientras el viejito únicamente los observa, lo que alguno de los doce niños ya no puede comer, lo guarda para llevárselo en tortillas y bolsas de plástico. Chícharos, calabacitas, sopa de pasta, arroz, fideos, frijoles, atole, capirotada, nopales, chichiquelites, todo acompañado de tortillas. El alawasin es el encargado de recoger los platos sucios y llevarlos a la cocina.

\footnotetext{
${ }^{8}$ Edward H. and Rosamond B. Spicer field notes, 1936-37; R.B. Spicer 1939
} 
Al término de la comilona, los niños apóstoles son despojados de sus coronas de mezquite y se dirigen a la iglesia rodeando al viejito, al pie de la puerta principal, los chapayekas les arrebatan al viejito "a la fuerza" a sus apóstoles. Este episodio conocido como la "correteada" o persecución del viejito continúa después de dos contis. Jesús es perseguido hasta que se refugia en la cruz cubierta por las ramas que fueron transportadas desde Domingo de Ramos, atrás de la cual se encuentra una imagen de bulto del Nazareno. Una vez ahí, atrapado, quitan las ramas y ya aparece vestido de túnica blanca y deja su ropa de civil. Durante la correteada del Viejito las mujeres se avergüenzan de que vaya "desnudo", cuando en realidad lleva puesta la túnica. Los chapayekas colocan, tanto al viejito como a la imagen, una soga alrededor del cuello, como si fueran prisioneros.

Ahora que ya ha tenido lugar "la rendición de la llave de la iglesia", prosigue la procesión del Nazareno. A lo largo de su recorrido, el viejito lleva en la mano una rama de álamo con la cual golpea a cada uno de los chapayekas que durante la procesión avanzan en escalas de tres o cuatro metros. Cada uno de los chapayekas se pone a gatas para esperar los golpes del viejito. En las estaciones del viacrucis, el viejito se sienta sobre la espalda de cada uno de los enmascarados puestos en cuatro patas. En la séptima estación, dos mujeres que representan a la Verónica y su acompañante se aproximan para darle de beber. Tiene lugar otro conti $i^{9}$, a cuyo término un grupo de mujeres con ramas de álamo intenta defender al viejito de los chapayekas, con empujones, gritos y jalones. Los chapayekas se burlan del viejito imitando sus movimientos, pero en dirección contraria, hacia el sur, dando la espalda a la iglesia.

En la cruz del perdón los chapayekas colocan guajes y sombreros para recibir las limosnas para cubrir las necesidades del kohtumbre. Cada vez que reciben una, los chapayekas agitan el cinturón de pezuñas de venado y golpean con los bastones.

9 EI orden de la procesión es el siguiente: a los lados la formación de fariseos, al frente en línea: el crucifijo, el Nazareno y la Dolorosa seguidos por las autoridades. En medio mujeres y niños. 
Al término de este rito, el grupo de la iglesia vuelve a colocar el crucifijo al interior de la iglesia y el viejito se queda ya en poder de los fariseos. La imagen del Nazareno también está en la iglesia "presa", amarrada por dos sogas sostenidas de cada lado por un chapayeka. Como carceleros de la imagen, los dos enmascarados se burlan del Nazareno, mientras los rezos de las cantoras continúan en la entrada de la iglesia.

Posteriormente, tiene lugar la "puesta del hábito" de los niños menores de un año, prometidos por sus padres y acompañados de sus padrinos, en preparación para su "confirmación" el Sábado de Gloria. Esta es la única iniciación (rito de paso) que tiene lugar en el tiempo sacro de la Semana Santa. 


\section{Viernes Santo}

Este día se caracteriza por la creciente observancia de los tabúes referentes a la alimentación, el vestido y el trabajo. Estas prohibiciones alcanzan su clímax en el momento de la séptima procesión del viernes, que tiene lugar entre las 3:00 y las 5:00 p.m. A partir de esa hora, los cabos recorren vigilantes las calles sin pavimento de los pueblos yaquis, ordenando a las mujeres que se despojen de lazos y moños en el cabello, igualmente, inspeccionan la conducta de los niños y observan que ningún adulto trabaje, ande en bicicleta o pierda la compostura.

La primera de las procesiones o conti es a las seis de la mañana y sirve de señal para la ceremonia de "la cruz de pecho", que no es sino la bendición de los hombres y mujeres que fungen como padrinos y madrinas de los chapayekas. Al interior de la iglesia se forman de manera alternada padrinos y madrinas de los chapayekas, hombres y mujeres, con las manos entrelazadas y descalzos - quienes no deben llevar adornos ni peinadospara hacer la señal de la cruz acercando el pecho al suelo, tal como lo hicieron los chapayekas en Tinieblah.

La siguiente procesión es el momento de "sacar al viejito", quien en esta ocasión no es sino el Ecce Homo que había permanecido en poder del kohtumbre desde el día anterior. Esta imagen va al frente del conti junto con la Dolorosa, el Nazareno y el Crucifijo. Los angelitos, sus padrinos y miembros del teopo ya'ura permanecen desde este día al interior de la iglesia, en la parte cercana al altar que se distingue como "el cielo" y que será su "cuartel" desde el cual darán la batalla a los fariseos el Sábado de Gloria.

Cabe recordar que todos los recorridos circulares o conti se realizan en sentido antihorario, en dirección sur - este - norte - oeste; constituye la excepción a esta regla el conti que tiene verificativo alrededor de las ocho de la mañana del Sábado de Gloria, conocido como el "recorrido del Malhumor", que se realiza en sentido horario. 


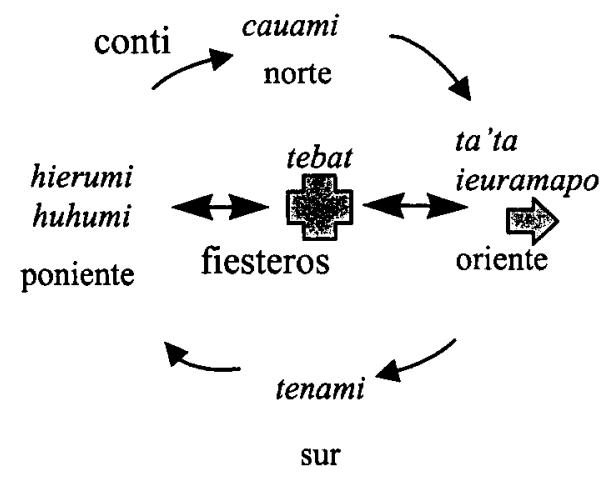

Las danzas - marcha de los fariseos acompañan cada una de las secuencias del ritual, tales como la Crucifixión y muerte de Cristo, en esta escena cuatro jóvenes ataviados con túnicas blancas, que juegan el papel de Nicodemo, depositan en la "urna" al Ecce Homo. La urna es un ataúd de madera pintada de blanco con tul y encaje blancos en los bordes, adornado con flores y dos palomas blancas de papel colocadas en los dos extremos superiores.

Al pie del ataúd son colocados floreros con flores blancas y rojas, dos cirios y palanganas de plástico para recibir las limosnas. Este es el momento en que las familias tienen la oportunidad de recordar a los parientes fallecidos a lo largo del año. Las flores y veladoras, que llegan a rodear completamente la urna al atardecer, están consagradas a los yoremes muertos a quienes se conmemora junto a Cristo. Las imágenes sagradas ya se encuentran cubiertas con mantos negros.

A las 20:00 horas tiene lugar otro conti, el más solemne de todos durante el cual se observa un orden estricto: 


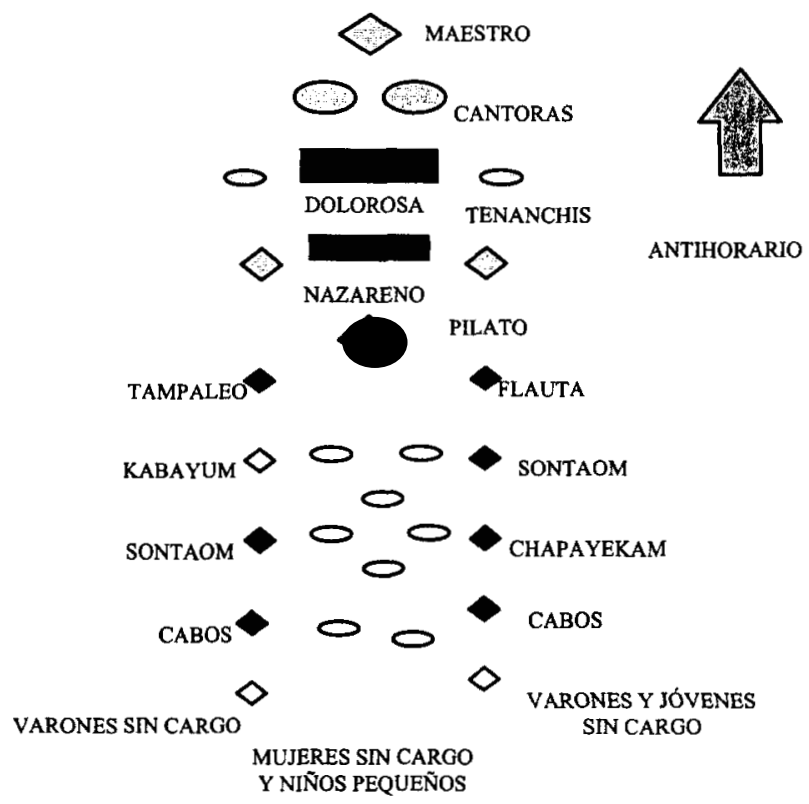

Al cabo de éste, las marchas de los fariseos continúan al lado derecho de la iglesia, preparándose para volver a irrumpir en la iglesia, corriendo y empujándose, en tres ocasiones hasta que logran ingresar. En el tebat, sólo se escucha el chocar de las espadas y puñales de madera. Las marchas y procesiones del kohtumbre siguen hasta el amanecer. 
Sábado de Gloria y Domingo de Resurrección

La "fiesta los chapayekas" marca el inicio de la jornada ritual del Sábado de Gloria. Este día "descansa el Viejito" y el nuevo protagonista es el Judas: se trata de un muñeco fabricado con paja vestido con ropas similares a las de cualquier varón de la región -yoreme o mestizo- camisa blanca, pantalón de color café, sombrero vaquero; en la mano izquierda sostiene unos chacos fabricados de cartón y en la derecha una radiograbadora igualmente simulada. En ambos brazos lleva atados listones de distintos colores. $\mathrm{Su}$ cara y cabeza están cubiertas por una máscara de chapayeka de las "clásicas", orejas grandes y corona. Para "despertarlo", los chapayekas interpretan, por primera vez en el período Cuaresmal, música de violín o de violín y guitarrón. Dos de ellos ejecutan "Las Mañanitas", al tiempo que los demás enmascarados marcan el ritmo chocando sus armas de madera.

Resulta sorprendente el ambiente festivo que reina este día, cuando se compara justo con lo ocurrido el día anterior: las jóvenes y niñas se ponen ropa de estreno y todos los asistentes se presentan aseados y peinados para "despedir al Malhumor".

Alrededor de las siete, tiene lugar el conti dedicado a los niños, quienes acompañados por sus padrinos y madrinas, hacen el recorrido junto con el Judas o Malhumor. El monigote pasea por el camino de la cruz montado en un burro escoltado por tres chapayekas como si lo llevaran preso, un chapayeka por detrás y los otros a los lados. Unicamente en esta ocasión la procesión se realiza en sentido horario, y por primera vez acompañada con sones de violín y guitarrón ejecutados por dos chapayekas. También es la primera ocasión, desde el jueves santo, que los kabayum marchan con sus lanzas apuntando hacia arriba.

A lo largo del recorrido los chapayekas simulan burlonamente las funciones de un sacerdote: dirigen incienso al Judas, consultan un misal y le rocían "agua bendita"10. Al término de la procesión, y ya colocado el Malhumor al

10 Dorothy M. Beals apunta:"The Judas procession with the figure riding backwards on an ass and the backward ritual recalls the Festum Stultorum (Feast of Fools) 
costado oeste de la cruz del perdón, cada uno entierra en el cuerpo del Judas, un cohete. El resultado es la imagen de un sacrificado con el tronco cubierto de flechas.

El Judas permanece así en el centro del tebat mientras los chapayekas, al este de la iglesia, forman un círculo y danzan al son del violín y guitarrón, obsequiando a los espectadores, en particular a los niños, dulces, canicas, huevos de confeti a cambio de unas monedas. Al momento de tener que abandonar al Judas simulan tristeza, dos de ellos tocan "Las Golondrinas" en señal de despedida, mientras los demás acompañan rítmicamente con el chocar de sus armas de madera.

La secuencia que sigue es la preparación de la batalla final entre las flores sewam y el kohtumbre, cuando al fin éste se despoja de sus máscaras. Para este efecto, ya se ha colocado el "cielo", que no es más que una sábana blanca a manera de cortina que divide en dos partes la nave de la iglesia. Esta cortina es literalmente, la puerta del cielo, el teweka loria, santo cielo que corresponde en gran medida al sewa ania, concepto en el que se reconoce el teopo ya'ura, el mundo de las flores y el río. El acceso a este mundo se abre el Sábado de Gloria, cuando el kohtumbre es vencido, hasta el día de la Santa Cruz, el tres de mayo. Desde el inicio de la waehma hasta la Asunción, las puertas de teweka están cerradas. Para alcanzar este ámbito, el mito refiere que es preciso atravesar un camino peligroso y lleno de piedras, lo que se dificulta aún más porque quienes llegan a él "andan descalzos": los muertos y los iniciados.

La parte adyacente al altar la ocupan las angelitas y los cabos con sus respectivos padrinos y madrinas. Arriba, en el coro de la iglesia, el maestro litúrgico y las cantoras entonan sus alabanzas y al pie de éste permanece la urna vacía. Del otro lado del "cielo", en el espacio abierto de la nave, se sitúa la mayor parte de los participantes, a los lados detrás de las columnas y cerca de las puertas, el público, dejando el corredor central para la entrada de los fariseos.

in which the Bishop of Fools rode backward on an ass and in which the ceremonial was as much reversed as possible" Some Notes on European Liturgical Drama and the Cahitan Semanas Santas, en Crumrine y Spicer en prensa. 
El kohtumbre avanza en formación compacta encabezados por el Pilato, y atrás en el siguiente orden: el tampaleo y flautero, los soldados y los chapayekas. A la izquierda del cielo ya están dispuestas las flores o sewam que consisten en hojas de álamo y papel picado de colores que los angelitos arrojarán a los fariseos, justo en el sitio en el que los pascolas y el venado harán su tekipanoa.

Los angelitos - con sus trajes de satín blanco con motivos dorados y blancos, alas de ángel y flores blancas en la cabeza- esperan del lado del "cielo", al tiempo que el Maso o Venado se prepara frotando la cornamenta de su tocado con las sewam.

La tropa de fariseos avanza marchando y hace tres "glorias" que consisten en tres intentos por entrar al cielo. En cada ocasión "se abren las puertas del cielo" y los ángeles arrojan "flores". Al cabo de la tercera gloria los fariseos "corren", a excepción del Pilato, acompañados por sus padrinos y madrinas, quienes colocan un paño en el brazo de su ahijado y junto con él se apresuran a quitarle la máscara, para arrojarla junto al Judas e intentar llegar a toda velocidad al "cielo". 


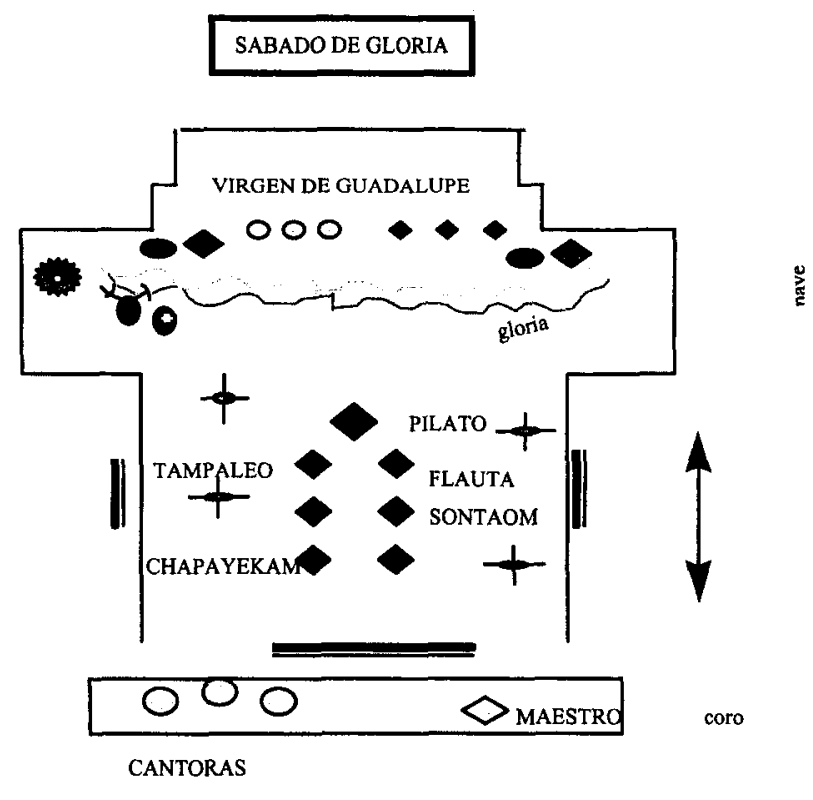

Al quitarse la máscara se cubren con un pañuelo, porque según ellos, "traen la cara sucia". Después salen otra vez en formación y se dirigen a su guardia. Al lado izquierdo del cielo los tres pascolas y un venado danzan acompañados por sus músicos. En ese momento hacen su aparición, por primera vez desde la Candelaria, los soldados de la virgen, la tropa de matachines y sus músicos. Al término de las glorias, Venado y Pascola irán a su enramada, al oriente del tebat, para bailar ahí toda la noche hasta el amanecer de Pascua. Ahora sí, se considera el inicio de la fiesta.

Al poniente del tebat, la hoguera formada con el cuerpo del Judas y sus cohetes clavados en el pecho, crece alimentada por los sombreros, máscaras, bastones, espadas y cuchillos característicos del kohtumbre. El Judas permanece en el tebat hasta las 13:00 horas, cuando el alawasin le prende fuego y explota en mil sonidos. 


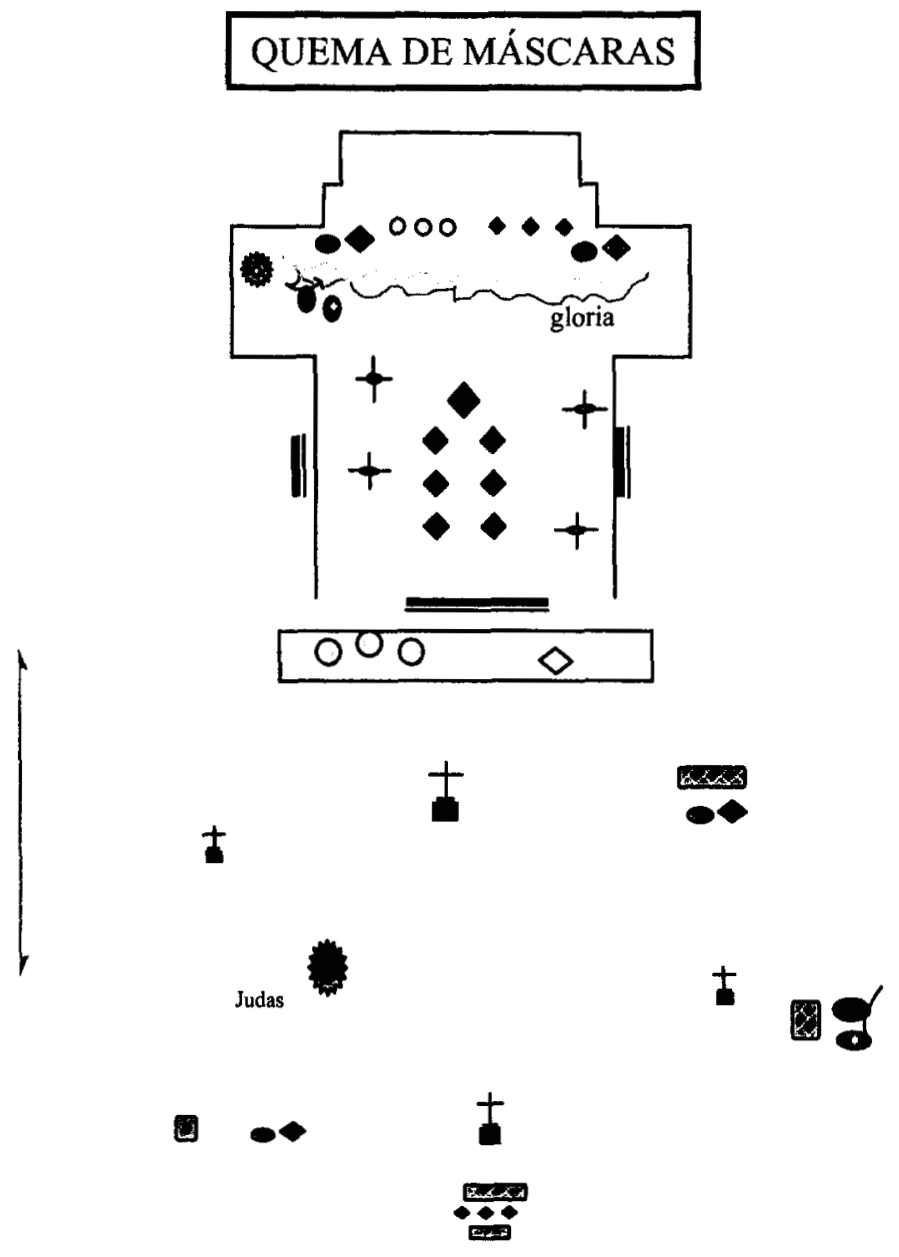

No todas las máscaras de chapayekas son arrojadas al fuego, dos de ellas que tengan "corona" se conservan, con el objeto de usarlas en caso de que algún miembro de la cofradía muera en el transcurso del año, la otra servirá para ser usada en la efigie del malhumor del próximo ciclo. 
Después de dar las gracias a sus padrinos y madrinas, los fariseos se retiran a su guardia. Al atardecer reina la calma y todos vuelven a la vida cotidiana que se interrumpe por el regreso de los fariseos, ya sin máscara, pero con una santa borrachera.

El domingo de Pascua prosiguen hasta el mediodía las danzas de pascola y venado. La participación de los Matachines cesa la madrugada del Domingo con la "corrida de la Virgen", mientras las familias se reincorporan a las actividades cotidianas esperando que se presenten los vientos del oeste. Por lo general en estos días se producen tolvaneras y los yoremes lo toman como buena señal para el período de lluvias que se anuncia.

Cristo resucitado es el responsable, en la tradición oral yaqui, de mandar los vientos del oeste durante la waehma. En Pascua, no obstante, Jesús no resucita como hombre, sino como un recién nacido cuya vida se inicia esta fecha y transcurre - debido a lo acelerado de su crecimiento- a lo largo de un año. 


\section{TRANSPOSICIONES ESTACIONALES: INCESTO IMAGINARIO}

En este apartado me interesa reconstruir el campo semántico de los fenómenos meteorológicos asociados a la waehma, a partir de los mitos y fragmentos de éstos, es decir, las creencias. Este acervo se encuentra en la tradición oral yaqui, conocida desde la década de los cuarenta por Spicer (1940b), Fabila (1978), Giddings (1959) y Painter (1986).

La waehma llega a su fin con las tolvaneras que anuncian el término de los vientos del oeste. Este fenómeno, junto con el de las tormentas acompañadas de rayos y truenos, los meteoros y estrellas fugaces, forma parte de un sistema de creencias más extendido, que asocia los funerales y la muerte con los fenómenos meteorológicos mencionados.

En dichos mitos está presente la idea de que si, en los funerales de una persona tiene lugar una fuerte tormenta con rayos y truenos, es una señal de que el difunto cometió incesto. Esta creencia, documentada tanto entre los yaquis de Sonora (Olavarría 1995) como de Arizona (Painter 1986), no puede ser entendida más que haciendo un recorrido a través de un conjunto de ideas concernientes al fenómeno meteorológico de los rayos y truenos' ${ }^{1}$.

Las fuertes tormentas son por demás inusuales en el territorio semidesértico yaqui y llama la atención su carácter aparentemente inconexo con el ciclo vital y ritual. Paralelamente, la alusión al incesto nos lleva a investigar alrededor de los mitos que hacen referencia tanto a la Prohibición como a los fenómenos meteorológicos mencionados.

En este sentido, he analizado mitos que hacen referencia a personajes como el rayo, el trueno, Yuku el amo de la lluvia y por otro lado a Suawaka el meteoro o estrella fugaz, asociado a su vez a San Miguel (Olavarría 1989):

1 Hay registros de creencias afines entre los tepehuanes del norte, grupo de la misma familia lingüística: "Cuando son compadres y hacen la unión libre, se convierten en víboras, esto es, por no tenerse respeto, para que no suceda esto hay que respetarse, se hacen compadre" (Herrera Quiñones, Jesús Emigdio, Filosofia Odami, Programa Cultural de las Fronteras, 1981). 
"En tiempos antiguos, había serpientes con siete cabezas. Habitaban al nordeste de Guaymas cerca de la colina que tiene dos puntas, llamada Takalaim. También habitaban en otra colina río abajo cerca de la playa, llamada So'ori. En aquellos días la gente decía que si un yaqui se casaba con un pariente, se convertiría en serpiente. Empezaría como un gusanito en el monte y al cabo de un año ya le habría crecido una cabeza. A los dos años, tendría dos y a los tres años, tres. Y así cada año, le saldria una nueva cabeza hasta tener siete. Entonces estaría lista para salir. Cuando estas serpientes salen, hay vientos terribles e inundaciones. Suawaka está desde arriba observándolas. Sabe que salen cada siete años y que primero aparece la mitad de la cabeza. Entonces Suawaka les lanza un arpón de fuego. Esta es la estrella fugaz que vemos en la noche. Suawaka apresa a la serpiente que mató y la lleva con su suegra, su suegro y su esposa. El suegro es Yuku, dios del trueno y del relámpago. La esposa de Yuku es la lluvia. Todos ellos se alimentan de estas serpientes. Cada siete años, Suawaka baja a Takalaim, y a los siguientes siete va a So'ori. Para que Yuku y su familia tengan suficiente carne. Pero si Suawaka no desciende cuando una serpiente sale de la colina, hay mucho viento y lluvia." (Giddings 1959:56, traducción mía)

Puede decirse que si en un funeral cae una fuerte tormenta, es indicio de que Suawaka y su familia están ansiosos de alimento y por ello envían señales como las tormentas, rayos y truenos.

La asociación de las fuertes lluvias con los personajes incestuosos no está completa si no se toma en cuenta la importancia del elemento acuático, del viento $\mathrm{y}$ de los cerros o colinas que, tal como afirma la tradición mesoamericana, son consideradas como recipientes de agua. En otro relato, también recopilado por Giddings (1959:67), es descrita una serpiente gigantesca conocida como kurues, homófono de arco iris, con una cruz kus en la frente que se alimenta de animales marinos, pero también de ganado, cabras y hasta gente; a quienes inhala con su fuerte respiración. $\mathrm{Al}$ exhalar produce ventarrones y se cuenta que esta serpiente solía ser un maehto llamado Ascencio que "hacía cosas malas" y que cuando lo pusieron en la tumba, ésta se hundió, el cielo se nubló y del agujero salió un rugido como de león. Un cura que hablaba yaqui le ordenó irse a un lugar "donde no hubiera cristianos" y el animal se abrió camino por debajo de la tierra y la gente rezó para que el 
monstruo no se quedara en el pueblo. Así, esta serpiente llegó hasta el cerro de Nohme a vivir en el agua dentro de él.

La referencia a esta serpiente y la de siete cabezas no es exclusiva de este pueblo, tanto al norte como al sur de la región yaqui, etnógrafos como Zingg y Parsons reportan asociaciones similares y mitos pápago, pueblo, cora y tepehuán hacen referencia a un monstruo como el de la colina de Nohme.

Este monstruo - presente en numerosas tradiciones como el ofidico que se enfrenta al personaje de alta jerarquía - se asocia con el descrito por San Juan en 12.3 y ss. Apocalipsis:

"Y se vio otro signo en el cielo, y era un gran Dragón de fuego, con siete cabezas y diez cuernos, y en las cabezas siete coronas, y su cola barrió la tercera parte de las estrellas del cielo, y las echó por tierra. Y el Dragón se puso delante de la Mujer que quería parir, para comerse a su hijo cuando lo pariera. (...)

$\mathrm{Y}$ hubo un combate en el cielo, combatiendo Miguel y sus ángeles contra el Dragón. Y combatió el Dragón, junto con sus ángeles, pero no vencieron ni quedó lugar para ellos en el cielo. $Y$ fue arrojado el gran Dragón, la antigua serpiente que se llama Diablo; y el Satanás, el que engaña a todo el mundo, fue arrojado por tierra y sus ángeles fueron arrojados con él. (...)

Y la serpiente echó agua por su boca, tras de la Mujer, como un río, para arrastrarla en la corriente. Y la tierra ayudó a la Mujer; abrió la tierra su boca y se bebió el río que había echado por su boca el Dragón. Y se encolerizó el Dragón contra la Mujer, y se fue a hacer guerra contra los demás de su descendencia, los que observan los mandatos de Dios y tienen el testimonio de Jesús. Y se quedó en la orilla del mar."

Este pasaje también aclara por qué San Miguel Arcángel y no otro -quien entre los yaquis personifica al meteoro- es quien aparece cuando tienen lugar los ritos de muerte. Santiago de la Vorágine describe al arcángel:

"Él será, asegura Daniel, quien, cuando el Anticristo venga a la tierra, aparecerá entre los hombres para defenderlos y protegerlos; él fue el que luchó contra el dragón y sus secuaces, los arrojó del cielo y obtuvo 
sobre ellos una imponente victoria (...); él es igualmente el que al fallecer los fieles se hace cargo de sus almas y las introduce en el paraíso glorioso." (La leyenda dorada p.621, subrayado mío)

Si San Gabriel está presente durante la Anunciación (nacimiento), San Miguel se presenta con su balanza en el momento de la muerte y en el Juicio Final será quien mostrará ante el tribunal la Cruz, los clavos, la lanza y la corona de espinas.

Un ejemplo del centro de México que ilustra el proceso en el que San Miguel se asocia a la muerte, se encuentra en la transcripción fonética del nombre de San Miguel en Códices coloniales. En el Códice Kingsborough el tlacuilo (escribiente tradicional indígena) transcribió fonéticamente el nombre Miguel de dos maneras diferentes. Por el dibujo de dos glifos tradicionales: la flecha mitl, y el frijol negro, etl, que se mezclan para producir los sonidos "mi-e" o "mi-etl"; o pictográficamente por el dibujo de un solo glifo tradicional micquetl "bulto de muerto", el cadáver.

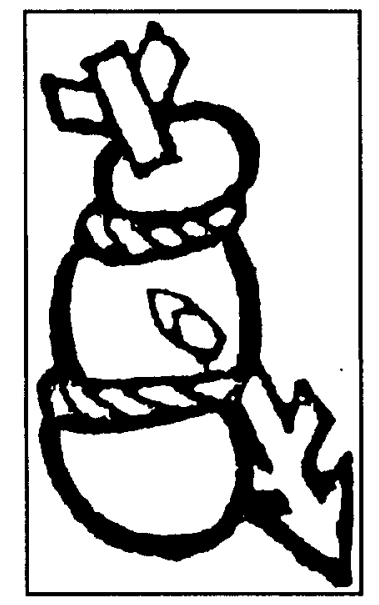

Tomado de lámina 3.9 fig. 7 en Galarza 1979 
Por su parte, el tlacuilo del Códice Santa Anita Zacatlalmanco, para transcribir fonéticamente el nombre Miguel, dibujó el glifo tradicional micquetl al cual añadió un elemento tomado de la iconografia cristiana, un ala del arcángel San Miguel (Galarza 1979:60)

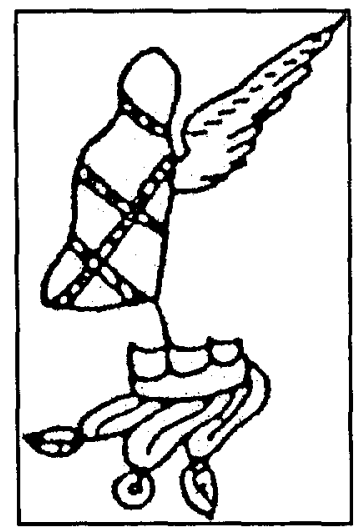

Tomado de lámina 4.2 fig. s en Galarza 1979

Los elementos de la tradición judeocristiana están presentes, pero dispuestos en un orden diferente, en el que su significado se trastoca, reformula o permanece. San Miguel - Suawaka - Meteoro aparece como aliado de la serpiente - Dragón. La asociación del monstruo ofídico con el elemento acuático está presente en el Apocalipsis, pero se refuerza con la noción mesoamericana de su refugio acuático dentro de una montaña.

Así, la posición sui generis con respecto a la religiosidad se presenta tanto en su relación con elementos del catolicismo jesuita como con las tradiciones prehispánicas mesoamericanas. Una muestra de lo anterior es la correspondencia entre la Virgen María con Itom Aye (Nuestra Madre) relacionada con la luna, Jesucristo con Itom Achai, Jesús, Lios, Achai O'ola (Nuestro Padre) - distintos a Jesús el curandero yaqui y héroe cultural también llamado Sanador, Maehto, Hitebi- y la preeminencia de otras figuras como la Virgen de Guadalupe, San José, la Santísima Trinidad y los santos patronos de cada pueblo.

La necesidad de variados conjuntos de creencias y prácticas queda de manifiesto tanto en los mitos como en el ritual. El origen de los propios 
yoremes está sancionado por la aceptación de éstos hacia el bautizo y la evangelización, mientras que sus antepasados míticos - los surem- al no reconocer la llegada de los blancos con la evangelización y el bautizo, quedaron condenados a la condición infrahumana de animales marinos 0 , en otra tradición, de hormigas y "pequeños animalitos del monte" que habitan el yoania (Olavarría 1989).

Sobre los surem sabemos que son un pueblo de pocos habitantes, con una estatura de tres pies de alto, que se alimentan de plantas silvestres como las espinacas y ciertas clases de lagartijas y conejos, no usan ropa sino sólo taparrabos, no se casan ni bautizan a sus hijos, no conocen la muerte y nunca enferman, con cada luna nueva se renuevan y viven una vida nómada en un mundo unitario, en el cual el hombre y los animales, insectos, flores y el mundo entero "comparten una vida psíquica en común" (Beals 1945:190).

El mito fundador del árbol o de la vara parlante se refiere a un tiempo anterior a la llegada de los españoles, en el que tuvo que encontrarse un intérprete capaz de entender el sonido emitido por el árbol o la vara parlantes, el mediador es una mujer, a menudo joven, que recibe diversos nombres y en ocasiones es gemela. La disyunción descrita en el relato es definitiva: por un lado los bautizados, bato'im, aquellos que aceptaron y absorbieron en sus vidas el catolicismo del siglo XVII encarnado en los misioneros jesuitas; y por el otro lado aquéllos que rehusaron ser bautizados, los surem quienes huyeron para preservar el yoania, la relación aborigen con el mundo. La relación entre estos dos polos recíprocos es compleja y constituye la base para el entendimiento de la visión del mundo yoreme.

El yoania está presente hoy día, aún oculto, pero concurre con el mundo visible y tangible de los hombres. Sólo muestra sus secretos y dones a quienes poseen atributos especiales para recibirlo. Puede aparecer en forma de visiones en lugares silvestres y alejados del desierto o las cuevas. También puede llegarse a él a través de los sueños. La serpiente forma parte de los sueños propios del yoania, siempre está al principio o al fin de ellos y los danzantes de pascola a menudo sueñan con las bakot hiawai, que son los sones que hacen referencia al reptil que se ejecutan al amanecer de la víspera de las fiestas. 
En sí mismo el concepto yoania encierra una concepción binaria en la que los cuatro elementos que componen la visión del mundo se reducen a un par. El tenku ania es el orden en que tienen lugar los sueños de los pascolas y venados, distinto al tu'i tenkuim asociado a las mandas y promesas de los iniciados en el teopo ya'ura. El sewa ania o "mundo flor" es el lugar del primer venado silvestre y del mundo natural en general. El tuka ania es el mundo de la noche y los sueños, y el huya ania que se relaciona con la noción de "monte", lugar de los yaquis broncos, los vaqueros y el choni. El yoania y el tuka ania están asociados como par frente al sewa y huya ania.

Aunque los surem pertenecen al yoania y puede decirse que éste fue el hogar precristiano de los yaquis, en el vocabulario Dios y el yoania aparecen como ámbitos separados, pero no contrapuestos, entre los cuales reina una especie de paralelismo. Esta aparente ambivalencia es uno de los puntos centrales de la visión del mundo yaqui, ya que no sería difícil marcar una separación entre, por un lado, surem, yoania, religión prehispánica y por el otro, yaquis, mundo empírico y catolicismo; sin embargo para los yaquis el catolicismo ha estado presente aún antes de la llegada de Cristo, aún más, Jesús era un yaqui, un curandero que se dio a la tarea de crear los marcadores temporales de la vida yaqui: las fiestas, así como sus componentes imprescindibles, las danzas.

Jesús aparece en la mitología como un héroe cultural yaqui que funda las danzas de Pascola, Venado y Coyote, y la Virgen funda la danza de los Matachines, la cual, más que una danza, es una forma de oración (comunicación) que permite la obtención de indulgencia. Esta relación entre Jesús y María tiene su correlato ritual en todas las fiestas yoremes que se realizan fuera de la Cuaresma y Semana Santa.

Las danzas de Pascola, Venado y Coyote, asociadas a Jesús no sólo constituyen, como afirman numerosos autores, una imitación o referencia a esos animales sino que fueron creadas por Dios "como un regalo (don) que nos permite servir a Él en las ceremonias". Por su lado, las danzas de Pascola y Venado están fuertemente asociadas al concepto de yoania.

La danza de matachines asocia, por otra parte, el color rojo y las flores que forman parte de su parafernalia con la sangre de Cristo: 


\begin{abstract}
"Cuando la lanza atravesó el costado de Jesús en la cruz, las gotas de sangre que cayeron se convirtieron en flores. Por esta razón las flores son un arma especial contra el mal durante todo el año y en el período de Cuaresma no hay flores durante siete semanas, porque no hay matachines. Los fariseos temen a las flores, pues se cree que María creó su ejército de matachines a la muerte de Cristo, quienes junto con los doce apóstoles y los amigos de Jesús, pelearon contra los fariseos. Por eso la música de los matachines se relaciona con la lucha batalla sonim".
\end{abstract}

Esta referencia mítica explica la exclusión de las danzas de Matachines y Venado durante la Cuaresma, podríamos afirmar que existe una oposición ritual entre matachines/fariseos y que se expresa en el hecho de que los fariseos son derrotados el Sábado de Gloria, cuando les son arrojadas flores. Así, este ejército de enmascarados identificado con la oscuridad, también está asociado a la categoría de lo bajo. De manera constante, los miembros del kohtumbre golpean sus pies con los bastones, andan descalzos y se arrastran como serpientes. El simbolismo asociado a la categoría de lo bajo también está presente en los ritos de paso individuales y en particular los funerales, ya que tanto los neófitos como los difuntos sólo pueden usar huaraches de tres puntadas amarrados a la usanza yaqui.

Es el contexto de los funerales y la muerte, en el que se sitúa preferentemente el campo semántico de las tormentas, rayos y truenos; por lo que trataremos de reconstruirlo con precisión. El funeral yaqui es un rito que presenta dos fases, el que tiene lugar en los días subsiguientes a la defunción y el que se realiza al cabo de un año solar del deceso. Esto es, el funeral / cabo de año representan una unidad, una fiesta única, puesto que tiene el mismo objetivo: marcar el paso a la muerte, que se cumple en dos momentos, instaurando un ciclo anual que corresponde a un año solar.

Cuando acaece la muerte de un yoreme se notifica al maestro litúrgico, y se le pide que junto con las cantoras acompañe a la familia en la ceremonia, entre todos acuerdan el mejor momento para iniciar. Desde el primer momento se mantiene a los parientes alejados del difunto al encargar a los padrinos de muerte, muka paínos, todos los preparativos de la ceremonia. Ellos se harán cargo del cuerpo y de los gastos que origine el rito. 
Los padrinos de muerte son cuatro hombres y cuatro mujeres, la primera opción es acudir con los padrinos de bautizo del difunto, pero en caso de ya haber fallecido se llamará a alguno de los hijos mayores de los padrinos y, en última instancia, a un hermano o hermana de los mismos. Cuando fallece un varón se asignan cuatro padrinos, quienes deben buscar a su respectiva compañera, y si se trata de una mujer se elige, en primera instancia, a las madrinas, quienes a su vez buscarán quien las acompañe. Suele suceder que un individuo en agonía escoja él mismo a sus padrinos. Por lo general se elige a personas de edad avanzada, casi nunca se designan jóvenes.

La primera actividad consiste en recaudar los fondos para el funeral, posteriormente, tal como acontece en todas las fiestas del tiempo ordinario o pahko, se disponen a levantar una enramada de carrizo frente a la casa del difunto, amortajan el cuerpo y lo colocan en un catre frente a la enramada.

Al igual que el resto de los pahko, el día ritual comienza al atardecer; para entonces al interior de la casa las mujeres de la familia cocinan el guacavaqui ${ }^{2}$, tortillas de harina de trigo y grandes ollas de café. Se convoca a los miembros del teopo ya'ura: maestro, cantoras, kiyohteis, tenanchis y matachines llegan a la enramada portando en andas imágenes de la Virgen, dando inicio así propiamente al funeral, también llamado "fiesta". Esta denominación llama la atención de la población mestiza quienes comentan, no sin ironía, que los yoremes necesitan morirse para que les hagan un festejo. Una vez que se ha colocado la imagen de la Virgen en el altar el maestro, las cantoras, padrinos y asistentes oran y cantan alabanzas. En este momento los padrinos se colocan alrededor del cuello un listón negro denominado "luto" y cada uno de los asistentes recibe una vela encendida.

Durante los nueve primeros días de duelo, los familiares del difunto deben observar una serie de prohibiciones, tales ritos negativos son análogos a aquéllos observados en la waehma y Semana Santa. En el plano alimenticio, consisten en la restricción de ingerir pescado, cerdo, leche, huevo, queso, papas y alimentos dulces; tampoco deben bañarse por un lapso de tres días, fumar, beber alcohol y trabajar. Además el cónyuge superviviente debe someterse a abstinencia sexual por lapso de un año o evitar volver a casarse en este lapso de tiempo, de lo contrario puede enfermar e incluso morir a causa

${ }^{2}$ Comida ritual que consiste en un cocido de res con garbanzo o frijol y verduras. 
de la violación de esta prohibición. A lo largo de los preparativos y el entierro, los parientes del difunto no deben ver ni tocar el cadáver, pues existe la creencia de que los muertos "llaman a los familiares o se los llevan".

Los padrinos permanecerán en velación y la preparación del cadáver estará a cargo de ellos, quienes harán unas motas de algodón ligeramente quemado, estas motas se colocan sobre el cadáver cruzadas en el torso y cintura, también se manda confeccionar un par de huaraches de tres puntadas con el cuero de la vaca sacrificada para la comida durante los días de duelo y con ellos se calzará al difunto. Las motas de algodón serán abiertas durante la ceremonia religiosa por el maestro litúrgico. De acuerdo con la exégesis, el algodón quemado representa al mismo tiempo la impureza, y el blanco de su interior, la cualidad contraria.

Cada pareja de padrinos porta un rosario, con el cual hace la señal de la cruz en la mano del cadáver e igualmente hacen la señal de la cruz con una cinta, en cuyo extremo pende una flor blanca de algodón en caso de que el difunto haya sido casado o una mota de estambre si era soltero. En ese momento los padrinos proceden a dar, cada uno, dos nuevos nombres a su ahijado "como si lo bautizaran", tales nombres pueden ser los de los propios padrinos u otros de su agrado. Así, al cabo de este ritual el difunto tendrá dieciséis nombres más de los que llevaba en vida. Los cuerpos de aquéllos que en vida ocupaban un cargo son amortajados con la indumentaria y parafernalia propia de su naturaleza.

Posteriormente se sirve la comida para todos los presentes. A los padrinos se les sirve una comida especial consistente en cocoivaqui y atole, después de lo cual regresan a velar el cuerpo durante toda la noche. La velación se prolonga hasta el amanecer, los matachines acompañan con su oración dancística los rezos orales del maestro y los padrinos. Se reparten entre los presentes tantas velas como sea necesario hasta que, al alba, los padrinos toman un descanso en los petates ordenados junto a la enramada.

El grupo encabezado por los Matachines y seguido por el maestro y los padrinos, sale rumbo al cementerio portando las imágenes de la Virgen. $\mathrm{Al}$ salir de la enramada, giran el cadáver dándole leves sacudidas haciendo la señal de la cruz, es decir, en dirección a los cuatro puntos cardinales. Al centro del poblado, hacen una parada frente a la cruz del perdón y al llegar al 
panteón, el Maestro yohue y tres matachines salen a recibirlos, mientras al interior de la iglesia se oyen las alabanzas que entonan las cantoras. Ya en el cementerio los matachines dan cuatro vueltas bailando alrededor de la fosa y son seguidos por los asistentes y los padrinos que portan el cadáver en un catre; hasta ese momento se deposita el cuerpo en el ataúd y se vuelve a sacudir levemente el cadáver en dirección a los cuatro puntos, haciendo cinéticamente una cruz. Al momento del descenso los dolientes se retiran, pues existe la creencia de que de lo contrario el difunto puede "llevarse a alguien", es decir que alguien más morirá.

Cuando el ataúd queda cubierto con tierra, clavan en el mismo sitio una cruz de madera pintada de azul y un carrizo. El uso del ataúd, que normalmente es de madera, es una costumbre relativamente reciente, ya que son obligados por las autoridades sanitarias a emplearlos; de acuerdo con la tradición, los yoremes muertos deben ser enterrados envueltos en petates.

El novenario se efectúa en casa del difunto y consiste en el rezo de un rosario por nueve tardes. Al noveno día se realiza un ritual muy parecido al funeral, con la diferencia de que el cuerpo no se encuentra más. Este día, no obstante, no termina la tarea de los padrinos, sino que al cumplirse un año del fallecimiento tiene lugar el "cabo de año". 


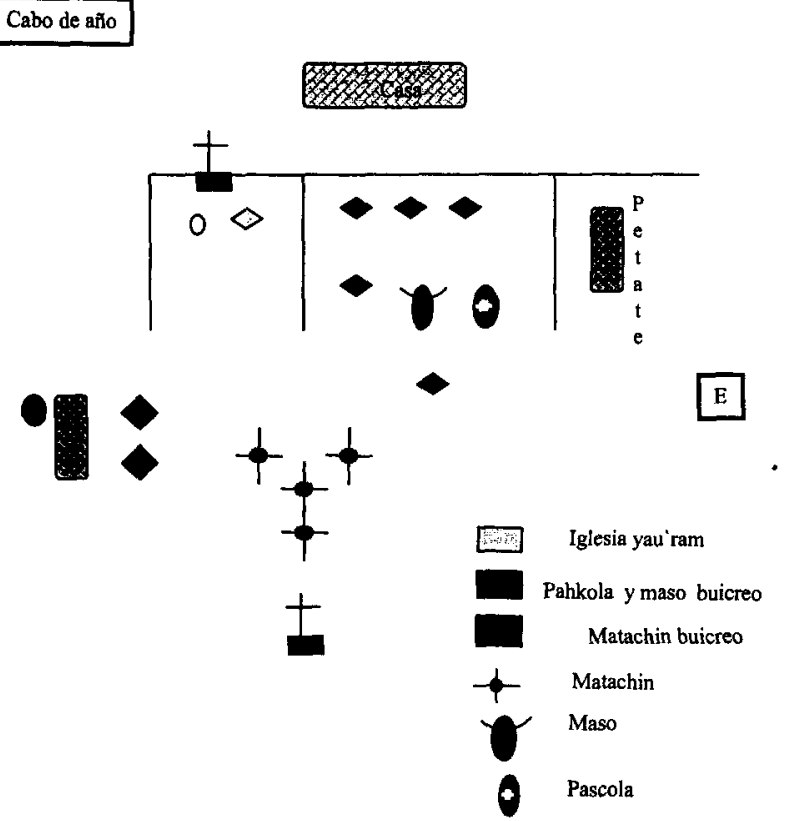

El cabo de año se realiza bajo el mismo patrón que el ritual mortuorio, pero en esta ocasión, además de la danza de Matachines, estarán presentes danzantes de Venado y cuatro pascolas, quienes ejecutarán sus danzas durante toda la noche. Salta a la vista el hecho de que este festejo es de mayor relevancia que el acontecido el día del deceso, hay ocasiones en que dura dos días consecutivos, al término de los cuales los danzantes de Matachín bailan sones que únicamente se realizan en esa ocasión. La cacería del Venado tiene lugar cuando el finado ocupó en vida un cargo importante en la jerarquía tradicional. En el juego previo a la muerte del Venado los padrinos cuidan y ocultan al venado de los cuatro pascolas que lo persiguen para cazarlo. Existe la creencia de que si el venado muere, el alma del difunto se va con él al cielo, pero de suceder lo contrario el alma se irá a vagar por al monte. Cabe decir que la cacería del Venado tiene un sentido lúdico importante, hay bromas y risas cuando los pascolas tratan de atrapar al venado y cuando lo logran, lo llevan a la enramada y simulan desollarlo. Asimismo, en ocasiones especiales, los matachines realizan una danza que se denomina trenzado, que consiste en entrelazar cintas de colores a un poste con una paloma y flores de papel en lo 
alto. Al entrelazar las cintas la paloma desciende por el alma y al soltarlas la paloma levanta el vuelo llevándosela.

Si el muerto es un infante, los padrinos de pila se lo llevan a su casa para velarlo, lo visten de blanco con flores de papel y lo llaman "angelito". Se les da sepultura de la misma manera que a los adultos pero sin el luto, ya que no hay motivo de pena pues creen que se van al cielo.

Varios signos ponen de manifiesto la relación que existe entre el ritual de Semana Santa con los ritos que se llevan a cabo durante el funeral - cabo de año. Están presentes en ambos la serie de prohibiciones alimenticias, sexuales y de otros tipos, la presencia de padrinazgos, el simbolismo alrededor de la permanencia de lo bajo, presente en la ausencia de calzado, la dificultad para caminar erguido y la alusión a las serpientes. La evocación de los difuntos alrededor de la urna que tiene lugar el Viernes Santo es confirmación de que en el orden de los símbolos, la conmemoración de la muerte de Jesús y la muerte individual ocupan lugares simétricos.

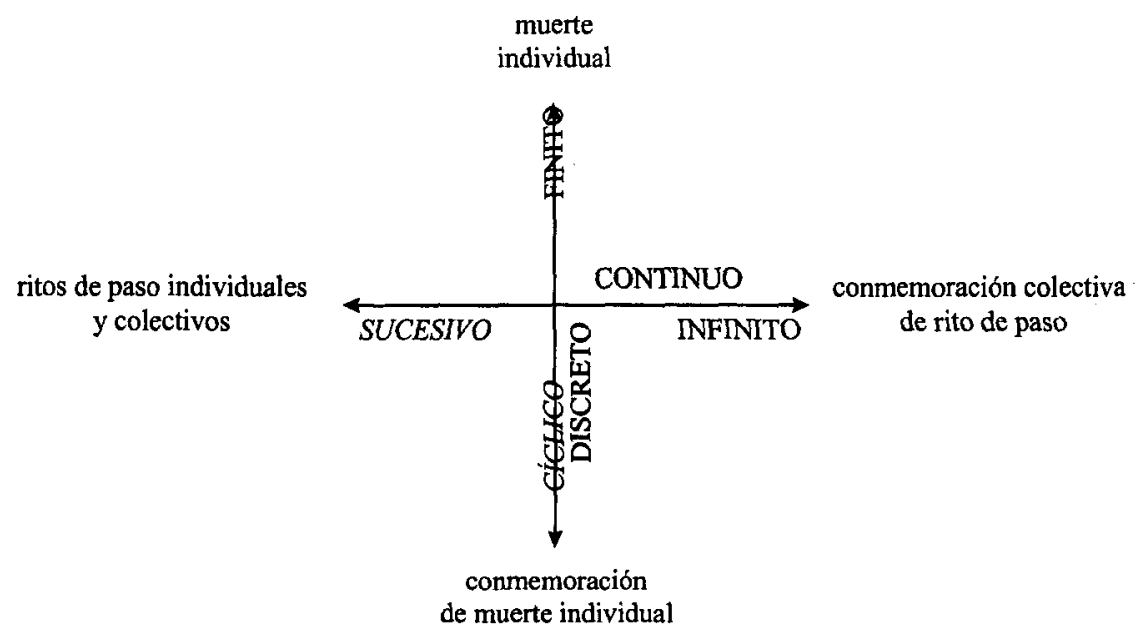


De lo anterior se desprende la noción de un principio de clasificación que alcanza distintos niveles y que se manifiesta en primer término en la oposición entre temporada de secas y de lluvias, relacionadas respectivamente con el culto a Jesús y a la Virgen. En el calendario ritual dicha clasificación queda expresada en la distinción tiempo ordinario / Cuaresma, la cual establece que los ritos concernientes al ciclo vital es decir, los ritos de paso, sólo se realizan en el tiempo ordinario - lluvia, Virgen, vida--y para el período de Cuaresma se deja lo relacionado con Jesús, la muerte y la sequía.

La intrusión que la muerte individual produce en el tiempo ordinario se resuelve imponiendo a los deudos el luto y los tabúes alimenticios y corporales propios del kohtumbre y de la Cuaresma y Semana Santa. Así, la presencia de prohibiciones similares durante la Cuaresma y los ritos funerarios tienen su sustento en la noción de muerte, sequía y luto que permea a ambos ritos. Sin embargo, el ritmo impuesto por el ciclo ritual - vital obliga a hacer alusión - al interior mismo del rito de muerte- al nacimiento y a la vida. Basta recordar que una de las tareas de los padrinos de muerte es el de poner una serie de nombres al difunto "como si lo bautizaran", es decir, como si en ese momento volviera a nacer.

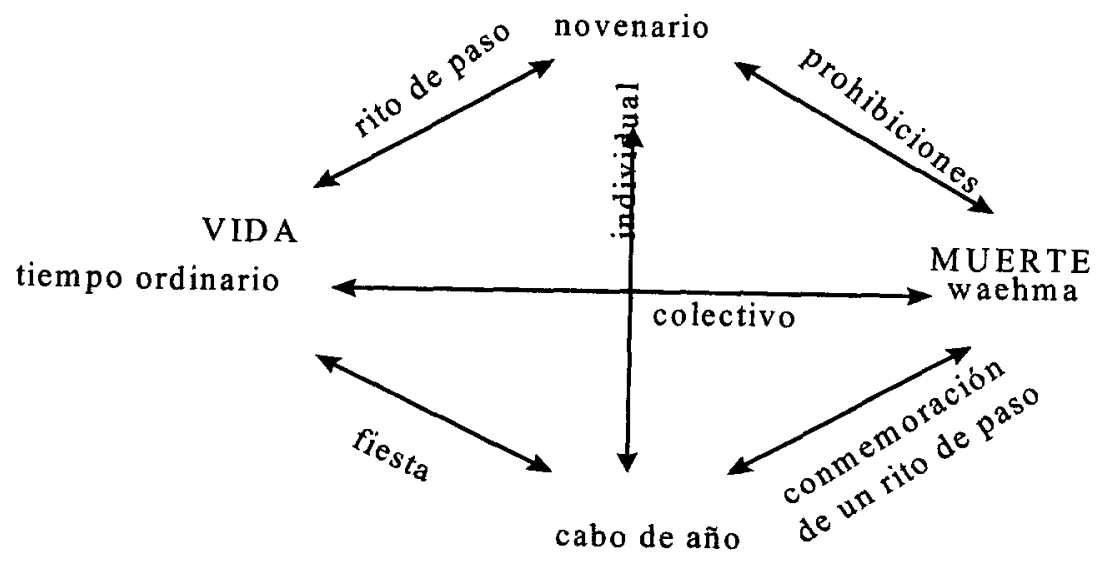


La alternancia vida / muerte que impone su ritmo al ciclo anual, tiene expresiones concretas en el mito, la creencia y el ritual de este pueblo. Su expresión espacial no es más que el otro polo del principio rítmico aquí identificado, que se organiza a través del tebat, las cruces, la iglesia y las enramadas, elementos ya analizados en el capítulo tercero.

Finalmente, se entiende que la cualidad bipartita del tiempo, marcada por la distinción calendárica waehma / wasuktia alude inevitablemente a la problemática fundamental de la vida y la muerte, la transgresión del incesto. La noción de incesto, entendida como la conjunción extrema entre dos elementos que debieran mantenerse a distancia, coincide con el imaginario yaqui. Si en los funerales cae una tormenta, es decir, si en un rito propio de la temporada de secas, caen fuertes lluvias, hay dos elementos que se unen arbitrariamente y el incesto, la conjunción peligrosa se produce, aunque sea tan sólo en ámbito de lo imaginario: "el muerto debió haber sido incestuoso".

Las dos categorías temporales - tiempo ordinario y Cuaresma - en las que se festejan los ritos de paso individuales y se conmemora un rito de muerte respectivamente, se organizan en un ciclo solar asociado al principio lunar, mientras que la muerte indivual, que ocupa un intersticio del sistema, es en sí misma un ritual de carácter doble: el funeral y justo al término de un año solar, el cabo de año. 


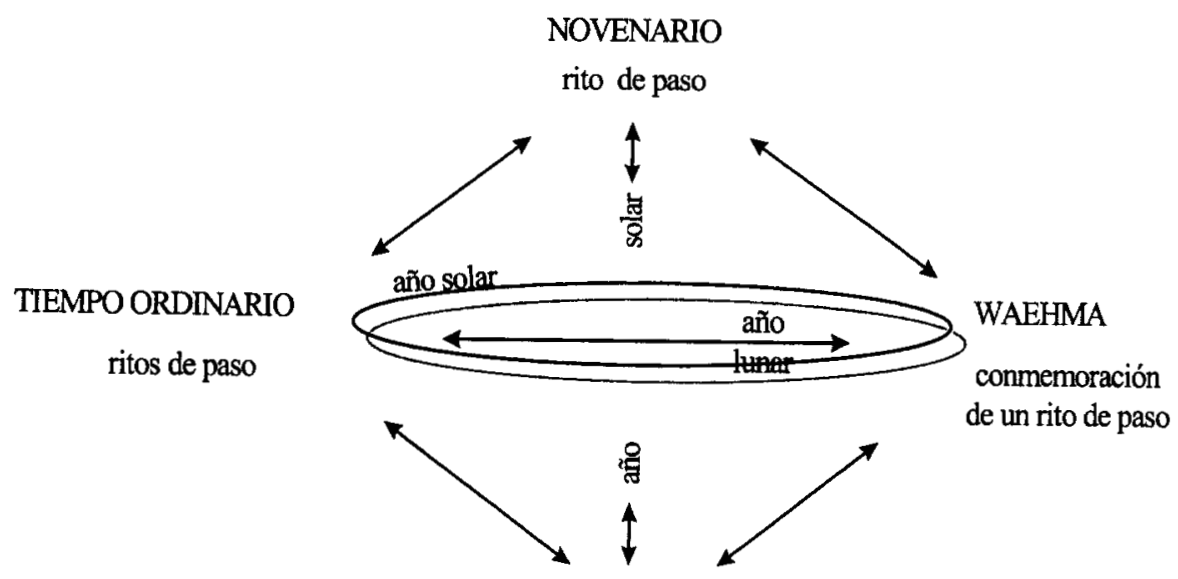

CABO DE AÑO

conmemoración

de un rito de paso 
SISTEMA COSMOLÓGICO 
Este capítulo está dedicado a la exposición del código cosmológico y la reconstrucción del sistema de categorías correspondiente. Con este fin, y sobre la base de la identificación de los elementos constantes en los procesos rituales ya descritos etnográficamente, procederé al análisis de su sintaxis narrativa y ulterior reintegración en el sistema clasificatorio que constituye la base del sistema ritual yaqui. La tercera parte de este capítulo está dedicada a la reconstrucción del sistema de creencias alrededor de los eclipses, al situarse este fenómeno natural como punto de intersección semántica al interior del sistema cosmológico.

Con base en la etnografia del ciclo anual, procederé a reconocer los elementos de signifícación ritual presentes en los procesos rituales yaquis. Ya E.H. Spicer en un artículo póstumo (1994) identifica cinco elementos básicos, los cuales presentaré y discutiré a continuación.

El primero se refiere al proceso de construcción de un espacio sagrado, en particular, a la creación de condiciones sagradas por medio de un esfuerzo humano especializado. Éste puede concretarse en el levantamiento de una enramada de carrizo, hacer un recorrido o conti alrededor del tebat, el levantamiento de cruces en puntos que circundan un espacio sagrado o bien que señalan umbrales; por último orar, ya sea musical o dancísticamente en, o alrededor de un espacio:

"The concept of singing over an area and thus making it sacred has mythological sanction, for the myth of the Singing of the Tribal Boundary tells of making the tribal lands sacred and placing them forever in Yaqui trust, as a result of angels, prophets, and Yaquis moving around the boundary and singing hymns and sacred chants. There is a concept of tachiria, which means something like "sacred light", applied to the area between the Kus mayor and the church during a night of dancing and singing on this ground. Perhaps the yaqui idea is a renewal at regular intervals of the sacredness of areas between crosses and houses or churches. It is certainly clear that a great deal of Yaqui 
effort goes into singing and dancing, and that this activity requires well defined areas." (Spicer 1994:52)

La segunda constante de los rituales yaquis consiste en la toma de posesión de lugares y personas. Este elemento ritual es un gesto análogo al primero, en tanto que ambos reafirman los límites del territorio a partir del reconocimiento de las cruces que marcan la posición de las cuatro esquinas del territorio comunal yaqui. Las numerosas procesiones alrededor del camino de la cruz 0 conti vo'o en waehma no sólo significan la sacralización del recorrido, sino la toma de posesión efectiva del área alrededor de la iglesia y de la iglesia misma. El mismo efecto de significación, pero en este caso, de toma de posesión del territorio yaqui en su conjunto, tiene efecto durante el recorrido que hacen los matachines desde el poblado más septentrional hasta el más meridional, realizando su tekipanoa, en cada una de las visitas que tiene lugar la víspera de la Virgen del Camino en el mes de julio.

En tercer lugar, la coexistencia de dos mundos, uno visible, otro, invisible, es una evidencia (Spicer 1980; Schechner 1988). Ambos coinciden en que se trata de una relación inextricable donde lo visible es en su mayoría cristiano, y lo invisible es, en su mayoría, yaqui; ambas dimensiones están presentes simultáneamente y concurren intermitentemente en el culto. La idea se centra en una diferencia cualitativa entre el mundo precristiano e indiferenciado de los seres naturales, los surem y el mundo cultural de los pueblos, pueplum, donde la gente hace cosas de manera organizada. Los habitantes del huya aniya o mundo natural son inmortales, los del mundo humano pueplum, mortales. La relación entre ambas dimensiones ha sido definida, en distintos momentos, ya sea en términos de mutua exclusión, o de dominación exclusiva de una de ellas en el tiempo ordinario y de la otra durante la waehma; no obstante, mi perspectiva me permite afirmar que, la especificidad del sistema cultural yaqui radica en la simultaneidad total de los dos sistemas de creencias: el que se aproxima al polo pre-jesuita y el que gravita en dirección contraria.

Esta cualidad sincrónica es la que posibilita justamente la comunicación entre los ámbitos, pero sólo los yoremes que han sido iniciados en un cargo pueden mediar a través de los poros, de los instersticios del sistema ritual. Lo logran a través de la manipulación de símbolos que tienen la facultad de servir de 
conectadores, tales como las sewam y la kus, las flores y las cruces.

Sewa aparece en diversos contextos, entre otros, la corona de los matachines recibe este nombre y por sinécdoque, el danzante mismo; el mechón de pelo que los pascolas anudan con un listón rojo en la segunda noche de actividades rituales; los listones atados a la cornamenta del tocado del danzante de venado; la máscara de los chapayekas y el ornamento de sus armas de madera; el papel picado y las hojas de álamo y mezquite que los angelitos arrojan a los fariseos el Sábado de Gloria. La naturaleza polisémica de este signo, ampara la coexistencia de todos estos contextos, puesto que todas sus connotaciones parecen emerger de un solo significado dominante, que se clarifica el Sábado de Gloria, cuando los pascolas y el venado se reúnen con las mujeres de la iglesia y los angelitos para lanzar las flores que destruirán ritualmente a los chapayekas.

Este día, las sewam reúnen al interior de la iglesia, por única ocasión en el año ritual, a los integrantes del grupo de la iglesia con los representantes del huya aniya o religión del monte, residencia del mundo de los inmortales: el venado, los pascolas y sus acompañantes, los músicos.

Durante el Sábado de Gloria, jornada carnavalesca en plena temporada solemne, salen a relucir los intersticios del sistema, se pone de manifiesto la porosidad entre los espacios rituales:

"The huya aniya is always imminent, and the boundaries marking off the seven spheres of space from each other are porous. They are especially porous at decisive ritually powerful times such as Waehma. Then the non-human worlds surrounding the pueblo penetrate to the very heart of the settlement" (Schechner en prensa).

La noción de sewa está igualmente relacionada con las cualidades que constituyen a la persona. El ser yoeme, habitante de los ocho pueblos, conlleva la pertenencia de uno de los dones más preciados, y por mucho, uno de los más importantes, el seataka o cuerpo de flores. La gente nace o no con él y uno de sus signos es la presencia de remolinos en ambos lados de la cabeza, en la parte de atrás o al tope. Un individuo sin seataka es un kia polobe, un "pobrecito" que nunca podrá ser pascola, venado, músico, curandero, cazador, 
jugador, vaquero, ni tendrá facultades para encontrar objetos perdidos y oro.

El concepto sewa representa, más que el bien o lo correcto lo que, en el sentido yaqui, está asociado a los actos sagrados, devociones y deberes rituales. El vocablo mismo es sagrado y se traduce como gracia, indulgencia o gloria. Este don proviene de los surem, al igual que el ute'a, especie de fuerza espiritual para poder realizar el tekia o trabajo ritual. Todos los miembros de los grupos ceremoniales tienen el tekia, es decir, el deber de participar con su persona cuando les sea requerido. Igualmente, los iniciados tienen seataka y por esta razón, al menos uno de los elementos que compone su parafernalia ritual lleva el nombre de sewa, flor.

Por último, el propio Spicer reconoce en los conjuntos de oposiciones rituales una característica propia de la cultura yaqui, constitutiva de su ritmo particular. En este sentido, la oposición más evidente es la que se refiere a los dos bandos presentes en todas las fiestas del tiempo ordinario, representados por colores. El pahkome se agrupa en un bando rojo y otro azul, identificado a menudo como moros y cristianos, y en otras ocasiones de manera simplista se identifica el azul con el bien y el rojo con el mal. En la Cuaresma, el kohtumbre mantiene esta dualidad al interior de su propia jerarquia, los kabayum llevan la bandera azul, los fariseos, la roja. Ambas oposiciones se presentan sincrónicamente y se expresan igualmente en el registro espacial, unos permanecen al lado de la iglesia y los otros al extremo opuesto.

No obstante, la oposición diacrónica entre el kohtumbre y los matachines es una de las que con más frecuencia se verbaliza y se considera como excluyente. Tal insistencia, que podría tomarse como una evidencia, obliga justamente a poner más atención en ella. Si se observa con detenimiento, la división del año en temporada de matachines y temporada del kohtumbre es notable y formulada explícitamente por muchos informantes. Ciertamente, a partir del Miércoles de Ceniza y hasta el tres de mayo se trata de un periodo dominado por el kohtumbre cuando los matachines y sus vírgenes patronas están subordinados y ocultos. Sin embargo, y a pesar de lo que se verbaliza, los matachines no desaparecen del todo en esta temporada: participan en fiestas como la víspera de Domingo de Ramos, y también lo hacen durante la especie de interregnum el Sábado de Gloria cuando tanto los Soldados de la Virgen como los penitentes que honran a Jesús, están presentes en la misma 
ceremonia, ambos en tekia al interior de la iglesia.

Aun así, el concepto de un año dividido en dos estaciones, una de penitencia poblada por tabúes y la otra placentera, $\mathrm{o}$ al menos libre de un buen número de prohibiciones, expresada en las acciones de los actores consagrados ceremonialmente, está plenamente establecido y es parte integral de la vida religiosa.

Además de la dedicación casi exclusiva a la actividad ritual que caracteriza a la waehma, otro de los aspectos que aporta originalidad a este período es que se trata del único rito que pone en marcha simultáneamente los cinco elementos definitorios de los rituales yaquis, combinándolos entre sí de manera no vista en otras ceremonias e introduciendo secuencias exclusivas. En especial, el transcurso del Sábado de Gloria, momentum de la transmutación del kohtumbre, se enfatizan anualmente las oposiciones que dan sentido, luz/oscuridad; dentro/fuera; Vírgenes/Jesús; tratando de encaminar así la vida de las comunidades en dirección contraria a la entropía, esto es, hacia el fortalecimiento permanente de los símbolos.

En este sentido, puede afirmarse que la waehma posee su propia narrativa, planteándose necesariamente la pregunta sobre su contenido. Schechner estudioso de este proceso entre los yoremes de Arizona- formula un cuestionamiento en el sentido que irealmente la waehma se refiere exclusivamente a la Pasión de Cristo o bien éste sintagma es sólo uno entre los posibles? Este autor llega a la conclusión de que al menos dos programas narrativos más están presentes y pueden resumirse en las siguientes formulaciones ¿cómo los yaquis se convirtieron en católicos o civilizados? y ¿quién controla la comunidad? El proceso ritual mismo da su respuesta, puesto que la autoridad está compartida, el año está dividido entre la sociedad de matachines y todo lo que representa - iglesia, lluvias, vírgenes, flores y luzy el kohtumbre ya'ura y todo lo que representa: actitud ambivalente hacia el pensamiento judeocristiano, secas, Jesús, y en general una visión más oscura de la experiencia que no permite dibujar claramente la línea de demarcación entre las tres narrativas simultáneas (Schechner en prensa: 26). 
Por nuestra parte, y consecuentemente con la etnografía y la perspectiva que rige esta tesis, el significado de la waehma no radica en sí misma, sino que establece su sentido a partir de la relación con su contraparte, el tiempo ordinario, $y$ por el conjunto de reglas que determinan la naturaleza de dicha relación. Así, desde el punto de vista de la sintaxis del ciclo anual, la participación del kohtumbre hasta una fecha tan tardía como el 3 de mayo constituiría una situación atípica. Después de todo, se supone que el kohtumbre ya fue vencido el Sábado de Gloria por las flores. No obstante, existen razones por las que se explica su actuación hasta el día de la Santa Cruz, pero no sólo de carácter semántico — como afirma Schechner en el sentido de que una presencia tan poderosa como la del kohtumbre ya'ura no puede ser tan fácilmente borrada de la escena- sino de carácter sintáctico. Las semanas que suceden a la Pascua constituyen el período de reintegración posterior a la liminalidad imperante el Sábado de Gloria, estos días 'vacíos' componen un tiempo transitorio en que los órdenes habituales vuelven a reinar. Así como la aparición de los matachines el Sábado de Gloria puede considerarse como una intrusión temprana de las flores en la waehma, la actuación del kohtumbre el tres de mayo puede considerarse una intrusión tardía de los enmascarados en el transcurso del tiempo ordinario.

De esta manera se responde a otra de las preguntas planteada por Schechner en el sentido de si la prolongación de la participación del kohtumbre hasta el tres de mayo se debe al alargamiento del período liminar o de un rito de integración, y su respuesta - preferentemente semántica- acepta ambos significados. No obstante, con base en su gramática, en el ordenamiento que salta a la vista, mi planteamiento es que se trata de un período liminar breve, concentrado el Sábado de Gloria, mientras que el rito de separación iniciado el Miércoles de Ceniza, alcanza su término el Domingo de Ramos. Mientras que la fase de reintegración, por su parte, comprende del Domingo de Pascua hasta el día de Kusim Taewa, el tres de mayo3.

3 También podría ser considerado desde la óptica de una semiótica teatral. 


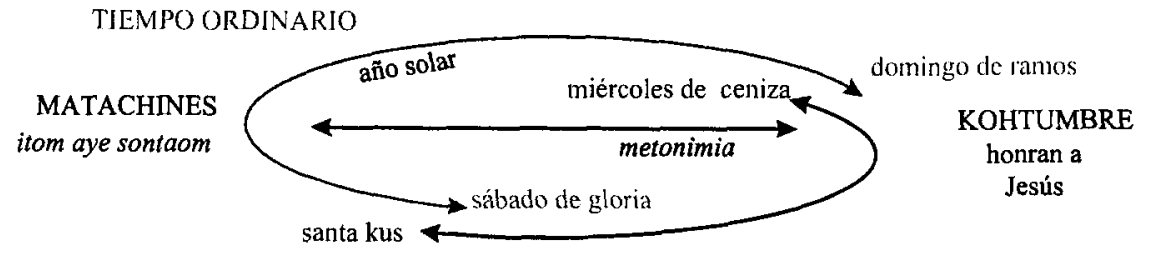

WAEHMA

Así, queda descartada la posición reduccionista que identifica la waehma como el período liminar y que trae aparejada la caracterización simplista del kohtumbre como lo inverso, lo negativo y hasta lo diabólico.4

En este sentido, no adelanto significados ni la interpretación antecede a la lectura, puesto que sólo a partir de la lectura sintagmática es que los actores encuentran su posición en el sistema. Queda claro entonces que a lo largo de la waehma, los yaquis representan tanto su aceptación del catolicismo preferentemente el aprendido en los siglos XVII y XVIII- como, simultáneamente, su resistencia al mismo. En ambas secciones del calendario anual coexisten estos dos polos: durante el tiempo ordinario se privilegia preferentemente el polo de significación católico y en la Cuaresma reluce preferentemente el polo yaqui, por lo que la identidad yaqui puede colocarse como un punto en el contínuo entre ambos. El Sábado de Gloria, sin más, los dos polos se invierten.

Ahora bien, ya sea a partir de la perspectiva semántica o bien del análisis sintáctico, coincido con Schechner cuando afirma que la inversión efectuada el Sábado de Gloria es siempre intrínseca a la religión yaqui:

"Through Waehma the Yaquis act out both, their acceptance of Catholicism (and certain European ways) and their resistance to this very same Catholicism and the European ways."(20)

4 Cfr. Figueroa 1994; Bonfiglioli:1995 y Barrera:1996 
En síntesis, el carácter del ciclo ritual se basa en la relación entre tiempo ordinario y la Cuaresma; el wasuktia y la waehma, dicha relación es un principio organizador con un registro lunar y solar, por lo que de ella pueden derivarse referencias de carácter cosmológico. La primera que salta a la luz es el hecho de que las celebraciones del tiempo ordinario alcanzan su clímax con la víspera de la Virgen del Camino el 2 de julio, fecha que coincide con el paso del sol por el cenit y próxima al solsticio de verano.

Es claro, por tanto, que una de las temáticas de este discurso ritual gira en torno a un código cosmológico, del cual uno de los puntos de referencia más importantes lo constituye el movimiento aparente del sol en la bóveda celeste.

Es a partir del conocimiento de las reglas que conforman este código que se establece la relación efectiva entre el transcurso del día, o sol (los términos para sol y día coinciden en la mayoría de las lenguas utoaztecas) y el año. El conflicto luz - oscuridad es sin duda una de las figuras que expresa tal relación y por lo mismo la encontramos en los dos eventos más importantes del año ritual: durante la waehma, las imágenes de las Tres Marías permanecen ocultas, se trata de las mismas tres vírgenes que son extraídas de las cuevas en la Sierra del Bacatete - territorio sagrado de los yoremes- y que regresan a los pueblos, literalmente salen a la luz y alcanzan el cenit, no sólo metafóricamente, en julio, en la víspera de la Virgen del Camino.

De acuerdo con Beals, estas imágenes de las Tres Marías son el símbolo dominante de la fiesta de julio, y representan respectivamente a las cosechas, los niños y la Pascua (Beals 1945). La asociación de la luz con los niños, las flores y la Virgen queda de manifiesto al observar que la imagen del Santo Niño es custodiada y ocultada durante la waehma por los kabayum, polo luminoso del kohtumbre, hasta que el Sábado de Gloria se exhibe nuevamente al retroceder la oscuridad. Ese día la luz vence junto con las flores y los angelitos.

La asusencia de los elementos asociados al polo luminoso en Tinieblah, permite suponer un programa narrativo en los siguientes términos: el Miércoles Santo, Oficio de Tinieblas, vence la oscuridad y los fariseos irrumpen en la iglesia; el Sábado de Gloria son expulsados, derrotados de nuevo por el principio luminoso. Asimismo, la formación que rige en las 
procesiones de la Cuaresma va narrando en lenguaje situacional el conflicto entre luz y oscuridad propio de la estación: la oscuridad rodea a la luz cuando mujeres y niños marchan dentro, mientras los varones lo hacen por los bordes del grupo en el conti más solemne de todos, cuando todo está a punto de revertirse, al atardecer del Viernes Santo.

La segunda temática a que alude la principal oposición del calendario litúrgico se refiere al reconocimiento de las cinco direcciones del mundo: la waehma, rito temporal - cíclico, está dominada por contis o procesiones circulares que se realizan en sentido antihorario. Este recorrido circular en el plano horizontal corresponde a la kus y su contraparte durante el tiempo ordinario la fiesta dedicada a la Virgen del Camino - constituye un recorrido espacial en sentido norte - sur, tal como lo confirman las visitas o posadas que los matachines realizan de pueblo en pueblo, pero también en el sentido vertical: los ascensos a los cerros y descensos a las cuevas recuerdan la existencia de un eje cosmológico.

Este eje vertical, que atraviesa sincrónicamente el territorio, está presente claramente en la mitología ${ }^{5}$. Basta recordar cómo los mitos disponen los tres órdenes coexistentes, los tres planos del mundo yoreme, a saber, el mundo precristiano de los surem, el de los habitantes de los pueblos yaquis pueplum y el de los iniciados, las flores, sewam.

El mito cosmogónico más extendido sanciona el origen de los yaquis como hijos de Yomumuli, la mujer que logra traducir al árbol parlante, quien en algunas versiones es una gemela wowo'ri, producto, como veremos más adelante, de la escisión causada por el rayo o por la exposición a un eclipse. Este relato sanciona la aparición de la cultura, ya que "antes no existía la agricultura y los animales no sabían dónde les correspondía vivir". La relación de oposición entre naturaleza y cultura opera también entre la madre terrestre de los surem, Yomumuli y el cielo -donde está Dios- mediada por el árbol parlante. Fabila lo describe como "un árbol profeta de color cenizo que

5 Hago referencia a los resultados de mi estudio de once mitos yaquis publicado en Análisis estructural de la mitología yaqui, INAH-UAM, Colección Científica núm. 183, México, 1989 
existía en la mitad de la comarca y el cual hablando como gente sabia, enseñó a los indios el nombre de todos los astros del cielo" (1978:250)

A pesar de la sabiduría de los hombrecitos surem, las enseñanzas de este árbol sólo eran inteligibles para Yomumuli, pero su contenido no le resulta cómodo, dado que este árbol predice la conquista, evangelización y sedentarización. Yomumuli hace caso omiso de las profecías, conoce la verdad y la acepta, pero prefiere irse de la tierra de los surem y tomar rumbo hacia las nubes del norte. En otras versiones Yomumuli quema la vara profeta con un cigarrillo gigantesco (Toor, 1976:251).

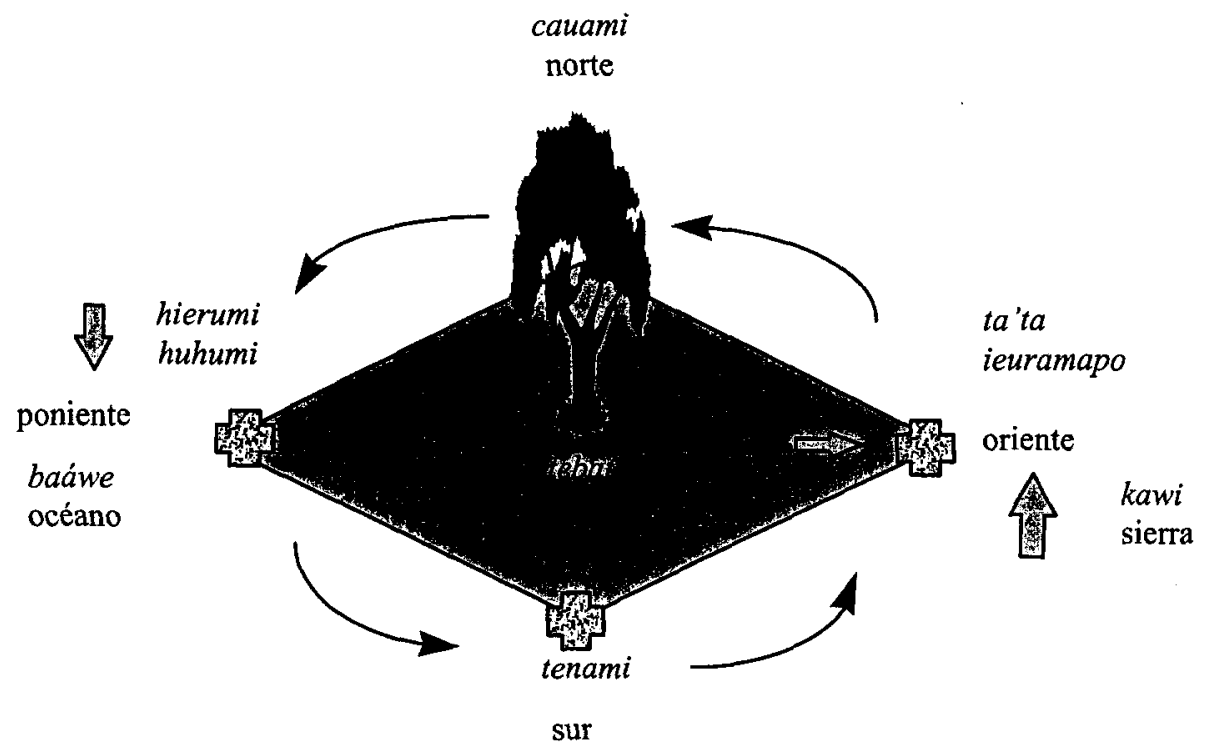

Aquellos surem que, por su parte, rechazan la posibilidad de la conquista, descienden bajo tierra o se refugian en el mar. Tanto los surem como Yomumuli son condenados a la vida no humana, pre-social, al no aceptar las profecías del árbol parlante. No obstante los surem, como avatar de ballenas y sirenas, se convierten en protectores de los yaquis. Junto con el chivato, amo 
de la danza de pascola y el bwiya toli, amo de los instrumentos musicales, los surem están asociados, finalmente, al huya aniya y la categoría de lo bajo.

La aceptación de la cristianización por parte de los surem tiene como consecuencia el origen de los propios yaquis quienes "crecieron más que los surem", y viven en el punto intermedio entre el mundo celeste de Yomumuli y el mundo subterráneo de los surem, en un equilibrio que se mantiene por medio del lenguaje perenne de los ritos.

Por otra parte, no se cuestiona el hecho de que en la tradición yaqui haya relatos que podrían considerarse como excluyentes: el origen del propio territorio -el mito de la Inundación y los Profetas (Spicer 1980) — apela a un principio escatológico o de sucesivo perfeccionamiento de la humanidad a través de destrucciones. El mito del diluvio como una depuración de la humanidad tiene igualmente su contraparte lógica. La inmersión en líquido no siempre es producto de una lluvia prolongada como en la historia de Caldea, también existe la posibilidad de que las lágrimas de un niño llorón provoquen la inundación, como en versiones del Sudoeste americano, o bien, como en el caso yaqui, que el agua surja de la tierra en dirección ascendente. Si en el momento de la inundación, el mundo se convierte en un excesivo contenedor de líquido, y esta cualidad deviene en el defecto que provoca la desaparición de la humanidad; los mitos del mundo desfondado convierten al mundo en su contrario. El mundo desfondado es el motivo de varios mitos de la macroregión como los tarahumara y kiliwa (Lumholtz 1981 y Ochoa Zazueta 1978) donde el mundo requiere de una reparación para poder dar albergue a los hombres; en la versión kiliwa el mundo se desborda antes de que el demiurgo proceda a usar sus propios testículos como recipiente para proveer de sostén al universo, o en el caso rarámuri los hombres inician la danza sagrada para apisonar la tierra que de otra manera no podría sostenerlos. Como se ve, la pregunta no sería entonces el por qué de sus semejanzas evidentes, sino cómo a través de sus diferencias corresponden a una matriz lógica de transformaciones ${ }^{6}$.

6 Tal multiplicidad de versiones no es para que el receptor seleccione una de ellas, sino para arribar a través de todas a un mensaje codificado que plantea las soluciones lógicas al problema del origen. Leach (1980) afirma que la multiplicidad de versiones en el contexto religioso, más que conducir a una situación de "ruido", confirma el carácter polivalente del pensamiento mágico-religioso. 
Una de dichas matrices corresponde al ejemplo mesomericano. Este caso sirve como modelo privilegiado para ilustrar cómo en una misma tradición coincide una variedad de posibilidades: el cuerpo de una deidad gigante en sacrificio, un perfeccionamiento sucesivo de humanidades a través de destrucciones y surgimientos, el diluvio universal y la pareja primordial. Expertos como López Austin (1994) y Graulich (1987) afirman que la mitología mesoamericana, a pesar de la diversidad de lenguas y pueblos, es fundamentalmente una y que se refiere siempre a una misma historia: aquélla del universo, de un pueblo, de una era o de un año, comparada o asimilada a la historia de un solo día. Este tema proporciona el modelo de las oposiciones como luz y oscuridad; y sigue un esquema que se refiere a: la unión de los contrarios - disyunción de los contrarios - equilibrio de los contrarios, basado en su alternancia.

El ciclo que se instaura restablece a la larga, el equilibrio, la unión de los contrarios, el paraíso y la vida sin fin, Tamoanchan, Tollan, Tlalocan, Aztlan y por supuesto, la Gloria en el caso yaqui. La pareja suprema y sus criaturas viven en armonía, al igual que los pueblos en su país de origen (los surem), la disyunción resulta de una transgresión (no aceptar las profecías): es el exilio del paraíso (cristianización) y de nuevo el equilibrio de los contrarios se instaura por la emergencia del sol que triunfa sobre la oscuridad (actuado el Sábado de Gloria), por el establecimiento del pueblo nómada en la Tierra Prometida, es el advenimiento de la alternancia del día y la noche, la época de secas y la de lluvias continuamente reafirmada por el ciclo ritual.

El movimiento aparente del sol marca el comienzo de una serie de ciclos cortos, cuyo modelo a escala corresponde al de una era: unión de los contrarios que corresponde al atardecer; el Inframundo a la noche y el Cielo al día. Es al atardecer cuando el mundo está iluminado por un 'falso sol', es al atardecer cuando verdaderamente inicia el ciclo, y por ende su unidad, la fiesta; por la noche viaja al mundo subterráneo y durante el día aparece de nuevo el sol verdadero.

En la tradición mesoamericana, los tres niveles del universo -cielo, tierra, inframundo- están asociados a las tres partes del día o del año. El atardecer es el paraíso de Tlaloc, el Cincalco, Tamoanchan la tierra. La noche es 
Mictlan, el inframundo. La mañana es la casa del sol en el cielo. Las eras de la humanidad son también como un día, puesto que incluso se les da el nombre de soles. Después de haber alcanzado su apogeo, el sol deviene en un astro indiferenciado y todo se pone listo para separarse en sus pares contrarios. El modelo es entonces, unidad - indiferenciación - dualidad, que se manifiesta como inmovilidad - movilidad - alternancia.

En este sentido y sin pretender establecer más lazos que los ya proporcionados por la comunidad histórica y lingüística, el modelo yaqui se situaría como un momento más del conjunto de transformaciones mesoamericano. $\mathrm{O}$ más bien, como ilustración de una de las posibilidades que dicho modelo hace posible. 


\section{ESTRUCTURA SINTÁCTICA}

La representación del esquema clasificatorio que subyace a la cosmología yaqui parte, como ya se mencionó, de la distinción de los dos principios que rigen el ciclo ritual anual: el solar (1) —que determina las fechas fijas-y el lunar (2) que establece el período cuaresmal, instituyendo así las dos grandes secciones del tiempo: tiempo ordinario y Cuaresma, cuyo contenido semántico corresponde a la oposición vida/muerte.

El tiempo ordinario o wasuktia celebra, en las fechas designadas por el ciclo solar, tanto los ritos que marcan hitos significativos en la vida colectiva de las comunidades, como aquéllos que facilitan el paso de una etapa a otra en la vida de los individuos. Aparece entonces la expresión colectiva o individual, que deriva en una sistema de cuatro categorías:

\begin{tabular}{|c|c|}
\hline solar colectivo & lunar individual \\
\hline solar individual & lunar colectivo \\
\hline
\end{tabular}

que corresponde a un sistema ritual de cuatro categorías que agrupa a todos los ritos que tienen lugar a lo largo del año:

\begin{tabular}{|c|c|c|}
\hline fiestas del wasuktia & ritos de paso \\
\hline funeral-cabo de año & waehma \\
\hline
\end{tabular}


En este esquema cuatripartita se agrupan todos los ritos que fueron descritos sintagmáticamente, es decir, en el eje temporal, en el capítulo dedicado a la descripción etnográfica. De manera que la clasificación aparente, tal como se presentaba en el programa narrativo sintagmático del año ritual, resulta en una estructura de cuatro términos. Este sistema reconoce, en un nivel más profundo, la existencia de cuatro relaciones que sintetizan las siguientes operaciones rituales:

\begin{tabular}{|c|c|}
\hline ciclo vital colectivo & ciclo vital individual \\
\hline $\begin{array}{c}\text { conmemoración de rito fúnebre } \\
\text { individual }\end{array}$ & conmemoración colectiva de rito \\
\hline
\end{tabular}

Este sistema, no obstante, se vive como una visión del mundo, derivada no sólo de la mitología, sino también de la combinación particular de unidades mínimas de significación ritual y que hacen referencia a ejes del código cosmológico. Dichos ejes establecen compartimentos sobre la experiencia cognitiva sobre el mundo y narran, en lenguaje situacional, una cosmología particular. Uno de ellos es el eje que transita verticalmente por los tres planos del mundo, verbigracia el árbol parlante del mito "Yomumuli y los surem"; y la elipse, el "camino de la cruz" o conti.

De manera que la representación esquemática de esta matriz considera ocho categorías, resultantes de la multiplicación de los cuatro conjuntos rituales por los dos ejes: 


\begin{tabular}{|c|c|}
\hline $\begin{array}{l}\text { ciclo solar colectivo vital } \\
\text { fiestas del wasuktia } \\
\text { dirección abajo- arriba }\end{array}$ & $\begin{array}{l}\text { ciclo solar, conmemoración de } \\
\text { muerte individual } \\
\text { funeral-cabo de año } \\
\text { eje cosmológico arriba - abajo }\end{array}$ \\
\hline $\begin{array}{l}\text { ciclo lunar individual vital } \\
\text { ritos de paso } \\
\text { energía centrípeta }\end{array}$ & $\begin{array}{l}\text { ciclo lunar conmemoración } \\
\text { colectiva de rito de muerte } \\
\text { waehma } \\
\text { energía centrífuga }\end{array}$ \\
\hline $\begin{array}{l}\text { ciclo lunar, conmemoración } \\
\text { colectiva de rito muerte } \\
\text { moehmo } \\
\text { movimiento eliptico horario }\end{array}$ & $\begin{array}{c}\text { ciclo solar colectivo vital } \\
\text { fiestas del wasuktia } \\
\text { movimiento elíptico antihorario }\end{array}$ \\
\hline $\begin{array}{c}\text { ciclo solar, conmemoración de } \\
\text { muerte individual } \\
\text { funeral-cabo de año } \\
\text { categoría dentro-fuera }\end{array}$ & $\begin{array}{l}\text { ciclo lunar individual vital } \\
\text { ritos de paso } \\
\text { categoría fuera-dentro }\end{array}$ \\
\hline
\end{tabular}

Además de ser coherente desde el punto de vista sintáctico, este esquema respeta el ritmo cultural y numérico del sistema vigesimal yaqui: ocho es "dos veces cuatro" wojnaiki, diez es wojmámni "dos veces cinco" y senataka es la unidad, veinte, o un cuerpo.

Cada una de las ocho categorías encuentra su posición necesaria dada la estructura de oposiciones pertinente, lo que permite trazar el contenido semántico de ellas.

1) La primera relación significativa corresponde a la que marca el eje vertical que comunica a los pueplum con el sewa ania; es decir, a los habitantes de los ocho pueblos con el universo de los iniciados, con el mundo de los que cuentan con seataka. Este eje abajo-arriba-abajo está presente tanto en los ritos del ciclo solar colectivo como en la conmemoración de la muerte 
individual al cabo de un año solar, es decir, el funeral - cabo de año. Los principales marcadores del eje cosmológico vertical en las fiestas del tiempo ordinario son los cohetes que, además de cumplir con el cometido de "alejar al diablo de las fiestas", son las señales que delimitan el tiempo y espacio sagrados, puesto que marcan el inicio y el término de los tres tiempos del pahko: la víspera, la fiesta y la misa. Al encender los cohetes, los pascolas señalan la existencia de un espacio encantado. El mito refiere que los cohetes los arrojó el primer pascola con la finalidad de ahuyentar al diablo, después de haber recibido del bwiya toli (especie de rata silvestre) los elementos indispensables para las fiestas: el tambor y la flauta.

Así como los instrumentos musicales son extraídos de la tierra, el tabaco hiak viva, y las banderas bantelo se mueven en dirección abajo- arriba. El papel del tabaco es de suma importancia puesto que, si éste es lo que interrumpe la comunicación entre el mundo de los surem y el de los pueblos, tal como el gesto de la gemela Yomumuli al arrojar un cigarrillo gigantesco (versión del mito en Toor 1976:251), este mismo elemento es el que restituye la porosidad entre ambos órdenes. Basta recordar que un gesto obligado de los danzantes de pascola consiste en fumar constantemente y ofrecer cigarrillos a los presentes.

La fiesta que representa la culminación del wasuktia, la celebración de la Virgen del Camino, sintetiza este principio con el recorrido ascendente de los maestros y matachines yaquis en búsqueda de las imágenes de las Tres Marías en un lugar de la Sierra del Bacatete.

$\mathrm{Su}$ contraparte semántica corresponde al eje arriba-abajo, es decir, el eje cosmológico que corresponde al tránsito del mundo liminar de los recién fallecidos y sus padrinos de funeral, hacia el inframundo. Cabe recordar que es el medio acuático, asociado también al interior de los cerros, el que corresponde a la imagen yaqui del mundo abisal. En él habita kurúes o serpiente de siete cabezas que se alimenta de los cuerpos de los incestuosos, y los surem, antepasados imaginarios de los yaquis. Paralelamente, y de acuerdo con el mito, los surem que rechazaron ser bautizados se convirtieron en hormigas y animalitos del monte, seres todos ellos pertenecientes al huya aniya (Olavarría 1989). 
Sólo en determinadas ocasiones es posible la comunicación entre ambos mundos, los funerales - cabo de año es una de ellas: cuando en el transcurso de uno de estos ritos cae una tormenta con rayos y truenos es síntoma de incesto cometido por el muerto. Es entonces cuando los habitantes del mundo subacuático reclaman su carne y lo hacen enviando a Suawaka, el rayo y la estrella fugaz, en señal de advertencia.

La trayectoria vertical de su mensaje, en dirección arriba-abajo es la contraparte de los cohetes festivos de las fiestas patronales del tiempo ordinario. Tanto cohetes como rayos conectan a los participantes de los ritos con los seres del inframundo, como la serpiente acuática, por un lado; o con el mundo flor sewa ania, por el otro.

\section{SOL}

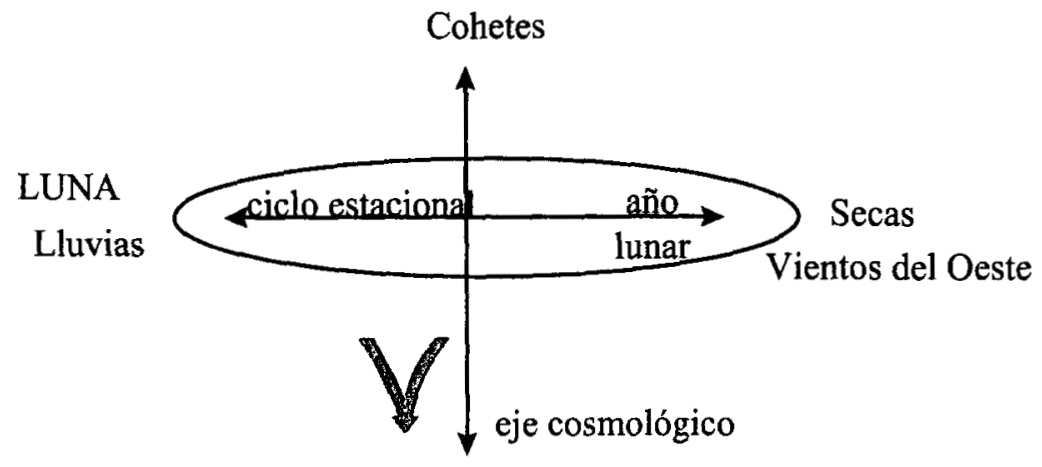

Rayos, truenos, tormentas

2) El siguiente par contrapone dos conjuntos rituales determinados por el registro lunar: los ritos de paso individuales y la waehma. Es decir, la realización efectiva de un rito de paso, frente a la conmemoración colectiva de un rito de muerte. La temática del primer conjunto de ritos no es sino la muerte simbólica de los neófitos, en su transformación ontológica, los neófitos comparten los símbolos propios de los yoremes cuando mueren: deben ir descalzos o con huaraches de tres puntadas y sin sombrero. Por su 
lado, la conmemoración colectiva de un rito de paso, la muerte del Judas escenificada en la semana mayor, es otra muerte, la de un monigote de paja con todos los símbolos de los yoris, calzado y con sombrero, radiograbadora y chacos.

Desde el punto de vista del rito, la muerte de los neófitos tiene que ver tanto con la energía centrípeta que los asocia a lo bajo, como con los signos que les son impuestos por los padrinos. Siempre pasivos, los neófitos reciben el rosario kusim, la señal de la cruz de sus painos y mainas y son llevados al interior de la iglesia. Por su parte, la muerte del Judas, del malhumor, ocurre en el tebat, espacio sagrado también pero exterior a la iglesia, cuando los únicos cohetes que se queman en este período ritual, aquéllos que están clavados en el torso del muñeco, estallan junto con las sewam.

3) La tercera relación evoca el reconocimiento del recorrido elíptico de la procesión, el conti, y atañe a la oposición de los registros solar y lunar. El Sábado de Gloria, el anticlímax de la waehma es la única fecha en que la procesión corre en sentido horario; en el resto de las fechas rituales del ciclo, la procesión gira en sentido contrario a las manecillas del reloj. Las procesiones, que parten invariablemente del oriente, evocan así, el movimiento aparente del sol en la bóveda celeste.

4) Por último, la categoría dentro/fuera atañe al campo semántico que rodea al espacio sagrado de la iglesia. El movimiento en forma de cruz que los padrinos de muerte realizan con el cadáver en dirección a los cinco puntos durante el funeral, así como el viaje del cortejo hacia el cementerio, refiere al par de categorías mencionadas. Por la otra parte, una de las constantes de los ritos de paso individuales es el número fijo de entradas y salidas de la iglesia, similar al del kohtumbre en Tinieblas y Sábado de Gloria. De esta manera, tanto la conmemoración de la muerte individual, que se celebra conforme a una regla solar, como los ritos de paso que tienen verificativo en el período comprendido entre la última luna nueva de invierno y la última de primavera, apelan a la sintaxis dentro/fuera del espacio sagrado.

De manera que, al sintetizar las categorías pertinentes de este sistema, se obtiene el siguiente cuadro que no es sino una sustitución en sus elementos mínimos: 


\begin{tabular}{|l|ll|}
\hline $\begin{array}{l}\text { cohetes en las } \\
\text { fiestas del santoral }\end{array}$ & $\begin{array}{l}\text { rayos durante el } \\
\text { funeral y cabo de año }\end{array}$ \\
\hline $\begin{array}{l}\text { cuerpo de los neófitos } \\
\text { en los ritos de paso }\end{array}$ & $\begin{array}{l}\text { explosión del Judas el } \\
\text { Sábado de Gloria }\end{array}$ \\
\hline $\begin{array}{l}\text { Sábado de Gloria } \\
\text { cadáver durante } \\
\text { funeral }\end{array}$ & $\begin{array}{l}\text { contis en las } \\
\text { fiestas del santoral }\end{array}$ \\
\hline
\end{tabular}

Así, con base en las reglas del análisis sintáctico, se obtiene una lista discreta de términos que conforman el mínimo de significación ritual, o ritemas. Tales elementos se repiten en todos los ritos estudiados y conforman haces de relaciones rituales, en este caso:

\begin{tabular}{|c|c|}
\hline dentro & fuera \\
\hline antihorario & horario \\
\hline arriba & abajo \\
\hline
\end{tabular}

Estas categorías están rodeadas por una semántica particular y refieren, en última instancia, una cosmología o visión del mundo. 
1) Así, el par dentro-fuera apela preferentemente a la temática de la vida y muerte: muerte real de los yoremes, muerte imaginaria del Judas y muerte ritual de los neófitos.

2) El movimiento antihorario frente al movimiento horario, opone el wasuktia a la waehma, programa narrativo que enfrenta luz a oscuridad.

3) Por último, sólo los iniciados están capacitados para restablecer ritualmente la comunicación, tanto con el sewa ania como con el huya ania, reconociendo así, el eje arriba- abajo-arriba.

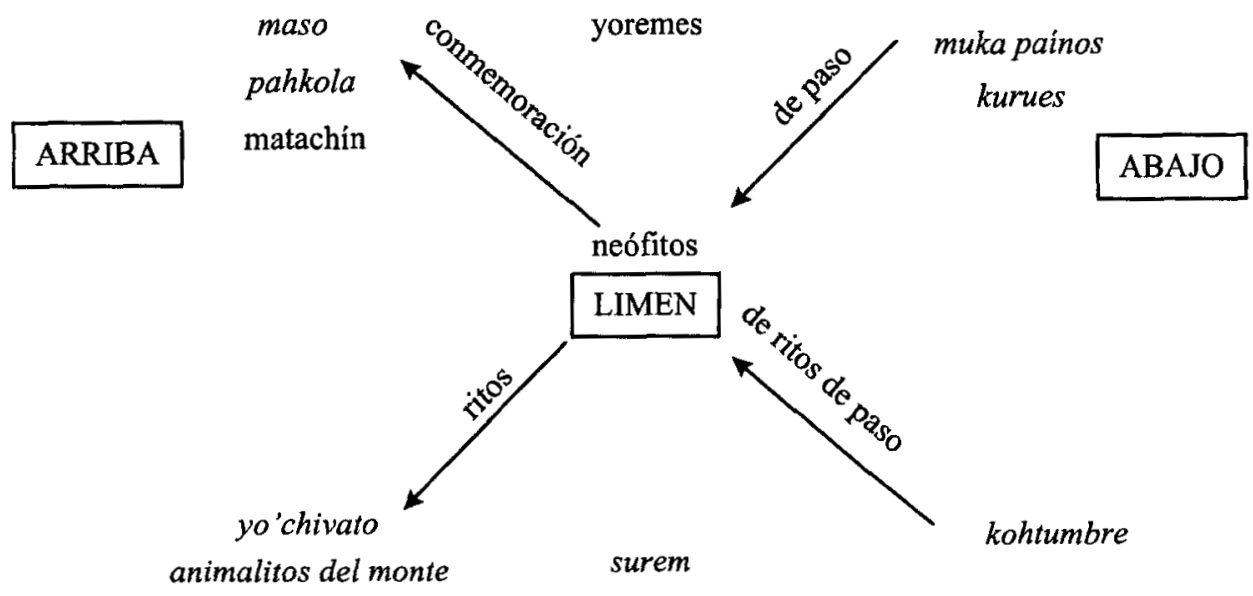

Otra manera de representar este esquema es como un conjunto de tres planos horizontales, lo que resulta en: 


\begin{tabular}{|ccc|}
\hline antihumanos $\quad$ flores & $\begin{array}{c}\text { SEWA ANIA } \\
\text { humanos }\end{array}$ & animales \\
\hline $\begin{array}{c}\text { MUNDO vivos en ritos de paso y muertos en ritos de paso } \\
\text { INTERMEDIO }\end{array}$ & surem & animalitos del monte \\
\hline Kurues & HUYA ANIYA & \\
\hline
\end{tabular}

Si observamos el esquema anterior como un conjunto de tres planos verticales, se trata de la representación etnocéntrica - en el sentido literal- del mundo, expresada en los términos territoriales descritos en el capítulo tercero:

\begin{tabular}{|c|c|c|}
\hline otra república & $\begin{array}{c}\text { valle } \\
\text { pueblos tebat iglesia } \\
\text { cementerio }\end{array}$ & sierra \\
océano & monte \\
\hline
\end{tabular}

No obstante, una representación de este tipo permite dar cuenta del sistema en su complejidad: 


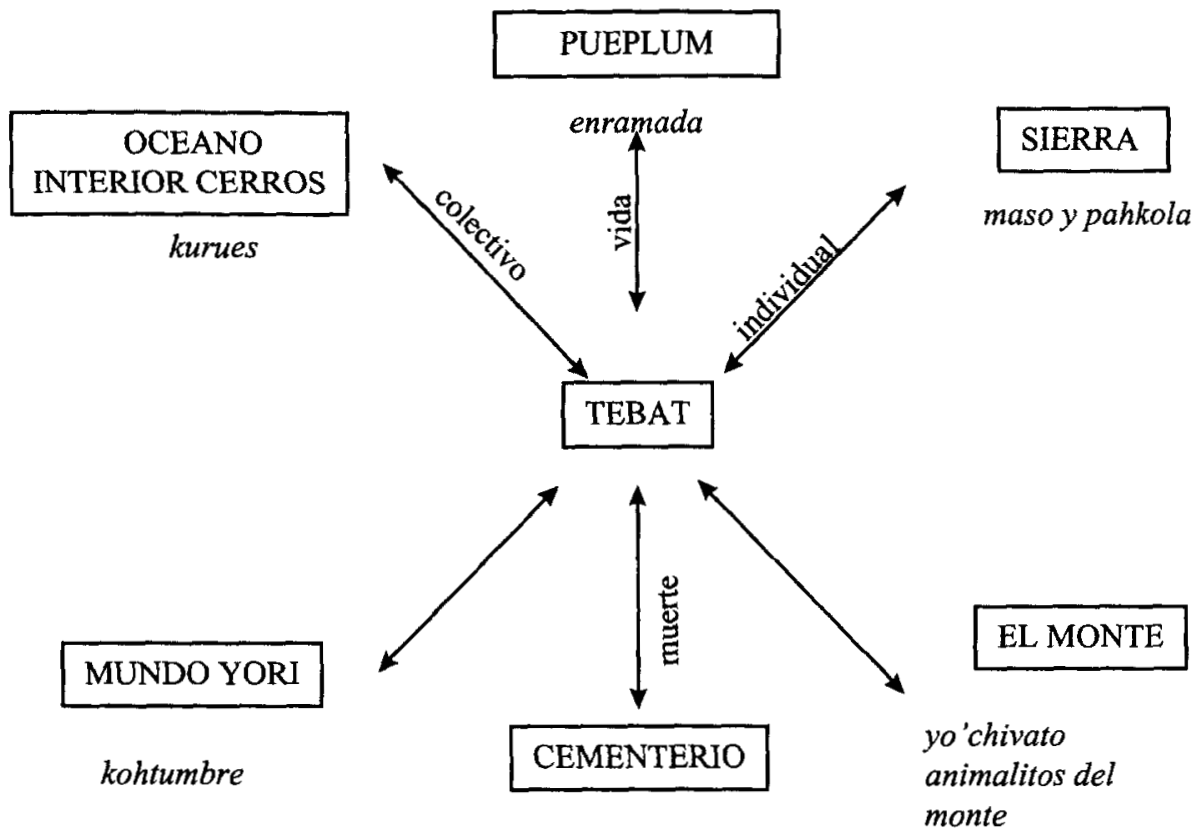

Con base en este planteamiento, es claro que los "lugares" de mayor peligro estén representados justamente por los umbrales entre las categorias y que deban estar señalados o protegidos por símbolos de cualidad sagrada. Tanto el espacio demarcado en todos los ritos, como el movimiento de las procesiones, está señalado por cruces. La kus está presente al interior de la iglesia, en el tebat, en el camino de la cruz o conti vo'o, en los umbrales de las casas, y en el interior en los altares domésticos, el rosario que portan los iniciados se llama kusim y el ornato de las máscaras de pascola consiste también en una cruz dibujada en la frente. El análisis del sistema de iconos (en el capítulo VI) demostrará que, junto con las flores sewam, las cruces constituyen los signos que permiten acceder al carácter sagrado de seres, tiempos, espacios y son los indicadores de la vocación ritual de los yoremes?

${ }^{7}$ Para Van Gennep la instalación ceremonial de límites físicos tiene como objeto la apropiación por parte de un grupo de un espacio determinado, de manera que penetrar en él, siendo extraño, equivale a cometer un sacrilegio, una profanación. Tales límites nunca ocupan toda la frontera, sino únicamente los sitios de paso. (1909:21-22) 


\section{INCESTO SIMBÓLICO: LOS ECLIPSES}

Así como resulta anómalo e incluso peligroso bailar matachín o ser fiestero sin haber recibido la kus, igualmente resultarán peligrosos los momentos en que se conjuntan elementos que en el mundo de las ideas deben pertenecer a categorías distintas ${ }^{8}$. Ello ocurre en ocasión de los eclipses solares y lunares, fenómeno que ocupa el mismo sitio, en el mundo de las representaciones, que las transposiciones estacionales, tales como el caso de la presencia de tormentas en época de secas (rayos durante los funerales).

Tuve la suerte de presenciar un eclipse total de luna en la comunidad yaqui de Loma de Guamúchil el 3 de abril de 1996, Miércoles Santo, cuando tuvo lugar, mécha múkuk, literalmente "luna muerta", alrededor de las seis de la tarde. Tuve la mala suerte de que, por tratarse de un día sagrado de la waehma, y por tanto sujeto a la prohibición de efectuar cualquier otro tipo de rito, dicho evento no produjo actitud especial alguna entre la población. En situaciones "normales", por así llamarlas, el eclipse hubiera sido objeto de cencerrada, ocultamiento y temor de su efecto sobre las mujeres encintas y sus hijos. Ese día en particular, sólo llamó mi atención la reacción de una joven embarazada que sintió algunos mareos y se dispuso a "darle una vuelta a su casa" siguiendo las instrucciones de su suegra, cantora y curandera. Otra de las explicaciones que me dio doña Clara Valencia, jefa de familia e hija de un curandero yoreme muy conocido en la región, fue que no había peligro de que este eclipse tuviese efectos negativos sobre el hijo de la joven, ya que se encontraba en los últimos meses de embarazo. Si hubiera estado en los tres primeros, dijo, podría pasarle lo mismo que a otro niño que nació con la "manita cucha" por haberse expuesto a un eclipse.

Ambas reacciones ilustran un momento particular de las creencias yaquis en torno a este momento de conjunción peligrosa. La primera recomendación, el dar una vuelta alrededor de la casa, está inscrita en un registro tradicional. Recordemos que las vueltas y procesiones evocan el movimiento del astro, dar

B Una de las creencias más frecuentes en este sentido es que si alguien no iniciado se coloca en el rostro una máscara sewa, enfermará del estómago. 
una vuelta, aunque sólo sea al solar doméstico, es un rito simpático que pretende restituir el movimiento aparente del astro. La segunda versión es más compleja, puesto que están presentes dos códigos: el que remite a la creencia generalizada de la enfermedad de mescualo ${ }^{9}$ o mordido por la luna, junto con una racionalización montada sobre un conocimiento que apela a un código científico. Sin discutir la legitimidad de las versiones, es su misma coexistencia y aceptación lo que me pregunto e intento explicar en este apartado.

Esta complejidad es ilustrativa del momento en que se encuentra el conocimiento etnoastronómico del grupo, restringido ahora a algunos ancianos. Se reconoce a Venus, en español como Lucero, y en su doble cualidad, como la estrella de la mañana ma'ali choki y la estrella de la tarde burere choki. Estos dos nombres refieren a dos tipos de venado, la cría y el adulto. No encontré, sin embargo, un testimonio que permita relacionarlos directamente con el masochoki, es decir, el venado estrella, o danzante de venado, sin embargo es claro que el danzante de venado evoca al planeta.

La constelación de la Osa Mayor se conoce como lomingo, domingo, por ser siete las estrellas y siete los días de la semana. Las Pléyades son las choki aroam, probablemente el arado; baji chokim son las tres estrellas, las cabrillas. Un cometa es choki hisam, cola o penacho de estrellas, y trae malos augurios como la guerra, como lo fue el Halley durante el periodo revolucionario. La Vía Láctea es cucharón de cenizas o napowihtei y se dice que es el camino de la Asunción de María, también se identifica la estrella del norte y dos más

9 El Vocabulario en Lengua Castellana y Mexicana de Molina asienta: "Tonatiuh cualo: el sol es comido". De acuerdo con Sahagún "Cuando se eclipsa el sol parece colorado, parece que se desasosiega o se turba el sol o se remece o revuelve y amarillece mucho. La gente luego se alborota y tómales gran temor... y luego buscaban los hombres de cabellos blancos y caras blancas los sacrificaban al sol". En maya yucateco chi'bil kin es eclipsarse el sol, porque en los eclipses la sombra o parte eclipsada es corva, como la señal que dejan los dientes en las mordidas o bocados quitados, reporta el Diccionario Maya Cordemex; o bien la misma palabra designa tanto el eclipse en sí como la enfermedad que produce, tal como lo asienta el Diccionario de Pío Pérez concluido en 1875: "Chibakin: eclipse de sol. Mancha de cuerpo o lunar. Chiba u: eclipse de luna. Las manchas o mancha morada que suelen tener los niños desde su nacimiento y si son encarnadas las atribuyen a los eclipses de sol a que salen las preñadas." 
como "los ojos de Santa Lucía".

Los lunares o falta de algún miembro, síntoma conocido como mescualo, se centra en la idea de que el sol y la luna ${ }^{10}$ son atacados, mordidos, comidos o se encuentran en peligro de muerte en el momento del eclipse. Existe un conjunto de creencias que se presenta con cierta homogeneidad, tanto en el ámbito de las sociedades mesoamericanas como entre pueblos indígenas contemporáneos del área ${ }^{11}$. Los agentes que perpetran este ataque son diversos: el jaguar, las hormigas, la iguana, una serpiente celeste, el diablo o simplemente un animal, o bien, es la luna quien se come al sol. La respuesta más frecuente para contrarrestar esta situación, desde el punto de vista ritual, consiste en producir un gran ruido o levantar una hoguera en el centro del poblado. De no llevarse a cabo tales acciones, se corre el riesgo de que los utensilios domésticos se rebelen contra sus dueños, que el jaguar celestial o cualquier otro de los personajes astrales descienda del cielo para devorar a las criaturas terrestres, 0 que los espíritus de los muertos se levanten para devorar, a su vez, a los vivos.

Los eclipses tratan pues, de una conjunción peligrosa, de la ruptura de un orden armónico a partir de la intrusión de un elemento ajeno que intenta captar un elemento que provoca desunión. En el plano cosmológico, el eclipse se presenta como equivalente de la subversión de los vínculos de alianza que son

${ }^{10}$ Sol y Luna, en este texto, no se refieren a objetos fisicos sino a unidades culturales: "Cuando se dice que la expresión /Estrella de la Tarde/ denota cierto "objeto fisico", grande y de forma esférica, que viaja por el espacio a varios millones de millas de la Tierra (Quines, 1953, 1) habría que decir en realidad que: la expresión en cuestión denota cierta unidad cultural correspondiente, a la cual se refiere el hablante, y que éste ha recibido descrita de ese modo de la cultura en que vive, sin haber tenido experiencia nunca del referente real. (...) las cosas se conocían sólo a través de las unidades culturales que el universo de la comunicación hacía circular en lugar de las cosas. Nosotros hablamos comúnmente de una cosa que se llama /Alfa Centauri/, pero nunca hemos tenido experiencia de ella. Con algún aparato extraño un astrónomo ha tenido alguna vez experiencia de ella. Nosotros únicamente conocemos una unidad cultural que se nos ha comunicado mediante palabras, dibujos u otros medios" (Eco 1991:109-110).

${ }^{11}$ Un análisis más extenso de las representaciones alrededor de los eclipses está publicado en "La noche diurna: mitología de los eclipses" en Jesús Jáuregui, María Eugenia Olavarría y Víctor Franco Pellotier coords., Cultura y comunicación. Edmund Leach in memoriam, UAM-CIESAS, México, 1996, págs. 273-287 
sociales; por lo que el estrépito que se produce durante los eclipses tiene su correlato ritual en la costumbre de la cencerrada ${ }^{12}$. Esta identificación del papel del ruido en ocasión de la disyunción, por intromisión de un tercer elemento, de términos que en situaciones normales van apareados -cielo y tierra, sol y luna, esposos virtuales- explica por qué el estrépito no es tanto para ahuyentar al monstruo devorador del astro, sino para "llenar simbólicamente el vacío abierto por la captación" (Lévi-Strauss 1968:290).

En este sentido, el eclipse se presenta también como representación del incesto de sol y luna:

"Si el día y la noche, la conjunción y la disyunción, estuvieran demasiado cerca, se asistiría al incesto de sol y luna, a los eclipses, a la subversión de la periodicidad cotidiana. A la inversa, si el día y la noche, la conjunción y la disyunción, estuvieran demasiado apartados, el resultado sería el dia perpetuo o absoluto, o la noche perpetua o absoluta o un divorcio de luz y oscuridad" (Lévi-Strauss 1983:172).

Como otra forma de articulación entre el orden cósmico y el estacional, el ritual del estrépito también tiene lugar para señalar la modificación del orden estacional; a causa de los cambios que los eclipses producen en los ciclos estacionales agrícolas, no se puede sembrar ningún tipo de semilla en los días cercanos al fenómeno. Cuando tiene lugar uno de estos acontecimientos, se produce un desfasamiento de la luna y de las estaciones del año con respecto el ciclo anual, no hay correspondencia de las estaciones a partir del inicio del año hasta el día del eclipse y tampoco de las fases del satélite con respecto el inicio del mes, lo cual impide la correcta aplicación del calendario agrícola lo que produce, al igual que las uniones conyugales anómalas, infertilidad.

${ }^{12}$ Esta práctica consiste en que la comunidad entera provoca un gran ruido con cacerolas y trastos al frente de la morada de parejas recién casadas que representan una anomalía de las reglas de alianza. Se sancionan los matrimonios entre individuos que, a pesar de estar naturalmente separados entre sí ya sea por la edad, el estado civil, la conducta durante el celibato, o la posición social, se unen por afinidad. Estas alianzas anómalas provocan que un elemento dentro del ciclo del intercambio matrimonial sea dejado fuera (el cónyuge preferencial) mientras que dos elementos asimétricos se unen peligrosamente. 
Asimismo, entre las relaciones que este conjunto de creencias evoca, entre el plano cosmológico y el plano social, está presente la vinculación de los fenómenos astronómicos y las características de nacimiento. Lévi-Strauss (1983) establece la relación existente entre las características de nacimiento con los fenómenos meteorológicos: los mitos sobre el origen del labio leporino, o 'pico de liebre' y de la gemelidad, refieren que estas características se producen cuando el personaje recibe en el cuerpo una fisión, que le provoca la hendidura propia de esta deformidad.

Ahora bien, si los gemelos son resultado de un niño, embrión o animal escindidos o en vía de serlo, los mitos atestiguan que los gemelos son en sí mismos hendedores: a los gemelos concebidos implícitamente como "divididos", los mitos oponen el anti-gemelo que es en sí mismo un divisor ${ }^{13}$. La gemela que en algunas versiones yaquis traduce las profecias del árbol parlante, finalmente es quien divide a su pueblo, el suré ${ }^{14}$, y son los hijos gemelos del Diablo quienes realizan la disyunción del mundo social de las fiestas del mundo natural del bwiya toli, amo de los bienes culturales (Olavarría 1989). Cito la creencia yaqui en el sentido de que el nacimiento de gemelos se explica porque la mujer encinta "anduvo por el monte", por lo que uno de los gemelos, el que tiene el remolino de cabello en la cabeza, proviene del huya aniya y por lo tanto, tiene poder.

Existe, por otra parte, una clara asociación del desorden cosmológico con la enfermedad, la epidemia producto del eclipse parece ser, según Manrique

${ }^{13}$ Al escapar del cuerpo de su madre partiéndola en dos, Quetzalcóatl provoca la muerte de su madre. Otros mitos explican por qué uno de los gemelos es hijo del rayo, dado que éste tiene la capacidad de partir en dos.

${ }^{14}$ Cabe recordar que los surem que no aceptaron el bautizo se convirtieron en hormigas y que el nombre de la divisora es traducido como Abeja encantada. Las hormigas aparecen en los mitos como uno de los operadores lógicos por excelencia, no sólo se presentan como gemelas -escindidas- y como divisoras (a través de los rayos), sino también como autodivisoras, pues su cuerpo parece estar a punto de partirse en dos a la altura de la cintura. (Ver figura 3.33 "Los operadores binarios" en Lévi-Strauss, El hombre desnudo, 1983:504) 
(1991) una creencia netamente europea, como también el temor de venideros cataclismos, hambruna, la muerte de los señores u otros acontecimientos considerados negativos.

Este temor pudo haber tenido como una de sus bases el libro del Apocalipsis: "El sol se puso tan negro como vestido de luto, la luna toda se volvió como sangre". No obstante, esta representación apocalíptica encontró su correlato en las ideas nativas sobre la enfermedad y el desorden producto de los eclipses.

Cómo se construye y cómo se presenta este conjunto de creencias, que parece ramificarse hasta el infinito, evoca un árbol asociativo análogo al modelo semántico reformulado de Eco:

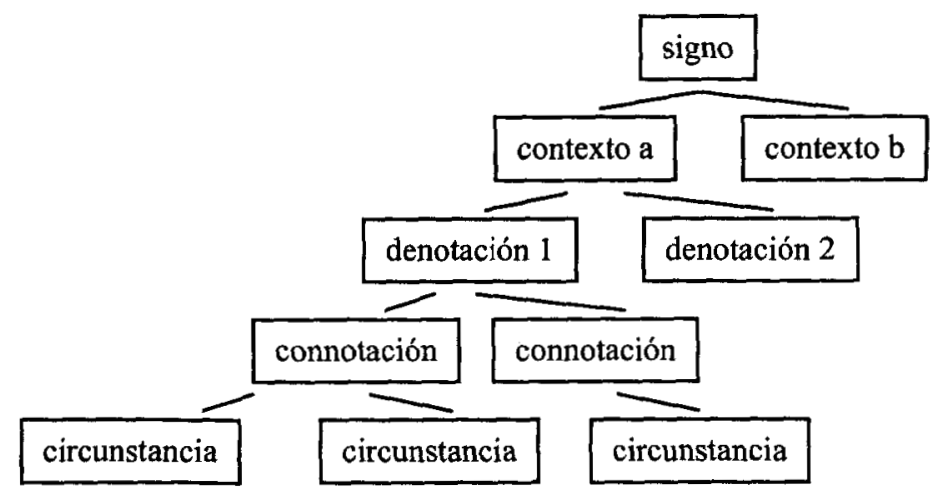

Basado en Eco 1991:181

Así, vemos cómo un nivel denotativo puede llevar a múltiples niveles connotativos, hasta llegar a constituir una metasemiótica. O bien, en términos de Pierce, a una semiosis infinita. Este modelo semántico ilustra la manera en que se articula el conjunto de contextos alrededor de este fenómeno astronómico $\mathrm{y}$ en él encuentran su posición las diferentes versiones recopiladas. En este árbol están presentes al menos tres contextos, que llamamos provisionalmente, científico, tradicional y sincrético ${ }^{15}$. En cada uno

15 Conviene aclarar que un modelo de esta naturaleza es un "artificio hipotético y transitorio establecido con el fin de explicar determinados mensajes, una hipótesis de trabajo elaborada para controlar el ambiente semántico inmediato de una unidad de 
de ellos está presente una serie de unidades de información regulada por leyes combinatorias internas 0 , sistema sintáctico; la serie de nociones o de contenidos de una posible comunicación, o sistema semántico; así como las posibles respuestas de comportamiento o pragmática por parte del destinatario. La regla que los asocia es el código (s-código o sistema-código) que se presenta en distintos niveles como el cosmológico, el de salud-enfermedad, el estacional (Eco 1991:63-65).

Los contextos tradicional y sincrético están desarrollados narrativamente, mientras que el contexto científico está referido a una denotación. Esta distinción queda establecida por el tipo de lenguaje que emplea cada uno de los códigos.

Retomo la discusión ${ }^{16}$ en torno a la identificación de, por un lado, un tipo de lenguaje asociado con la ciencia, que emplea elementos que presentan cierta univocidad y, por otro lado, el lenguaje de símbolos, polivalente, metafórico y hasta cierto punto motivado por la analogía. En el contexto científico, propio de los especialistas, impera un lenguaje denotado que trabaja con 'constructos', cuya finalidad es la de alcanzar la demostración al acercarse a una 'realidad objetiva'. Su propósito es hacer juicios de verdad o falsedad sobre una realidad percibida, sobre la que se impone un código gramaticalizado. Este tipo de lenguaje gramaticalizado es fundamentalmente normativo y unívoco, evoca un sistema de reglas cuyo cumplimiento garantiza la correción. Mientras que, por su parte, los contextos tradicionales y sincréticos apelan a una cultura

contenido determinada" (Eco 1991:200). Un árbol componencial que tome en cuenta todos los contextos y las circunstancias sólo es posible si existiera un 'Sistema Semántico Global', por lo que en este caso se identifica un ámbito cultural y un universo de discurso preciso.

16 Otros modelos alrededor de lo mismo: René Alleau (1989)afirma que el sistema científico, es un sistema de 'signos' el cual se caracteriza por ser un elemento arbitrario y convencional, idéntico a sí mismo y univalente; frente al 'símbolo' que implica una semejanza, una relación analógica y es polivalente. Por otro lado Edmund Leach (1981) identifica el signo con el tipo de relación metonímica, de contigüidad, o sintagmática, al unir dos elementos del mismo contexto; mientras que el símbolo es fundamentalmente paradigmático o metafórico al unir elementos de distinto contexto. 
textualizada, a un repertorio de ejemplos o modelos de comportamiento. ${ }^{17}$

Esta diferencia se basa en el énfasis que cada uno de los contextos otorga a uno u otro aspecto: presentan en común el hecho de que el conocimiento reservado a los especialistas - quienes conocen las causas precisas y pueden predecir con toda exactitud la ocurrencia del evento- es preferentemente 'gramaticalizado' y distinto al de otros sectores que - al desconocer las reglas del manual- confieren connotaciones y abren con ello abanicos de posibilidades semánticas. Pero esta distinción no puede ser simplista:

"Porque una sociedad científica resulta estar profundamente gramaticalizada sólo en el ámbito conceptual (sistemas científicos, clasificaciones, categorizaciones filosóficas), mientras que al nivel de los comportamientos parece, en cambio, característico de las sociedades más desarrolladas que se refieren a masas de textos hipocodificados, a modelos de tolerancia, a reglas muy abiertas; por el contrario, es típico de las sociedades primitivas que tengan comportamientos rituales y de etiqueta mucho más gramaticalizados que los nuestros" (Eco 1991:218).

En este momento de la discusión, una definición alternativa de signo, no como elemento cerrado en sí mismo, sino como 'función semiótica' -tal como propone Eco- se presenta como la más adecuada para dar cuenta de las diferencias y las relaciones entre los tipos lenguajes mencionados.

Así resulta que, en el contexto de tipo científico, el fenómeno del eclipse presenta una denotación primaria, mientras que si el contexto es el del habla popular o 'común' se obtiene una serie de connotaciones dispersas, muchas de las cuales probablemente sean las mismas, o cercanas, de la representación medieval, tradicional o judeocristiana. En este caso la gramática establece una dirección denotativa unívoca, pero su desconocimiento o su reconocimiento superficial conlleva a una textualización.

Las posibles circunstancias que aparecen al pie de este árbol corresponden a los distintos contextos etnográficos documentados o 'posibles', puesto que al

17 "Para Lotman la cultura gramaticalizada descansa en el Manual; la textualizada, en el Libro (Sagrado)" (Eco 1991:217). 
seguir una determinada 'ruta de lectura' se abre una nueva connotación o posibilidad semántica ${ }^{18}$.

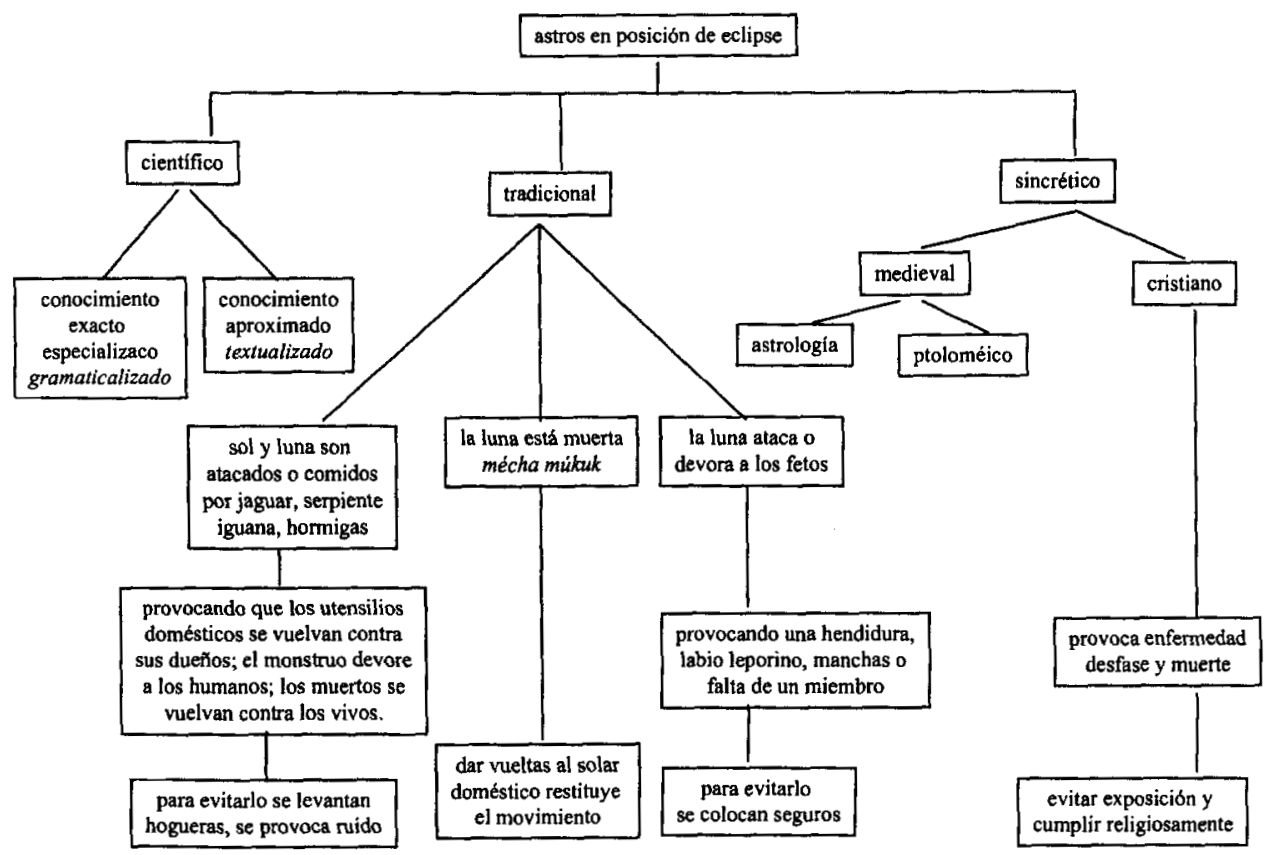

18 La interpretación de una circunstancia especifica, como el 'texto' de un sector de población mestiza compuesto por mujeres embarazadas del sur de la ciudad (entrevistadas en los días anteriores al eclipse solar total del 11 de julio de 1991 en la Ciudad de México) se explica por la convivencia de los tres códigos. La población entrevistada: a) acepta que el fenómeno astronómico presenciado tiene explicación en bases científicas (que algunas no podían verbalizar adecuadamente); b) desconoce los mitos que asocian a la luna con las liebres y el labio leporino; c) conoce, a través de la cadena tradicional oral, la posibilidad de que la exposición a un eclipse puede producir una malformación en los fetos d) actúa en consonancia con esto: colocando tijeras y espejos en el vientre o evitando la exposición al fenómeno (la justificación verbal era "por si acaso"), acompañado en algunos casos, de visitas a un templo católico. En este contexto, el discurso científico no entra en contradicción con la conducta ritual; ni la conducta ritual entra en contradicción con la ausencia de un texto narrativo, sino que se sustituye una gramática científica con una textualidad tradicional y sincrética. Este mecanismo constituye el "sincretismo" específico de esta situación, en el que la explicación científica abandona su terreno para convertirse en un elemento más del texto mítico. 
Así, en el ámbito de las creencias yaquis coexisten, al menos, las tres versiones identificadas como pertenecientes al contexto tradicional, más otra que viaja oblicuamente en dirección a la denotación científica. 
VI

SISTEMA DE LOS ACTORES RITUALES 


\section{PARENTESCO, PARENTESCO RITUAL Y RITUALES LAICOS}

En julio de 1996, cuando llegó el Güero, un joven de 15 años, a la casa de doña Clara, ella señaló que "el pobrecito no tenía padrinos", pero que ya había tomado las providencias para conseguirle quien lo acompañara en su graduación de la Telesecundaria de la Loma de Guamúchil. Ese año egresaron de tercero de secundaria cinco niñas y nueve niños originarios de Loma de Guamúchil y rancherías cercanas, aunque su promedio de edad supera al correspondiente en zonas urbanas, este fin de curso se considera un hecho celebrativo y que marca la posibilidad de que ingresen a la preparatoria de Vícam.

Desde hace tres años que egresó la primera generación de ese poblado, se repite este evento, sin embargo lo que convirtió en especial este ciclo fue el conflicto generado entre las maestras de la escuela, no yaquis, que se oponían a la organización de una fiesta de graduación y los padres y parientes de los jóvenes, prácticamente la totalidad del pueblo, quienes no podían imaginar la falta de una fiesta conmemorativa. Frente al argumento de las profesoras que aludía a la prohibición por parte de la Secretaría de Educación Pública de participar en los festejos de fin de cursos, la comunidad sentenciaba que se trata ya de "una tradición", puesto "es la manera que se sepa que ya acabaron la secundaria"1.

El clima generado por esta situación se reflejaba en continuos ires y venires de una a otra casa por parte de las "doñas", comentando las actitudes de las maestras y la firmeza de su decisión de no abandonar la oportunidad de

${ }^{1}$ En la zona yaqui existe educación formal desde el nivel preescolar hasta el bachillerato, así como capacitación técnica agropecuaria. La educación formal se imparte a través de los sistemas federal y bilingüe o indígena de la Secretaría de Educación Pública. La enseñanza bilingüe opera únicamente en las escuelas albergue en los niveles preescolar y primaria. En los poblados con mayor número de habitantes como Vícam Estación y Potam hay escuelas de los dos sistemas, pero en otros sólo opera el sistema bilingüe con escuelas unitarias. Cuentan con primaria albergue los poblados de Vícam Estación, Pótam, Loma de Bácum, Aguacaliente y Cárdenas. Los programas de estudio son iguales a los de las escuelas federales y se utilizan los libros de texto gratuitos de la SEP y las clases pueden ser en yaqui o en español, dependiendo del número de hablantes de la lengua materna. 
festejar a sus muchachos. En efecto, la comunidad se salió con la suya y a pesar de que el viernes 5 de julio se hizo la entrega de certificados, el sábado 6 alrededor de las seis de la tarde, se reunieron a celebrar una comida para los padrinos y madrinas coronada con "un baile con conjunto".

Resulta claro que lo importante para las familias yaquis era el establecimiento de una relación de padrinazgo, ya que sin ella - y el festejo correspondienteel hecho en sí de la graduación carecía de sentido. "Para que se sepa", esto es, para que la graduación en sí sea un hecho significativo, deben seleccionarse padrinos, intercambiar obsequios, participar de una comida especial y bailar acompañados de un conjunto musical.

Aún tratándose de un baile, evento profano y no una fiesta sagrada, la naturaleza de este acontecimiento evocó una de las características del sistema ritual de las comunidades yaquis: la necesidad de incorporar en un evento de carácter laico el esquema tradicional del parentesco ritual. El sistema escolar, reciente en el nivel de secundaria, ya se encuentra ajustado a las prácticas y creencias del padrinazgo y compadrazgo yaquis, lo cual implica que lejos de permanecer como un injerto laico al interior del sistema ritual, ha pasado a formar parte de éste como un auténtico rito de paso.

De esta manera los procesos de padrinazgo y compadrazgo se presentan como una estrategia poderosa. Además de haber funcionado - en su tiempo-como el vínculo mediante el cual las desmembradas comunidades yaquis de la diáspora alcanzaron cierta unidad (Spicer 1980) y como una de las prácticas inherentes al sistema de mandas y promesas (Figueroa 1994), el parentesco ritual en la actualidad mantiene una solidez que contrasta con la flexibilidad del sistema de alianza.

Este último se caracteriza por la ausencia de prescripciones matrimoniales de tipo elemental, por lo que las prohibiciones recaen sobre los consanguíneos y compadres. La tradición impone que ambas parentelas, tanto la del novio como de la novia, establezcan un convenio e intercambien contraprestaciones previas a la ceremonia que en la mayoría de los matrimonios se realiza de acuerdo a las normas de la religión católica; sin embargo éste no es requisito indispensable para la legitimación de la progenie. La unión libre es frecuente, al igual que la separación de los cónyuges, tal como queda retratado en las reconstrucciones biográficas de Jane Holden Kelley (1982). 
En los pueblos sureños del territorio tradicional yaqui son comunes los matrimonios y uniones maritales mixtos entre mestizos y yoremes, así como la articulación de no sólo dos sistemas parentales sino de la creación efectiva de un sistema nuevo que, no sin contradicciones y ajustes permanentes, crece y reproduce un singular sentido de la vida y del ser sí mismo. Por otra parte, tanto la unidad doméstica como las sociedades ceremoniales, civiles y militares funcionan como eficaces medios de transmisión, actualización y recreación de los aspectos culturales más importantes de los yoremes. Al interior de los grupos domésticos los adultos son los transmisores de las tradiciones de la comunidad a partir de la enseñanza, en primer término, de la lengua materna. El cuidado de los niños está a cargo complementariamente de la nana (abuela) y de los padres y el tipo de socialización está determinado por el género. La educación de ambos sexos se complementa con la instrucción escolar y la participación en fiestas y ceremonias tradicionales. En términos generales, puede afirmarse que la educación formal se supedita a la no formal, ya que existe consenso en que la asistencia a una celebración ritual es más importante que a la escuela ${ }^{2}$.

Los antecedentes de este sistema de alianza de tipo complejo no han sido completamente identificados, autores como Ralph Beals (1945) sugiere que durante el período pre-jesuita prevalecía la existencia de grupos de filiación unilineal entre grupos que denomina vagamente como 'cahítas'. Sin embargo, actualmente el parentesco se reconoce por ambos lados y no existen leyes de exogamia entre grupos de descendencia.

El sistema terminológico es de tipo yumano y presenta similitudes con los sistemas ópata, tepehuán y tarahumara del Norte de México, tales como la diferenciación de los parientes de acuerdo al sexo del hablante y la

${ }^{2}$ Es a través de los cargos o mandas que las niñas se incorporan al grupo de la Iglesia, con la finalidad de llegar a ser cantoras, su instrucción estará a cargo del maestro litúrgico y de las cantoras de mayor edad, y desde pequeñas deberán estar presentes en todas las celebraciones de carácter religioso para repetir los coros y alabanzas en latín que se transmiten oralmente desde el siglo XVII. Igualmente, los niños que descubren a temprana edad su vocación para la danza - Venado, Pascola o Coyote- se incorporan a la actividad ritual o bien como obligación por un voto de sus padres se adscriben como Malinche en la tropa de Matachines. 
importancia de la distinción de la edad relativa, sobre todo en la primera generación ascendente (Passim, H. 1946).

En el Valle, el tipo de alojamiento tradicional se compone de una o dos piezas, que varían su función de acuerdo a la temporada del año, en verano los cuartos permanecen como bodegas y se prefiere dormir en catres colocados en la enramada; durante el invierno se convierten en dormitorios. El centro de reunión familiar y el sitio donde se recibe a las visitas es la enramada (cobertizo hecho de ramas) que cobija la cocina donde se encuentra el fogón, la mesa y en ocasiones la estufa de gas. El material dominante en estas casas es el carrizo y mezquite enjarrado con barro tanto en muros como en techos, dejando uno de los muros sin enjarrar a fin de lograr ventilación cruzada cerca de los espacios destinados a la preparación de los alimentos. La estructura es de horcones de mezquite plantados en el suelo y ramas verticales y horizontales de este árbol sujetas con lazos. En general, sólo hay una puerta sin ventanas o con ventanas pequeñas y pisos de tierra. La mayoría de las casas yaquis tiene además un patio adyacente para diferentes actividades, como la cría de aves domésticas y ganado, la preparación de carne seca, pequeñas hortalizas y el entretenimiento de los niños. En el extremo opuesto del patio instalan letrinas construidas con las mismas características que sus viviendas, pero sin enjarre, y junto a ellas, y del mismo material, el espacio destinado al aseo personal. El diseño y orientación de las casas es una técnica tradicional que responde adecuadamente a las condiciones climatológicas de la región, característica que no comparten las casas de los mestizos. Aunque predomina el tipo de vivienda tradicional, se encuentran habitaciones construidas con materiales modernos - tabique - principalmente en los nuevos asentamientos como los poblados pesqueros.

El mobiliario es variado y depende de las posibilidades económicas de las familias, muchas de ellas cuentan con aparatos electrodomésticos y es similar al de la población mestiza, lo distintivo de los hogares yaquis son los petates, ollas de barro, utensilios y catres de madera y el fogón. Este se compone de un brasero de barro colocado sobre una horquilla tridente. Una casa de estas características la construye un jefe de familia yaqui con ayuda de sus familiares y amigos. Todas cuentan con agua intradomiciliaria y sólo muy pocas no tienen energía eléctrica. 
La unidad básica de residencia es el ho'akame o solar, concepto que denota una agrupación de parientes que cohabitan un conjunto delimitado de una 0 dos viviendas. No existe una regla de residencia fija, por lo que tanto los descendientes de un hombre como de una mujer pueden cohabitar el 'solar'. Sin embargo, la autoridad recae en el varón adulto de mayor edad productiva. El papel de las mujeres no es subordinado, pues además de participar en la toma de decisiones que atañen al grupo en su conjunto, son comunes los grupos domésticos articulados en torno a la figura de una mujer. Debido al incremento reciente de madres solteras yaquis, la matrilocalidad es común, aunque la regla vigente para la situación de matrimonio es la patrivirilocalidad. No es raro el tipo de residencia neolocal, ya sea que la vivienda para la nueva pareja sea construida en tierras de la familia del varón, prestada o rentada. A la muerte del jefe de familia es el individuo de mayor edad quien decide sobre el destino del ho'akame en su conjunto, por lo que no hay una asignación individual de las tierras o bienes del grupo doméstico ${ }^{3}$.

Las relaciones entre estas unidades domésticas son amplias y los lazos que las unen son numerosos, intrincados y en ocasiones, laberínticos. No obstante, la relación que predomina es la del parentesco ritual, puesto que el apelativo natural entre dos adultos vecinos es el de comai y compai.

Conviene enfatizar entonces el hecho de que las relaciones de parentesco ritual son muy significativas para los yaquis, tanto que el etnógrafo clásico de esta etnia, E.H. Spicer dedica extensos capítulos al tema, no así autores contemporáneos. La conducta entre compadres está, como ya se mencionó, más formalizada que la conducta entre aliados, el "usted" entre compadres y entre ahijados y padrinos (como también de hijos a padres) constituye un precepto. El incesto más penado es sin duda en el que intervienen compadres ${ }^{4}$, es decir todos aquéllos que caen dentro de la categoría determinada por la siguiente terminología:

3 El CIAD reporta que "El $57.8 \%$ corresponde a familias extensas. Mientras que el promedio de miembros para la familia nuclear es de 5, para la familia extensa es de 8.8. El promedio global para la Tribu es de 7.2 miembros por familia, índice muy superior al promedio estatal, que registra 4.75" (Valencia y Wong 1995:28)

4 Tanto los mitos como las creencias confirman este precepto de manera explícita (ver capítulọ IV). 


\begin{tabular}{|c|l|}
\hline padrino & nino, bato'achai, paino \\
\hline madrina & nina, bato'ai?, maina \\
\hline ahijado & bato'usi \\
\hline ahijada & bato'mala \\
\hline compadre & compai \\
\hline comadre & comai \\
\hline
\end{tabular}

También hay que señalar que los términos compadre y comadre se extienden a los padres y, en ocasiones, abuelos de los padrinos y de los padres del ahijado, a quienes se les nombra como "compadres de respeto", a diferencia de los primeros, a quienes se les designa como "compadres de pila".

La selección de los compadres no sigue una regla fija, ya que puede tratarse de parientes o no, si bien la tendencia es a elegir a dos individuos ajenos al núcleo familiar. Impera la ley que los compadres no pueden formar pareja. Esta regla, que se mantiene de manera explícita (si bien tuve conocimiento de excepciones al tratarse de ritos de menor importancia) es la de que los padrinos no deben estar unidos maritalmente. Es decir, que cada uno puede estar casado por su lado, pero no entre sí. Una respuesta exegética a la causa de esta prohibición es que "los casados no se respetan". No obstante que son pocas las parejas que se casan mediante el rito católico y cada vez menos aún las que celebran la ceremonia al estilo tradicional, aquéllas que cohabitan son consideradas como matrimonio $y$, por tanto, también entran en la categoría prohibida.

E1 compromiso de asistir como padrinos a un rito tiene como preámbulo el que los padres del niño, joven o iniciado acude a la casa de la persona elegida acompañados de sus familiares más cercanos y hacen la petición formalizada llevando un obsequio consistente en comida o flores. A partir de ese momento comienzan a tratarse de comai y compai. El negarse es prácticamente impensable ya que incluso, si la persona en cuestión no se encuentra en ese momento en el hogar, sus padres, abuelos o quien se encuentre tiene la obligación moral de aceptar. En primera instancia se busca el primer padrino del mismo sexo que el ahijado, para que una vez que haya aceptado, sea él o ella quien busque a su acompañante en el ritual. Se sobreentiende que no 
puede ir con su esposo o esposa, y a pesar de que algún sacerdote católico ha tratado de convencerlos de la conveniencia de que así sea, los yoremes prefieren continuar con su tradición. En ocasiones los padres eligen a ambos padrinos desde el principio, pero se sigue conservando la norma de que no deben estar casados.

Con base en el tipo de ritos que los generan, existen en las comunidades yaquis dos tipos de parentesco ritual: el que se establece a partir del bautizo, matrimonio, muerte ${ }^{5}$ por un lado; y aquél que lo hace a partir de las iniciaciones y bendiciones, los cuales sólo superficialmente corresponden a la tipología de Pitt-Rivers (1975). No existe, en términos estrictos, una diferencia de estatus entre ambos, si bien la desobediencia a la regla referida que yo presencié se rompió en ocasión de una "persignada de angelito" y no en ocasión de un bautizo y cuando los padrinos eran mestizos y no yoremes. El segundo conjunto de ritos, que se refiere al ingreso de un individuo como miembro de una de las sociedades ceremoniales, y los que tienen que ver con la sacralización de una capilla, una imagen o un objeto, tiene un papel muy importante en el sistema de parentesco ritual, el ingreso de un individuo al grupo de la iglesia, al kohtumbre, a la cofradía militar, a la autoridad civil o como fiestero, está marcado por el compromiso de los involucrados como ahijados y padrinos, creando un lazo de por vida. ${ }^{6}$

Las características de las iniciaciones, así como del rito mortuorio, ya fueron descritas y analizadas en el capítulo IV, por lo que aquí nos referiremos a la relación ahijado-padrino que se presenta como la más significativa, aquélla del rito fúnebre frente al otro extremo del eje vital: el bautizo.

${ }^{5}$ No obstante que los sacramentos reconocidos por la iglesia católica son siete, algunos de ellos no son practicados normalmente en territorio yaqui, por ejemplo, la confirmación requiere de la presencia de un "papa" (obispo), que en raras ocasiones asiste a esas comunidades. Asimismo, el rito de muerte yaqui no corresponde a la extremaunción del catolicismo.

${ }^{6}$ Se habla con frecuencia de que tanto ahijados como padrinos de un miembro de los yau'ram, crecen juntos y el lazo dura hasta la muerte. $O$ bien hay promesas que se heredan de padre a hijo, aún cuando éste la continúe en un grupo ceremonial distinto "una promesa es una promesa y no importa en donde la hagas". Para un padrino o madrina de un cabito, que suelen ser los tres niños menores de quince años, es un importante esfuerzo formativo el tener que acompañar al ahijado en sus actividades rituales, ya sea preparándole la comida y llevándosela a la iglesia, donde están acuartelados durante la Semana Santa. 
Aunque poco frecuente, existe una tradición que consiste en que uno de los padrinos "le echa agua" al infante acompañado por sus padres y familiares, mientras el maestro litúrgico y las cantoras oran. Cabe señalar que en esta práctica prevalece la imposición del nombre sobre cualquier otro significado religioso. Este rito se realiza en casa del padrino o madrina y es una costumbre análoga a otras presentes en grupos pertenecientes a la familia lingüística utoazteca $^{7}$

Se diferencia explícitamente esta ceremonia frente al bautizo católico, ya que la primera se realiza frente a enfermedades o contingencias como un recurso precautorio. Para un niño de las comunidades yaquis, el momento del bautizo llega cuando un sacerdote asiste al poblado en ocasión de celebrar la misa con motivo de la fiesta patronal. En este caso, impone el sacramento a los niños sin mayores preámbulos en cuanto a la indumentaria o el festejo, pero sí en lo referente a la selección de los padrinos. Otra posibilidad es que los padres y padrinos se desplacen a Vícam Pueblo, donde reside el sacerdote, para efectuar el bautizo de manera más organizada y en una fecha previamente establecida.

La norma es que los padrinos deben hacer un regalo a su ahijado, el cual, de alguna manera, es compensado por la comida que ofrecen los padres en su casa a la que se conoce como bolo. La realización del banquete puede posponerse cuando no se cuenta con recursos económicos. Al término del bolo, la persona de mayor edad de la familia del bautizado, o un "abogado", pronuncia un discurso solemne que tiene como principal motivo el agradecimiento a los padrinos y a los presentes.

El lazo así establecido entre padres y padrinos no se termina en ese momento, sino que éstos adquieren la obligación de que los próximos dos hijos nacidos también deberán ser bautizados por el hombre y la mujer que apadrinó al primogénito. Cuando se han llevado a cabo tres bautizos de tres hermanos, tiene lugar una ceremonia de agradecimiento para la que ya se ha construido - como es el caso del resto de las fiestas yaquis- una enramada de carrizo en

${ }^{7} \mathrm{La}$ información referente al rito bautismal está basada en la descripción de Mendoza Ontiveros, Marivel, El sistema de compadrazgo en las comunidades yaquis del estado de Sonora, Tesis de licenciatura en Antropología Social, UAM, 1992 
el portal de la casa y se ha plantado una cruz de madera. Se repite el "bolo", pero en esta ocasión se trata de un evento más concurrido, así como de una retribución más copiosa para los padrinos. El discurso del "abogado" frente a la "cruz del perdón" está acompañado por un recorrido por la cruz, conti vo'o, y un triple saludo entre padres y padrinos, en el que estos últimos entregan simbólicamente los ahijados a sus padres.

La aparente dualidad del primer rito de paso en la vida de un yoreme - la ceremonia tradicional y el bautizo católico - no representa mayor problema al interior del sistema social y cultural, ambas ceremonias son reconocidas, si bien la primera, como ya anotamos anteriormente, privilegia la imposición de nombre sobre cualquier otra significación. Tuve conocimiento de una práctica, que casi ya no se realiza, que consiste en la imposición de un "nombre volteado" a un niño cuyo nacimiento ha sido precedido por la muerte de uno o más de sus hermanos. Este nombre volteado o al revés, permanece en secreto y lo imponen los padrinos.

La importancia de la imposición del nombre, como aspecto privilegiado del 'bautizo' tradicional, también está presente, tal como ya lo mencioné, al término de la vida de yoreme. Cabe recordar que los padrinos de muerte ocho en total, entre quienes deben encontrarse los de bautizo - imponen al difunto cada uno dos nombres que lo acompañarán en su vida trascendente.

Esta relación entre los dos ritos de paso, que se sitúan en los polos vitales de un individuo, es la que interesa analizar a fin de articularla con el campo semántico afín, basado él también en un eje semántico que evoca la vida y la muerte: el ciclo ritual anual. Las relaciones entre los elementos que conforman ambos rituales en cuanto a sus secuencias, prohibiciones y prescripciones, prestaciones y contraprestaciones, así como de intensificación de los lazos de parentesco ritual, pueden sintetizarse como sigue: 


\begin{tabular}{|c|c|}
\hline BAUTIZO & MUERTE \\
\hline Una pareja & Cuatro parejas \\
\hline $\begin{array}{l}\text { es elegida libremente para el } \\
\text { primer bautizo }\end{array}$ & $\begin{array}{l}\text { una de ellas prescrita por haber } \\
\text { presidido un bautizo }\end{array}$ \\
\hline $\begin{array}{l}\text { está prescrita para tres bautizos } \\
\text { consecutivos }\end{array}$ & $\begin{array}{l}\text { si está muerta puede elegirse } \\
\text { libremente a otra pareja }\end{array}$ \\
\hline $\begin{array}{c}\text { extendiendo la relación hacia los } \\
\text { padres } \\
\text { (padrinos de respeto) }\end{array}$ & $\begin{array}{l}\text { que pueden ser los hijos de los } \\
\text { padrinos de bautizo }\end{array}$ \\
\hline impone el nombre a tres niños & impone el nombre a un muerto \\
\hline $\begin{array}{l}\text { en un rito que transcurre al cabo de } \\
\text { tres nacimientos } \\
\text { (periodo de tiempo biológico) }\end{array}$ & $\begin{array}{c}\text { en un rito que transcurre al cabo de } \\
\text { un año } \\
\text { (período de tiempo solar) }\end{array}$ \\
\hline recibe un "bolo" & da una fiesta "cabo de año" \\
\hline en casa de un niño & en casa de un difunto \\
\hline $\begin{array}{l}\text { para reconocerse como } \\
\text { padrino - ahijado }\end{array}$ & para reconocerse como compadres \\
\hline
\end{tabular}

Así tenemos que los ritos de paso que se sitúan en los extremos del eje vital el bautizo y el ritual mortuorio - refieren, a partir de los elementos contrarios que los enfrentan, la temática central del universo significativo que tiene como otra de sus expresiones el ciclo ritual anual que he venido desentrañando.

Los ritos de paso -bautizo, matrimonio, funeral-cabo de año-- están prohibidos durante el duelo y período sacrificial representado por la waehma. La alternancia waehma - wasuktia en el ciclo ritual, está asociada semánticamente con la oposición muerte vida, las dos relaciones parentales de tipo ritual, se sitúan igualmente en los dos polos de la vida individual: bautizo: vida :: funeral-cabo de año: muerte.

No obstante, una observación directa permite constatar que durante el período Cuaresmal sí se realizan dos tipos de iniciaciones que tienen que ver con el ingreso de un individuo al grupo de los fariseos o bien de los más jóvenes como angelitos o portadores de hábito. Éstas son: la "amarrada" a los fariseos para "persignarlos" el domingo de Pascua, descrita pormenorizadamente en el 
capítulo tercero, y la "persignada" de las niñas que se inician como angelitos ${ }^{8}$ y los niños y niñas a quienes se les impone el hábito son acompañados por sus padrinos durante el Jueves Santo. Justamente este hecho es la base de mi interpretación del significado del Sábado de Gloria como rito liminar, ya que esta jornada está consagrada precisamente a aquellos personajes que se sitúan en los intersticios del sistema, liminares por definición: los chapayekas y los angelitos; los extranjeros y los niños ${ }^{10}$.

Estos tres ritos, que se realizan en temporada sagrada, se oponen naturalmente a aquéllos que se llevan a efecto en el tiempo ordinario, tales como el ingreso al teopo ya'ura o grupo de la iglesia, al pahkome y a la autoridad militar. Cada uno tiene su particularidad en lo que se refiere al establecimiento de lazos parentales de compadrazgo y padrinazgo; sin embargo, el rasgo que los caracteriza es que el padrino siempre ocupa el puesto al que accede el ahijado, en lo que radica su carácter, hasta cierto punto, prescriptivo. Pero, por el otro lado, su relación no implica obligaciones sucesivas en este sentido para los padrinos. Mientras que en aquellas relaciones de compadrazgo establecidas durante la Cuaresma, la pareja de padrinos acompaña a su ahijado durante los tres años consecutivos que dura su relación.

Así, una joven que será "persignada" como cantora, tenanchi o kiyoste, tendrá como padrinos al propio Maehto y a la mujer de mayor edad que ocupe el cargo al que accederá, de acuerdo con la promesa efectuada con anterioridad por sus padres. Lo mismo ocurre en la milicia ya'ura.

${ }^{8}$ Los angelitos acompañan y protegen a Jesús y a la Virgen durante la Semana Santa y adquieren este estatus por una promesa hecha por sus padres. Los padrinos de los angelitos deben comprar la ropa, acompañar a los niños en las procesiones y en todos los actos relacionados con el cargo a lo largo de tres años consecutivos, al término de los cuales le colocan el rosario y el "paño cruzado".

${ }^{9}$ Como promesa a cambio de su bienestar, los padres de un niño enfermo se dirigen a la Virgen o al santo de su devoción y prometen vestir a su hijo con las características de su benefactor por un lapso de tres años. Los dos padrinos mandan confeccionar el hábito y la madrina se lo coloca frente al altar.

${ }^{10}$ Al morir, no sólo simbólicamente en el rito sino realmente, los niños son también angelitos y su funeral es distinto al de un adulto, su cuerpo se rodea de flores sewam y sí pueden acudir a bailar los pascolas. 


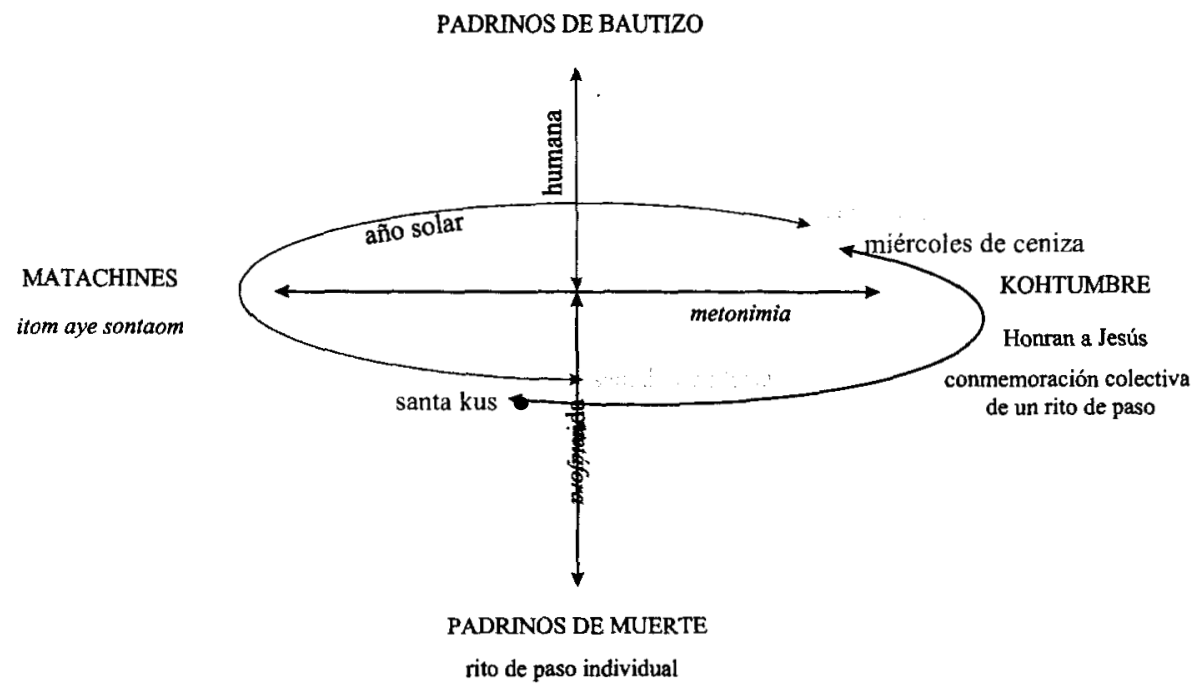

Los miembros del pahkome, responsables de las fiestas del wasuktia, "amarran" a sus sucesores colocándoles el rosario kusim y el paño azul o rojo, y convirtiéndose ellos mismos en compadres de sus herederos en deber y compromiso. Es inexistente la relación padrino-ahijado, no obstante, la elección de compañero o compañera opera con base en una regla análoga a la que gobierna la elección de padrinos: no debe mediar relación de alianza alguna.

Por tanto, alianza y parentesco ritual son dos campos excluyentes que refieren dos ámbitos significativos que deben permanecer diferenciados. Ya que si la presencia de tormentas en los funerales propicia la trasposición del campo semántico estacional (incesto imaginario) y la conjunción de sol y luna es metáfora de un incesto simbólico; entonces, evitar la confusión de los lazos de alianza y parentesco ritual tendrá como fin, conjurar el caos social. 
Así como la vida cotidiana está montada sobre una red de parientes, la vida ritual actúa sobre la base de la organización político - religiosa contemporánea yaqui, sustentada en los cinco conjuntos identificados, ya sea como grupos ceremoniales (Fabila 1949), cofradias (Gilbert 1985), autoridades (Spicer 1969) o como prefiero llamarlos aquí, con el término yaqui de ya'uram. Si bien la descripción etnográfica los ha tratado como cinco ámbitos aislados, mi perspectiva reconoce que, en la vida de los yoremes, éstos se presentan como distintas opciones para cumplir con su vocación ritual. Es común que un mismo varón adulto haya sido prometido como matachín y fariseo, y además, cumpla con un cargo de carácter civil. Pero no sólo en este sentido los cinco ya 'uram están relacionados, sobre todo los une el hecho de que sus miembros pasan por ritos de iniciación que los acercan, de una u otra manera, al polo de lo sagrado. La instauración de relaciones de parentesco ritual en cada una de las iniciaciones, convierten a los ya'uram en auténticos mecanismos de fortalecimiento del principio que estructura las relaciones sociales en los ocho pueblos.

$\mathrm{Si}$ bien, podría argumentarse, que la principal responsabilidad de las autoridades civiles, por ejemplo, es la relación político - administrativa con el gobierno municipal, estatal y federal, también es cierto que siempre están pendientes del respeto que se debe a los símbolos sagrados, sobre todo por parte de los ajenos a la etnia. Así, los cinco gobernadores o cobanaos, jerárquicamente organizados además del alawasin, se renuevan cada año en una ceremonia llevada a cabo los días 5 y 6 de enero, en cada uno de los ocho pueblos. Otra característica es que los cobanaos presiden las asambleas que se realizan cada domingo a las que asiste el pueblo y todos aquéllos que tengan alguna solicitud o asunto que les competa.

El cobanao ya'ura está complementado con la representación del consejo de ancianos, conformado en su mayoría por exgobernadores, conocido como pueblo Mayor o pueplum yo'hue y por un secretario, este órgano tiene, en muchas ocasiones, la última palabra ${ }^{11}$. El primer gobernador es el que tiene la

"No siempre hay consenso en torno a la elección de los cobanaos, como en 1989 cuando por primera vez se eligió a una persona menor de cuarenta años como cobanao en Loma de Guamúchil, confrontando así las tendencias más tradicionalistas de la etnia. 
máxima autoridad administrativa y política, además ocupa un lugar principal durante las ceremonias religiosas que en muchas ocasiones preside. El 6 de enero se lleva a cabo la ceremonia de cambio de gobernadores, fecha en la que se honra "a las naranjas" y con ello se marca el fin de las fiestas en honor al Niño Jesús.

Lo que originalmente fue un ejército de reserva, hoy día constituye la autoridad militar, una de cuyas funciones ceremoniales consiste en presidir las reuniones dominicales de los cobanaos con el pueblo y es la encargada de observar el orden y de ejecutar castigos en caso de perturbación o infracción de las reglas marcadas durante las fiestas. Su patrona es la Virgen de Guadalupe y la danza de los Coyotes su emblema. Para ser iniciado en este ya'ura es necesario haberse "prometido", y dado que no se trata, evidentemente, de un ejército regular, no existe movilidad en la jerarquía interna, pues si un miembro tiene un cargo de teniente por ejemplo, así continuará por haber sido persignado por un padrino con el mismo cargo. La mayor jerarquía la representa el capitán yo'hue, le sigue el teniente, el sargento, el cabo, los soldados, el banteo o alpes, y el tampaleo. Estas autoridades tradicionales paulatinamente han dejado en manos del poder judicial la impartición de justicia en los casos de infracciones graves; aunque la policía, en teoría, debe estar subordinada a las autoridades yaquis, en la práctica no resulta asi, lo cual ocasiona frecuentes fricciones.

Los fiesteros o pahkome tienen una reponsabilidad exclusivamente ritual: el cumplimiento del wasuktia en cada uno de los pueblos. A menudo tratados como una agrupación independiente, con base en sus funciones, puede afirmarse que el pahkome es parte integrante del teopo ya'ura. Su cargo dura un año, al cabo del cual se nombra o se "amarra" a un sucesor a quien se denomina compadre. La estructura de cada bando es la siguiente: capitán yo'hue, capitán segundo, alawasin y moro.

El teopo ya'ura, la autoridad religiosa, es el depositario del conocimiento de la liturgia y por ello está revestido de la máxima sacralidad, sólo comparable a la del kohtumbre. En un principio los maestros yo'hue y el temastian de cada pueblo eran los encargados de vigilar las pertenencias de la Misión y de apoyar al misionero en la enseñanza del catecismo, pero pronto se convirtieron en sus ayudantes en los oficios y, después del destierro de la Compañía de Jesús, quedaron como los encargados de llevar a cabo las 
prácticas religiosas. En la actualidad la autoridad religiosa está asegurada por dos hombres y una mujer: el maehto yo'hue maestro mayor; el temastian primer sacristán, y kiyohteis yo'hue, quienes se sitúan a la cabeza de una doble jerarquía: los miembros varones reconocen como máxima autoridad al maestro litúrgico o maehto yo'hue y las mujeres siguen las indicaciones de la kiyohteis yo'hue. El maestro asume la administración de la iglesia y es el encargado de conducir las oraciones pero no puede oficiar misa, por lo que de manera paralela a la organización religiosa yaqui, idealmente el sacerdote católico debe acudir cada domingo a cada pueblo. Puede afirmarse que actualmente se vive una crisis vocacional en lo que se refiere a los puestos de más alto rango, ya que algunos jóvenes abandonan o cambian su promesa al constatar que las tareas de este cargo son muy rígidas.

La jerarquía femenina está compuesta en primer término por el grupo de cantoras, las kiyohteis, encargadas del cuidado de los altares y de los templos, las tenanchis, jóvenes que portan las banderas. Categoría aparte forma los angelitos, niños y niñas que protagonizan el triunfo de las flores en la tercera "gloria" del Sábado Santo. Igualmente, forma parte del teopo ya'ura la tropa de Matachines o Soldados de la Virgen: cuerpo de danzantes constituido por un cobanao, quien es el matachín de mayor edad, el monaha yo'hue o monarca mayor quien conoce y dirige las coreografias, el Malinche, joven prometido para ocupar posteriormente el puesto de monaha, y la tropa. De suma importancia son los músicos - violín y guitarra- quienes accedieron, por medios oníricos, al don de la música otorgado por la Virgen.

Para ocupar un cargo en cualquiera de sus puestos, los padres ofrecen al niño en manda a temprana edad o aún antes del nacimiento o bien, en ocasiones, un mismo individuo hace la promesa y, en caso de ser joven, es colocado bajo la tutela del padrino para su instrucción en los deberes propios de su dignidad.

El conjunto de actividades que realiza a lo largo del año el teopo yau'ra puede agruparse en los siguientes: 1) el culto a Jesús, a cargo de los varones del grupo, que tiene lugar de enero a mayo, 2) el culto a la Virgen María, o Nuestra Madre, cuya responsabilidad recae en el grupo de la Iglesia en su conjunto y en la 'tropa' de Matachines cuya patrona es la Virgen, 3) asistir los funerales, novenarios, cabos de año y el Día de Muertos, 4) junto con la autoridad militar, presidir los oficios de la Virgen de Guadalupe, 5) participación en las fiestas anuales conmemorativas del santo patrón de cada 
uno de los pueblos, 6) presidir los ritos de paso como bautizos, casamientos y la iniciación de nuevos miembros en la cofradía, así como la confirmación de las autoridades civiles.

Como resulta evidente, con excepción de los matachines, éste es el único de los cinco ya'uram ${ }^{I 2}$ que participa a todo lo largo del año ritual, a diferencia de los que reparten su actividad en uno de los dos períodos del ciclo: el kohtumbre, representado por los soldados de Roma, ocupa en waehma el sitio de los cobanaos y la milicia. Los fiesteros interrumpen su participación en waehma, pero el teopo ya'ura la continúa.

Así, son aquellos personajes que se excluyen mutuamente - los matachines frente a los chapayekam, los fiesteros frente al kohtumbre - los que marcan el ritmo estacional, y por tanto, los que nos interesan desde el punto de vista de su significación más amplia. capítulo IV.

${ }^{12}$ El quinto yau'ra es el kohtumbre, descrito en el apartado correspondiente del 


\section{SINTAXIS DE LAS RELACIONES RITUALES}

Así, los dos ya'uram que marcan el ritmo estacional del ciclo ritual, son por un lado, el pahkome - responsable de los ritos de vida colectivos en tiempo ordinario y por el otro, el kohtumbre - responsable de la conmemoración colectiva de un rito de muerte a lo largo de la Cuaresma y Semana Santa.

En el nivel de los actores, la oposición más marcada, y por ende, la más explícita, es la que se instaura entre matachines y chapayekas. Entre ellos dos se libra el conflicto el Sábado de Gloria, en el que median las flores, y las fechas asociadas al término de su participación ritual - Candelaria y la Santa Cruz- imponen una perspectiva estacional.

En este apartado intento establecer la relación que esta oposición representa al interior del sistema de actores, así como el subsistema iconográfico implícito en la parafernalia que los distingue. Con este fin, y una vez reconocida la relación metonímica en el tiempo solar colectivo entre estos dos conjuntos de actores rituales, la segunda relación significativa es la que opera de acuerdo al carácter colectivo o individual de los ritos. En este sentido, y bajo las reglas que seguí en el análisis de la cosmología:

\begin{tabular}{|c|c|}
\hline 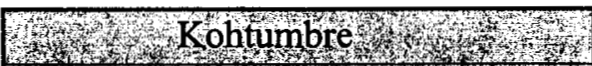 & Fiesteros \\
\hline Tepresentacion colectiva de huerte & ritos colectivos de vida \\
\hline HV & vida \\
\hline
\end{tabular}

Si el contenido semántico de la oposición metonímica matachines/fariseos empata con las nociones vida colectiva/muerte colectiva presentes tanto en los ritos colectivos de paso como en la conmemoración colectiva de la muerte; entonces el otro par significativo atañe a la relación metafórica entre vida individual/muerte individual: 


\begin{tabular}{|c|c|}
\hline ciclo vital individual & ciclo vital colectivo \\
\hline conmemoracion colectivaderito & $\begin{array}{c}\text { conmemoración de rito fúnebre } \\
\text { individual }\end{array}$ \\
\hline
\end{tabular}

cuyos principales actores son:

\begin{tabular}{|c|c|}
\hline Padrinos ritos de paso & Fiesteros \\
\hline 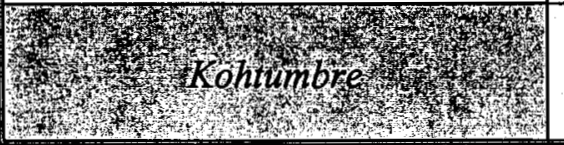 & Padrinos de muerte \\
\hline
\end{tabular}

Donde las relaciones verticales (1) y horizontales (2) son de carácter metafórico, y las diagonales (3) de contigüidad:

1) El pahkome se encarga de las fiestas que tienen lugar en el tiempo ordinario del ciclo vital comunitario, los padrinos de muerte "hacen la fiesta para un muerto". Los padrinos acompañan al individuo en sus crisis vitales, el kohtumbre está presente en la conmemoración de un rito de muerte.

2) El pahkome actda en los ritos de paso comunitarios y los padrinos en los individuales; así como los padrinos de muerte hacen significativa una muerte real y el kohtumbre hace real una muerte simbólica.

3) Desde el punto de vista del sintagma, el pahkome es sucesivo al kohtumbre en el nivel comunitario, tal como los padrinos de bautizo lo son a los de muerte, en el plano singular.

De esta manera, este sistema de cuatro elementos provee la base para la identificación de las variantes de relaciones de parentesco ritual: los fiesteros, cuatro hombres y cuatro mujeres, "amarran a sus compadres" al término de su período, sin mediar un ahijado; mientras que los miembros del kohtumbre son acompañados por sus padrinos en el momento crucial de su breve existencia 
de cuarenta días, enfatizando la relación de padrinazgo. Frente a este par opuesto compadrazgo/padrinazgo que representa los extremos de la vida y muerte comunitaria, los padrinos de un individuo están unidos a lo largo de su ciclo vital. Cabe recordar que los padrinos de bautizo son llamados en primera instancia para fungir como una pareja de las cuatro que se requieren como muka painos o padrinos de muerte, estableciendo así una especie de régimen de filiación paralela, que puede prolongarse hasta la siguiente generación (Héritier 1985).

De manera que el entramado social, de apariencia caótica de las relaciones de parentesco ritual, corresponde a un esquema como el siguiente:

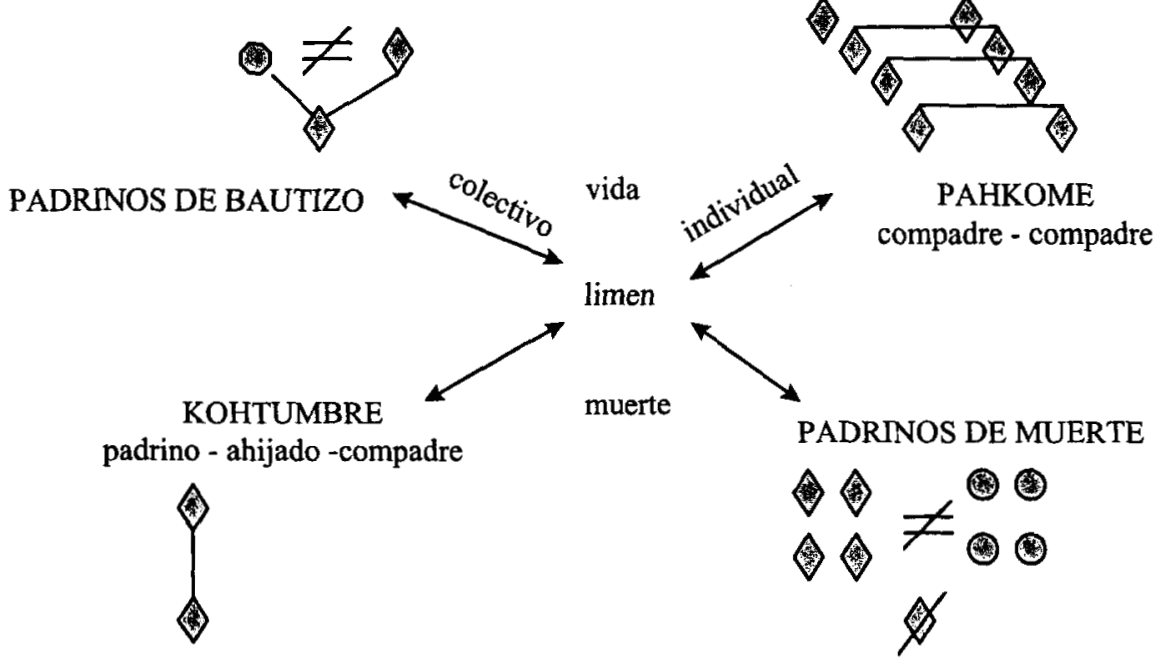

A su vez, este sistema remite a la cosmología cuya sintaxis se discutió en el capitulo quinto, y permite reconocer nuevas relaciones significativas. Si el eje cosmológico secciona el sistema ritual desde el punto de vista de su 
comunicación con los tres planos (verticales); se observa, a partir de la etnografia, que la ubicación diferencial de cada uno de los conjuntos de actores corresponde a las categorías espaciales (en el plano horizontal) que tienen que ver con su participación en los ritos que conllevan relaciones de parentesco ritual reales en los primeros cuatro términos y metafóricos en los segundos.

\begin{tabular}{|c|c|}
\hline $\begin{array}{l}\text { Fiestas del wasuktia } \\
\text { pahkome, matachines } \\
\text { iglesia, tebat }\end{array}$ & $\begin{array}{l}\text { ritos de paso individual } \\
\text { padrinos } \\
\text { casa-iglesia }\end{array}$ \\
\hline $\begin{array}{l}\text { funeral-cabo de año } \\
\text { padrinos de muerte } \\
\text { casa- cementerio }\end{array}$ & 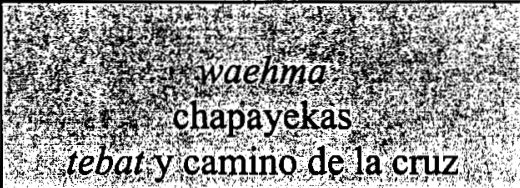 \\
\hline $\begin{array}{l}\text { fiestas del wasuktia } \\
\text { pascola y venado } \\
\text { enramada al este }\end{array}$ & $\begin{array}{c}\text { ritos de paso } \\
\text { yo'chivato, animalitos del } \\
\text { monte, choni } \\
\text { sierra }\end{array}$ \\
\hline $\begin{array}{l}\text { funeral-cabo de año } \\
\text { kurues } \\
\text { océano }\end{array}$ & 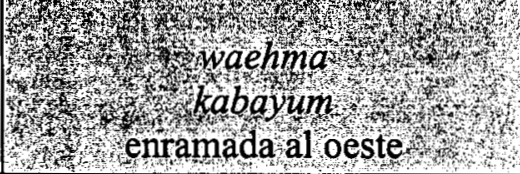 \\
\hline
\end{tabular}

1) El campo semántico de los dos primeros pares alude a los polos entre los que se desarrolla tanto la vida comunitaria (pahkome en ritos de paso colectivos y el kohtumbre) como la vida humana (ritos de paso y funeral-cabo de año). En términos del lenguaje situacional que los define, el discurso de la comunidad tiene como escenario la iglesia, el tebat y el camino de la cruz, el viaje del individuo es casa- iglesia- cementerio. Esta configuración, por su parte, sitúa la crisis vital de los chapayekas (antihumano-humano) como correlativa a la crisis de los neófitos (humano-iniciado). Sólo así se entiende el carácter original de los chapayekas: "los chapayekam vienen del norte, del 
extranjero, no son de aquí" y la valiosa intuición de Spicer por encontrar la respuesta a su naturaleza en la comparación con las katchinas hopi y zuni (1980:61-62).

Así, a partir de su identificación marginal en el sistema de posiciones, es que se logra discernir su carácter doblemente negativo: ya muertos en el ritual de iniciación, los chapayekam vuelven a morir ritualmente el Sábado de Gloria. Su campo de significación es doblemente negativo: son el yo muerto, ni lo uno ni lo otro, son el reconocimiento de ser uno y de ser dos al mismo tiempo. Su conversión, antes que negar, reafirma la novedad de la religión yaqui frente a su doble fuente. En consecuencia, su valoración es positiva, de ninguna manera los chapayekam son sólo penitentes, su participación ritual es de las más valoradas en términos de prestigio para la familia y el iniciado mismo.

"Un chapayeka guarda todas las cruces que llevó en su vida, cada rosario de cada Cuaresma se lo ponen de muerto y se los lleva todos. Mientras más tenga, con más honores es su funeral. Así se reconoce su trabajo"

2) Los dos pares de relaciones que completan el sistema se refieren a padrinos metafóricos, habitantes del huya aniya, que pueden o no ser personificados y cuya existencia onírica o imaginaria remite a la religión del monte. Están presentes tanto animales imaginarios como el masochoki, venado estrella, como hombres con nombre de animal, los kabayum, pasando por un hombrechivo yo'chivato y la kurues. Por su posición, queda claro que son parte intrínseca del sistema cultural, y que su significación más amplia viene dada por éste: 


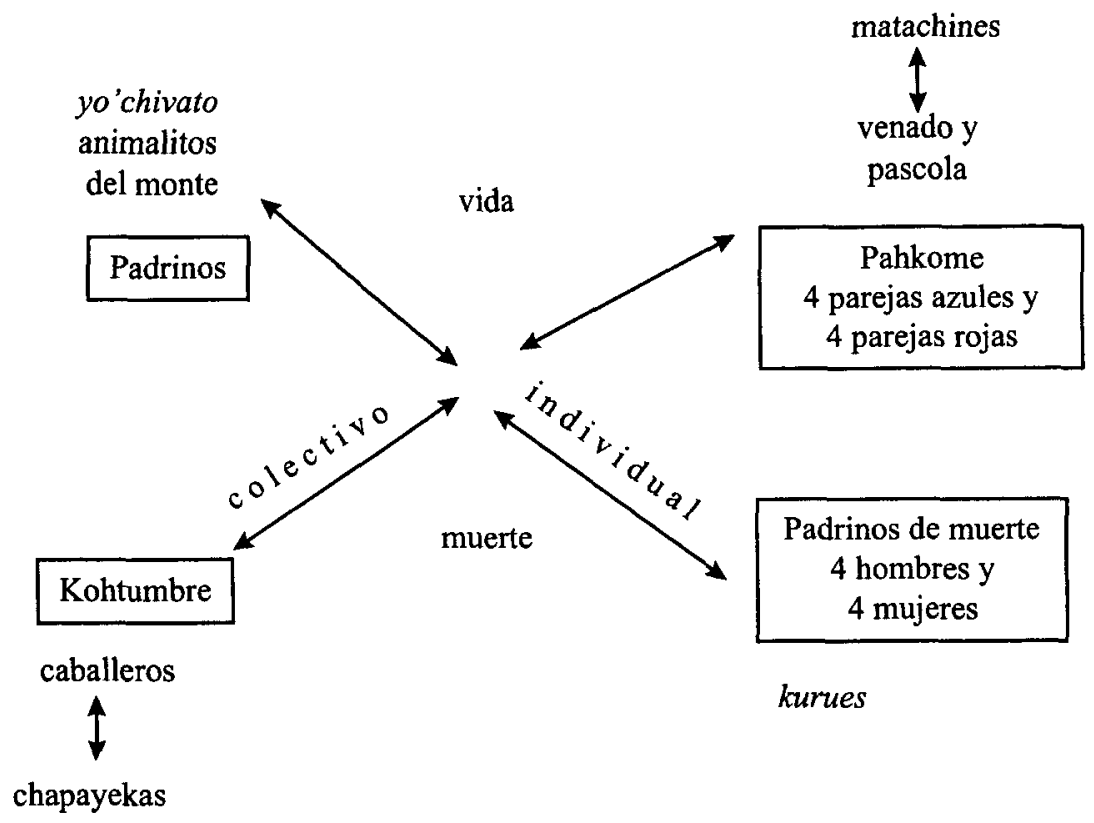

Las iniciaciones de los danzantes de pascola y venado siguen un procedimiento esotérico más o menos estereotipado: a partir de sueños con chivos y serpientes, y de experiencias que podrían calificarse de sueño lúcido, los jóvenes destinados a esa profesión establecen comunicación con los animalitos del monte o con el choni a partir de vigilias prolongadas en algún lugar de la sierra. Desde ese momento el pascola está unido a los animalitos del monte, éstos adornan su máscara y son personajes de los sones que acompañan su danza. La ubicación de los pascolas en la enramada este, confirma su asociación con "los yaquis broncos".

Y así como la sierra (este) nunca se junta con el océano (oeste), la kurues, serpiente que al igual que el pascola lleva una cruz en la frente, pero reside en el mar o adentro de los cerros, mantiene con el pascola una relación regulada por tabúes: los músicos de pascola no pueden ejecutar sones de serpiente durante las noches (Olavarría 1992:28). 
Sin embargo, los conjuntos de actores no están dispuestos en estancos, la comunicación entre ellos es posible y así como las cruces de piedra y madera marcan los contornos del mundo, en su parafernalia distintiva los actores portan los marcadores de su condición: el kusim rosario de madera y una flor roja de listón o estambre: la sewa. 


\section{CRUCES Y FLORES}

En este apartado planteo la necesidad de que un código espacio temporal, con una cosmología y con personajes asociados a propiedades determinadas, cuente con una expresión plástica iconográfica. Parto del hecho que la expresión gráfica multiplica las posibilidades del lenguaje mediante símbolos visuales, que al ser instantáneamente accesibles, ofrece un ensamblaje mitológico ${ }^{13}$ al evocar una narratividad articulada en torno a formas y ritmos.

Esta noción de mitograma está presente de manera tácita en el análisis de las expresiones arquitecturales, posicionales, gestuales y escénicas que he venido presentando, y junto con el código vestimentario, configura lo más idóneo de la cultura yaqui.

Cabe señalar que este acercamiento, más próximo tal vez al ethos de la cultura y a las dimensiones estilísticas, que a las cognitivas de la visión del mundo estudiada en los capitulos anteriores, tiene el ánimo de no separar tajantemente las dos dimensiones, sino hacer énfasis en una $u$ otra, con el fin de dar sentido al fenómeno analizado desde la posición que fue construido.

La dimensión estilística tiene que ver también, desde la perspectiva yaqui, con la técnica, puesto que en muchos casos se considera parte del compromiso ritual diseñar y fabricar la parafernalia ceremonial. Si bien en los últimos años ya existen artesanos profesionales, se considera ideal que el propio danzante 0 músico sea el encargado de su manufactura. Este carácter no comercial lo comparten la fabricación de petates, canastas y coronas de carrizo, así como platos y tazas de barro que se emplean exclusivamente en las fiestas, a cuyo término se destruyen.

13 Tal como lo demuestra André Leroi-Gourhan (1971), la intervención de figuras masculinas y femeninas por parejas, así como una pareja de dos animales -- frecuentemente el bisonte y el caballo, y un tercer animal, generalmente la cabra montés, el ciervo o el mamut-- para el caso del arte parietal paleolítico. 
La parafernalia ritual posee, pues, un carácter distinto al de los objetos de uso común, y con el objeto de identificar su especificidad, describiré el vestido y la parafernalia de cada conjunto de actores rituales, pero en primer término, el que se opone a todos ellos: la vestimenta cotidiana.

Por lo general, ésta se adquiere en los comercios de la zona o en los centros urbanos cercanos. Para el varón se compone de pantalón de corte vaquero y camisa a cuadros o de colores vivos con paliacates al cuello. El sombrero es imprescindible y el calzado de los individuos más conservadores es el huarache de tres puntadas fabricado con plantilla de cuero y correa trenzada, para los jóvenes o de mayor capacidad económica, botas vaqueras. La vestimenta de los niños es similar, pero acompañada de tenis o chanclas de hule. Las mujeres y niñas usan falda plisada de algodón o satín de colores vivos con encaje blanco en el borde, blusa y rebozo sobre los hombros o sobre el cabello trenzado, calzan sandalias o huaraches y como accesorio aretes, collares y pulseras de oro, chaquira o fantasía. El vestido tradicional de las mujeres, que a pesar de estar en desuso aún es confeccionado por ciertas familias, es un conjunto de falda y blusa de algodón blanco bordado con flores predominantemente rojas.

Sobre esta indumentaria se montan los signos distintivos de su vocación ritual: los iniciados se distinguen por llevar un kusim. El kusim es un rosario elaborado con cuentas de madera de torote en cuyo extremo pende la sewa, mecha de estambre de colores variados y en ocasiones una imagen de la virgen. El kusim es signo obligado de la promesa ya que es síntesis, a su vez, de los dos principios icónicos de la indumentaria ritual: cruz y flor.

Todos los iniciados portan el kusim a partir del momento que sus padrinos lo colocan alrededor de su cuello y hasta el término de su participación; cada kusim representa un año de trabajo ritual y se conserva hasta el día de la muerte en que todos juntos se ponen al cadáver en su funeral. 


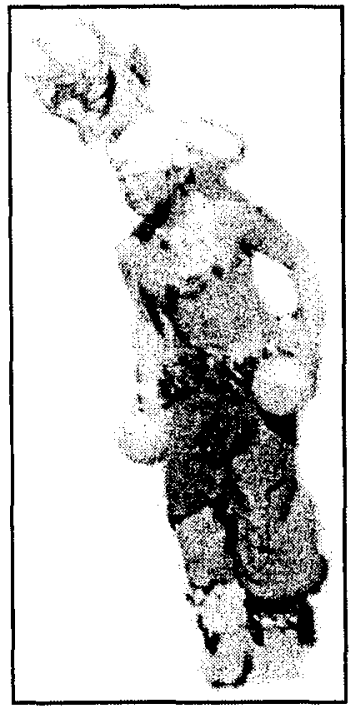

Si los neófitos deben presentarse descalzos y sin sombrero para recibir su primer rosario, los muertos, también descalzados y con la cabeza descubierta, y a menudo vestidos únicamente con calzón y camisa de algodón, son despedidos con todos los rosarios benditos que acumularon, convirtiéndose así éstos, en signo de todos los años de su vida ritual. Se comprende entonces por qué, al unir en un solo objeto la cruz y las flores, el kusim constituye el vehículo de los individuos en tránsito.

La kus y la sewa por su parte, aparecen también por separado en la vestimenta distintiva de cada uno de los actores.

Niño maso en Cárdenas, Río Yaqui, 1989

El estilo de fiesteros y del teopo yau'ra o grupo de la iglesia se caracteriza por la predominancia de las flores. Sobre su ropa de diario, las kiyostes y tenanchis portan faldillas, blusas y velos bordados con flores. La corona de los matachines recibe el nombre de sewa y la palma (insignia) y pechera de cuentas siguen el mismo principio: efecto multicolor sobre blanco.

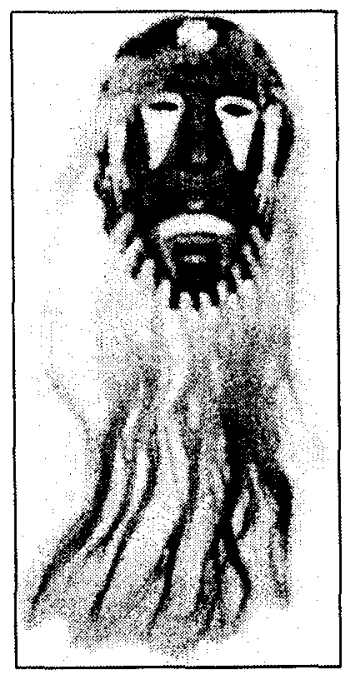

Reciben el nombre de sewam los mechones de pelo que los pascolas se anudan la madrugada de la víspera de cada fiesta, así como los listones atados a la cornamenta del masocoba. Simultáneamente, la kus está presente en la máscara de madera tallada del pascola y en los collares de concha y piedras marinas con forma de cruz del maso.

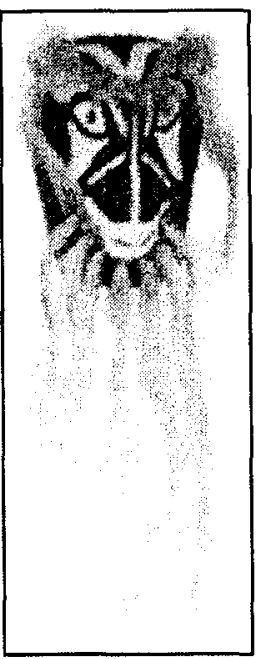


Las máscaras de pascola pueden ser de diferentes estilos: perro, lenguón y la de chivato, que es la más común, sin embargo presentan como constante iconográfica a los animalitos del monte: lagartija, ciempiés, hormigas, alacranes, dispuestos en forma de cruz blanca sobre el fondo oscuro.

La antítesis que el kohtumbre representa, se manifiesta en su triple naturaleza y expresión vestimentaria; mientras la ropa de los kabayum o caballeros de Roma no se distingue de la que los yoremes usan en sus días de trabajo, incluyendo el sombrero y sólo marcada por el kusim al cuello, los chapayekas son el Otro, su disfraz tiene que ser extravagante: apaches, cholos y negros son un ejemplo. El kusim, como el rostro, debe permanecer oculto bajo la máscara, para que al orar pasen las cuentas con la boca y aseguren así su silencio. El tercer grupo, los sontaom van todos de negro o negro sobre blanco de acuerdo al día $y$ hora que se trate.

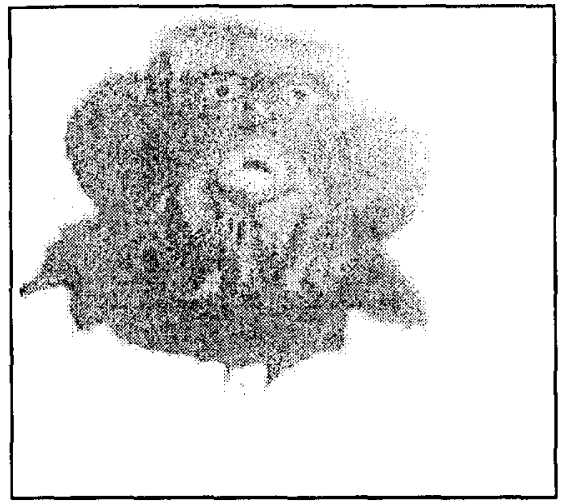

La sewa de los chapayekas es especial, su máscara-casco recibe este nombre y a menudo una flor es dibujada sobre la misma, también la llevan como ornamento de sus armas de madera. El Sábado de Gloria, cuando las sewam son lanzadas a la hoguera que forma el cuerpo de Judas ardiendo, los padrinos atan al brazo de sus ahijados un paño rojo indicativo de su nueva condición.

Si el primer grupo - pahkome, matachines y venado- se caracteriza por el predominio de sewa (sobre la cabeza) y la kus al cuello, y el pascola por el predominio de la kus, entre los fariseos coexisten tres estilos: el de los propios yoremes (kabayum con kus al cuello), los extraños (chapayekas con la kus oculta) y los que no son ni lo uno ni lo otro, o la kus misma (sontaom). 
Sólo faltaría mencionar, para completar el sistema, la ausencia completa de sewa. La kurues, serpiente acuática o de siete cabezas, cuyo nombre es homófono de arco iris (Lionnet 1977:46) se caracteriza por llevar únicamente la kus o la letra tau en la frente.

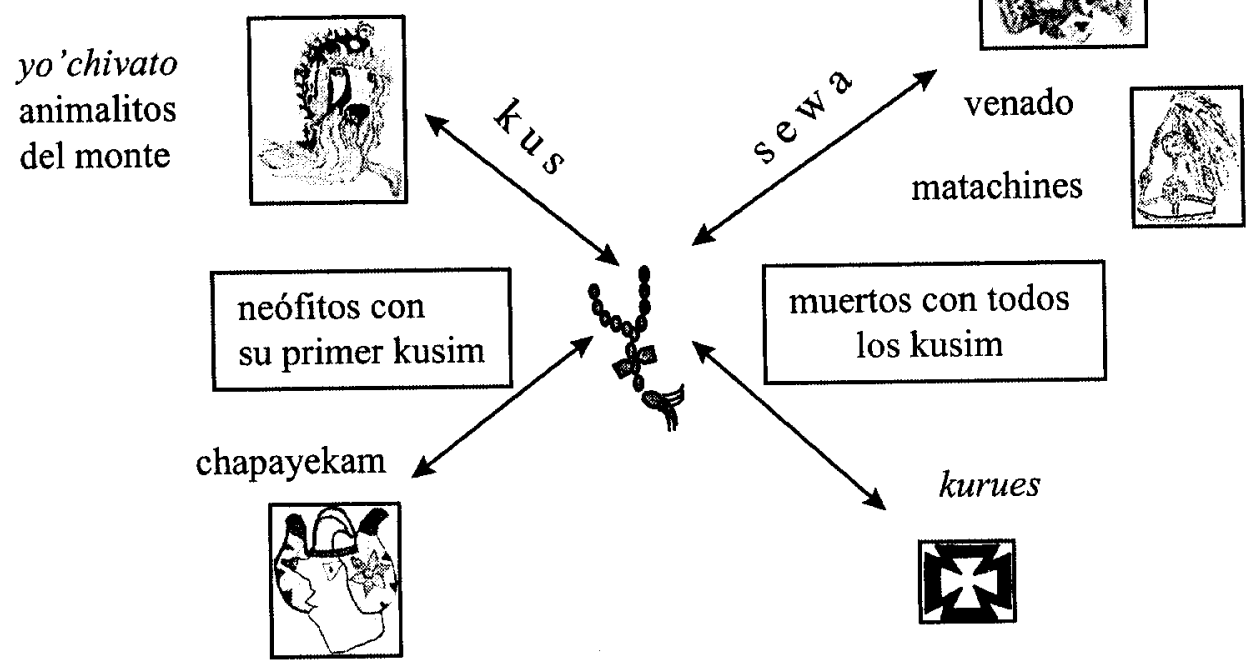


Cuyos extremos corresponden a la palma (de los matachines) frente a la tau:

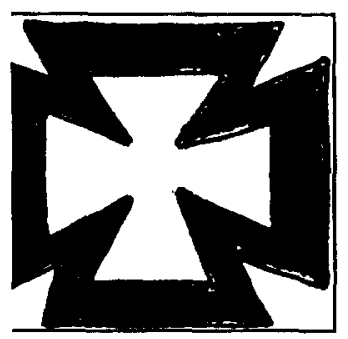

kus

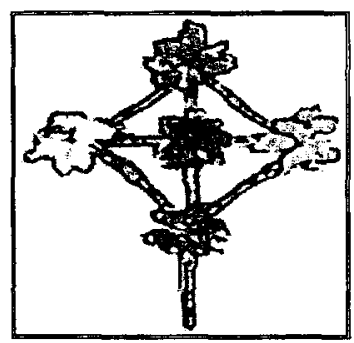

sewa

Donde sewa es una representación analógica y kus una sintética del mismo principio radial. Es decir, como polos de un mismo principio, no se oponen tal como se opondrían en un esquema simplista lo "bueno y lo malo" o "lo cristiano y lo prehispánico"; dado que no se excluyen, sino que un mismo personaje las combina, se conciben más bien como dos polos rodeados por campos de significaciones a menudo intersectados. Los mitos permiten ubicar dichas intersecciones:

"La Virgen María bajó al río por agua en un cántaro de barro rojo. Cuando llegó al arroyo, había un pequeño remolino en el lugar de donde solía tomar agua. Cuando llegó encontró un rosa roja flotando en el remolino, hasta que sumergió el cántaro y tomó la rosa. La tomó, inhaló y le gustó el perfume y deseó mostrársela a José. La puso en su regazo y regresó al sitio donde estaba José, pero no encontró la rosa. Dicen que el perfume estaba presente en ese momento. $Y$ esta es la historia yaqui de la concepción de Cristo. Todo lo relacionado con el color rojo viene de esta historia. Y muchas veces, cuando una persona cae enferma, puede ver a la Virgen llevando agua en un cántaro rojo" (Painter 1986:78). 
La referencia explícita al color rojo y a las sewam determina un amplio campo de significaciones, cuya referencia más inmediata es la asociación de las flores con la Virgen, a ella se le honra con flores de crepé de colores vivos, entre los que abunda el rojo: "al amanecer la Virgen María recoge todo lo que hicimos durante la noche. Trabajamos toda la noche y estamos con sueño y cansados, pero no nos hace falta nada, porque asi ganamos indulgencia". El color rojo y las flores están asociados también a la sangre de Cristo pues:

"Cuando la lanza atravesó el costado de Jesús en la cruz, las gotas de
sangre que cayeron se convirtieron en flores. Por esta razón las flores
son un arma especial contra el mal durante todo el año y en el período
de Cuaresma no hay flores durante siete semanas, porque no hay
matachines. Los fariseos temen a las flores, pues se cree que María creó
su ejército de matachines a la muerte de Cristo, quienes junto con los
doce apóstoles y los amigos de Jesús, pelearon contra los fariseos. Por
eso la música de los matachines se relaciona con la lucha batalla
sonim".

El mito que refiere cómo es que las flores - sangre de Cristo derrotan a los fariseos es el siguiente:

"Jesús, Pedro y Pablo iban juntos en un viaje, y mientras hablaban, un judío se acercó a ellos, a Pedro no le gustó y sacó su espada y le cortó una oreja. Jesús le dijo que no lo volviera a hacer. Y Jesús volvió a colocarle la oreja, lo sanó y le dijo que se fuera. Siguieron caminando hasta que llegaron al Monte Calvario. Estaban descansando ahí cuando el judío se acercó y le preguntó a Él si había visto al Nazareno. Dijo que Él era, pero no le creyó. Regresó otro día y dijo que era Él. La tercera vez fue capturado y se lo llevaron. Lo llevaron a la cruz de la iglesia, y fue cuando Pilatos crucificó al Señor. Cuando lo herían con la lanza, se ponían de rodillas. La sangre de Jesús caía sobre todos los judíos y por eso todos llevan una mancha de sangre en sus caras (en la máscara de los chapayekas). Los judíos volvieron a tomar el mismo camino y fueron llevados de nuevo con Jesús. Cuando lo crucificaron también intentaron huir pero tomaron un camino que los llevaba de vuelta con Jesús. Así que tuvieron que quitarse su ropa y arrepentirse de lo que hicieron. (¿Por qué los chapayekas son zurdos?) Porque cuando iban a 
crucificarlo, los Judíos venían de la izquierda, no de la derecha, sino de la izquierda. Por eso se equivocaron haciéndolo de la manera incorrecta" (Painter 1986:463)

Este relato explica además por qué la máscara de los chapayekas es sewa y la posición mediadora del color rojo. Las gotas de sangre de Jesús remiten al lenguaje de las representaciones del cuerpo y sus fluidos considerado por Turner como la fons et origo de toda clasificación: "las fuerzas y símbolos son biológica, psicológica y lógicamente anteriores a las clasificaciones sociales" (1980).

Para este autor, los símbolos primordiales están asociados a los tres colores que representan productos del cuerpo humano, cuya emisión, expulsión o producción se encuentran asociados con un incremento de las emociones. Cada una de estas experiencias corporales físicas de gran tensión emocional, clasificadas bajo el rubro de un color, son al mismo tiempo, experiencias de relaciones sociales.

En este caso, los tres colores no están aislados, forman un sistema que opone conjuntos de relaciones, el polo sewa evoca el mitograma del multicolor sobre blanco, la kus blanco sobre negro, que desde el punto de vista meramente formal, corresponde a la oposición entre un continente y un contenido. Desde el punto de vista de las relaciones sociales que condensa, el rojo ocupa la posición mediadora al unir a través de la sangre ${ }^{14}$, a la Virgen con Jesús, a los soldados de la Virgen con el kohtumbre, al tiempo ordinario y la Cuaresma.

La reconstrucción del código corporal sólo queda señalada, puesto que me interesa reincorporar el análisis de los símbolos de la parafernalia como un lenguaje más del conjunto expresivo que evoca, en última instancia, el carácter trascendente del rito, el tránsito por los mundos.

${ }^{14}$ A.B. Kempe, el lógico simbólico citado por Tumer señala: "Es característico del hombre pensar en términos de relaciones diádicas; lo habitual es que rompamos las relaciones triádicas, convirtiéndolas en un par de díadas... algunos dirían incluso que la relación triádica no es más que un par de díadas. Sería exacto, desde un punto de vista lógico, decir que todas las relaciones diádicas son triadas que constan de un miembro nulo". 


\begin{tabular}{|c|c|c|}
\hline $\begin{array}{l}\text { kus oculta } \\
\text { vestido de no yoreme }\end{array}$ & $\begin{array}{l}\text { sewa en lo alto } \\
\text { vestido de yoreme }\end{array}$ & $\begin{array}{c}\text { kus al cuello } \\
\text { vestido de flores }\end{array}$ \\
\hline \multicolumn{3}{|c|}{ descalzos y sin sombrero con la primera o todas las kusim } \\
\hline serpiente con kus en la frente & $\begin{array}{l}\text { kus en lo alto } \\
\text { animalitos d }\end{array}$ & nte sobre una máscara \\
\hline
\end{tabular}




\section{CONCLUSIÓN}

Detrás de este trabajo interpretativo subyace la necesidad de problematizar la noción de sincretismo. Esta noción, a menudo presentada como el fin, o la culminación del análisis, en mi apreciación, no es sino un dato que sirve como punto de partida para el análisis.

Al partir del supuesto que existen sistemas puros, que por determinantes externas llegaron a mezclarse, el sincretismo, entendido como la "reelaboración de las expresiones religiosas con base en la apropiación de elementos simbólicos que son readecuados a la situación de contacto cultural" (Marzal 1986). La imagen de un sistema así construido corresponde al de una cultura receptora creativa, pero hasta cierto punto "oportunista", que retoma y adecua los elementos que tienen la capacidad de amoldarse a su propio sistema'. Dicho sistema, fijado de antemano o en espera de la influencia externa, por lo general no dialoga con otros sistemas simultáneos, sino con uno solo, el catolicismo ibérico. Esta perspectiva mantiene el supuesto de que los elementos pueden separarse de las relaciones que los sustentan, de manera que, únicamente aquéllos que presentan un correlato en la religión nativa serán integrados al sistema receptor.

La visión que se obtiene de la etnografia y el análisis de los ritos y ceremonias yaquis, más que apoyar la interpretación del sincretismo como mecanismo estabilizador en la situación de contacto cultural, se orienta hacia otra dirección. Sabemos, con base en los estudios de López Austin (1989), que las religiones indígenas contemporáneas abrevan, a su vez, de un conjunto de corrientes que confluyen en una tradición más amplia como la mesoamericana.

Asimismo, que los sistemas religiosos poseen una lógica basada en signos, hay acuerdo en el hecho de que su cualidad es la de operar como el bricoleur, pero este proceso no se da de una vez por todas, ni se dio únicamente en el momento histórico del contacto, se trata de un proceso permanente: el montaje de nuevos significados sobre un significante y de nuevos significantes sobre

1 Báez-Jorge presenta un análisis de esta problemática en la antropología mexicana contemporánea (Entre los naguales y los santos. Religión popular y ejercicio clerical en el México indígena, Universidad Veracruzana, Xalapa Ver., México, 1998) 
un significado. Así, los sistemas basados en signos y perceptos, distintos a los basados en conceptos, se encuentran en un estado análogo al del efecto mismo de significación: la reverberación (Eco 1991). De manera que un sistema así concebido no puede ser descrito más que en su cualidad de proceso.

La persistencia del patrón ceremonial de Cuaresma, estudiado desde hace un siglo, no debe entenderse como un modelo estático, sino que justamente es su cualidad creativa lo que explica su permanencia.

Hoy día se acepta como un hecho que los dos misioneros jesuitas - Fray Andrés Pérez de Ribas y Fray Tomás Basilio- fueron incluso invitados por los yaquis, al observar la labor que miembros de esta orden realizaban entre sus vecinos los mayos. Este acontecimiento sui generis, situado hacia 1610, marca un hito en las relaciones entre indios y misioneros, por lo menos en el nivel regional: a los cinco días de su llegada, los dos misioneros jesuitas que llegaron por primera vez a territorio yaqui ya habían bautizado a cinco mil indígenas.

Asimismo, se asume que los yaquis, antes de la invasión hispánica, tenían su propia tradición de dramas rituales e incluso su propia transmisión de los mitos mediante la "puesta en escena" ritual (Spicer y Beals en Crumrine y Spicer en prensa). De manera que el método de enseñanza jesuita pudo haber sido, y lo fue de hecho, una convergencia con la práctica nativa, pero ello no basta para explicar por qué las enseñanzas jesuitas fueron rápidamente aceptadas, y por qué, después de la expulsión de la orden en 1767, no sólo continuaron lo que los jesuitas iniciaron, sino por qué lo hicieron aún más propio.

Estudiosas del origen de la representación dramática, afirman que la waehma yaqui difiere cualitativamente de otras alegorías como, por ejemplo, la tlaxcalteca, a la cual califican como una imitación de los dramas europeos. Estas autoras conciben los ritos yaquis como un desarrollo independiente, basado en las mismas premisas, y que alcanza un resultado sorprendente. (Spicer, Rosamond B. y Dorothy Beals en Crumrine y Spicer en prensa). 
También se ha argumentado que la conversión de los yaquis y mayos ocurrió aproximadamente un siglo más tarde que la del México central —después de 1591 - y que al ser la cultura del norte "menos compleja" y haber sido efectuada por siete $u$ ocho misioneros jesuitas para 30 mil yaquis, los misioneros se enfrentaron al problema de mostrar la cristiandad en términos inteligibles y aceptables para el pueblo y para ello tuvieron que delegar sus propias funciones en algunos de ellos, a quienes entrenaron para atender a los pobladores de las comunidades dispersas (ibidem).

Sin cuestionar este hecho, me pregunto cómo hoy día se puede explicar, que los Maehto yoremes sigan presidiendo bautizos, bodas y funerales, a pesar de que los pueblos yaquis pertenecen desde 1779 a la Arquidiócesis de Hermosillo. De manera que, más que concluir un análisis en toda su complejidad, la noción de sincretismo, reapropiación, o necesidad simbólica, abre nuevas preguntas y sugiere nuevas exploraciones.

Otro aspecto que debe considerarse, es el hecho que pocas veces se contempla la relación de las religiones de yaquis y mayos frente al universo al que sirven de entrada: el de las culturas norteñas de filiación lingüística yuma y pimana. Es interesante el intento de Bahr en esta dirección, puesto que al comparar la mitología yaqui con las mitologías no cristianas provenientes de narradores yumas y pimas identifica secuencias narrativas comunes, tales como la inundación, la muerte de un curandero o de un benefactor, la marcha de los ancestros tribales para establecer límites territoriales y el origen de la vida breve. Señala que, a pesar de sus variantes, las mitologías de los tres grupos mantienen convergencias construidas sobre la combinación de antiguos elementos compartidos (Bahr en Crumrine y Spicer en prensa).

Otros autores privilegian la influencia de las tradiciones occidentales en el drama de la Cuaresma:

"At times the Biblical story seems a little mixed up, or over-elaborated with multitudinous processions, but the Biblical story is there without a shadow of a doubt." (Beals en Crumrine y Spicer). 
O la medieval:

"The Judas procession with the figure riding backwards on an ass and the backward ritual recalls the Festum Stultorum (Feast of Fools) in which the Bishop of Fools rode backward on an ass and in which the ceremonial was as much reversed as possible" (Chambers 1903:1).

En esta tesis, partí del hecho que la religión yaqui no es un sistema contaminado, sino uno nuevo, construido como un conjunto de lógicas donde se entrelazan signos que alguna vez fueron conceptos y signos que lo siguen siendo.

Se trata de un fenómeno complejo, un proceso que ilustro con los siguientes ejemplos: se ha tomado como prueba de la eficaz labor misionera la permanencia del cargo del temastian. Fabila y Spicer señalan que este cargo deriva su nombre del castellano sacristán; no obstante, otras fuentes señalan que en lengua náhuatl existe temachti o temachtiani traducido como maestro, preceptor o predicador por Rémi Siméon (1991:466). Ello sugiere, al menos la posibilidad de tomar en cuenta que el nombre temastián no sea una derivación del castellano, sino que se trate de un préstamo del náhuatl. De ser así, en este caso el sincretismo sería una situación, históricamente justificada, interna a dos grupos indígenas.

Intentar establecer la compatibilidad o incompatibilidad, uno a uno, entre conceptos yaquis y conceptos católicos es una ruta estéril; por el contrario, la naturaleza compleja del proceso en que significantes católicos se relacionan con significados previos y a la inversa, exige una perspectiva sistémica y una referencia más amplia. Por ejemplo, la Virgen María recibe el nombre de Itom Aye (Nuestra Madre) pero se asocia con los conceptos no cristianos de la luna, la sangre y las flores; Jesucristo tiene una doble identificación, como Itomachai (Nuestro Padre y representado por el Ecce Homo) y simultáneamente, como Jesús: un curandero y héroe cultural yaqui.

Otra figura preeminente como la Virgen de Guadalupe es concebida, no como advocación de María, sino como fundamentalmente distinta. La Santísima Trinidad y la Santa Cruz merecen sitio aparte, y el contenido de esta última se aparta de la tradición occidental. Como también es el caso de San Miguel 
Suawaka, la estrella fugaz, cuya función de mensajero entre Dios y los hombres en su co-texto original, pasa en éste a cumplir la función opuesta: él lleva los cuerpos de los muertos incestuosos a la serpiente de siete cabezas que vive dentro de la montaña y provoca las tormentas, la lluvia y el viento. A su vez, esta serpiente es llamada a menudo llamado Diablo, pero el significante diablo también se asocia con Yuku, también amo de la lluvia y el viento.

En este discurso, cabe preguntarse si hiaplo equivale a diablo o a "nuestro enemigo" como también se le conoce itom bebel'eli o bebeheeri, el cual, como encarnación del mal y la envidia, es capaz de tomar casi cualquier forma animal o humana para asustar y dañar a la gente. Hay términos que se escuchan con más frecuencia en español que en yaqui, como el de infierno, aunque muchos yoremes afirman que ellos no creen en él. Prefieren $k a$ macbikuni o la oscuridad, un camino que lleva a otros mundos, pero que no es malo, está lleno de flores y arroyos...

Como se ve, las asociaciones así formuladas pueden llevar al efecto de semiosis infinita y alejarnos de la posibilidad de comprensión (Eco 1991). Por el contrario, la perspectiva estructural identifica cuáles son las asociaciones pertinentes y de qué manera, a partir del tipo de relación que establecen, resultan significativas para los actores. En este sentido, es imperativo reconocer que, los sistemas en sí mismos, no poseen límites definidos, son en última instancia borrosos, y que en términos ideales el análisis puede prolongarse al infinito.

Un aspecto de tal complejidad, en otro nivel, es el reconocimiento por parte de la población que participa de manera regular en los ciclos de los ocho pueblos, de ser fieles a la "religión yaqui", mientras otros sectores se pronuncian como católicos, sin que ello se vea reflejado en sus creencias y prácticas. No obstante, la propia ideología del sistema cultural impone sus fronteras: a pesar de estar sometidos a la presión de otros sistemas religiosos como el protestantismo y testigos de Jehová, ya sea la que ejercen directamente los misioneros o la población mestiza avecindada, los yoremes no han aceptado su influencia. Actualmente, sus representantes no sólo demandan respeto, también: 
"Que exista una modificación de la Ley de Asociaciones Religiosas y Culto Público, ya que ésta, en su Artículo 9, fracción III, determina y da la libre expresión de propagar la doctrina de las asociaciones religiosas. Por tal motivo, los pueblos yaquis demandan que las asociaciones religiosas distintas a las nuestras respeten nuestros usos y costumbres, absteniéndose a propagar sus doctrinas dentro de territorios indígenas, ya que, lejos de beneficiar, provocan confusión y desorientación a las familias de los ocho pueblos yaquis." (Rosalino Choqui Moroyoqui 1998:139)

El curso que puede tomar el proceso de construcción de metalenguajes es impredecible, un signo puede conservar la forma pero enfatizar una función distinta, como puede ser el ejemplo de la plegaria musical yaqui. Nadie conoce el significado literal de las oraciones de las cantoras: las niñas que se inician en este cargo identifican ante todo el ritmo y la melodía de las oraciones, pero no su contenido verbal. En este sentido, la cadena de signos se vuelve mero significante, se aleja de la función comunicativa para privilegiar, en el nuevo contexto, la función fática ${ }^{2}$ (Jakobson 1980).

En un momento de mi investigación recibí la crítica de centrar mi atención en lo que aparecía como el polo occidental de la religión yaqui: la sucesión de ritos en fechas coincidentes del santoral, la representación dramática de pasajes bíblicos o la referencia constante a Jesús, María y los santos; no obstante, mientras más profundizaba en el conjunto tal como se presentaba, sin diseccionarlo en la "religión del monte" y la de "los pueblos", con mayor fuerza salía a relucir un sistema esencialmente distinto. Este sistema original corresponde a un modelo de cosmología que no se sitúa a medio camino entre sus fuentes naturales, sino que se separa de ambas.

Este fenómeno es natural a la cultura y constituye lo que Lotman concibe como criollización: las partes del código del emisor y del receptor que no se entrecruzan, constituyen la zona que se deforma, se somete al mestizaje o se reestructura de cualquier otro modo. Este proceso puede limitarse a la invención de léxicos sin gramática propia, tratándose de una estructura

${ }^{2}$ El concepto de función fática, acuñado por Malinowski y desarrollado por Jakobson principalmente, da cuenta de la propiedad de cierto tipo de texto en el que es más importante el 'decir' que 'lo que se dice', los conjuros mágicos caen dentro de esta categoría. 
hipocodificada, un sistema pidgin; o bien, cuando se afectan las estructuras sintácticas, estamos frente a una estructura hipercodificada, un caso de criollización.

En síntesis, frente al modelo comunicativo estático propio de la noción de sincretismo, sugiero un modelo que reconoce como cualidad inherente a los sistemas de signos, la existencia de regiones en transición, en movimiento, de zonas entre los códigos del emisor y el receptor que no se entrelazan:

"El estudio de la cultura como fenómeno significativo hace suponer que lo normal precisamente es que los que intercambian información no usen un código común, sino dos diferentes que hasta cierto punto se interceptan. Así el acto comunicativo no es una transmisión pasiva de información sino una traducción, una re-codificación del mensaje. El receptor debe reconstruir el mensaje transmitido, por lo que la incomprensión, la comprensión incompleta, etc., no son productos laterales del intercambio de información debidos al ruido, a algo no inherente a la comunicación, sino que corresponden a su esencia real." (Lozano en Lotman y la Escuela de Tartu, 1979:29)

Con base en esta cualidad inherente a la cultura se comprende que el código dominante del sistema religioso yaqui, su estructura mitológica y ritual, haya sido objeto de una criollización, es decir, de una nueva ordenación en el nivel sintáctico. Asimismo permite reconocer que no todos los códigos son afectados de la misma manera, quedando la posibilidad de la coexistencia, al interior de un sistema cultural, de aspectos hipo e hipercodificados.

Al poner énfasis en el cómo y no en el qué, considero que el modelo construido sobre los conceptos de hipo e hipercodificación, el texto sagrado y la gramática, el código elaborado y el restricto, permite determinar el momentum del proceso comunicativo. (Bernstein 1991; Lotman 1979; Eco 1991 y Douglas 1978)

Este modelo marca el punto de retorno a una conceptualización del ciclo ritual como un código restricto, donde los puntos de mayor interés son, precisamente, los intersticios del código, las anomalías sintácticas, los incestos lógicos; esto es, la intersección de los cultos estacionales, el acercamiento 
extremo de sol y luna, la muerte en época de vida y el parentesco ritual frente a la alianza.

De manera que, al transportar la problemática al terreno de la comunicación entre sistemas, retorno a la pregunta que formulé al inicio ¿cómo se relacionan los discursos tradicionales y los no tradicionales? ¿cómo entender un sistema que junta cruces y flores? 


\section{BIBLIOGRAFIA}

Acevedo, María Luisa et. al. (editores), Rituales y religiosidad, Departamento de Etnología y Antropología Social, INAH, México, Cuaderno de Trabajo núm. 39, 1990

Aguilar Camin, Héctor, La frontera nómada: Sonora y la Revolución Mexicana, Siglo XXI editores, México, 1981

Aguilar Zéleny, Alejandro Sergio, Los ritos de la identidad: Estrategias de persistencia y diversidad étnica en el Noroeste de México, Tesis de Maestria en Antropología Social, ENAH, México, 1998

Aguilar Zéleny, Gerardo David, Análisis léxico y morfológico de tres narraciones yaquis, Tesis de Licenciatura en Lingüística, ENAH, México, 1996

Aguirre Beltrán, Gonzalo, Cuijla. Esbozo etnográfico de un pueblo negro, Lecturas Mexicanas 90, SEP, México, 1985

Alegre, Francisco Xavier, Historia de la Compañia de Jesús en Nueva España (1841-1842), México, Imprenta J.M. Lara

Alleau, René, La Science des Symboles. Contribution a l'étude des principes et des méthodes de la symbolique générale, PUF, Paris, 1989

Arricivita, fray Juan Domingo, Crónica seráfica y apostólica del Colegio de Propaganda Fide de la Santa Cruz de Querétaro en la Nueva España (1792)

Aveni, Anthony, Skywatchers of Ancient Mexico, University of Texas Press, Austin, 1980

Aveni, Anthony editor, Native American Astronomy, University Of Texas Press, Austin, 1977 Astronomía en la América Antigua, México, Siglo XXI editores, 1980

Aveni, Anthony F. y Gordon Brotherson, editores, Calendars in Mesoamerica and Peru: Native American Computations of Time, BAR International Series 174, Oxford

Aveni, Anthony F. y H. Hartung, "The cross petroglyphs: ancient Mesoamerican astronomical and callendarical symbol", Indiana, 6, 1980, págs. 37-54

Baéz-Jorge, Félix, Entre los naguales y los santos. Religión popular y ejercicio clerical en el México Indígena, Biblioteca Universidad Veracruzana, Xalapa Veracruz, México, 1998

Bahti, John, Southwestern Indian Ceremonials, KC Publications Inc., Las Vegas, Nevada, 1987 
Baity, Elizabeth, "Archaeoastronomy and Ethnoastronomy so far", Current Anthropology, 14 págs. 388-499

Balandier, Georges, El desorden. La teoría del caos y las ciencias sociales. Elogio de la fecundidad del movimiento, Gedisa, Barcelona, 1997

Barker, G.C., "The yaqui easter ceremony at Hermosillo", Westem Folklore, núm. 16, 1957

Barrera Herrera, Eduardo "Más subvierte el Diablo por viejo: transgresión simbólica entre los yaquis de Arizona", Frontera Norte, Publicación semestral de El Colegio de la Frontera Norte, vol. 8, núm. 15, enero-junio de 1996, págs. 133-146

Barthes, Roland, Elementos de semiologia, Traducción Alberto Méndez, Madrid, A. Corazón, 1971

El grado cero de la escritura, seguido de nuevos ensayas criticos, Traducción de Nicolás Rosa Héctor Schmucler, México, Siglo XXI editores, 1973

Mitologías, Traducción de Héctor Schmucler, México, Siglo XXI editores, 1997

Basauri, Carlos y Alfonso Fabila, "Sistema de gobierno y administración de justicia yaqui" en Teresa Valdivia Dounce (coordinadora), Usos y costumbres de la población indígena en México. Fuentes para el estudio de la normatividad, NI, México, 1994, págs. 203-222

Bateson, Gregory, Espiritu y Naturaleza, Buenos Aires, Amorrortu, 1990

Baudrillard, Jean, Crítica de la economía política del signo, Traduccion de Aurelio Garzón, México, Siglo XXI editores, 1977

Beals, Ralph, "The Comparative Ethnology of Northern Mexico before 1750", Iberoamericana, núm. 2, University of California Press, Berkeley, 1932

"The Contemporary Culture of the Cahita Indians", Bureau of American Ethnology, Bulletin no. 142, Smithsonian Institution, Washington D.C., 1945

Beals, Ralph y E.C. Parsons, "The Sacred Clowns of the Pueblo and Mayo-Yaqui Indians", American Anthropologist, vol.36, Menasha, Wisconsin, 1934

Beattie, John H.M., "On Understanding Ritual" en B.R. Wilson ed., Rationality, Oxford, 1970

Bouchard, Gérard, "La región culturelle: un concept, trois objects. Essais de mise au point" en Fernand Harvey ed. La región culturelle, Quebec, Institut Québecois de Recherche sur la Culture, 1994 
Bourdieu, Pierre, Language and Symbolic Power, Edited and introduced by John B. Thompson, Harvard University Press, Cambridge, Massachusets, 1984

Broda, Johanna, "Arqueoastronomía y desarrollo de las ciencias en el México prehispánico" en Marco Arturo Moreno Corral (editor), Historia de la astronomía en México, México, SEPFCE, La Ciencia desde México, vol. 4

Broda, Johanna, et. al., Arqueoastronomia y etnoastronomia en Mesoamérica, Serie de Historia de la Ciencia y la Tecnología, Instituto de Investigaciones Históricas, UNAM, México, 1991

Buelna, Eustaquio, Arte de la lengua cahita, edición facsimilar, Siglo XXI editores / Difocur, Sinaloa, México, 1989

Burton, Susan S., Malichi, the flower fawn: the symbolism of the Yaqui Deer Dance, MA Thesis, Texas Women's University, 1990

Butler, Peggy, "Deer Dance", Mexican Life, núm. 28, México, julio, 1952

Calendario de fiestas tradicionales, Coordinación de las Culturas Populares, Subsecretaría de Cultura y Difusión Popular, SEP, México, 1977

Camou, Ernesto, "Las etnias originarias", Historia general de Sonora, Gobierno del Estado de Sonora, Hermosillo, 1985

Cantoni, Remo, El pensamiento de los primitivos, Buenos Aires, Amorrortu, 1989

Cárdenas del Río, Lázaro, Propuesta del presidente de la República, Lázaro Cárdenas, a las jefaturas de las colonias yaquis con el objeto de hacer justicia a los sectores indígenas y buscar el mejoramiento integral de la Tribu Yaqui. Vicam, Sonora, 1939, Archivo General de la Nación, Lázaro Cárdenas del Río, vol. 685, exp. 533.11-1

Carre, Shirley Deshon, "The Chapayeka Complex: Change and Persistence of Forms" en Crumrine, Nye Ross y R. B. Spicer eds., Lent and Holy Week in Northwest Mexico and Southwest United States, Lanhaus, Maryland, University Press of America, en prensa

Castaneda, Carlos, Las enseñanzas de Don Juan: una forma yaqui de conocimiento, México, Fondo de Cultura Económica, 1971

Una realidad aparte: nuevas conversaciones con Don Juan, México, Fondo de Cultura Económica, 1974

Viaje a Ixtlán: las lecciones de Don Juan, México, Fondo de Cultura Económica, 1975

Relatos de poder, México, Fondo de Cultura Económica, 1976

Carta de Carlos Castaneda dirigida a R. Gordon Wasson, fechada el 6 de septiembre de 1968, publicada en Magical Blend, octubre 1993 
Cazeneuve, Jean, Sociología de Marcel Mauss, Barcelona, Ediciones Península, 1970

Choqui Moroyoqui, Rosalino, "Asentamiento de religiones que afectan creencias, usos y costumbres" en Yuri Escalante et.al., Derechos religiosos y pueblos indigenas, Instituto Nacional Indigenista, México, 1998, págs. 139-140

Clavijero, Francisco Javier, Historia antigua de México, 4 tomos, México, Porrúa, 1964

Closs, Michael P., "Cognitive aspects of ancient maya eclipse theory" en Anthony Aveni ed., World Archaeoastronomy, Selected Papers from the Second Oxford International Conference on Archaeoastronomy, Cambridge University Press, 1989

Cole, Michael y Sylvia Scribner, Cultura y pensamiento. Relación de los procesos congnoscitivos con la cultura, México, Limusa, 1977

Crumrine, Nye Ross, "The dramatization of oppositions among the Mayo Indians of Northwest Mexico" en George Pierre Castil and Gilbert Kushner (editores), Persistent peoples. Cultural enclaves in perspective, Tucson, Arizona, The University of Arizona Press, 1981

Crumrine, Nye Ross y R. B. Spicer editors, Lent and Holy Week in Northwest Mexico and Southwest United States, Lanhaus, Maryland, University Press of America, en prensa

Dabdoub, Claudio, Historia del Valle del Yaqui, Porrúa, México,1965

Decorme, Gerardo S.J., Historia de la Compañia de Jesús en la República Mexicana durante el siglo XIX 1880-1914, Chihuahua, 1955

Deeds, Susan, Legacies of Resistance, Adaptation and Tenacity. History of the Native Peoples of Northwest Mexico, ponencia presentada en el Simposio de Historiadores Mexicanos, Canadienses y de los Estados Unidos, octubre 1994

Delacampagne, Christian y Bernard Traimond, "La polémique Sartre / Lévi-Strauss revue", Les Temps Modernes, núm. 596, noviembre - diciembre 1997

de la Vorágine, Santiago, La leyenda dorada, tomo 1, Alianza Editorial, Madrid, 1989

de Guzmán, Nuño, Memorias de los servicios que había hecho Nuño de Guzmán desde que habia sido nombrado gobernador de Pánuco en 1529, José Porrúa e hijos, México, 1955

Desvaux, Emmanuel, "L'Alliance et la filiation comme maîtrise de l'espace, le territoire comme gouvernement des hommes", François Héritier-Augé et E. Copet-Rougier eds., Les Stratégies de l'alliance matrimoniales: Economie, politique et fondements symboliques, 
Paris, Editions des Archives Contemporaines, Collection Ordres Sociaux, 1994, págs. 4772

Díaz Pérez, María. Cristina, Las relaciones de parentesco en tres comunidades afromestizas de la Costa Chica de Guerrero, Tesis de licenciatura en Etnología, ENAH, México, 1995

Diccionario Maya Cordemex, Mérida, Yucatán, 1975

Diccionario de la lengua maya, por D. Juan Pío Pérez concluido en 1877, prólogo de Eligio Ancona

Douglas, Mary, Simbolos naturales. Exploraciones en cosmología, Versión española de Carmen Criado, Alianza Editorial, Madrid, 1978

Durand, Gilbert, Las estructuras antropológicas de lo imaginario, Taurus, Madrid, 1989

Durkhéim, E. y M. Mauss, "De ciertas formas primitivas de clasificación. Contribución al estudio de las representaciones colectivas (1903), Separata del Année sociologique, 6, págs. 13-41

Eco, Umberto, Tratado de semiótica general, Lumen, México, 1991

Ellul, Jacques, The Political Illusion, Nueva York, Alfred A. Knopf, 1968

Evans-Pritchard,E.E., Brujería, magia y oráculos entre los azande, Anagrama, Barcelona, 1976

Las teorias de la religión primitiva, Siglo XXI editores, Madrid, 1976

Evers, Larry y Felipe S. Molina, Yaqui Deer Songs. Maso Bwikam, A Native American Poetry, Sun Tracks and The University of Arizona Press, Tucson, 1987

Fabila, Alfonso, Los indios yaquis de Sonora, Biblioteca Enciclopédica Popular, SEP, México, 1945

Las tribus yaquis de Sonora, su cultura y anhelada autodeterminación, México, INI, Serie Clásicos de la Antropología Mexicana, 1978

Fergusson, Ema, Dancing gods. Indian ceremonials of New Mexico and Arizona, Albuquerque, University of New Mexico Press, New Mexico, 1988

Fernandez, James, editor, Beyond Metaphor, Stanford University Press, Stanford California, 1990

Ferrer, León, "El contexto calendárico del ciclo de Pascua" en Alteridades, aZo 7, ndm. 13, 1997, págs. 85-88 
Figueroa Valenzuela, Alejandro, Los que hablan fuerte, desarrollo de la sociedad yaqui, Noroeste de México, Centro Regional del Noroeste, INAH/SEP, Hermosillo, 1985

Por la tierra y por los santos. Identidad y persistencia cultural entre yaquis y mayos, Conaculta, México, 1994

Foucault, Michel, La arqueología del saber, Siglo XXI editores, México, 1983

Frazer, Sir James, La rama dorada, Fondo de cultura económica, México, 1964

Galarza, Joaquín, Estudios de escritura indigena tradicional azteca-náhuatl, CEMCAArchivo General de la Nación, México, 1979

Galinier, Jacques, La mitad del mundo. Cuerpo y cosmos en los rituales otomies, México, UNAM-CEMCA-INI, 1990

Geertz, Clifford, La interpretación de las culturas, México, Gedisa, 1987

Conocimiento local. Ensayos sobre la interpretación de las culturas, Paidós básica, Buenos Aires, 1994

Giddings, Ruth W., "Yaqui of Mexico and their Folk Literature", The Kiva, vol. 8, págs. 18-22, 1942-43

"Yaqui Myths and Legends", Anthropological Papers of the University of Arizona, núm.. 2, University of Arizona, Tucson, 1959

Gimate-Welsh H., Adrián S., Espacio-Identidad. El territorio, la autonomía y los derechos de los pueblos indigenas de México, manuscrito s.f.

Gìménez Montiel, Gilberto, "Territorio y cultura" en Culturas contemporáneas, Epoca II, vol. II, núm.. 4, diciembre 1997, págs. 9-30

La teoría y el análisis de la cultura, Programa Nacional de Formación de Profesores Universitarios en Ciencias Sociales, SEP-UG-COMECSO, Guadalajara, México, 1987

Goody, Jack, La domesticación del pensamiento salvaje, Madrid, Akal Universitaria, 1985

Goody, Jack, comp., Cultura escrita en sociedades tradicionales, Gedisa Editorial, Barcelona, 1996

Gouy-Gilbert, Cécile, Une resistence indienne. Les Yaquis du Sonora, Féderop, Lyon, 1983

Graulich, Michel, Mythes et rituels du Mexique ancien préhispanique, Palais des Academies, Bruxelles, 1987 
Greimas, J. y E. Rastier, The Interaction of Semiotic Constraints, Game, Play, Literature, Yale French Studies, no. 41, 1968

Griffith, James S. y Felipe Molina, Old men of fiesta. An Introduction to the Pascola Arts, The Heard Museum, Phoenix, Arizona, 1980

Grupo de Entrevernes, Análisis semiótico de los textos. Introducción-teoría-práctica, Ediciones Cristiandad, Madrid, 1982

Halliwell, Leslie, The filmgoer's companion, Equinox Books, New York, 1971

Héritier-Augé, Françoise, "El muslo de Júpiter. Reflexiones sobre los nuevos métodos de procreación", El hombre, Selección de artículos de la Revista Francesa de antropología, Editorial Manantial, BuenosAires, págs. 39-50

Herrera Quiñones, Jesús Emigdio, Filosofia Odami, Programa Cultural de las Fronteras, 1981

Holden et.al., "Studies of the yaqui indians of Sonora Mexico", Texas Technological College Bulletin , núm. 1, vol. 12, 1936

Hill, Jane H., "The Flower World of Old Uto-Aztecan", Journal of Anthropological Research, Department of Anthropology, University of Arizona, Tucson, no. 48, summer 1992, págs. 117-144

Hu-Dehart, Evelyn, Missionaries, Miners \& Indians: Spanish Contact with the Yaqui Nation of Northwestern New Spain, 1533-1820, Tucson, University of Arizona Press, 1981 Yaqui resistence and survival. The struggle for Land and Autonomy, 1821-1910, Madison, 1984

Instituto Nacional Indigenista, Grupos Étnicos de México, vol. I, 1982

Jakobson, Roman, El marco del lenguaje, Fondo de Cultura Económica, México, 1980

Jáuregui, Jesús e Ives-Marie Gourio editores, Palabras devueltas. Homenaje a Claude Lévi-Strauss, INAH-IFAL-CEMCA, México, 1986

Johnson, Jean Basset, "Sonora Dance Regalia", El México Antiguo, tomo V, 1940-41

El idioma yaqui, Instituto Nacional de Antropología e Historia, México, 1962

Kelley, Jane Holden, Mujeres yaquis. Cuatro biografias contemporáneas, FCE, México, 1982

Kelly, Isabel, "Folk Practices in North Mexico", Latin American Monographs, no. 2, Institute of Latin American Studies, University of Texas Press, Austin, 1965 
Kepes, Gyorgy comp., La estructura en el arte y en la ciencia, Organización Editorial Novaro, México, 1970

Kessell, John L. Friars, Soldiers and Reformers. Hispanic Arizona and the Sonora Mission Frontier, 1767-1856, Tucson, University of Arizona Press, 1976

Kirchhoff, Paul, "Mesoamérica. Sus límites geográficos, composición étnica y caracteres culturales", suplemento de la revista Tlatoani, México, ENAH, 1967

Kolaz, T.M., "Yaqui Pascola Masks from the Tucson Area", American Indian Art, 11 (1), 1985 , págs. $38-45$

Kurath, Gertrude, "The kinetic ecology of Yaqui dance instrumentation", Ethnomusicology, no. 10 (1), Connecticut, january 1966

Kumth y E.H. Spicer: "A brief introduction to yaqui, a native language of Sonora", University of Arizona Social Sciences Bulletin , núm. 10, 1947

Lakoff, George, "Hedges: A Study in Meaning Criteria and the Logic of Fuzzy Concepts", en Donald Hockney et. al., Contemporary Research in Philosophical Logic and Linguistic Semantics, Dordrecht, Reidel, 1975

Lakoff, George y Mark Johnson, Metáforas de la vida cotidiana, Ediciones Cátedra, Madrid, 1986

Latour, Bruno, Science in action; how to follow scientists and engineers through society, Cambridge, Mass., Harvard Universtiy, 1987

Nous n'avons jamais été modernes, Paris, La Découverte, 1991

Latour, Bruno and Jocelyn de Noblet eds. "Les vues de l'esprit: visualisation et conaissance scientifique", Culture Technique, numero 14

Leach, Edmund R., Cultura y comunicacion. La lógica de la conexión de los símbolos, Siglo XXI editores, Madrid, 1976

"Genesis as Myth" en John Middleton ed., Myth and Cosmos, Tavistock, London, 1980

"High School", en Jáuregui, Olavarría y Franco coords., Cultura y comunicación. Edmund Leach in memoriam, UAM-CIESAS, México, 1995

Lenclud, Gérard, “Qu'est-ce que la tradition?" en Marcel Detienne, Transcrire les mythologies, Albin-Michel, Paris, págs. 25-45

Leroi-gourhan, André, El gesto y la palabra, Traducción de Felipe Carrera, Ediciones de la Biblioteca, Universidad Central de Venezuela, 1971

Las religiones de la prehistoria, Editorial Lerna, Barcelona, 1987 
Lévi-strauss, Claude, Lo crudo y lo cocido. Mitológicas I, Fondo de Cultura Económica, México, 1968

El origen de las maneras de mesa. Mitológicas III, Siglo XXI editores, México, 1981

"Une préfiguration anatomique de la gemelité", Le regard eloigné, Plon, Paris, 1983

El pensamiento salvaje, México, Fondo de Cultura Económica, 1984

Des symboles et leurs doubles, Plon, Paris, 1989

Historia de Lince, Anagrama, Barcelona, 1992

Regarder Ecouter Lire, Plon, Paris, 1993

"Retours en Arrière", Les Temps Modernes, núm 598, mars - april, 1998

Lévi-strauss, Claude et Didier Eribon, Des près et de loin, Plon, Paris, 1990

Lévy-Bruhl, Lucien, La mitología primitiva, Barcelona, Península, 1978

Lionnet, Andrés, Los elementos de la lengua cahita, UNAM, México, 1977

López Austin, Alfredo, Los mitos del tlacuache, Alianza Editorial Mexicana, México, 1989

Cuerpo humano e ideología. Las concepciones de los antiguos nahuas, UNAM, México, 1989

Lotman, Jurij M. y escuela de Tartu, Semiótica de la cultura, Introducción, selección y notas de Jorge Lozano, Ediciones Cátedra, Madrid, 1979

Lumholtz, Carl, El México Desconocido, Instituto Nacional Indigenista, México, 1981

MacIntyre, Alasdair, Whose Justice? Which Rationality?, University of Notre Dame Press, 1988

Magaña, Edmundo, Orión y la mujer Pléyades. Simbolismo astronómico de los indios kaliña de Surinam, CLAS, no. 44, 1988

Mange, Juan Mateo, Diario de las exploraciones en Sonora. Luz de tierra incógnita, México, Talleres Gráficos de la Nación, 1985

Manrique Castañeda, Leonardo, El eclipse en el mundo prehispánico, INAHCONACULTA, México, 1991

Malinowski, Bronislaw K, Coral Gardens and Their Magic. The Language of Magic and Gardening, 2 vols., London, George Allen \& Unwin, 1935

Magia, ciencia, religión, Ariel, Barcelona, 1977

Maranda, P. y E. Kongas, Structural Models in Folklore and Transformational Essays, La Haya, Mouton, 1971

Structural Analysis of Oral Tradition, Philadelphia, 1971 
Marzal, Manuel, "Análisis etnológico del sincretismo iberoamericano", Cristianismo y sociedad, núm. 88,1986

McGuire, Thomas R., Politics and Ethnicity on the Rio Yaqui: Potam Revisited, University of Arizona Press, Tucson, 1986

Mendoza, Vicente T., "Folklore y música tradicional de la Baja California y Sonöra", Anuario de la Sociedad Folklórica de México, núm. 10, México, 1955

Millán, Saúl, Miguel Angel Rubio y Andrés Ortíz, Historia y etnografia de la fiesta en México, Colección Fiestas de los Pueblos Indígenas, INI, México, 1994

Moctezuma, José Luis, "Las lenguas indígenas del Noroeste de México. Pasado y presente" en Gutiérrez y Gutiérrez coords., El Noroeste de México. Sus culturas étnicas, Museo Nacional de Antropología, México, 1991

Molina, Fray Alonso de, Vocabulario en lengua castellana y mexicana, México, Pornia, 1977

Morgan, Lewis Henry, La sociedad primitiva, Prólogo de Carmelo Lisón Tolosana, Editorial Ayuso Pluma, Madrid,1980

Morick, H. ed., Wittgenstein and the Problem of Other Minds, Humanities Press, Nueva Jersey, 1981

Munguía Murillo, Mario, "Cuaresma yaqui en Hermosillo", Memoria del V Simposio de Historia de Sonora, Universidad de Sonora, Hermosillo, 1979

Nentvig,Juan, El rudo ensayo, INAH, Colección Científica, México, 1977

Needham, Rodney, Right and Left: Essays in Dual Symbolic Classification, University of Chicago Press, Chicago, 1973

Nolasco Armas, Margarita, Estratificación intra e interétnica, INAH, mecanoescrito, México, 1974

Ochoa Zazueta, Jesús Angel, Los kiliwa y el mundo se hizo asi, INI, México, 1978

O'Keefe, Daniel Lawrence, Stolen Lightning: The Social Theory of Magic, The Continuum Publishing Company, New York, 1982

Olavarría, María Eugenia, "La mitología cosmogónica del Occidente de México" y "La mitología cosmogónica del Noroeste" en Jesús Monjarás-Ruiz coordinador, Mitos cosmogónicos del México indigena, INAH, Colección Biblioteca, México, 1987, págs. 209305 
Análisis estructural de la mitología yaqui, Instituto Nacional de antropologia e Historia Universidad Autónoma Metropolitana, Colección científica, México, 1989

Símbolos del desierto, Universidad Autónoma Metropolitana, Colección Texto y Contexto núm.10, México, 1992

"Yaqui", Encyclopedia of World Cultures, vol. VIII Middle America and the Caribbean, G.K. Hall \& Co., Boston, Massachusetts, 1995, págs. 305-308.

"Los yaquis", Etnografia Contemporánea de México, Volumen I Región Noroeste, Instituto Nacional Indigenista, México, 1995 págs. 531-573

Yaquis, Colección Pueblos indígenas de México, Instituto Nacional Indigenista, México, 1995

"Mito, magia, religión" en Ricardo Avila Palafox comp., Jornadas de antropologia, Universidad de Guadalajara, México, 1989, págs. 143-157

"Ruidos en el bosque", Galeras, Fondo de Cultura Económica, México, 1991

"La noche diurna. mitología de los eclipses" en Jesús Jáuregui, María Eugenia Olavarría y Víctor Franco coords., Cultura y comunicación. Edmund Leach in memoriam, UAMCIESAS, 1996, págs. 273-287

"Origen y destino en el discurso mítico", Discursos y mitos. Algunas aproximaciones, Departamento de filosofia, UAM, 1996

"El pensamiento salvaje y la importancia de ser imperfecto", Alteridades. Símbolos, experiencias, rituales, UAM, año 7, núm. 13, 1997, págs. 33-38.

Olmos Aguilera, Miguel, El sabio de la fiesta. Música y mitología en la región cahítatarahumara, Colección Biblioteca del INAH, México, 1998

Ortner, Sherry B., La teoría antropológica desde los años sesenta, traducción de Rubén Páez, Editorial Universidad de Guadalajara, Cuadernos de Antropología, 1993

Overing, Johanna ed., Reason \& Morality, Tavistock, London, 1985

Painter, Muriel Th., The Yaqui Easter Ceremony at Pascua, Chamber of Commerce, Tucson 1950

With Good Heart: Yaqui Beliefs and Ceremonies in Pascua Village, University of Arizona Press, Tucson, 1986

Painter, Muriel Th., R. Zavala e I. Álvarez: "A yaqui Easter sermon" en University of Arizona Social Sciences Bulletin, núm. 26, 1955

Palou, fray Francisco, "Historia de la vida y apostólicas tareas del venerable padre fray Junípero Serra y de las misiones que fundó en la California Septentrional (1787)", en Manuel Orozco y Berra, Documentos para la Historia de México, 7 vols. $4^{\text {a }}$ serie, 1857

Parsons, Elsie C., Pueblo Indian Religion, vol. II, University of Chicago Ethnological Series, University of Chicago Press, 1939 
Pfefferkorn, Ignaz, Sonora. A description of the Province (1794-1795), traducción de Th. E. Treutlein, Albuquerque, 1949

Pérez de Ribas, Andrés, My Life Among the Savage Nations of New Spain, Tomas Antonio Robertson, trad., Los Angeles:Ward Ritchie, 1968

Historia de los triunfos de nuestra santa fé entre gentes las mas bárbaras y fieras del nuevo orbe, 3 vols., Ed. Layac, México, 1944

Perrot, et. al., La mythologie programmé. L'economie des croyances dans la societé moderne, Presses Universitaires de France, Paris, 1992

Pierce, J.R., “Símbolos, señales y ruidos", Revista de Occidente, Madrid, 1962

Pitt-Rivers, Julian, "Seudoparentesco" en David Sills editor, Enciclopedia Internacional de Ciencias Sociales, Madrid, Aguilar, vol. VII, 1975, págs. 596-601

Poitier, P., J.P. Bouchaud, J.-P Delahaye, L. De Bonis y M. Gross "La importancia de ser imperfecto", Investigación y ciencia. Edición española de Scientific American, octubre 1994, págs. 67-79

Propp, Vladimir, Edipo a la luz del folklore, Bruguera, Barcelona, 1983

Publicaciones Herrerías S.A., Alma Grande. El yaqui justiciero, núm. 199, "El duelo", México, 20 de marzo de 1965

Pyke, Kenneth K., Talk, Thought and Thing, Summer Institute of Linguistics, 1993

Racine, L., "La formule canonique du mythe: analogie et classifications sociales", L'Homme, 135, juillet-septembre, 1995

Radding, Cynthia, Las estructuras socioeconómicas de las misiones de la Pimeria Alta, 1768-1850, México, INAH, 1979

"Población, tierra y la persistencia de comunidad en la Provincia de Sonora, 1750-1800", Historia Mexicana, XLI:4, 1992

Reynoso, Carlos, Teoria, Historia y Crítica de la Antropologia Cognitiva. Una propuesta sistemática, Ediciones Búsqueda, Buenos Aires, 1986

Ricoeur, Paul, El discurso de la acción, Traducción Pilar Calvo, Madrid, Cátedra, 1988

Rodríguez, Blanca, "De pan y grageas: el rito yaqui", México indígena, segunda Epoca, núm. 7, INI, México, noviembre - diciembre 1985

Rommey, A.D. y D'Andrade, "Transcultural Studies in Cognition", American Anthropologist Special Publication, vol. 66, 1964 
Rossi, Ino, et.al., The Logic of Culture. Advances in Structural Theory and Methods, Bergin Pub. Inc., 1982

Rouget, G., "Ethnomusicologie d'un rituel. La représentation, ou de Velázquez a Francis Bacon", L'Homme, 133, janvier-mars 1995

Ruiz, Antonio, Relación de Antonio Ruiz (La conquista en el Noroeste 1595-1600), Introducción y notas de Antonio Nakayama, Centro Regional del Noroeste, INAH, México, 1974

Saavedra, Rafael M., "Días santos de los yaquis", El Sol de México, México D.F., 14 de abril de 1973

Sahlins, Marshall, Cultura y razón práctica, Barcelona, Gedisa, 1987

Sapir, Edward, "Symbolism", Encyclopedia of the Social Sciences, New York, Macmillan, Free, vol. XIV, 1968

Schechner, Richard "Waehma: Space, Time, Identity, and Theater at New Pascua, Arizona" en Crumrine, Nye Ross y R. B. Spicer eds., Lent and Holy Week in Northwest Mexico and Southwest United States, Lanhaus, Maryland, University Press of America, en prensa

Schechner, Richard and Willa Appel editors, By means of performance, Intercultural studies of Theatre and Ritual, Cambridge University Press, Cambridge, 1990

Schweder, Richard A., "La rebelión romántica de la antropología contra el iluminismo, o el pensamiento es más que razón y evidencia" en Cliford Geertz et.al. El surgimiento de la antropologia posmoderna, Compilación Carlos Reynoso, Gedisa, México, 1991, págs. 78113

Sèrres, Michel, Eclaircissementes: cinq entrétiens avec Bruno Latour, Paris, F. Bourin, 1992

Hermès II: l'interference, Collection Critique, Paris, Minuit, 1992

Signorini, Italo y Alessandro Lupo, Los tres ejes de la vida. Almas, cuerpo, enfermedad entre los nahuas de la Sierra de Puebla, Biblioteca Universidad Veracruzana, Xalapa, 1989

Simeon, Rémi, Diccionario de la lengua nahuatl o mexicana, Siglo XXI editores, México, 1991

Skorupski, John, Simbolo y teoria, Premia editora, México, 1985

Snyder, Allegra, "Levels of Event Patterns: Theoretical Models Applied to the Yaqui 
Easter Ceremonies" en The Dance Event: $A$ Complex Cultural Phenomenon, edited by Tort, Lisbeth, Copenhaguen \& CDM Study Group on Ethnochoreology, 1989, págs. 1-20

Spicer, Edward H., "El problema yaqui", América indígena, núm.. 8, 1945

Potam: A Yaqui Village in Sonora, American Anthropological Association, Menasha, Wisconsin, 1954

"Social structure and cultural process in Yaqui religious acculturation", American Anthropologist, vol. 60, 1958

Cycles of Conquest: The Impact of Spain, Mexico, and the United States on the Indians of the Southwest, 1533-1960, University of Arizona Press, Tucson, 1962

"Apuntes sobre el tipo de religión de los yuto-aztecas centrales", Actas del XXXV Congreso Internacional de Americanistas, México D.F., Instituto Indigenista Interamericano, 1964

"La danza yaqui del venado en la cultura mexicana", América indigena, 25, págs. 119-39, 1965

"The Yaqui and Mayo", Handbook of Middle American Indians, vol. 3, University of Texas Press, Austin, 1969, págs. 830-844

The Yaquis: A Cultural History, University of Arizona Press, Tucson, 1980

"Yaqui", Handbook of North American Indians, vol. 10, Smithsonian Institution, Washington D.C., 1983, págs. 250-260

Pascua: A Yaqui Village in Arizona, University of Arizona Press, Tucson, 1984

Los Yaquis. Historia de una cultura, traducción de Stella Mastrangello, UNAM, México, 1994

Spicer, Edward H. and Rosamond B. Spicer, field notes, 1936-37

Spicer, Rosamond B., "Yaqui Holy Week: Potam, Rio Yaqui, and Pascua, Arizona, Compared" en Crumrine, Nye Ross y R. B. Spicer eds., Lent and Holy Week in Northwest Mexico and Southwest United States, Lanhaus, Maryland, University Press of America, en prensa

Sperber, Dan, El simbolismo en general, Anthropos, Barcelona, 1988

On Anthropological Knowledge. Three Essays, Cambridge Univerisity Press, Cambridge, 1985

Tambiah Stanley J., Magic, Science, Religion and the Scope of Rationality, Cambridge University Press, 1990

Toor, Frances, A treasury of Mexican Folkways, Crown Publishers, New York, 1947

Troncoso, Francisco P., Las guerras con las tribus yaqui y mayo, edición facsimilar, Instituto Nacional Indigenista, México, 1977

Turner, Victor W., "La clasificación de colores en el ritual ndembu: un problema de clasificación primitiva" en La selva de los símbolos, Siglo XXI editores, Madrid, 1980, págs. 65-102

The ritual process. Structure and Anti-Structure, University of Chicago, Aldine Publishing 
Company, 1974

Dramas, fields and metaphors. Symbolic Action in Human Society, New York, Cornell University Press, 1974

Turner, Victor W. y E. Bruner, The Anthropology of Experience, University of Illinois, Urbana, Illinois, 1986

Tyler, Stephen, Cognitive Anthropology, New York, Holt Rinehart and Winston, 1969 The said and the unsaid, New York, Academic Press, 1978

Tylor, Edward B., Primitive Culture, London, John Murray \& Co., 1903

Valencia Juillerat, Mauro E. y Pablo Wong González (directores), Evaluación y diagnóstico del estado de nutrición de la Tribu Yaqui, Reporte técnico, Centro de Investigación en Alimentación y Desarrollo A.C., Hermosillo, Son., enero 1995

van Gennep, Arnold, Les rites de passage. Un étude systematique des rites..., Librairie Critique Emile Nourry, Paris, 1909

La formación de las leyendas, Presentación de Ramona Violant, Facsímil de la edición de 1914, Barcelona, Editorial Alta Fulla, 1982

Varela, Leticia, "La cosmología indígena sonorense en la danza del venado", Memoria del VIII Simposio de Historia de Sonora, Universidad de Sonora, Hermosillo, 1983

La música en la vida de los Yaquis, Gobierno del Estado de Sonora y la Secretaría de Fomento Educativo y Cultural, 1982

Vázquez Valenzuela, Antolín, La danza del pájaro, Secretaría de Educación Pública, Dirección General de Culturas Populares, Hermosillo, 1985

Villalpando, Elisa C., "Las culturas arqueológicas del desierto sonorense" en Gutiérrez y Gutiérrez coords., El Noroeste de México. Sus culturas étnicas, Museo Nacional de Antropología, México, 1991

Viñas, Moisés, Indice cronológico del cine mexicano 1896-1992, Dirección General de Actividades Cinematográficas, UNAM, México, 1992

Voss, F., On the Periphery of Nineteenth-Century Mexico. Sonora and Sinaloa 1810-1877, Tucson, university of Arizona Press, 1982

Wilder, C.S., The Yaqui Deer Dance: A Study in Cultural Change, Master's thesis, University of Arizona, Tucson, 1940

Winch, Peter, "Para comprender a una sociedad primitiva", Alteridades, año 1, núm. 1, 1991, págs. 82-101 
Wittgenstein, Ludwig, Sobre la certeza, Gedisa, Barcelona, 1988.

Zedillo Ponce de León, Ernesto, Establecer una nueva relación entre el estado mexicano y los pueblos y las comunidades indígenas, Bácum, Sonora, 10 de enero de 1997, Presidencia de la República, Dirección General de Comunicación Social, 1997

Zeilik, Michael, "Sunwatching and Calendars: a Southwestern-Mesoamerican Contrast in a Distiant, Smoky Mirror" en Johanna Broda, et. al., Arqueoastronomía y etnoastronomía en Mesoamérica, Serie de Historia de la Ciencia y la Tecnología 4, México, Instituto de Investigaciones Históricas, UNAM, págs. 545-556, 1991 